\title{
DIVERSIDADE ISOENZIMÁTICA E MORFOLÓGICA DE INHAME (Dioscorea spp.) COLETADOS EM ROÇAS DE AGRICULTURA TRADICIONAL DO VALE DO RIBEIRA - SP
}

\author{
EDUARDO DE ANDRADE BRESSAN
}

Dissertação apresentada à Escola Superior de Agricultura "Luiz de Queiroz", Universidade de São Paulo, para obtenção do título de Mestre em Ecologia de Agroecossistemas.

PIR A C I C A B A

Estado de São Paulo - Brasil

Julho - 2005 


\section{DIVERSIDADE ISOENZIMÁTICA E MORFOLÓGICA DE INHAME (Dioscorea spp.) COLETADOS EM ROÇAS DE AGRICULTURA TRADICIONAL DO VALE DO RIBEIRA - SP}

\section{EDUARDO DE ANDRADE BRESSAN}

Engenheiro Agrônomo

Orientador: Prof $^{\mathrm{a}}$ Dr $^{\mathrm{a}}$ ELIZABETH ANN VEASEY

Dissertação apresentada à Escola Superior de Agricultura "Luiz de Queiroz", Universidade de São Paulo, para obtenção do título de Mestre Ecologia de Agroecossistemas.

PIR A C I C A B A

Estado de São Paulo - Brasil

Julho - 2005 
Dados Internacionais de Catalogação na Publicação (CIP) DIVISÃO DE BIBLIOTECA E DOCUMENTAÇÃO - ESALQ/USP

Bressan, Eduardo de Andrade

Diversidade isoenzimática e morfológica de inhame (Dioscorea spp.) coletados em roças de agricultura tradicional do Vale do Ribeira - SP / Eduardo de Andrade Bressan. - - Piracicaba, 2005.

172 p. : il.

Dissertação (Mestrado) - - Escola Superior de Agricultura Luiz de Queiroz, 2005. Bibliografia.

1. Agricultura tradicional 2. Áreas de conservação 3. Diversidade genética 4. Inhame 5. Isoenzimas 6. Morfologia vegetal 7. Vale do Ribeira I. Título

CDD 635.23

"Permitida a cópia total ou parcial deste documento, desde que citada a fonte - O autor" 
Aos meus avós Agnello Villas Bôas de Andrade e Maria Ignez Rocha de Andrade (vó Bebé) com todo meu amor pelo grande exemplo de vida, carinho e dedicação e a Artemira Villas Boas de Andrade (tia Mira) que também fez parte desta história.

\section{DEDICO}

À minha mãe Maria José Rocha de Andrade, meus tios Lívia Rocha de Andrade e José Roberto e aos meus irmãos (Gustavo, Thomas, "Silvana" e "Tâmara") ao apoio incondicional em todos os momentos da minha vida.

E em especial a Sofia e ao pequeno Raul pelos momentos de alegria, carinho e apoio durante esta caminhada, pois sem este apoio o trabalho não seria realizado!

\section{OFEREÇO}




\section{AGRADECIMENTOS}

Essa dissertação é fruto de intenso trabalho de campo e laboratório que sem a ajuda de várias pessoas não seria possível concretizá-la com sucesso. Desta forma, desejo agradecer as pessoas que direta e indiretamente contribuíram para este sonho, não só meu, mas de diversas pessoas como o Prof. Dr. Paulo Sodero Martins (in memorian) e de todos os seus discípulos da Genética Ecológica. Assim agradeço:

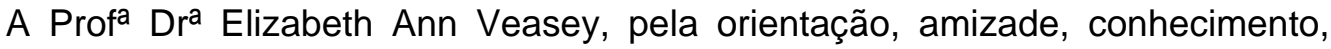
apoio e por acreditar no meu trabalho;

A Dra Maria Imaculada Zucchi pelo apoio e dedicação nas fases finais do trabalho. Obrigado, pela sua ajuda inestimável e por sua orientação extra-oficial durante a realização deste trabalho;

Aos 91 agricultores tradicionais do Vale do Ribeira que direta e indiretamente participaram desta pesquisa;

À toda equipe do projeto "Coleta, uso e caracterização da diversidade genética de germoplasma de batata-doce (Ipomoea batatas L. Lam.) e cará (Dioscorea spp.) em roças de agricultura tradicional do Vale do Ribeira, SP, Brasil";

Ao Prof. Dr. Giancarlo Conde Xavier de Oliveira, pela orientação, atenção, amizade e pela estrutura oferecida nos momentos de dificuldade;

Ao Prof. Dr. Roland Vencovsky, pelas sugestões e críticas que muito contribuíram para a finalização desta obra. Obrigado pela atenção dispensada mesmo nos horários de descanso;

Ao Prof. Dr. Paulo César Tavares de Melo do Departamento de Produção Vegetal, pela orientação, conhecimentos transmitidos, sugestões e pelos materiais cedidos para o banco de germoplasma;

Ao Prof. Dr. Márcio de Castro Silva Filho e ao pessoal do Laboratório de Biologia Molecular de Plantas em especial ao técnico de laboratório Rafael Colombi, 
pelo empréstimo da centrífuga refrigerada que foi um equipamento indispensável à realização da pesquisa;

Ao Prof. Dr. Lee Tseng Sheng Gerald e a bióloga Vitória A. Schmidt da Universidade Federal de São Carlos, pela amizade, apoio e estímulo que fizeram eu chegar até aqui;

À tia Lurdinha, Sr. Nilo, D. Ruth, Raquel, Ricardo e José Luiz R. de Andrade pelo apoio e estímulo;

À secretária Regina Celis Telles de Freitas do programa de pós-graduação Ecologia de Agroecossistemas - Interunidades, que muito apoiou a realização deste trabalho;

Aos colegas de laboratório Marcelo, Rainério, Inez, Fábio, Kayo, Patrícia, Mariana, Jurema, Marcos (português), Eva e Marinês do Laboratório de Ecologia Evolutiva e Genética Aplicada, onde desenvolvi este trabalho, pela amizade, convívio e ajuda;

Ao estagiário Thiago Briner Neto, do curso de Engenharia Agronômica da ESALQ/USP, pelo auxílio durante as avaliações morfológicas do banco de germoplasma;

Ao técnico de laboratório Ronaldo José Rabello pelo auxílio inestimável durante as viagens de coletas e pelos ensinamentos da técnica de eletroforese de isoenzima em gel de amido;

Ao técnico de laboratório Domingos de Sávio Amaral pelo auxílio durante o plantio, condução e colheita do banco de germoplasma de Dioscorea spp.;

Ao Departamento de Genética da ESALQ/USP e a todos os seus professores pelos conhecimentos transmitidos. Aos funcionários em especial: Carlos Roberto Macedônio, Miguel José Bettiol Neto, Vicente de Lábio, Reginaldo de Toledo Lara, Judas Tadeu Chinelatto, Haroldo Fernando Baltazar, Cláudio Roberto Segatelli, Aparecido da Silva, Antonio Norberto Stabelin e Fernando Leopoldino;

À CAPES, pela concessão da bolsa de estudo e ao Programa BIOTA/FAPESP pelo apoio financeiro para a realização desta pesquisa. 


\section{SUMÁRIO}

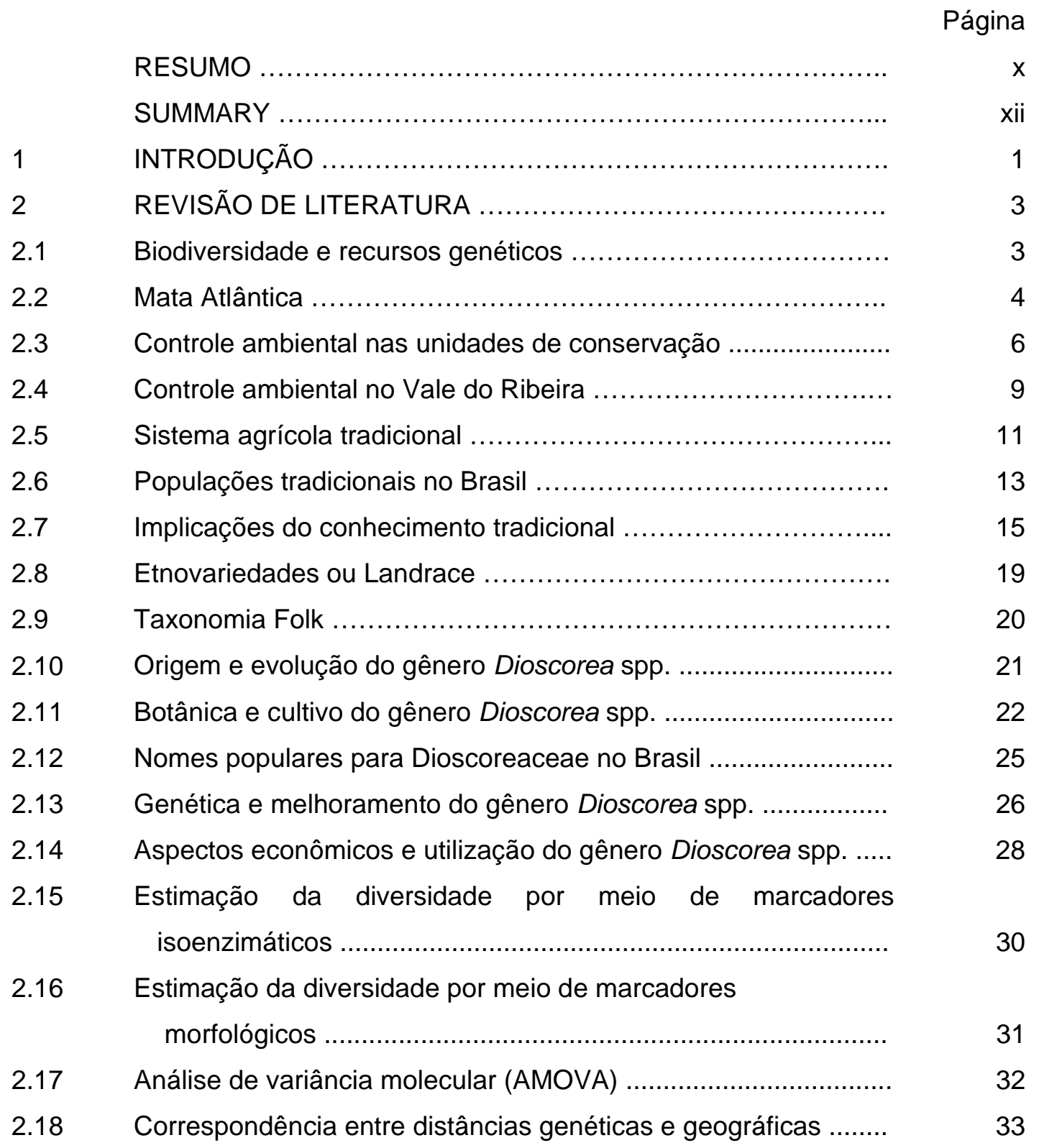


COLETA DE GERMOPLASMA DE INHAME (Dioscorea spp.) EM ROÇAS E QUINTAIS DE AGRICULTORES TRADICIONAIS DO VALE DO RIBEIRA, SÃO PAULO, BRASIL

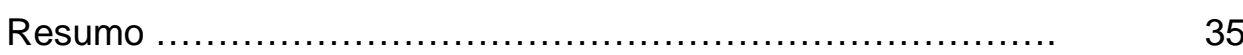

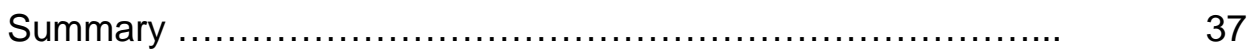

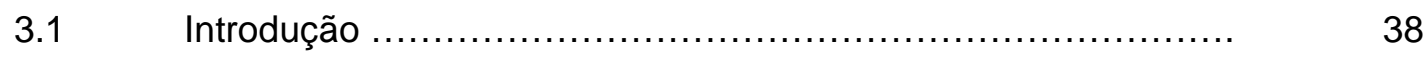

3.2 Material e Métodos ........................................ 40

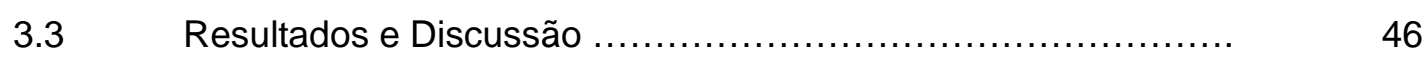

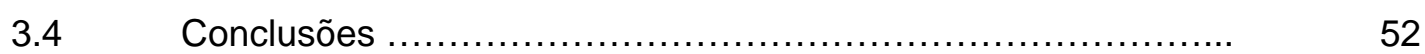

4 DIVERSIDADE ISOENZIMÁTICA E MORFOLÓGICA DE Dioscorea trifida EM ROÇAS DE AGRICULTURA TRADICIONAL DO VALE DO RIBEIRA - SP ................ 53

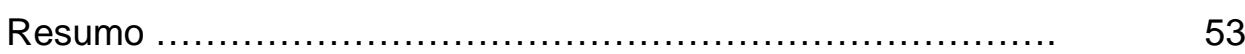

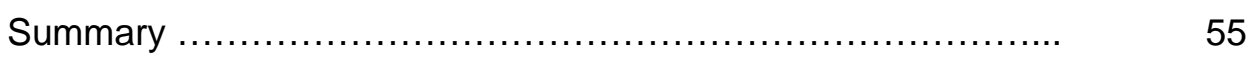

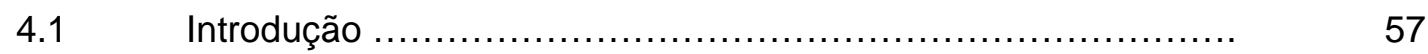

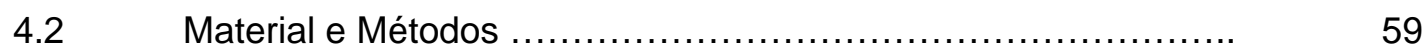

4.2.1 Análise isoenzimática ..................................... 60

4.2.1.1 Extração de enzimas ......................................... 61

4.2.1.2 Preparação dos géis ....................................... 63

4.2.1.3 Composição dos tampões ....................................... 64

4.2.1.4 Avaliação dos sistemas isoenzimáticos ............................ 66

4.2.1.5 Revelação das enzimas ........................................ 67

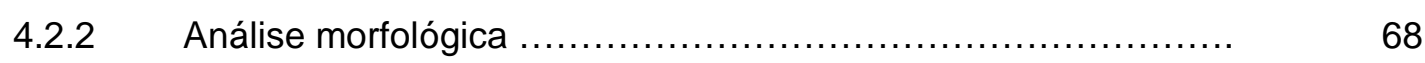

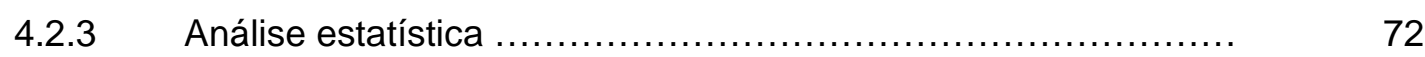

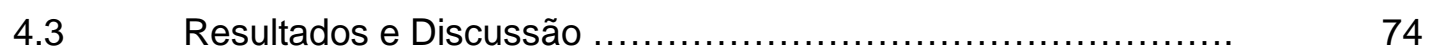

4.3.1 Avaliação isoenzimática ..................................... 74

4.3.2 Avaliação morfológica ......................................... 79

4.3.3 Correlação entre estimativas isoenzimáticas e morfológicas ...... 85

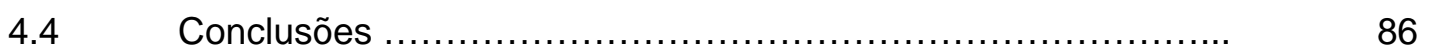


DIVERSIDADE ISOENZIMÁTICA E MORFOLÓGICA DE Dioscorea bulbifera EM ROÇAS DE AGRICULTURA TRADICIONAL DO VALE DO RIBEIRA - SP ................. 88

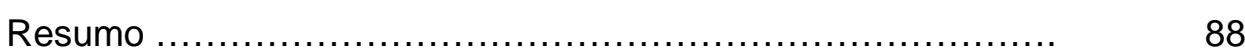

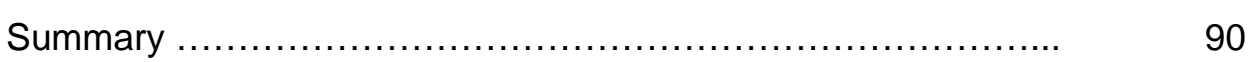

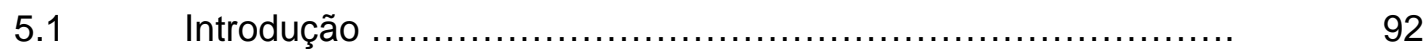

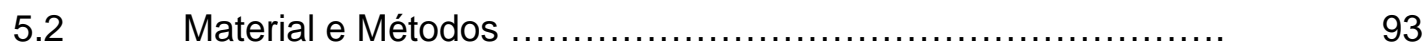

5.2.1 Análise isoenzimática ..................................... 95

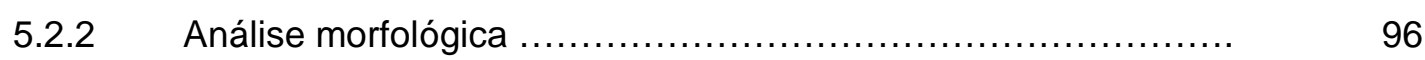

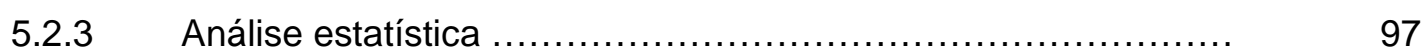

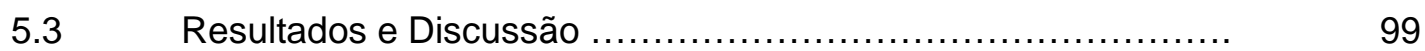

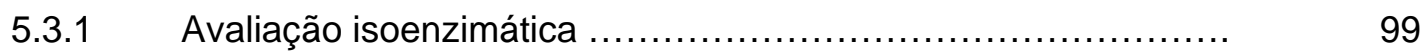

5.3.2 Avaliação morfológica .......................................... 103

5.3.3 Correlação entre estimativas isoenzimáticas e morfológicas ...... 107

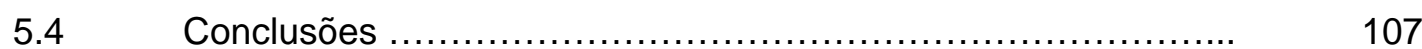

6 DIVERSIDADE ISOENZIMÁTICA E MORFOLÓGICA DE Dioscorea alata EM ROÇAS DE AGRICULTURA TRADICIONAL DO VALE DO RIBEIRA - SP ................. 108

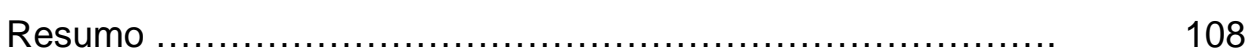

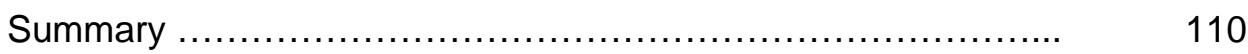

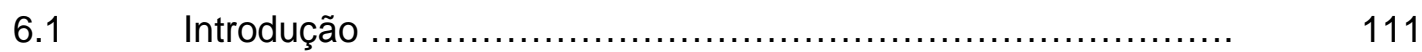

$6.2 \quad$ Material e Métodos ........................................... 112

6.2.1 Análise isoenzimática ...................................... 113

6.2.2 Análise morfológica .......................................... 114

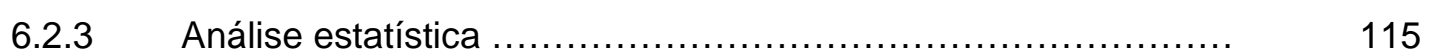

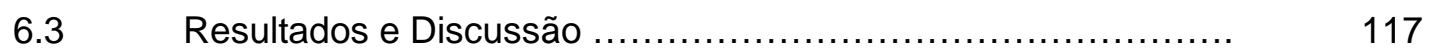

6.3.1 Avaliação isoenzimática ..................................... 117

6.3.2 Avaliação morfológica .......................................... 121

6.3.3 Correlação entre estimativas isoenzimáticas e morfológicas ...... 125

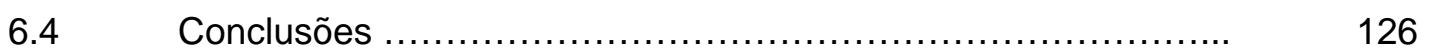


DIVERSIDADE ISOENZIMÁTICA E MORFOLÓGICA DE Dioscorea cayenensis EM ROÇAS DE AGRICULTURA TRADICIONAL DO VALE DO RIBEIRA - SP

Resumo

Summary

7.1 Introdução

7.2 Material e Métodos

7.2.1 Análise isoenzimática

7.2.2 Análise morfológica

7.2.3 Análise estatística

7.3 Resultados e Discussão

7.3.1 Avaliação isoenzimática

7.3.2 Avaliação morfológica

7.3.3 Correlação entre estimativas isoenzimáticas e morfológicas ....... 


\title{
DIVERSIDADE ISOENZIMÁTICA E MORFOLÓGICA DE INHAME (Dioscorea spp.) COLETADOS EM ROÇAS DE AGRICULTURA TRADICIONAL DO VALE DO RIBEIRA - SP
}

\author{
Autor: EDUARDO DE ANDRADE BRESSAN \\ Orientador: Prof ${ }^{\mathrm{a}}$. Dr ${ }^{\mathrm{a}}$. ELIZABETH ANN VEASEY
}

\section{RESUMO}

Os agricultores tradicionais da região sul do Estado de São Paulo têm se mostrado mantenedores de um grande repositório de diversidade genética e de conhecimento a respeito das peculiaridades de manejo desta diversidade. A cultura do inhame (Dioscorea spp.) é mantida e manejada nesta região em roças que empregam o sistema de coivara. Esta pesquisa teve como objetivos coletar etnovariedades de inhame nas roças/quintais dos agricultores tradicionais do Vale do Ribeira, visando manter um banco de conservação ex situ na Escola Superior de Agricultura "Luiz de Queiroz" em Piracicaba - SP e estimar a diversidade morfológica e isoenzimática de inhames mantidos em sistemas agrícolas autóctones. Visitou-se 91 agricultores que ainda praticam a agricultura tradicional no Vale do Ribeira dos quais 45 cultivavam o inhame. Desses, 31\% o cultivavam em roças itinerantes e 69\% em quintais. Quatro espécies de inhame foram encontradas: $D$. trifida, $D$. bulbifera, $D$. alata e $D$. cayenensis. As etnovariedades foram caracterizadas por meio de marcadores isoenzimáticos, utilizando géis de poliacrilamida (seis sistemas) e amido (um sistema), e por marcadores morfológicos, num total de 24 caracteres. Para ambos os marcadores, foram calculados o índice de similaridade de Jaccard entre pares de indivíduos. Análises de agrupamento foram realizadas para variedades, roças e comunidades, a partir dos índices de similaridade de Jaccard e do critério aglomerativo UPGMA. Outro parâmetro analisado foi a correlação entre as matrizes de distância genética (isoenzimática e morfológica) e geográfica pela correlação de Pearson (r) e 
teste de Mantel, para verificar se a diversidade genética encontrava-se estruturada no espaço. Além disso, realizou-se a análise de variância molecular (AMOVA) para se verificar a distribuição da variabilidade nos diferentes níveis hierárquicos: entre e dentro das unidades evolutivas biológicas (roças) e culturais (comunidades). Os resultados revelaram que os agricultores tradicionais do Vale do Ribeira manejam grande diversidade genética, tanto isoenzimática como morfológica, em suas roças e que essa diversidade não está estruturada no espaço para todas as espécies cultivadas. A AMOVA indicou que para as espécies $D$. trifida, $D$. bulbifera e $D$. cayenensis a distribuição da variabilidade concentra-se entre roças dentro de comunidades, enquanto que para $D$. alata concentra-se dentro de roças para os marcadores isoenzimáticos. Para os marcadores morfológicos, a maior parte da variabilidade concentra-se entre roças dentro de comunidades para $D$. bulbifera e $D$. cayenensis e dentro de roças para $D$. alata e $D$. trifida, ressaltando-se a seleção humana para os aspectos visuais. Conclui-se que os agricultores tradicionais do Vale do Ribeira cultivam grande diversidade de etnovariedades e espécies de Dioscorea, além de possuírem grande conhecimento a respeito das peculiaridades de manejo desta cultura. Contudo, as pressões que esses agricultores estão sofrendo poderá no futuro provocar perda de diversidade genética. Recomenda-se novos estudos na região para verificar os danos causados por essas pressões aos processos evolutivos presentes nas roças dos agricultores tradicionais do Vale do Ribeira. 
ISOENZYMATIC AND MORPHOLOGICAL DIVERSITY OF YAMS (Dioscorea spp.) COLLECTED IN SWIDDENS OF TRADITIONAL AGRICULTURE OF THE RIBEIRA RIVER VALLEY - SP

\author{
Author: EDUARDO DE ANDRADE BRESSAN \\ Adviser: Profa. Dra. ELIZABETH ANN VEASEY
}

\title{
SUMMARY
}

Traditional agriculturists of the south region of the State of São Paulo have been maintainers of a great repository of genetic diversity and knowledge regarding the management peculiarities of this diversity. The yam (Dioscorea spp.) culture is maintained and cultivated in this region in swiddens that use the system of "coivara". This research had the objective of collecting ethnovarieties of yam in the swiddens/home gardens of the traditional agriculturists of the Ribeira River Valley, aiming at maintaining a germplasm bank for ex situ conservation at the Escola Superior de Agricultura "Luiz de Queiroz" in Piracicaba, SP and estimating the morphological and isoenzymatic diversity of yams kept in authoctone agricultural systems. Ninety-one agriculturists that still practice traditional agriculture were visited in the Ribeira River Valley, of which 45 cultivated yam. Of these, 31\% cultivated this crop on itinerant swiddens and $69 \%$ in home gardens. Four yam species were found: $D$. trifida, $D$. bulbifera, $D$. cayenensis and $D$. alata. The ethnovarieties of each species were characterized with isoenzymatic markers, using polyacrilamide gels (six systems) and starch gels (one system), and with morphological markers, in a total of 24 characters. For both markers, the Jaccard similarity indices between pairs of individuals were obtained. Cluster analyses were conducted for varieties, swiddens and communities using the Jaccard similarity indices and the UPGMA method. Another parameter analyzed was the correlation between the genetic distances (isoenzymatic and 
morphological) and the geographic distance matrices using the Pearson correlation and Mantel test, to verify if the genetic diversity was structured in space. An analysis of molecular variance (AMOVA) was carried out to verify the distribution of the variability in the different hierarchic levels: within and between the biological evolutionary units (swiddens) and cultural units (communities). Results showed that the traditional agriculturists of the Ribeira River Valley maintain a great genetic diversity, both isoenzymatic and morphological, in their swiddens and home gardens, and that this diversity is not structured in space for the four species cultivated. The AMOVA results for $D$. trifida, $D$. bulbifera and $D$. cayenensis showed that the isoenzymatic variability is mainly concentrated among swiddens within communities, and within swiddens for $D$. alata. For the morphological markers, where visual aspects are an important issue in human selection, most of the variability is concentrated among swiddens within communities for $D$. bulbifera and $D$. cayenensis, and within swiddens for $D$. alata and $D$. trifida. It is concluded that the traditional agriculturists of the Ribeira River Valley cultivate great diversity of ethnovarieties and species of Dioscorea, also possessing great knowledge concerning the management peculiarities of this crop. However, the pressures that these agriculturists are suffering may cause a loss of genetic diversity in the future. Further studies are recommended in this region to verity the damage caused by these pressures in the evolutionary processes that occur in the swiddens of the Ribeira River Valley traditional agriculturists. 


\section{INTRODUÇÃO}

Nas últimas décadas vêm se intensificando os estudos genéticos em populações de plantas nativas e cultivadas visando verificar sua abundância, distribuição, composição e potencialidades para a industria alimentícia e farmacêutica.

No Brasil os biomas como a Mata Atlântica, Pantanal, Caatinga, Cerrados e Floresta Amazônica são verdadeiros bancos naturais de recursos genéticos. Parte desses recursos genéticos são conservados in situ pelos agricultores tradicionais que muitas vezes promovem o aumento da variabilidade genética e, conseqüentemente, a redução dos riscos de extinção das espécies cultivadas e semi-domesticadas.

Entretanto, existe uma preocupação crescente com as estratégias que permitam a manutenção da diversidade genética in situ, por meio dos agricultores tradicionais e populações indígenas que estão sofrendo com a ação antropogênica de caçadores, madeireiros e grileiros. Um bom exemplo é a região sul do Estado de São Paulo (Vale do Ribeira), onde podemos encontrar corredores semi-intactos de Mata Atlântica coexistindo com a agricultura tradicional. Nessa região os agricultores têm se mostrado como mantenedores e geradores de diversidade genética de plantas cultivadas e nativas, além de serem detentores do conhecimento a respeito das peculiaridades de manejo desta diversidade, permitindo, desta forma, a continuidade de processos evolutivos inerentes à relação entre o homem e as plantas cultivadas. Apesar disso, o risco de perda desta diversidade genética também é grande devido às múltiplas influências que têm incentivado os agricultores a abandonarem a atividade agrícola, como o desenvolvimento do turismo, atividades imobiliárias e madeireiras na região.

No início da década de 90, o Laboratório de Genética Ecológica, do Departamento de Genética da Escola Superior de Agricultura "Luiz de Queiroz" sob o comando do Prof. Dr. Paulo Sodero Martins (in memorian), atualmente denominado Laboratório de Ecologia Evolutiva e Genética Aplicada (LEEGA), iniciou um programa 
de pesquisas na área de evolução de plantas cultivadas com ênfase em plantas com propagação vegetativa nas terras baixas da América do Sul. Este estudo estabeleceu um modelo que explicita a dinâmica evolutiva da cultura da mandioca (Manihot esculenta Crantz) destacando-se os trabalhos de Cury (1993, 1998), Peroni (1998), Faraldo (1994, 1999), Silva (2000), Sambatti et al. (2001) e Silva et al. (2003), todos desenvolvidos em áreas de agricultura autóctone no litoral de São Paulo e em diversas regiões da Amazônia.

Este estudo visa estender as hipóteses do modelo de dinâmica evolutiva proposto para mandioca para espécies de reprodução vegetativa como o inhame (Dioscorea spp.). Esta cultura, a exemplo da mandioca, é mantida e manejada pelos agricultores tradicionais e povos indígenas do Vale do Ribeira, sendo uma das mais importantes em termos de número de variedades, depois da mandioca. Portanto, o presente trabalho teve como objetivo avaliar a diversidade genética, por meio de marcadores morfológicos e isoenzimáticos, de variedades e espécies de inhame (Dioscorea spp.), além de verificar de que forma esta diversidade se distribui nos diferentes níveis de organização como roças e comunidades do Vale do Ribeira.

Desta forma, o estudo foi baseado nas seguintes hipóteses:

- Existe grande variabilidade genética para as espécies e variedades de inhame cultivadas por agricultores tradicionais do Vale do Ribeira, São Paulo, Brasil;

- A legislação florestal vigente na Floresta Atlântica estaria promovendo uma redução na diversidade genética nas espécies de Dioscorea spp. cultivadas no Vale do Ribeira;

- Existe uma correlação genética e geográfica devido ao sistema de troca de materiais entre os agricultores;

- Os marcadores isoenzimáticos são mais informativos quando comparados com os marcadores morfológicos. 


\section{REVISÃO DE LITERATURA}

\subsection{Biodiversidade e recursos genéticos}

A biodiversidade pode ser conceituada como a variedade de vida no planeta, incluindo a variabilidade genética dentro das populações e espécies (flora, fauna e microrganismos), além das funções ecológicas desempenhadas por estes organismos nos ecossistemas. Portanto, a biodiversidade é uma das propriedades fundamentais da natureza, responsável pelo equilíbrio e estabilidade dos ecossistemas, além de ser fonte de imenso potencial de uso econômico (Ministério do Meio Ambiente, 2004).

Diversos segmentos da sociedade, em especial a comunidade científica, vêm alertando para a perda da diversidade biológica em todo o mundo e em particular nas regiões tropicais devido a fatores sociais, econômicos, culturais e científicos (Ministério do Meio Ambiente, 2004). Na América Latina, países como o Brasil, Colômbia, Venezuela, México, Equador e Peru são considerados como detentores de grande biodiversidade. Nos outros continentes destacam-se a África (Zaire e Madagascar), a Ásia (China, Índia, Malásia e Indonésia) e na Oceania, a Austrália (Morales \& Valois, 2000).

No mundo o Brasil é o país possuidor da maior megadiversidade biológica, pois se estima que $20 \%$ de toda diversidade existente no planeta possa estar nas florestas deste país. Além disso, o Brasil possui a maior parte de suas florestas intactas. A Mata Atlântica, o Pantanal, o Semi-Árido, os Cerrados e a Amazônia são verdadeiros bancos naturais de recursos genéticos (Morales \& Valois, 2000).

Porém, a destruição e fragmentação das florestas anunciam a extinção de muitas espécies. Em uma região rica em espécies endêmicas o processo de isolamento contínuo resulta no empobrecimento irreversível da biodiversidade. No caso brasileiro os biomas como a Mata Atlântica e o Cerrado enfrentam essa realidade. Os 
Andes tropicais, Madagascar, Filipinas, dentre outras regiões, lidam com o mesmo desafio (Fonseca, 2004).

No caso dos recursos genéticos podemos considerar a variabilidade de plantas, animais e microrganismos integrantes da biodiversidade como base biológica para a geração das tecnologias nos programas de melhoramento genético, biotecnologia e outras atividades afins que tem previsão de uso atual ou potencial (Queiróz, 2004).

O pioneirismo do botânico russo Nikolai I. Vavilov no início do século XX representou um marco inicial nos trabalhos com recursos genéticos vegetais, pois ele foi o primeiro a compreender a importância e os benefícios potenciais a serem alcançados com as coletas de germoplasmas ao redor do mundo e pela organização dessas amostras em forma de coleções (Nass, 2001).

Esses recursos genéticos apresentam valor inestimável independentemente da forma em que possam ser aproveitados pela genética, pois o germoplasma é o material que constitui a base física da herança e que é transmitida de uma geração para outra (Querol, 1993; Nass, 2001). Esses recursos são estudados em várias etapas bem definidas como a coleta, multiplicação, preservação/conservação, avaliação/caracterização e usos (Hawkes, 1982). Em nível internacional, o International Plant Genetic Resources Institute (IPGRI) vem concentrando esforços para a sistematização dos estudos dos recursos genéticos, além de desenvolver a consciência para a importância dos mesmos, a fim de que seja conservada e mantida para as gerações atuais e futuras uma grande quantidade de acessos de muitas espécies (Queiróz, 2004).

\subsection{Mata Atlântica}

A Floresta Atlântica (Mata Atlântica) formava, originalmente, uma área contínua com mais de $1.000 .000 \mathrm{~km}^{2}$, incluindo várias formações florestais e ecossistemas associados, como a Floresta Ombrófila Densa Atlântica, Floresta Ombrófila Mista, Floresta Ombrófila Aberta, Floresta Ombrófila Estacional Decidual, Floresta Ombrófila Estacional Semidecidual, manguezais, restingas, campos de altitude e brejos interioranos segundo o Decreto Lei $n^{\circ} 750$ de 10 de fevereiro de 1993 (Fundação SOS Mata Atlântica, 1997). É um ecossistema composto de numerosas formas de vida que interagem entre si e que resultam num ambiente equilibrado, porém este patrimônio 
natural é um dos biomas mais ameaçados do planeta. Na década de 90, existia cerca de $8 \%$ dessa cobertura florestal no país, em sua maioria na forma de fragmentos com formações florestais secundárias (Fundação SOS Mata Atlântica, 1997). Portanto, a conservação da Floresta Tropical Atlântica envolve necessariamente alternativas de uso que permitam retorno econômico, promovendo desta forma, o sustento das populações tradicionais e a manutenção do ecossistema (Mariot et al., 2000). Várias espécies nativas da Floresta Tropical Atlântica (Mata Atlântica) de valor alimentício e medicinal têm sido intensamente exploradas pelos agricultores tradicionais como fonte de recursos econômicos. A manutenção da diversidade biológica tornou-se em anos mais recentes um dos objetivos mais importantes da conservação, porém esta diversidade não se restringe a um conceito pertencente ao mundo natural, mas também cultural e social, pois as espécies são objetos de conhecimento, domesticação, uso, fonte de inspiração para mitos e rituais das sociedades tradicionais. No entanto, muitas vezes a variabilidade é entendida como produto da própria natureza, sem a intervenção humana (Diegues, 1996).

O Vale do Ribeira abriga a maior extensão ainda conservada de Mata Atlântica, apresentando grande diversidade biológica e genética de espécies e ecossistemas. Além disso, a região apresenta grande diversidade cultural, constituída por culturas indígenas, como os guaranis e as comunidades tradicionais não indígenas representadas pelos caiçaras, quilombolas, caboclos ribeirinhos e imigrantes japoneses e americanos (Diegues, 2000b).

Apesar do grande patrimônio cultural essas populações têm sido marginalizadas pelas políticas públicas e pela legislação ambiental. Porém, a preocupação com as "populações tradicionais" que vivem no Vale do Ribeira é relativamente recente, pois estudos indicam que essas populações são os "novos agentes" na área da conservação, em virtude do grande conhecimento acumulado sobre a biodiversidade, pelas práticas de manejo e por seus movimentos de defesa de seus modelos de vida (Di Stati et al., 2000). 


\subsection{Controle ambiental nas unidades de conservação}

A criação de unidades de conservação (parques e reservas) tem sido um dos principais elementos de estratégias para a conservação da natureza em todo o mundo e em particular nos países do Terceiro Mundo. O objetivo é proteger os espaços com atributos ecológicos importantes. A concepção dessas áreas protegidas provém do século passado, tendo sido criadas primeiramente nos Estados Unidos, a fim de proteger a vida selvagem (wilderness) ameaçada pela civilização urbano-industrial, destruidora da natureza segundo os teóricos Thoreau e Marsh (Diegues, 1996).

Desta forma, em $1^{\circ}$ de março de 1872 foi criado o Parque Nacional de Yellowstone, onde a natureza deveria ser preservada e proibida de ser colonizada, vendida e ocupada, sendo permitido a utilização da área para educação e recreação. $O$ Canadá criou sua primeira unidade de conservação (UC) em 1885, seguido da Nova Zelândia em 1894 e da Austrália em 1898. No Brasil, a constituição de 1937 definiu as responsabilidades da União em proteger as belezas naturais e monumentos de valor histórico no seu artigo 134. A primeira UC criada foi em Itatiaia em 1937 com o objetivo de incentivar a pesquisa científica e oferecer lazer às populações urbanas (Diegues, 2000a).

Este modelo foi transposto dos EUA para países de Terceiro Mundo como o Brasil, onde a situação ecológica, social e cultural é distinta. Nesses países, mesmo nas Florestas Tropicais aparentemente vazias, vivem populações indígenas, ribeirinhas, extrativistas, pescadoras, chamadas de tradicionais. A legislação brasileira que cria as unidades de conservação (parques e reservas) prevê em seus artigos, como nos EUA, a transferência dos moradores dessas áreas, causando uma série de problemas de caráter ético, social, econômico, político e cultural (Diegues, 1996).

A partir dos anos 30, no Brasil, iniciou-se o processo de implantação das áreas naturais protegidas principalmente nos espaços territoriais litorâneos, de mata Tropical Úmida, habitado por populações tradicionais e em 1990 o Brasil contava com 15 tipos de unidades de conservação, englobando cerca de 429 em nível das esferas federal, estadual e municipal, ocupando uma área de 48.720.109 ha. Segundo Ghimire (1993), a atual preocupação mundial para a criação de unidades de conservação se deve a uma combinação de fatores como a rápida degradação das florestas, perda da 
biodiversidade, disponibilidade de fundo internacional para conservação e a possibilidade de renda com o turismo.

Quando uma nova unidade de conservação é criada, ou quando as fronteiras de uma unidade de conservação já existente passam a ser rigidamente controladas, as pessoas podem ter seu acesso negado a um recurso que elas sempre utilizaram e até mesmo preservaram. Para sobreviver, as pessoas podem chegar a violar as normas de preservação das unidades de conservação, resultando em confrontos com os órgãos fiscalizadores (Di Stati et al., 2000).

Para Diegues \& Arruda (2001), as unidades de conservação acabam representando um modelo hipotético de mundo natural primitivo, intocado, mesmo que grande parte tenha sido manipulada por populações tradicionais durante dezenas e até centenas de anos sem as depredarem, criando paisagens mistas de florestas manejadas e intocadas. Portanto, a política conservacionista brasileira tem se mostrado equivocada quanto aos seus conceitos, gerando, desta forma, graves problemas ambientais e sociais. Pois, em um ecossistema manejado, algumas espécies podem se extinguir como resultado dessa ação, ainda que o efeito total dessa interferência possa culminar em um aumento real da diversidade ecológica e biológica de um lugar específico ou região. Ballé (1993) cita o caso dos Kaapor, em que o manejo tradicional resultou no aumento de espécies de determinados hábitats, ainda que tal conseqüência não tenha sido buscada intencionalmente. Outros autores como Gómez-Pompa \& Kaus (1992) ressaltam que o conhecimento indígena dos diversos ecossistemas e suas práticas agrícolas resultou em uma maior diversidade de espécies nos ambientes manipulados quando comparados com as florestas consideradas nativas.

A expulsão dos moradores tem contribuído para a degradação dos parques, uma vez que a falta de fiscalização e a ação de indústrias madeireiras e de mineração que exploram ilegalmente os recursos naturais das unidades de conservação tem trazido como conseqüência a perda de biodiversidade. Outro ponto é a falta de avaliação por parte dos governos como no caso da Tailândia e Madagascar onde as populações perderam sua base de subsistência material e cultural. As áreas protegidas brasileiras, em particular os parques nacionais e reservas biológicas estão em crise, pois se encontram invadidas e degradadas (Diegues \& Arruda, 2001). 
Para os defensores do modelo norte-americano de parques sem habitantes, as razões para essas crises estão ligadas a falta de investimentos e fiscalização. Contudo, para os pesquisadores que defendem outras alternativas de conservação, essas dificuldades são inerentes ao modelo atual. Esses pesquisadores centram sua análise na inadequação do conceito de wilderness, como natureza selvagem não domesticada. Partem da constatação que muitas dessas áreas habitadas por populações tradicionais haviam se conservado sob cobertura florestal e com alta biodiversidade em virtude do manejo ligado ao modo de vida dessas populações. A biodiversidade não é um conceito apenas biológico, relativo a diversidade genética de indivíduos, de espécies e de ecossistemas, mas também de resultados de práticas milenares das comunidades tradicionais que domesticam espécies, mantendo e aumentando a diversidade local (Posey, 1987; Gómez-Pompa, 1971; Gómez-Pompa \& Kaus, 1992).

Como os parques nacionais norte americanos foram estabelecidos por razões estéticas e de turismo e não para a proteção da biodiversidade, pode-se dizer que essa ocorreu por casualidade. Também podemos encontrar casos em que a exclusão do homem resultou em perda de biodiversidade. Como exemplo podemos citar os parques de Serengeti e Ngorongoro, no Quênia e na Tanzânia onde as tribos de pastores com atividade de pastoreio e queima de pastagem, permitiram que os rebanhos e os animais selvagens coexistissem, criando uma paisagem que hoje é valorizada pelos conservacionistas. A constituição de parques nacionais e a exclusão de tribos levaram à conversão do pasto em arbusto, com impactos negativos sobre os animais herbívoros, que desempenham papel fundamental para a diversidade biológica da região (Colchester, 1997).

Estudos afirmam que a manutenção e mesmo o aumento da diversidade biológica nas florestas tropicais estão relacionados intimamente com as práticas tradicionais de agricultura itinerante dos povos primitivos (Ballé, 1992; Gómez-Pompa, 1971; Gómez-Pompa \& Kaus, 1992).

A regeneração da floresta úmida parece ser, em parte, conseqüência das atividades do homem primitivo. O resultado do uso de pequenas áreas de terra para a agricultura e seu abandono no pousio é semelhante ao produzido pela destruição ocasional das florestas por causas naturais. Gómez-Pompa (1971) também afirma que alguns pesquisadores descobriram que muitas espécies dominantes das selvas 
primárias do México e América Central são, na verdade, espécies úteis protegidas no passado pelo homem e que a variabilidade induzida pelo homem no meio ambiente das zonas tropicais é um fator que favoreceu de maneira considerável a variabilidade das espécies e provavelmente sua especiação. Posey (1987) afirma que os índios Kayapós brasileiros têm o hábito de transplantar ao lado das espécies domesticadas/ semidomesticadas várias espécies da floresta primária. Os saberes tradicionais podem contribuir para a manutenção da biodiversidade dos ecossistemas sendo muitas vezes resultado de uma coevolução entre as sociedades e seus ambientes naturais (Noorgard, 1994).

A implantação de áreas protegidas na África, Ásia e América Latina, nas primeiras décadas do presente século, começaram a gerar conflitos sociais e culturais sérios com as populações locais. Esses problemas tornaram-se mais sérios a partir da década de 70, quando as comunidades locais/tradicionais começaram a se organizar e a resistir à expulsão ou transferência de seus territórios como dita o modelo preservacionista. Segundo Diegues (2000b), diversos autores em diferentes partes do mundo como Sukumar (1985; 1994), Kothari (1994), Gadgil \& Gunha (1992) na Índia, Adams \& McShane (1992) na África, Amend (1992), Gómez-Pompa \& Kaus (1992), Diegues $(1993 ; 1994)$ analisaram os impactos sociais, ecológicos e culturais sobre regiões de floresta tropical, em diferentes continentes.

\subsection{Controle ambiental no Vale do Ribeira}

No Vale do Ribeira encontramos um dos maiores remanescentes de Mata Atlântica da região Sudeste do Brasil (Fundação SOS Mata Atlântica, 1997). No interior da floresta encontramos agricultores tradicionais praticando a agricultura de coivara.

Três fatores podem influenciar na manutenção dos sistemas agrícolas autóctones na região do Vale do Ribeira como: a questão fundiária; a legislação florestal; e a prática do fogo nos roçados (Felipim et al., 2000).

As legislações vigentes que regulamentam o controle ambiental nas Áreas de Preservação Ambiental (APA's) e nas áreas não abrangidas por estas restringem e/ou limitam o uso e a ocupação da região para a prática da agricultura de coivara. Essas leis e decretos exigem o licenciamento ambiental para atividades potencialmente degradadoras ou que utilizem recursos naturais. Como exemplo podemos citar o 
Código Florestal (lei 4771/65) que regulamenta as atividades que envolvem o uso ou corte de vegetação nativa. O licenciamento ambiental e a fiscalização são exercidos por diversos órgãos ao nível federal, estadual e municipal.

Com relação à questão fundiária, o Código Florestal exige para cada propriedade a averbação de $20 \%$ de Reserva Legal na matrícula do registro do imóvel. Desta forma, grande parte das populações tradicionais que possuem a propriedade formal das terras fica excluída do requerimento da licença ambiental para praticarem a agricultura de corte e queima. Porém, a mesma legislação não exclui os agricultores das penalidades legais durante a abertura de novos roçados (Felipim et al., 2000).

Contudo, o Decreto Federal $750 / 93$ em seu artigo $2^{\circ}$ faz referência às populações tradicionais quanto a exploração seletiva de determinadas espécies nativas da Mata Atlântica como o palmito (Euterpe edulis MART) e a caixeta (Tabebuia cassinoides (Lam.) DC.) desde que estejam vinculadas a autorização do órgão estadual competente. Outro ponto abordado pelo decreto, segundo Felipim et al. (2000), é o corte da vegetação secundária em estágio inicial (capoeirinha) para fins agrícolas, o que devido a baixa fertilidade do solo não traria benefícios aos agricultores tradicionais.

A prática do fogo nos roçados visando a limpeza das áreas, dentre outros benefícios, é tratada como contravenção penal pelo Código Florestal em seu artigo 26. O artigo 27 do mesmo Código proíbe a utilização do fogo em áreas florestais e demais formas de vegetação desde que o poder público considere as peculiaridades locais ou regionais (Brasil, 1965). Já o decreto 2.661/98 regulamenta o artigo 27 do Código Florestal normatizando o uso do fogo em atividades agropastoris e florestais por meio da "queima controlada" que dependerá de autorização prévia do órgão competente.

Desta forma, encontramos todos os fatores supra citados, promovendo a desorganização dos agricultores tradicionais.

Porém, a preocupação com as "populações tradicionais" é relativamente recente no Brasil, pois, essas sociedades desenvolveram formas particulares de manejo dos recursos naturais que não visam diretamente o lucro, mas a reprodução social e cultural. Martins (2001) cita que as populações tradicionais que convivem em ambiente natural e que são responsáveis pela geração e manutenção dos altos níveis de diversidade foram obrigadas a abandonar suas terras de cultivo, pois a legislação 
vigente dificulta a prática da agricultura de subsistência como roçados, pesca e extrativismo vegetal.

\subsection{Sistema agrícola tradicional}

A história das roças tradicionais começa na pré-história e vai sendo modificada pelo homem com a adição de vários componentes ao longo de sua evolução (Martins, 2001). Na época pré-colombiana nem todos os povos indígenas das Américas atingiram a fase agrícola. Na América do Norte foram as tribos Atlânticas as que alcançaram este estágio. Todas as centro-americanas cultivavam o solo, enquanto que na América do Sul a roça tradicional é uma herança dos índios que derrubavam e queimavam as matas fazendo a seguir o plantio por três anos consecutivos (Oliveira et al., 1994). Com a redução da produtividade devido ao empobrecimento do solo, a área é abandonada por um período que varia de três a dez anos, deixando espaço para uma sucessão ecológica visando a recuperação do solo exaurido (Figura 1A). Portanto, o pousio visa recuperar o solo através da ciclagem de nutrientes, pois a capoeira formada captura os nutrientes externos de origem atmosférica e os fixa nos tecidos vivos que são incorporados em uma etapa posterior, através da deposição e decomposição da serrapilheira.
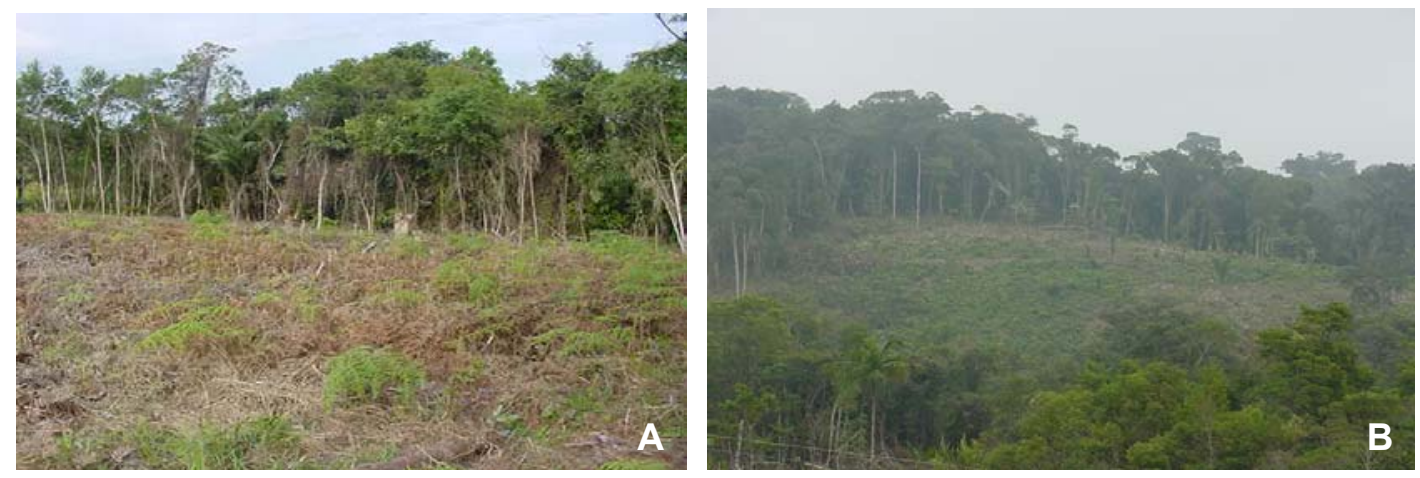

Figura 1 - Roça abandonada devido à acidez do solo (A) e abertura de uma roça de toco no Vale do Ribeira (B)

Quando o agricultor volta a praticar a agricultura em uma área de regeneração, derrubando e incendiando uma capoeira (Figura 1B), os nutrientes estocados na biomassa se dispersam no solo e a acidez é neutralizada pelo alto $\mathrm{pH}$ das cinzas 
assim como a toxicidade do alumínio é reduzida, além de aumentar a concentração de nutrientes no solo (Oliveira et al., 1994; Martins, 2001).

Martins (2001) estudou bancos de sementes de mandioca (Manihot spp.) em uma comunidade Caiçara na Ilha Comprida e um quilombo no Vale do Ribeira. Foram coletadas informações dos agricultores locais e observado o estado de desenvolvimento da capoeira. Cruzando-se os dados constatou-se que após dez ou quinze anos os agricultores voltavam, derrubavam e queimavam a vegetação para reinstalar a roça. A área foi monitorada por três anos. A amplificação da diversidade de espécies está relacionada a um conjunto de mecanismos: a introdução de variedades nas roças e comunidades, invasão de espécies selvagens e arranjamento espacial das plantas. Tudo isso permite a hibridação inter e intra-específica que são mecanismos chaves na amplificação da variabilidade genética. A amplificação da variabilidade genética na roça é auxiliada também por mais dois fatores integrados (Martins, 2001): a biologia das sementes, e o sistema de coivara adotado pela maioria dos Caboclos, Índios e Caiçaras.

Desta forma, as comunidades tradicionais são responsáveis pela manutenção e aumento da biodiversidade das espécies cultivadas por elas (Hanazaki et al., 1996). As roças tradicionais destinam-se a produção de alimentos para subsistência, sendo constante a prática do policultivo. Portanto, a roça dá idéia de um sistema caótico (Figura 2), em que tudo é plantado sem qualquer ordem pré-estabelecida reproduzindo em escala reduzida a diversidade de uma floresta (Oliveira et al., 1994).

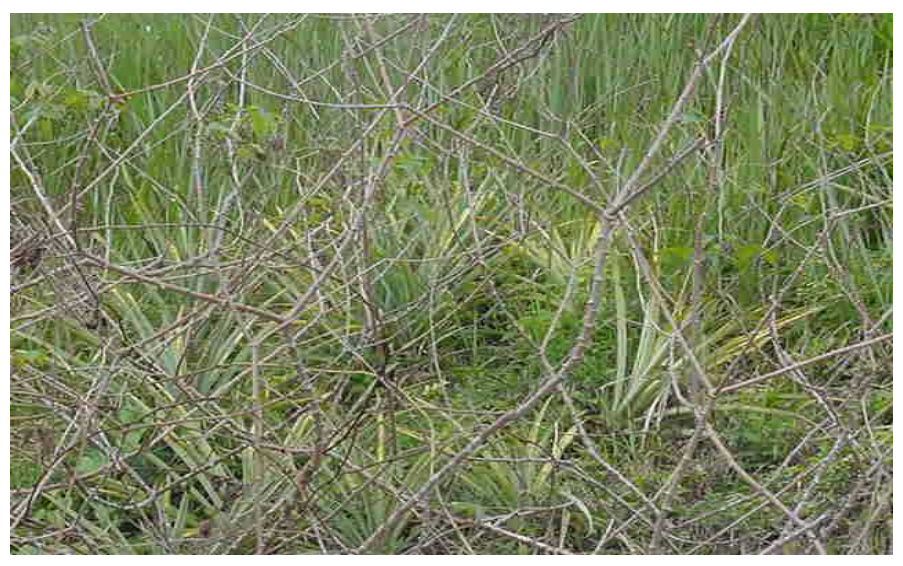

Figura 2 - Roça tradicional do Vale do Ribeira como um sistema caótico 
Esses modelos de agricultura são praticados em diferentes regiões do mundo e do Brasil, como os cultivos de arroz no Sudeste da Ásia, cultivo de batata no Chinampas do México, nos cultivos itinerantes da África, nos cultivos dos caboclos amazônicos e dos Caiçaras da Costa Sudeste do Brasil (Altieri, 2002; Martins, 2001; Hanazaki et al., 1996).

\subsection{Populações tradicionais no Brasil}

No Brasil encontramos grande variedade de modos de vida e culturas diferenciadas que podem ser considerados tradicionais, pois são fruto da intensa miscigenação entre o branco colonizador, populações indígenas e escravos negros como os caiçaras no litoral brasileiro, açorianos no litoral catarinense e rio-grandese, babaçueiros na região Meio-Norte (Goiás, Tocantins, Maranhão e Piauí), caboclos/ribeirinhos amazônicos na Floresta Amazônica, caipiras/sitiantes no Sudeste e Centro-Oeste, campeiros (Pastoreio) nos pampas e coxilhas do Rio Grande do Sul, jangadeiros na faixa costeira do Ceará e no sul da Bahia, pantaneiros no Mato Grosso e Mato Grosso do Sul, pescadores artesanais no litoral, rios e lagos, praieiros na faixa litorânea amazônica entre Piauí e Amapá, os quilombolas que são descendentes de escravos negros, sertanejos/vaqueiros no agreste e regiões semi-áridas do Nordeste e os vargeiros (ribeirinhos não-amazônicos) nas margens do Rio São Francisco (Diegues \& Arruda, 2001).

Além disso, encontramos grande diversidade de tribos e povos indígenas, com mais de uma centena de línguas diferentes. As populações indígenas mesmo fornecendo elementos culturais para as populações tradicionais, vivem em reservas, com uma legislação própria diferente da que rege as áreas naturais conservadas. No entanto, encontramos alguns grupos vivendo na periferia ou dentro das unidades de conservação. Com o isolamento relativo, essas populações desenvolveram modos de vida particulares que envolvem grande dependência dos ciclos naturais, conhecimento dos ciclos biológicos, recursos naturais, simbologias e mitos (Neiman, 1989).

Esses povos que habitam as terras baixas da América do Sul, a despeito das centenas de variantes culturais, compartilham certos padrões adaptativos como a agricultura itinerante, usam a técnica de coivara, utilizam espécies consorciadas, roças familiares. Desta forma, os agricultores tornaram-se mantenedores de um grande 
repositório de diversidade genética, e de conhecimento sobre o manejo desta diversidade, permitindo a continuidade dos processos evolutivos inerentes à relação homem-planta cultivada (Peroni \& Martins, 2000).

Após o abandono as roças permanecem como depósito alimentar seja em forma de tubérculos ou frutíferas, como reserva de caça, pois os animais são atraídos pelos cultivares.

Os agricultores tradicionais do Vale do Ribeira são denominados de caiçaras que são comunidades formadas pela mescla etno-cultural de indígenas, portugueses e escravos africanos (Figura 3). Esse grupo possui sua forma de vida baseada nas atividades de agricultura itinerante, pesca, extrativismo vegetal e artesanato. Essa cultura desenvolveu-se nas áreas costeiras dos Estados de São Paulo, Rio de Janeiro, Paraná e norte de Santa Catarina. Essas comunidades passaram a chamar a atenção de pesquisadores e de órgãos governamentais mais recentemente em virtude das ameaças à sua sobrevivência material e cultural e também por causa da contribuição histórica que essas populações têm dado à conservação da biodiversidade, pelo conhecimento que possuem da fauna e da flora e pelo sistema de manejo dos recursos naturais. Apesar disto, o risco de perda desta diversidade é muito grande devido às múltiplas influências iniciada nos anos 50 e 60 que têm incentivado os agricultores a abandonarem suas atividades agrícolas (Peroni \& Hanazaki, 2002).

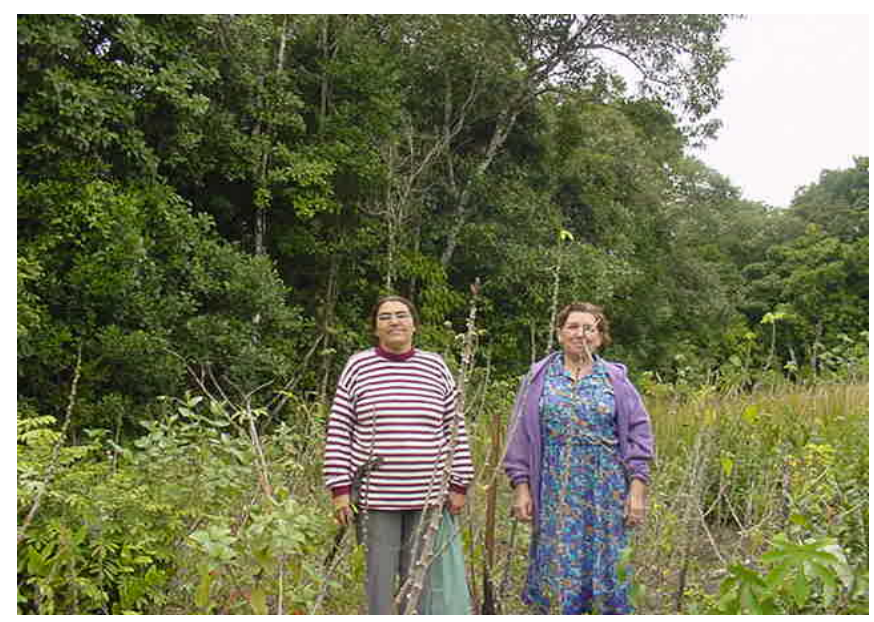

Figura 3 - Agricultoras tradicionais do Vale do Ribeira

Outro grupo importante no Vale do Ribeira são os quilombolas descendentes de escravos negros que sobrevivem em enclaves comunitários. Apesar de existirem 
desde a escravatura, no final do século XIX, sua visibilidade social é recente, fruto da luta pela terra da qual muitas vezes não tem escritura, mas tiveram seus direitos garantidos com a Constituição de 1988. Vivem da agricultura familiar, extrativismos, pesca e artesanato (Diegues \& Arruda, 2001).

A população indígena também se faz presente no Vale do Ribeira, vivendo dentro das unidades de conservação como a llha do Cardoso em Cananéia, Rio Branco e Pariquera-Açu. Os indígenas que habitam esta região são os Guaranis que podem ser divididos em três grupos: Nhandeva, Mbyas e Kaiovas, devido às ligeiras diferenças entre as numerosas aldeias. As terras indígenas são propriedade da União, de posse coletiva das etnias que as ocupam, as quais detêm legalmente o direito de usufruto exclusivo (Ladeira \& Felipim, 2000).

\subsection{Implicações do conhecimento tradicional}

Os recursos genéticos no Brasil podem ser conservados nas comunidades a que pertencem dentro do ambiente a que estão adaptadas (in situ) ou fora do seu local de origem (ex situ). Em termos de conservação, os materiais mantidos in situ possuem como vantagem sobre a conservação ex situ, a atuação das forças evolucionárias (Morales \& Valois, 2000). Porém, a conservação ex situ responde em parte as necessidades de manter uma ampla base genética para fins de melhoramento, mas limita a percepção da planta em sua dimensão biológica (Emperaire, 2002).

Grande parte da diversidade brasileira encontra-se em lugares onde as pessoas têm morado há muitas gerações, utilizando os recursos do meio ambiente de uma maneira sustentável, como é o caso das populações indígenas, caiçaras e quilombolas do litoral de São Paulo e Paraná. Essas populações recebem pouca influência no que se refere a tecnologia moderna. Na maior parte do mundo, essas comunidades estão cada vez mais entrando em contato como o mundo moderno, o que resulta em uma mudança nos seus valores (em especial os mais jovens) que estão abandonando a tradição local. As populações tradicionais têm vivido em quase todo ecossistema terrestre do mundo, há milhares de anos, como caçadores, extratores, pescadores e agricultores. Encontramos nas mais remotas florestas tropicais populações humanas esparsas vivendo em harmonia com a biodiversidade. Segundo Gómez-Pompa \& Kaus 
(1992), a grande diversidade biológica dos trópicos coexiste com as sociedades humanas há milhares de anos e os homens não danificam substancialmente a diversidade biológica ao seu redor. Portanto, a composição atual das plantas e animais em muitas comunidades biológicas é o reflexo dessas atividades, ao longo da história.

O sistema agrícola praticado pelos agricultores tradicionais é conhecido como agricultura itinerante ou agricultura de derrubada e queima, que altera a composição das espécies ao criar um mosaico de retalhos de florestas de diferentes idades. Nesse sistema, as árvores são cortadas, queimadas e o cultivo é feito sobre as cinzas ricas em nutrientes. Após uma ou várias colheitas, os nutrientes são lavados pelas chuvas e o agricultor abandona o campo e abre novas faixas na floresta para o plantio. Este sistema apresenta bons resultados quanto à preservação se a densidade da população humana for baixa e se houver uma área vasta de floresta (Martins, 2001).

Segundo Diegues \& Arruda (2001) as sociedades tradicionais possuem as seguintes características:

- Grande dependência da relação simbiótica com a natureza;

- Conhecimento aprofundado da natureza e de seus ciclos, que reflete na elaboração de estratégias de uso e de manejo dos recursos naturais;

- O conhecimento é transferido por oralidade de geração em geração;

- Ocupação de áreas por várias gerações;

- Grande importância nas atividades de subsistência, ainda que a produção de mercadoria possa estar mais ou menos desenvolvida;

- Reduzida acumulação de capitais;

- Grande importância dada à unidade familiar para o exercício das atividades econômicas, sociais e culturais;

- Importância das simbologias, mitos e rituais associados à caça, pesca e atividades extrativas;

- Tecnologia simples e de impacto limitado sobre o meio ambiente.

Se as pessoas entendessem as bases culturais e ecológicas dos sistemas onde trabalham, muitos danos poderiam ser evitados (Klee, 1980). Com grande empenho, mas sem muito êxito, o homem busca conseguir sistemas de produção autosustentáveis, ou seja, capaz de manter sua produtividade ao longo do tempo sem exaurir ou destruir as estruturas de produção. Em ambientes tropicais as dificuldades 
são ainda maiores, pois as complexidades estruturais e ambientais dificultam a utilização de modelos utilizados para ambientes temperados (Oliveira et al, 1994). Pode-se tomar como base o conhecimento que os caiçaras têm sobre ervas medicinais. Este etnoconhecimento abrange desde plantas usadas na medicina popular até algumas espécies de peixes e isto demonstra uma forte interação homem/ambiente (Trip, 2002).

Muitos antropólogos têm estudado as sociedades agrícolas tradicionais em diversas regiões do mundo por mais de um século, o que se deve ao papel fundamental exercido pelos agricultores tradicionais na conservação e geração da diversidade das espécies cultivadas (Altieri, 2002; Martins, 1994).

Desse estudo, várias questões importantes têm surgido sobre a relação social e a produção agrícola como uma atividade desenvolvida predominantemente por mulheres, além de não existir a propriedade fixa da terra, considerada como um bem comunal, embora os produtos das roças pertençam às famílias que produziram, além de influenciar a taxa atual de biodiversidade através do manejo da floresta ao longo dos séculos (Frankel, 1970; Chang, 1977; Rhoades, 1984; Clawson, 1985; Oliveira et al, 1994, Altieri, 2002). Há também aspectos dos sistemas tradicionais de conhecimentos importantes como:

- O conhecimento do agricultor tradicional sobre o ambiente físico;

- Classificação popular das espécies cultivadas (taxonomia "folk");

- Conhecimento sobre a produção agrícola.

Foi observado um equilíbrio relativo entre cultivo, hábitos humanos e práticas culturais, entre outros fatores (Altieri, 2002). Esse equilíbrio é complexo e difícil de ser modificado sem evitar perdas de recursos genéticos. Por esta razão, Altieri \& Merrick (1987) apóiam a conservação in situ da diversidade nativa e do conhecimento dos agricultores, visando a preservação dos agroecossistemas em equilíbrio. O papel das populações humanas tradicionais vai além do banco de reserva gênica, envolvendo também a geração e amplificação da variabilidade em processo contínuo (Martins, 2001).

Com o desenvolvimento de pesquisas nesta área, muitos conhecimentos agrícolas considerados como primitivos passaram a ser reconhecidos como sofisticados e apropriados para as práticas agrícolas (Altieri, 2002). 
Knight (1980) cita alguns princípios e processos que eram considerados primitivos e hoje são reconhecidos como sofisticados para os modelos de produção mais ecológicos:

- Manutenção da diversidade - proteção constante do solo e a produção de uma dieta nutricionalmente adequada. Redução da necessidade de armazenamento de alimentos e manutenção das interações bióticas que beneficiam o agricultor;

- Utilização ótima dos recursos e do espaço - plantas com diferentes hábitos de crescimento, folhas, estruturas radiculares, taxa fotossintética e extração de minerais que permitem uma melhor utilização dos fatores ambientais tais como: nutrientes, água e radiação solar;

- Reciclagem de nutrientes - manutenção da fertilidade dos solos, fechando desta forma, o ciclo de nutrientes, energia e água. Nos policultivos adota-se a rotação de culturas e o enriquecimento dos solos com as sobras da produção;

- Conservação e manejo da água - o plantio e a colheita aproveitam o período das chuvas;

- Controle da sucessão e previsão de proteção aos cultivos - desenvolvimento de estratégias para evitar a invasão de organismos indesejáveis.

São também considerados modelos de produção mais ecológicos:

- Utilização de baixo nível de tecnologia dependendo apenas dos recursos locais;

- Manutenção e geração da diversidade das espécies utilizadas para o plantio.

Esses princípios e processos evoluíram em tempos e áreas geográficas distintas, mas possuem as mesmas características estruturais e funcionais nos diferentes sistemas agrícolas tradicionais existentes no mundo (Norman, 1979). Dessa forma, o resgate e a preservação do conhecimento tradicional (etnoconhecimento) deve ocorrer de forma rápida, porque este está sendo perdido de forma irreversível, dificultando o avanço da ecologia agrícola, pois é comum os membros mais velhos das comunidades possuírem conhecimento melhor e mais detalhado que os jovens (Altieri, 2002). 


\subsection{Etnovariedades ou Landrace}

O termo Landrace ou Etnovariedade foi discutido pela primeira vez no "International Land-und Forstwirtschaftlicher Congress" realizado em Viena em 1890, porém este termo só foi amplamente discutido no "Congresso Internacional Agrícola" realizado em Roma em 1927 (Zeven, 1998). Mayr (1934 e 1937, citado por Silva, 2000) classificou as landraces em autoctones, autoctógeno, alóctone e landrace melhorada. Esses termos significam:

- Autóctone - genótipos cultivados por mais de um século em uma determinada região;

- Autoctógeno - derivado de um novo genótipo (mutante espontâneo ou cruzamento natural), originário de um landrace autóctone;

- Alóctone - landrace autóctone introduzida em outra região que se adaptou muito bem às novas condições ambientais;

- Aloctógeno - cultivada por um longo período numa região não nativa e o genótipo original ainda é reconhecido;

- Landrace melhorada - derivada de uma contaminação com uma cultivar.

As etnovariedades são raças locais, cultivadas normalmente por pequenos agricultores, na qual o melhoramento não foi efetuado, apresentando diversidade genética em relação às outras populações pela impossibilidade de fluxo gênico quando cultivado em locais diferentes, constituindo-se num reservatório de genes, o qual pode ser utilizado para formar novas variedades melhoradas ou até mesmo transmitir características desejáveis às variedades comerciais (Cereda, 2002a).

Pesquisadores como Nicolai Ivanovich Vavilov e Jack Rodney Harlan foram os pioneiros em alardear a redução global da diversidade biológica devido a intervenção humana, iniciando, desta forma, as coletas e armazenagem de um grande número de genótipos vegetais (etnovariedades) formando os primeiros bancos de genes na URSS e EUA (Harlan, 1997; Morales et al., 1997; Sambatti, 1998; Brush, 2000). Segundo Brush (1995), é difícil quantificar a extensão das perdas dos recursos genéticos na atualidade. Pois, com o advento da agricultura moderna as etnovariedades estão sendo rapidamente substituídas por cultivares melhorados em várias partes do mundo ao mesmo tempo. Outro fator importante segundo Cleveland et al. (1994) é a redução na dimensão das áreas de plantio ou pela limitação das oportunidades que os 
agricultores têm de manejar, selecionar ou mesmo trocar as etnovariedades devido à criação das unidades de conservação como ocorre no Vale do Ribeira.

\subsection{Taxonomia folk}

A etnobiologia estuda o modo como determinadas sociedades humanas, como as comunidades tradicionais, classificam, identificam e nomeiam o seu mundo natural. Essa taxonomia elaborada por tais comunidades, difunde-se oralmente (Mourão \& Nordi, 2002). Segundo os autores as classificações etnobiológicas são permeadas por um debate teórico entre duas correntes: uma denominada de utilitarista e a outra intelectualista ou cognitivista.

Os utilitaristas afirmam que os povos classificam suas espécies animais e vegetais, porque elas Ihes são úteis (Hunn, 1982, citado por Mourão \& Nordi, 2002). Por outro lado, os cognitivistas afirmam que as classificações são puramente intelectuais, geradas por uma compulsão de colocar ordem em um mundo caótico ou por simples curiosidade (Lévi-Strauss, 1970; Berlin, 1992, citados por Mourão \& Nordi, 2002).

Para a agricultura tradicional a unidade reconhecida pelo agricultor durante 0 manejo da agrobiodiversidade é a "variedade". Segundo Emperaire (2002), a variedade é o alvo das práticas agrícolas e das opções de seleção do material biológico. Portanto, uma variedade é constituída por um conjunto que apresenta características suficientemente semelhantes e diferentes dos outros conjuntos para ser reconhecido como um grupo e identificado por um nome exclusivo. Desta forma, o nome atribuído a uma variedade dá sentido ao objeto e permite sua inserção no universo das referências culturais. Porém, essa noção não é uma referência universal, mas local. Contudo, a noção de "variedade" pode encobrir diversos níveis de diversidade biológica dentro de uma mesma comunidade ou região. 


\subsection{Origem e evolução do gênero Dioscorea spp.}

O inhame pertence à família Dioscoreaceae e ao gênero Dioscorea, que possui mais de 600 espécies, 14 das quais têm seus tubérculos utilizados como alimento. É um gênero muito amplo, sendo encontrado nas regiões chuvosas dos trópicos, subtropicais e temperadas (Seagri, 2001, Montaldo, 1991). Segundo Coursey (1967), este gênero teve ampla dispersão mundial no final do período Cretáceo, ocorrendo logo após uma evolução com cursos diferentes no Velho e Novo Mundo originando espécies distintas. A separação das espécies asiáticas e africanas ocorreu, segundo o autor, mais tarde no Mioceno.

Para Vavilov (1951), citado por Montaldo (1991), as espécies Dioscorea alata e D. esculenta originaram-se em Burma e Assam na Índia (Ásia). Já Chevalier (1946), também citado por Montaldo (1991), assinala a origem africana da espécie $D$. cayenensis, pois neste continente podemos encontrá-la em seu estado selvagem. Nesses locais essa cultura é cultivada pelo homem desde a antiguidade e sua importância na alimentação do povo africano em especial sempre foi grande. A dispersão de todas as espécies para a civilização ocidental se deu com a intensificação do tráfico de escravos (Abramo, 1990).

Silva (1971) informa que a Comissão Rondon no início do século XX encontrou tribos isoladas no extremo noroeste do Estado do Mato Grosso no Brasil cultivando a espécie D. trifida, onde a denominavam de "Cará mimoso", "Cará roxo", "Cará bola" e "Cará rosado"; todos apresentavam tubérculos muito bonitos e volumosos (Abramo, 1990).

Abramo (1990) também cita que muitas variedades de inhame foram introduzidas por intermédio dos portugueses e espanhóis no século 16, durante a colonização. Porém, os portugueses e espanhóis relatam que encontraram os índios cultivando essa planta quando chegaram à América, por isso o nome "cará", que é originário da língua tupi-guarani.

Nos dias atuais é amplamente cultivada nas regiões tropicais, servindo de alimento nas Américas Central e Sul, na Ásia e nas ilhas do Pacífico. Na África, a população denomina as Dioscoreáceas como "Yam" (fome) para denominar as várias espécies de raízes comestíveis e que estão nos primeiros lugares do consumo popular (Abramo, 1990). 
As principais espécies cultivadas pela ordem de plantio são $D$. alata, com os tipos Cará S. Tomé, Cará Mandioca, Cará Flórida, seguida de D. cayenensis, com vários tipos (Cará-da-Costa, Cará Tabica, Cará Negro), D. bulbifera, D. trifida e $D$. esculenta. Chu \& Figueiredo-Ribeiro (1991) citam outras espécies nativas não domesticadas como a $D$. adenocarpa, $D$. amazonum, $D$. brasiliensis, $D$. campestris, $D$. cinnamomifolia, D. delicata, $D$. dodecaneura, D. glandulosa, D. hastata, D. laxiflora, $D$. multicolor, $D$. olfersiana, $D$. piperifolia e $D$. tuberosa. Em uma única expedição de coleta na Serra do Espinhaço, em Minas Gerais no Brasil, foram coletados 81 acessos de inhame selvagem e cultivado (Pedralli, 1990; 1994), sendo que novas coletas do material selvagem são recomendadas pelo autor.

\subsection{Botânica e cultivo do gênero Dioscorea spp.}

É uma planta herbácea, trepadeira (em geral) quando encontra apoio, com tubérculos subterrâneos (aéreos em algumas espécies nas axilas das folhas), com o caule aéreo volúvel podendo ou não apresentar espinhos; as folhas apresentam heterofilia (são estreitas na forma de ponta de faca), com flores brancas, amarelas ou verde-claras. A propagação é realizada por tubérculos e sementes (Seagri, 2001; Montaldo, 1991).

As espécies de inhame apresentam sistema reprodutivo por alogamia e propagação vegetativa. As plantas de inhame são em sua grande maioria espécies dióicas, embora plantas monóicas tenham sido observadas em algumas espécies cultivadas (Zoundjihekpon et al., 1997). As plantas possuem inflorescência na forma de espigas axilares, geralmente solitárias, raramente ocorrendo aos pares, com flores trímeras verdes de 4 a $6 \mathrm{~mm}$ de diâmetro. As flores masculinas possuem perigônio com 6 peças em dois verticílos, apresentando seis estames com anteras férteis, distribuídas em um só verticílo. O fruto do cará é uma cápsula com três locos, cada um com duas sementes diminutas e aladas (Silva, 1971).

Contudo, a floração é muito escassa em quase todas as espécies alimentícias cultivadas. Rizomas podem ser solitários ou em grupos. $O$ peso dos tubérculos varia de 50 a $1.000 \mathrm{~g}$ e em algumas espécies de $D$. alata podem alcançar até $2 \mathrm{~kg}$. 
O gênero é muito amplo, porém pode ser dividido em seções como: Enantiophyllum (D. alata e D. cayenensis), Combilium (D. esculenta), Osophyton (D. bulbífera) e Macrogynodium (D. trifida).

As principais características de cada espécie podem ser agrupadas da seguinte forma (Montaldo, 1991):

- D. alata - apresenta tubérculos solitários ou agrupados de 2-4, redondos, cilíndricos, oblongos ou de forma irregular. Alguns tubérculos podem chegar a pesar 2$3 \mathrm{~kg}$. Presença de tubérculos aéreos. Talos fortemente alados, sem espinho, verdes ou púrpura. A torção dos talos é no sentido anti-horário. Folhas encouraçadas, simples e opostas. Na atualidade constitui na principal espécie cultivada dos trópicos;

- D. cayenensis - tubérculo solitário variando de 1-10 kg, geralmente grosso e ramificado, com polpa amarela. Caule cilíndrico, espinhoso, que se enrola pela direita. Folhas simples, eretas, opostas e alternadas encouraçadas. Espécie muito cultivada na África Ocidental e alguns países na América Tropical. Segue em importância mundial à D. alata.

- D. bulbifera - um tubérculo subterrâneo por planta, branco e globoso, às vezes amargo e comestível. Tubérculos aéreos podem chegar a 100 - 200 g; estes são utilizados como alimento. Caules cilíndricos sem espinhos com torção para a esquerda. Folhas simples, eretas, grandes alternadas ou opostas. Cultivado no sudeste da Ásia, África, Ilhas do Pacífico e América;

- D. trifida - tubérculos pequenos de $15 \mathrm{~cm}$ de largura, redondos ou cônicos. Polpa branca, amarela ou púrpura. Excelente qualidade culinária. Caules quadrangulares, alados e sem espinhos. Torção pela esquerda. Folhas palmadas, profundamente lobuladas, alternadas, raramente opostas. Muito cultivada e originaria da América Tropical.

O inhame é uma planta do grupo das olerícolas, muito rústica, resistente a seca, pouco exigente ao tipo de solo e adubação, dispensa aplicação de fungicidas e inseticidas e não apresenta necessidade de renovação periódica de sementes, além de produzir tubérculos comestíveis (Murayama, 1999; Zarate et al., 1996). O que afeta seriamente a cultura é a requeima da folhagem, distúrbio de natureza desconhecida, que se caracteriza pela formação de manchas negras necróticas nas hastes e folhas das plantas (Murayama, 1999). 
O plantio é feito em uma época anterior a estação chuvosa, utilizando os inhames pequenos ou sementes; outra forma é a propagação por estacas herbáceas (Mantilla \& Vargas, 1984). Para a espécie D. bulbifera podem ser utilizados os bulbinhos aéreos.

A produção de sementes verdadeiras é possível para as espécies $D$. trifida e $D$. bulbifera; as demais espécies alimentícias tropicais não produzem regularmente sementes. Este método de propagação é muito importante para fins de melhoramento genético, porém não para produção comercial de inhame (Montaldo, 1991).

Montaldo (1972) cita que para a cultura do inhame a utilização em larga escala de sementes provenientes da reprodução por alogamia é um fato raro, pois as espécies alimentícias em sua grande maioria apresentam raro florescimento e o tamanho e a facilidade de dispersão das sementes dificultam sua utilização nas roças. Outro fator que dificulta o cruzamento natural, segundo Zoundjihekpon et al. (1997), é a diferença entre a época de florescimento das plantas femininas e masculinas, ou seja, as plantas masculinas têm o florescimento vinte e cinco dias mais cedo que as femininas para a espécie $D$. alata. Porém, existe uma pequena sobreposição de dez dias entre o florescimento de ambas as flores.

Segnou et al. (1992) sugere práticas culturais como a irrigação e adubação visando estender o período de florescimento entre as plantas permitindo cruzamentos naturais e controlados para o melhoramento desta espécie.

$\mathrm{Na}$ reprodução por estacas devem-se usar plantas vigorosas com mais de três meses de idade. Cada estaca deve ter um nó e enraizar em água ou outra substância antes de plantar definitivamente no campo. Mantilla \& Vargas (1984) utilizaram esse método de estacas herbáceas com um nó, obtendo num prazo de 20 dias uma boa brotação e enraizamento. Os autores indicam que é possível retirar entre 50 e 120 estacas de uma folha por planta adulta (8 meses). A produção de plantas provenientes de estaca é baixa, porém este procedimento é utilizado quando se requer efetuar a propagação rápida de um material de alto valor genético.

Os bulbinhos aéreos podem ser utilizados na propagação das espécies $D$. bulbifera, $D$. alata e $D$. cayenensis. Na espécie $D$. bulbifera faz se necessário provocar incisões nos tecidos dos talos para promover a formação dos bulbinhos. Este método tem a vantagem de economizar os tubérculos de valor comercial. 
As espécies em sua grande maioria apresentam um período de latência dos tubérculos-sementes que geralmente varia de 3 a 4 meses depois da colheita. Segundo Zerate et al. (1996), o ciclo completo da cultura é de 6 a 12 meses e o período adequado para o produtor efetuar a colheita é de três a quatro semanas após o secamento dos ramos, tempo necessário para a maturação dos tubérculos.

\subsection{Nomes populares para Dioscoreaceae no Brasil}

Segundo Pedralli (2002), a origem dos nomes vulgares de algumas espécies muitas vezes é obscura ou mesmo impossível de ser identificada. Desta forma, os nomes populares variam de local para local, de região para região e de um país para outro.

No Brasil, durante muitas décadas, os nomes vulgares do inhame, cará e taro vêm causando grande confusão, a qual estendeu-se tanto para as informações técnicas como estatísticas (Santos, 2002). Muitas são as dificuldades ocasionadas pela divulgação equivocada dos nomes populares dos gêneros Dioscorea e Colocasia, tais como os resultados da pesquisa científica ou mesmo no processo de comercialização e exportação desses produtos. Pode-se observar que os nomes populares de inhame (igname, name ou yam) são dados em todos os idiomas ao gênero Dioscorea, enquanto apenas em algumas regiões do Brasil, compreendendo São Paulo e suas regiões de influência técnica, Rio de Janeiro, Minas Gerais e Espírito Santo, denominam este mesmo gênero de cará sob influência dos índios Guaranis que viviam nesta região e cultivavam esta espécie.

Essa confusão de nomes pode ser observada na reportagem do Suplemento Agrícola de Quarta-feira, 22 de Setembro de 2004 - N² 2.550 do jornal O Estado de São Paulo (Figura 4). Na capa observa-se uma reportagem intitulada de "Inhame bom de preço: Safra da raiz está se encerrando e o produto é vendido com boas cotações, tanto para o mercado interno quanto para a exportação". Na página quatro encontra-se a divulgação equivocada do nome popular de inhame para os gêneros Dioscorea e Colocasia. A reportagem "Inhame tem bom preço aqui e lá fora" (Melo, 2004a) trata do gênero Colocasia no Estado de São Paulo, cuja espécie cultivada é também conhecida como "inhame" neste Estado; já a reportagem "Assentados colhem primeira safra no Rio Grande do Norte" trata do gênero Dioscorea (Melo, 2004b). Essas confusões 
podem trazer problemas durante o processo de comercialização e exportação.

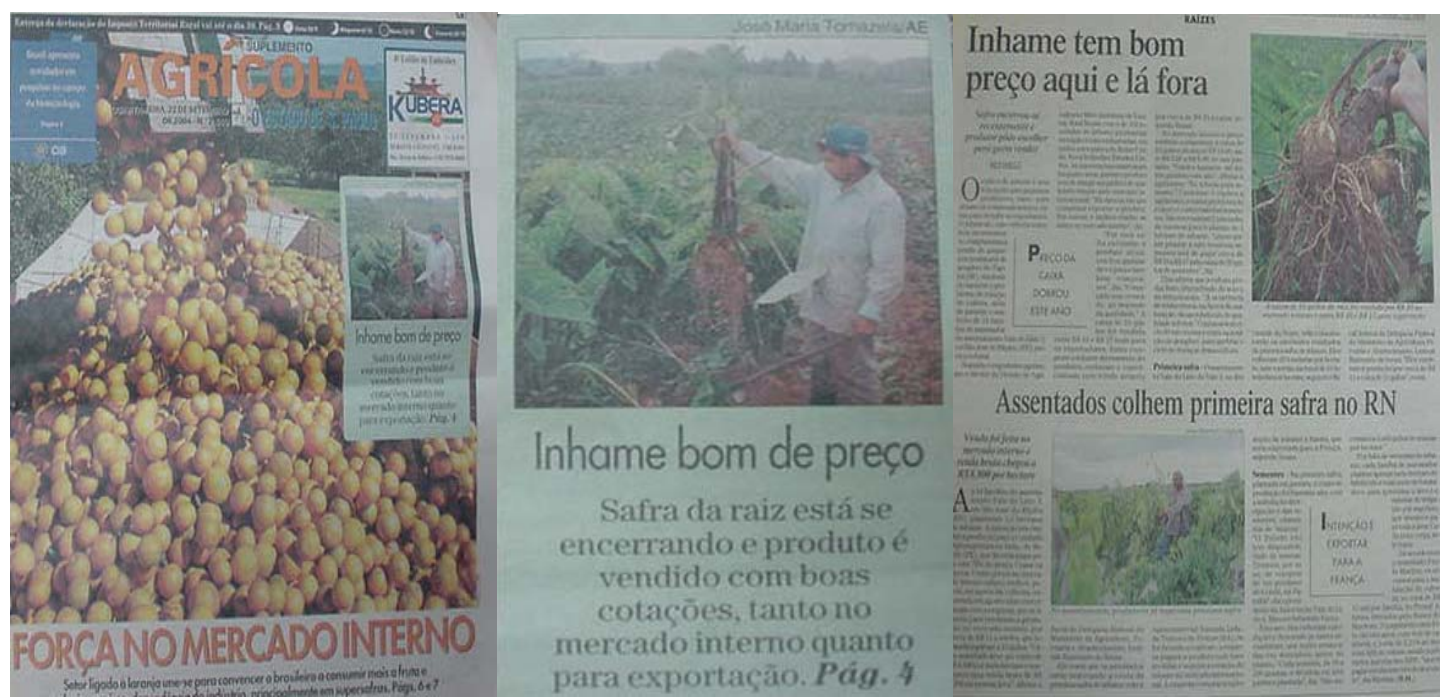

Figura 4 - Matéria equivocada do jornal "O Estado de São Paulo”

Nos anos de 1997 e 1999 o International Plant Genetic Resources Institute (IPGRI) definiu os descritores para as espécies de Dioscorea e o nome adotado por este grupo foi de "yam" ou inhame. Desta forma, Pedralli (2002) em seu artigo apresenta a proposta de padronização da nomenclatura do "inhame" e do "cará", aprovada no "I Simpósio Nacional sobre as culturas do Inhame e do Cará", realizado em Venda Nova dos Imigrantes - ES em abril de 2001. Assim sendo, ficou estabelecido que os órgãos governamentais, universidades, empresas de pesquisa e extensão rural, Sociedade de Olericultura do Brasil e demais entidades divulguem e oficializem a nova denominação definitiva de inhame para as Dioscoreáceas (Cereda, 2002b).

Contudo, os nomes populares dados para as etnovariedades pelos agricultores tradicionais do Vale do Ribeira no Estado de São Paulo permanecem os mesmos, pois estes não reconhecem esta nova nomenclatura.

\subsection{Genética e melhoramento do gênero Dioscorea spp.}

O número básico de cromossomos das Dioscoreáceas é $x=9$, porém Darlington \& Wylie (1955), citados por Montaldo (1991) assinalam que D. alata apresenta 40 cromossomos. Para as espécies africanas $D$. cayenensis e $D$. rotundata, 
Miége (1954) indica 36 e 54 cromossomos, correspondentes aos tipos tetraplóides e hexaplóides.

Para $D$. bulbifera, as variedades asiáticas têm números de cromossomos múltiplos de $20(40,60,80$ e 100) e as variedades africanas têm conteúdo cromossomal de 36, 40, 54 e 60, baseados em múltiplos de 9 e 10.

Martin (1974b), citado por Montaldo (1991), supõe que durante a evolução da espécie perdeu-se um cromossomo do progenitor das variedades de 36 e 54 cromossomos. No caso de D. trifida, esta apresenta 2x $=18$ (diplóide), $4 x=36$ (tetraplóides) e 6x $=54$ (hexaplóides).

Comparando tipos silvestres, semi-silvestres com os atuais cultivares podemos observar que houve a intervenção do melhoramento sexual controlado, pois é possível notar certos avanços para algumas características de interesses do homem como a qualidade dos tubérculos.

Desta forma, para os cultivares atuais dentro das principais espécies comestíveis, em especial D. alata, D. cayenensis, D. trifida, D. esculenta e D. bulbifera, a seleção clonal tem sido feita através de muitos anos desde a sua domesticação.

Segundo Montaldo (1991), os pesquisadores do IITA, Nigéria, observaram os cruzamentos das principais espécies cultivadas e sua ampla diversidade genética como:

- Altura e vigor;

- Cor, tamanho e forma de folha, caules e rizomas;

- Variabilidade reprodutiva quanto ao período de florescimento, tipos de flores, tamanhos e as formas dos frutos e sementes;

- Resistência às enfermidades.

Desta forma, o melhoramento genético pode oferecer grandes possibilidades de trabalho como:

- Tamanho e forma de rizomas para permitir uma colheita mecanizada;

- Boas características para o processamento industrial;

- Máxima resposta aos fertilizantes;

- Bom valor nutritivo, não só no conteúdo, mas também na qualidade da proteína e amido; 
- Boas condições de armazenamento e baixa atividade metabólica durante a conservação;

- Ampla adaptação às condições climáticas adversas.

\subsection{Aspectos econômicos e utilização do gênero Dioscorea spp.}

A comercialização dos inhames é local, portanto as estatísticas são bastante dispersas e irregulares. Somente em 1975 a FAO adicionou a produção de inhame nas estatísticas mundiais (Santos \& Macedo, 2002).

Na África, em especial na Costa do Marfim, Gana, Nigéria, $80 \%$ das calorias obtidas da alimentação são provenientes dos inhames e mandioca, correspondendo deste total $52 \%$ aos inhames (Mascarenhas \& Resende, 2002).

Os principais países produtores são na África a Nigéria, Costa do Marfim e Gana com $73 \%$ da produção mundial e produtividade de 9,4 toneladas/hectare; na América o Brasil, Colômbia, Haiti e Venezuela com produtividade de 7,3 toneladas/hectare; na Ásia o Japão e Filipinas com 9,8 toneladas/hectare e na Oceania a Papua Nova Guiné com 13,8 toneladas/hectare (Santos \& Macedo, 2002).

No Brasil, o inhame desempenha importante papel sócio-econômico nas regiões Sudeste (Rio de Janeiro, Minas Gerais, Espírito Santo e São Paulo) e Nordeste, em especial nos Estados da Paraíba, Pernambuco, Alagoas, Bahia e Maranhão, onde esta cultura presta grande contribuição ao desenvolvimento rural regional. Nesses Estados essa espécie produz túberas de alto valor nutritivo e energético, constituindo um alimento básico para a população carente (Santos \& Macedo, 2002).

A produção brasileira é destinada em grande parte ao mercado interno, sendo também exportada, principalmente, para a Europa. Em 1999 foram produzidas 225 mil toneladas em uma área de 25 mil hectares com uma produtividade média de 9.725 $\mathrm{kg} / \mathrm{ha}$. Os pequenos grãos de amido são responsáveis pela alta digestibilidade desse alimento favorecendo desta forma, sua utilização na dieta humana (Santos \& Macedo, 2002; Mascarenhas \& Resende, 2002). 
No Estado de São Paulo as principais variedades cultivadas comercialmente, pertencem à espécie $D$. alata (Murayama, 1999):

- Variedade caipira: produz tubérculos de má aparência, com casca áspera e de cor escura, produzindo grande quantidade de pequenos e imprestáveis tubérculos aéreos, além de possuir qualidade culinária inferior;

- Variedade mimoso: variedade introduzida pelos portugueses, produzindo tubérculos de diferentes formas, porém de qualidade culinária superior; é uma variedade muito sensível a requeima;

- Variedade flórida: apresenta tubérculos de ótima qualidade para o mercado consumidor (uniforme e casca lisa), é resistente a requeima, e precoce.

O inhame pode ser utilizado de diversas formas como:

- Alimentação humana - até agora a principal forma de consumo na África onde tem se dado preferência ao inhame em lugar da mandioca na preparação do fufu, alimento tradicional das populações e mesmo a farinha de inhame (Costa do Marfim, Gana, Togo, Nigéria). Em países tropicais como o Brasil é utilizado na culinária como substituto da batata inglesa, da batata doce e da mandioca, pois é um alimento de fácil digestibilidade, indicado para diversos tipos de dietas. Os tubérculos apresentam características que facilitam seu armazenamento, ou seja, não se deteriora após a colheita, podendo ser conservado à sombra em estado natural por até 90 dias, devido a sua rusticidade;

- Alimentação animal - Martin \& Gallo (1973) estudaram a digestibilidade e energia metabolizante do inhame em suínos apresentando bons resultados;

- Medicina e farmacologia - muitas espécies selvagens apresentam substâncias denominadas de sapogeninas, cuja estrutura química tem a mesma constituição dos corticóides (cortisona, hormônios sexuais e contraceptivos). Muitas espécies de Dioscorea apresentam três classes de sapogeninas como a diosgenina, botogenina e a criptogenina que possuem estrutura semelhante a de muitos compostos hormônais dos animais, porém a mais utilizada para síntese desses produtos é a diosgenina. Além disso, os tubérculos são ricos em carboidratos, proteínas, vitamina $C$, riboflavina, ácido nicotínico, ácido ascórbico, ß-caroteno, provitamina A, provitamina $\mathrm{D}$, amido, cálcio, fósforo, ferro, vitamina B1, B2, alcalóides lactônicos, fitosteróis (colesterol, campesterol, estigmasterol, ß-sitosterol), glucanos, glucamananos, lipídios, taninos, 
antocianina e quitinases glicoprotéicas (Seagri, 2001). Algumas espécies podem ser utilizadas no controle de problemas estomacais (adstringente), desnutrição e convalescença (nutritiva e energizante), controle do colesterol, infecções fúngicas, bacterianas e viróticas, arteriosclerose cerebral, diabetes, síntese de contraceptivos orais, hormônios sexuais, cortisona (para tratamento de artrite reumática, alergias e doenças reumáticas), na prevenção de osteoporose, anti-helmíntica, anti-tumoral, diurética e hipoglicêmica (Seagri, 2001).

\subsection{Estimação da diversidade por meio de marcadores isoenzimáticos}

O estudo da diversidade genética em populações naturais era insatisfatório em um período anterior a aplicação da técnica de eletroforese, porque dependia da identificação e enumeração dos mutantes recessivos raros que em homozigose produziam características morfológicas visíveis e às vezes deletérias (Torggler et al., 1995; Alfenas, 1998).

O termo isoenzima define um grupo de múltiplas formas moleculares da mesma enzima que ocorre em uma espécie, resultante da presença de mais de um gene codificando cada uma das enzimas. O princípio básico da técnica reside no uso de eletroforese em gel (amido, poliacrilamida, etc) e na visualização do produto enzimático por métodos histoquímicos (Hames, 1996; Ferreira \& Grattapaglia, 1998).

Segundo Ferreira \& Grattapaglia (1998), a difusão do uso de isoenzimas ocorreu através do desenvolvimento de métodos eficientes para visualização do produto enzimático e da aplicabilidade imediata encontrada em várias áreas da biologia.

Esta técnica vem sendo utilizada desde 1950 com muita eficiência para estimar e avaliar o grau de variabilidade genética em populações naturais e cultivadas, o fluxo gênico, hibridação, relação filogenética, e empregada nos estudos da distribuição da variabilidade genética entre e dentro de roças de etnovariedades de mandioca (Peroni, 1998; Faraldo, 1994, 1999; Sambatti et al, 2001). Desta forma, a análise isoenzimática constitui numa maneira rápida, simples e de alto valor informativo de avaliar genotipicamente muitos locos em um grande número de indivíduos (Smithies, 1955, Faraldo, 1999; Silva, 2000; Faraldo et al., 2002). Mesmo havendo na atualidade técnicas suplementares que ampliam o poder de detecção dos efeitos das mutações 
ao nível de DNA, a isoenzima continua apresentando um potencial enorme para a genética de plantas (Torggler et al., 1995).

A caracterização isoenzimática tem sido empregada no estudo genético em acessos do complexo D. cayenensis-rotundata (Hamon \& Toure, 1990; Zoundjihekpon et al., 1994; Dansi et al., 2000). Os resultados obtidos por Hamon \& Toure (1990) utilizando cinco sistemas enzimáticos: malato desidrogenase $(\mathrm{MDH})$, isocitrato desidrogenase (IDH), 6-fosfogluconato desidrogenase (6PGDH), xiquimato desidrogenase (SKDH) e glucose-6-fosfato isomerase (GPI), para 453 acessos do complexo $D$. cayenensis-rotundata, mostraram boa concordância entre o polimorfismo isoenzimático e a variação morfológica.

Diferentes padrões de bandas de sete sistemas enzimáticos: aspartato aminotransferase (AAT), esterase (EST), glucose-6-fosfato desidrogenase $\left(\mathrm{G}_{6} \mathrm{PDH}\right)$, IDH, fosfoglucomutase (PGM), GPI e SKDH levaram à identificação de 227 diferentes cultivares, de um total de 467 acessos analisados do complexo D. cayenensisrotundata da República de Benin (Dansi et al., 2000). Zoundjihekpon et al. (1994) analisaram progênies obtidas a partir do cruzamento de variedades tetraplóides do complexo $D$. cayenensis-rotundata, observando diversos padrões de segregação para seis sistemas enzimáticos: EST, IDH, MDH, 6PGDH, SKDH e GPI, trazendo informações sobre a genética dos sistemas analisados.

\subsection{Estimação da diversidade por meio de descritores morfológicos}

A caracterização morfológica é expressa através dos descritores. Para a cultura do inhame (Dioscorea spp.), os descritores utilizados na caracterização morfológica são os preconizados pelo IPGRI e International Institute of Tropical Agriculture (IITA), em Ibadan, Nigéria, descritos com suas respectivas escalas de notas, em IPGRI/ITA (1997). Além dos descritores preconizados a publicação do IPGRI fornece uma chave de identificação de espécies de Dioscorea spp. A qual foi utilizada na classificação das espécies cultivadas no Vale do Ribeira.

Portanto, existe uma extensa lista de descritores, tanto morfológicos como agronômicos que podem ser empregados para a caracterização da diversidade das espécies de inhame. Onyilagha (1986) avaliou 14 acessos de $D$. rotundata utilizando 40 caracteres morfológicos, os quais foram classificados em três grupos, tanto na 
análise de agrupamento como na análise de componentes principais (PCA). A análise de PCA mostrou que os caracteres com maior poder discriminatório foram: tamanho da folha, tamanho do tubérculo, cor do tubérculo, número de espiguetas florais por nó, e comprimento da espigueta. Rhodes \& Martin (1972) utilizaram 100 caracteres para estudar a variação em 30 cultivares de $D$. alata, concluindo que apenas 28 foram úteis para a classificação dos cultivares.

O grande problema enfrentado na utilização da caracterização morfológica é a natureza quantitativa dos caracteres que são fortemente influenciadas pelo ambiente, pois depende da identificação e enumeração de características morfológicas visíveis que muitas vezes tornam-se subjetivas para o avaliador.

Desta forma, a utilização de grande número de descritores tem sido um procedimento generalizado na caracterização da variabilidade dos acessos, em razão da ausência de informação precisa sobre a real contribuição de cada descritor. Todo caráter deve contribuir de alguma maneira para descrever a variabilidade, porém, à medida que cresce o número de descritores, aumenta a possibilidade de serem redundantes ou correlacionados (Alves, 2002), não aumentando desta forma, a precisão da avaliação.

Portanto, é desejável que sejam eliminados das avaliações os descritores redundantes, com baixa variabilidade e expressão (Cury, 1993).

\subsection{Análise de variância molecular (AMOVA)}

A introdução da estatística $F$ por Excoffier et al. (1992) abriu caminhos para a utilização de uma nova ferramenta na análise de marcadores dominantes. Esta análise de variância molecular (AMOVA) produz estimativas dos componentes de variância das análogas estatísticas $\mathrm{F}$ de Wright $(\Phi)$, que correlacionam a diversidade dos haplótipos em diferentes níveis hierárquicos (Zucchi, 2002). A estatística $\Phi$ é testada através do uso de permutações. Excoffier et al. (1992) aplicaram esta análise a dados de haplótipos de DNA mitocondrial humano em dez populações humanas representando cinco grupos regionais com duas populações cada e verificaram que as subdivisões na população são mais bem explicadas por este tipo de análise.

Huff et al. (1993) utilizaram pela primeira vez essa ferramenta para populações naturais em plantas, estudando a variação genética entre e dentro de populações 
naturais de Buchloe dactyloides provenientes de quatro populações mexicanas e duas norte-americanas (Texas). Após 1993, muitos autores passaram a utilizar a AMOVA para descrever a estrutura genética de populações, como Buso et al. (1998), Maki \& Horie (1999), Gillies et al. (1999), Fischer et al. (2000), Jiménez et al. (2002), Zucchi (2002), Cavallari (2004), entre muitos outros.

Desta forma, a AMOVA apresenta, entre outros, o seguinte esquema de análise (Tabela 1), segundo Zucchi (2002).

Tabela 1. Análise de variância molecular (AMOVA)

\begin{tabular}{ccccc}
\hline Variação & $\mathrm{GL}$ & $\mathrm{SQ}$ & $\mathrm{QM}$ & $\mathrm{E}(\mathrm{QM})$ \\
\hline Entre populações & $\mathrm{P}-1$ & $\mathrm{SQ}_{\mathrm{A}}$ & $\mathrm{QM}_{\mathrm{A}}$ & $\sigma_{\mathrm{B}}{ }^{2}+2 \sigma_{\mathrm{A}}{ }^{2}$ \\
Dentro de populações & $\mathrm{N}-\mathrm{P}$ & $\mathrm{SQ}_{\mathrm{B}}$ & $\mathrm{QM}_{\mathrm{B}}$ & $\sigma_{\mathrm{B}}{ }^{2}$ \\
Total & $\mathrm{N}-1$ & & & \\
\hline
\end{tabular}

Onde: $\mathrm{P}$ - número total de populações; $\mathrm{N}$ - número total de dados genotípicos; $\sigma_{A}{ }^{2}$ - variância genética dentro de regiões; $\sigma_{B}{ }^{2}$ - variância genética dentro de populações.

Segundo Cockerham (1969), citado por Zucchi (2002), os componentes de variância de cada nível hierárquico são extraídos das esperanças dos quadrados médios como:

$$
\Phi_{\mathrm{ST}}=\sigma_{\mathrm{A}}^{2} / \sigma^{2}
$$

Onde: $\Phi_{\mathrm{ST}}=$ a proporção da variabilidade molecular de haplótipos entre populações.

\subsection{Correspondência entre distâncias genéticas e geográficas}

A relação entre a diversidade genética (isoenzima e morfologia) e a diversidade geográfica está ligada à história vital de cada espécie.

Dias (1994) cita que as espécies sofrem pressão de forças evolutivas como a seleção, deriva genética, fluxo gênico, segregação, entre outros fatores que podem atuar conjunta ou isoladamente em diferentes intensidades, determinando, desta forma, a existência ou não de um paralelismo entre diversidade genética e geográfica. 
Cury (1993) cita a ausência da relação entre diversidade geográfica e ecológica com divergência genética na cultura da mandioca ( $M$. esculenta Crantz). Já Zucchi (2002) em seu trabalho analisou os padrões de variação espacial para a espécie Eugenia dysenterica pelo coeficiente de correlação de Pearson ( $r$ ) utilizando as matrizes de distâncias genéticas calculadas pelo índice de similaridade de Jaccard e as distâncias geográficas entre as populações. O nível de significância desta correlação matricial foi testada pelo método estatístico de Mantel (Z). Obteve como resultado relação positiva entre a diversidade ecológica e geográfica.

Segundo Manly (1997), o valor Z de Mantel é obtido por:

$$
Z=\sum_{i j} X_{i j} Y_{i j}
$$

Onde: $X_{i j}$ e $Y_{i j}$ são elementos das matrizes de distância geográfica $(X)$ e genética $(Y)$ a serem comparadas.

O nível de significância do teste de Mantel é dado por $p$, o qual é estimado pela comparação entre $r$ observado e a distribuição de $r$ obtidos pelas permutações. A relação de $Z$ possui uma relação monotônica com o $r$ de Pearson entre as matrizes, de modo que o $Z$ é utilizado para testar a significância do r (Telles et al., 2003).

A concordância entre as distâncias genéticas (isoenzima e morfologia) também podem ser obtidas pelo coeficiente de correlação de Pearson ( $r$ ) calculadas pelo índice de similaridade de Jaccard. O nível de significância da correlação matricial também pode ser testada pelo método estatístico de Mantel (Z).

A concordância entre os dados depende da espécie envolvida e da metodologia empregada. Fryer (1987) encontrou padrões de variabilidade muito similares entre dados isoenzimáticos e morfológicos em populações de Pinus rígida. Veasey (1998) também verificou que as análises de agrupamento realizadas com dados isoenzimáticos e agronômicos separam as espécies anuais de perenes de Sesbania spp. 


\section{COLETA DE GERMOPLASMA DE INHAME (Dioscorea spp.) EM ROÇAS E QUINTAIS DE AGRICULTORES TRADICIONAIS DO VALE DO RIBEIRA, SÃO PAULO, BRASIL}

\section{Resumo}

O gênero Dioscorea está distribuido pelas regiões tropicais, subtropicais e temperadas do mundo. No Brasil são conhecidos como inhames no Nordeste ou cará no Sul e Sudeste. No Vale do Ribeira, região sul do Estado de São Paulo, encontramse agricultores tradicionais cultivando espécies de Dioscorea spp. nas roças de toco. Essa agricultura é praticada há milênios em diversas partes do mundo e nos trópicos possui grande interação com os ecossistemas de floresta. Os agricultores tradicionais do Vale do Ribeira utilizam o inhame na alimentação e em alguns casos com intuito farmacêutico. Essa pesquisa objetivou coletar etnovariedades de inhame (Dioscorea spp.) nas roças e quintais dos agricultores tradicionais do Vale do Ribeira, visando formar uma coleção de germoplasma para conservação ex situ que permitisse a identificação, caracterização e avaliação da diversidade mantida e manejada por esses agricultores. Quarenta e cinco das 91 propriedades visitadas cultivavam o inhame, na seguinte distribuição: $31 \%$ em roças itinerantes e $69 \%$ em quintais. Os agricultores relataram que plantavam outras etnovariedades de inhame no passado, mas por diversas razões como, por exemplo, a legislação ambiental vigente deixaram de cultivá-las. Encontraram-se quatro espécies coletando-se os seguintes números médios de etnovariedades por roça: $D$. trifida com $1,5, D$. bulbifera com $1,7, D$. alata e D. cayenensis com 1,2. Dessa forma, verificou-se que a grande maioria dos agricultores cultivavam apenas uma etnovariedade de cada espécie. Englobando-se todas as espécies, o número médio de etnovariedades passa para 2,0, ou seja, os agricultores cultivam mais de uma espécie mesmo sem fazer essa distinção. Anotaram-se os nomes populares que são freqüentemente associados com aspectos morfológicos dos tubérculos ou com o ciclo de vida de cada etnovariedade. Verificou- 
se, portanto, que os agricultores cultivam grande diversidade de etnovariedades e espécies de Dioscorea no Vale do Ribeira. Contudo, a redução na área de cultivo poderá no futuro provocar uma perda de diversidade de plantas cultivadas pelos agricultores tradicionais. 


\section{GERMPLASM COLLECTION OF YAM (Dioscorea spp.) IN SWIDDENS AND HOME GARDENS OF TRADITIONAL AGRICULTURE OF THE RIBEIRA RIVER VALLEY, SÃO PAULO, BRAZIL}

\section{Summary}

Dioscorea is distributed in tropical, subtropical and temperate regions of the world. In Brazil they are known as yam in the Northeast or "cará" in the South and Southeast. At the Ribeira River Valley, south region of the State of São Paulo, traditional agriculturists cultivate species of Dioscorea in swiddens using the slash and burn system. This agriculture has been practiced for milleniums in diverse parts of the world and in the tropics it possesses great interaction with forest ecosystems. The traditional agriculturists of the Ribeira River Valley use yam as food and, in some cases, as medicinal purposes. This research had the objective of collecting ethnovarieties of yam (Dioscorea spp.) in swiddens and home gardens of the traditional agriculturists of the Ribeira River Valley, with the aim of establishing a germplasm collection for ex situ conservation, which would allow the identification, characterization and evaluation of the diversity kept and managed by these agriculturists. Forty-five of the 91 agriculturists visited cultivated yam in the following distribution: $31 \%$ cultivating in itinerant swiddens and $69 \%$ in home gardens. Other ethnovarieties were planted in the past, according to the agriculturists, but for diverse reasons as, for example, the effective environmental legislation, were no longer cultivated. Four species are cultivated with the following average number of ethnovarieties per swidden/home garden: $D$. trifida with 1,5, $D$. bulbifera with $1,7, D$. cayenensis and $D$. alata with 1,2 . Therefore, the great majority of the agriculturists cultivate only one variety of each species. With all four species together, the average number of ethnovarieties is 2,0 , which means that the agriculturists cultivate more than one species without making this distinction. Common names have been recorded which are frequently associated with morphological aspects of the tubers or the life cycle of each ethnovariety. It was verified, therefore, that the agriculturists cultivate a great diversity of ethnovarieties and species of Dioscorea. However, the reduction in the cultivation area may cause, in the future, a loss of plant diversity cultivated by the traditional agriculturists. 


\subsection{Introdução}

As dioscoreáceas estão distribuídas pelas regiões tropicais, subtropicais e temperadas de todo o mundo (Pedralli, 1988). O gênero Dioscorea, ao qual pertence a maioria das espécies cultivadas e silvestres da família, engloba espécies tropicais originárias da África, Ásia e América (Pedralli, 1990).

No Brasil, são conhecidos popularmente como inhames no Nordeste do país ou carás no Sul e Sudeste, onde o nome inhame é atribuído a outra planta gerando, desta forma, muita confusão. As dioscoreáceas são, em geral, plantas de ciclo anual. No final do inverno morrem seus ramos. A regeneração da parte aérea se dá a partir de um tubérculo subterrâneo, do qual brota uma erva ou liana (trepadeira) que necessita de suporte de árvores, arbustos ou ramos e caules (Montaldo, 1991). Na sua maioria são plantas heliófilas. Na América Central encontra-se uma espécie epífita, vivendo sobre outra planta sem retirar desta o seu sustento (Pedralli,1988).

Os inhames são cultivados nas orlas das florestas e savanas, especialmente nas áreas mais úmidas (Pedralli,1988). A importância econômica da maioria das espécies está ligada ao cultivo para alimentação humana devido ao alto teor de vitaminas, sais minerais e amido, bem como ao uso medicinal no combate de diversas enfermidades.

Os tubérculos, em muitas espécies, possuem taninos, alcalóides, substâncias alergênicas, mucilagem e diosgenina que é usada na síntese de esteróides, daí resultando seu grande valor farmacêutico. As espécies de Dioscorea fornecedoras de diosgenina, no entanto, não servem para alimentação humana (Pedralli,1990).

Em todo o Brasil encontra-se o cultivo de carás ou inhames (Dioscorea spp.) originários de diversas partes do mundo como a América Central, Ásia e África.

Na região sul do Estado de São Paulo, particularmente no Vale do Rio Ribeira, importante área de preservação da Floresta Atlântica, encontramos agricultores tradicionais praticando a agricultura de corte e queima, mantendo e manejando grande diversidade de plantas cultivadas (Peroni \& Hanazaki, 2002).

Peroni (1998) listou o número de variedades de tuberosas encontradas em uma roça de agricultores tradicionais na comunidade de Ariri no Vale do Ribeira. A tuberosa que tinha maior contribuição em termos de número de variedades era mandioca 
(Manihot esculenta Crantz) com oito variedades, seguida do inhame (Dioscorea spp.) com seis variedades e da batata-doce (Ipomoea batatas) com três variedades.

Em um levantamento maior, Peroni \& Martins (2000) listaram um total de 24 espécies cultivadas pertencentes a 11 famílias botânicas, totalizando 161 variedades cultivadas em seis unidades de agricultores tradicionais dos municípios de Iguape e Cananéia no Vale do Ribeira. No caso das tuberosas as espécies que apresentavam o maior número de variedades eram a mandioca ( $M$. esculenta Crantz), com 20 variedades, o inhame (Dioscorea spp.) também com 20 variedades, a batata-doce (. batatas) com cinco variedades, o taiá ou taioba (Xanthosoma sagittifolium L. Schott) com duas variedades e a araruta (Maranta arundinacea) e o mangarito (Xanthosoma sp.) com uma variedade.

No ano de 2001, Peroni \& Hanazaki (2002) fizeram um levantamento onde 33 agricultores tradicionais do Vale do Ribeira citaram 261 variedades de 53 espécies. As espécies mais citadas foram a mandioca com 62 variedades seguidas pelo inhame e a batata-doce, ambas com 29 variedades. Desta forma, podemos verificar a importância da cultura do inhame nas roças e na alimentação dos agricultores do Vale do Ribeira. Estudos realizados com etnovariedades de mandioca, inhame e batata-doce coletados nesta região (Sambatti et al., 2001; Peroni, 1998; Briner et al., 2004; Bressan et al., 2004; Veasey et al., 2004) demonstram que os agricultores são mantenedores e geradores de grande repositório de diversidade genética, além de possuírem grande conhecimento a respeito desta diversidade (Peroni \& Martins, 2000).

Segundo Peroni \& Hanazaki (2002), os agricultores tradicionais se interrelacionam nas diferentes unidades evolutivas (roças e comunidades), ou seja, apesar da unidade cultural ser a comunidade, é a família que maneja o nível biológico "roça" e quintais de suas casas que é de ocorrência comum no Vale do Ribeira.

O objetivo deste estudo foi a coleta de germoplasma de inhame (Dioscorea spp.) nas roças e quintais de agricultores tradicionais do Vale do Ribeira, visando a formação de uma coleção ex situ que permitisse a caracterização e avaliação da diversidade genética mantida por esses agricultores. Além disso, procurou-se conhecer a importância dos agricultores tradicionais na manutenção e ampliação dos recursos genéticos de plantas cultivadas e manejadas e o seu papel na conservação "in situ". 


\subsection{Material e Métodos}

O material experimental deste estudo foi coletado através de amostras em roças e quintais de agricultura tradicional autóctone em áreas de Floresta Atlântica no Vale do Ribeira, Estado de São Paulo (Figura 5). A região apresenta clima úmido com temperaturas brandas $\left(28^{\circ} \mathrm{C}\right)$, precipitações variando entre 1.500 a $4.000 \mathrm{~mm} \mathrm{e}$ vegetação formada pela Floresta Ombrófila Densa Atlântica, manguezais e restingas. Esta região foi escolhida segundo levantamento prévio feito por Peroni \& Hanazaki (2002) que indicavam a importância da cultura para os agricultores tradicionais.

Foram realizadas três expedições de coleta de etnovariedades de inhame junto

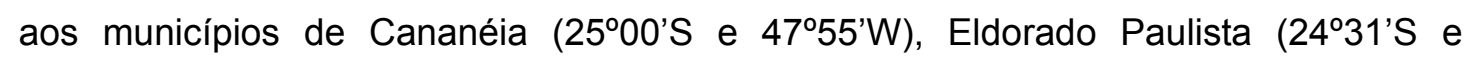
$\left.48^{\circ} 06^{\prime} \mathrm{W}\right)$, Iguape $\left(24^{\circ} 42^{\prime} \mathrm{S}\right.$ e $\left.47^{\circ} 33^{\prime} \mathrm{W}\right)$, Ilha Comprida (245 $53 \mathrm{~S}$ e $47^{\circ} 47^{\prime} \mathrm{W}$ ) e Iporanga

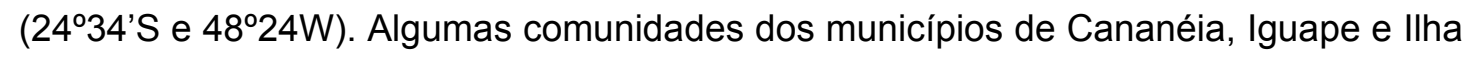
Comprida são consideradas Áreas de Proteção Ambiental (APA) sujeitas às determinações da legislação ambiental vigente no Brasil. No município de Iguape as comunidades que estão no interior das APA's Federal e da Serra do Mar são Icapara, Pontal de Icapara, Praia do Leste e Vila Nova. No município de Cananéia são Agrossolar, São Paulo Bagre, Aroeira, Itapitangui, Porto Cubatão, Prainha, Mandira, Porto do Meio e Santa Maria. Já no município de llha Comprida, está a comunidade de Pedrinhas. A localização dos pontos foi feita através de coordenadas geográficas a partir do Sistema Global de Posicionamento (GPS). O material avaliado não representa a variabilidade genética total da região, mas sim das principais comunidades que mantêm os sistemas agrícolas autóctones. Para tanto, foram estabelecidos critérios de amostragem, visando caracterizar a máxima diversidade genética intra e inter-específica em diferentes níveis hierárquicos: dentro de roças e quintais (unidade básica evolutiva), entre roças e quintais e entre comunidades (unidade cultural) representada por agricultores familiares, caiçaras e quilombolas. Além das comunidades, fizeram-se coletas nas sedes dos municípios visitados (feiras e varejões). 


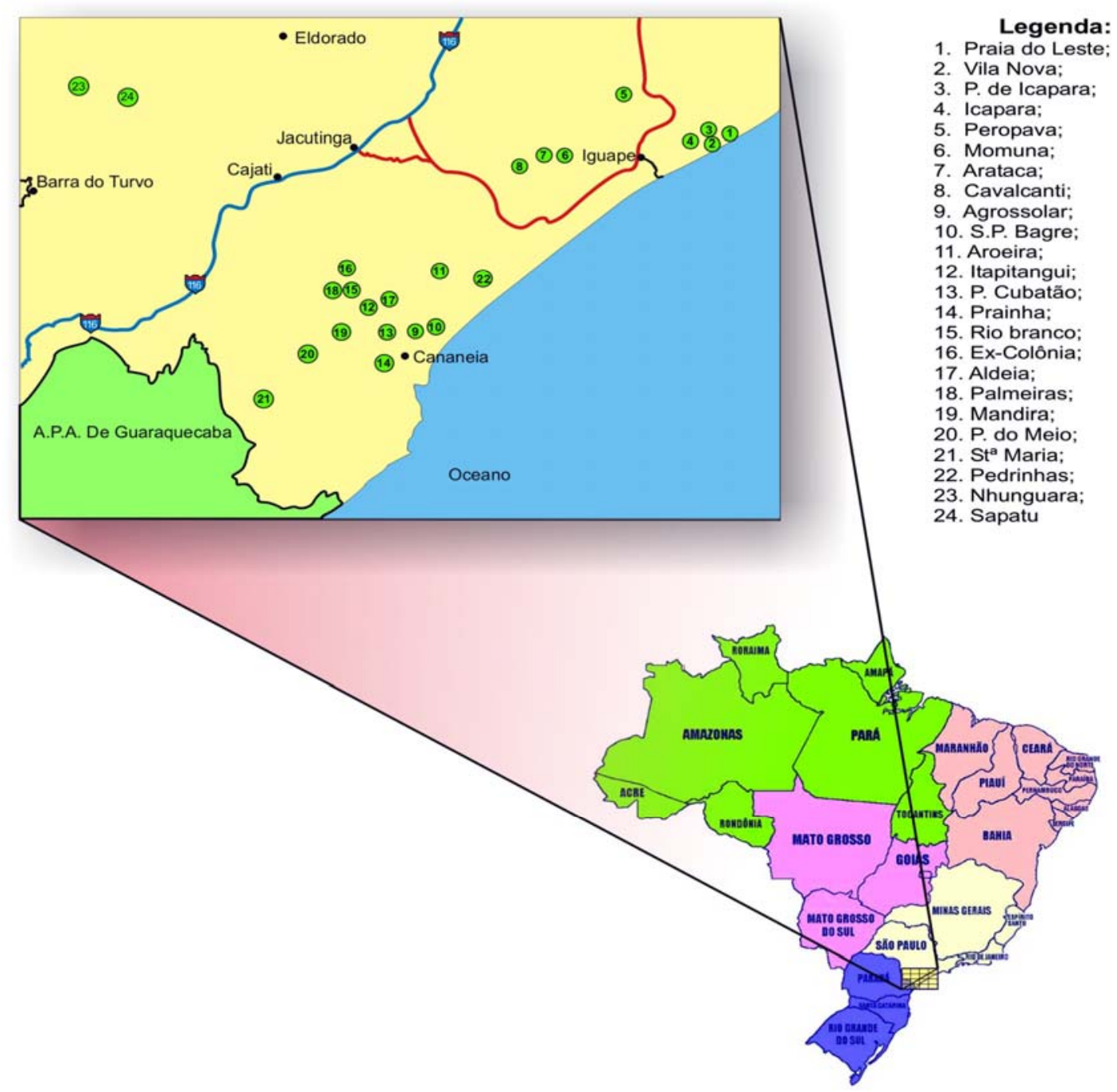

Figura 5 - Comunidades e municípios do Vale do Ribeira visitados por ocasião das coletas de inhame (Dioscorea spp.). Piracicaba-SP, 2005

Foram visitados um total de 91 agricultores que ainda praticam a agricultura de subsistência, caracterizada como agricultura de baixo dispêndio de energia e intenso trabalho familiar. Em cada roça e quintal foi coletado todo material genético (tubérculos) identificado pelos agricultores como diferente. Os materiais coletados (tubérculos) foram trazidos para o Departamento de Genética da Escola Superior de Agricultura "Luiz de Queiroz" da Universidade de São Paulo, em Piracicaba-SP (Tabelas 2, 3, 4 e 5), onde foram multiplicados juntamente com acessos obtidos de 
instituições de pesquisas e materiais comerciais adquiridos em varejões de diferentes regiões do Estado de São Paulo. Os tubérculos foram plantados em vasos e mantidos em casa-de-vegetação em uma primeira etapa de multiplicação e quarentena (Figura $6 \mathrm{~A}$ ). Após dois meses as mudas foram transplantadas para uma área experimental no campo para conservação "ex situ" em fileiras em forma de camalhões (Figura 6B). O espaçamento entre fileiras e entre plantas foi de $1,5 \mathrm{~m}$. Os acessos foram plantados sem repetição, exceto em alguns casos em que mais de um tubérculo foi fornecido pelo agricultor, os quais foram plantados individualmente. Para a condução das plantas utilizaram-se varas de bambu de aproximadamente $1,80 \mathrm{~m}$, visando orientar o crescimento das plantas.
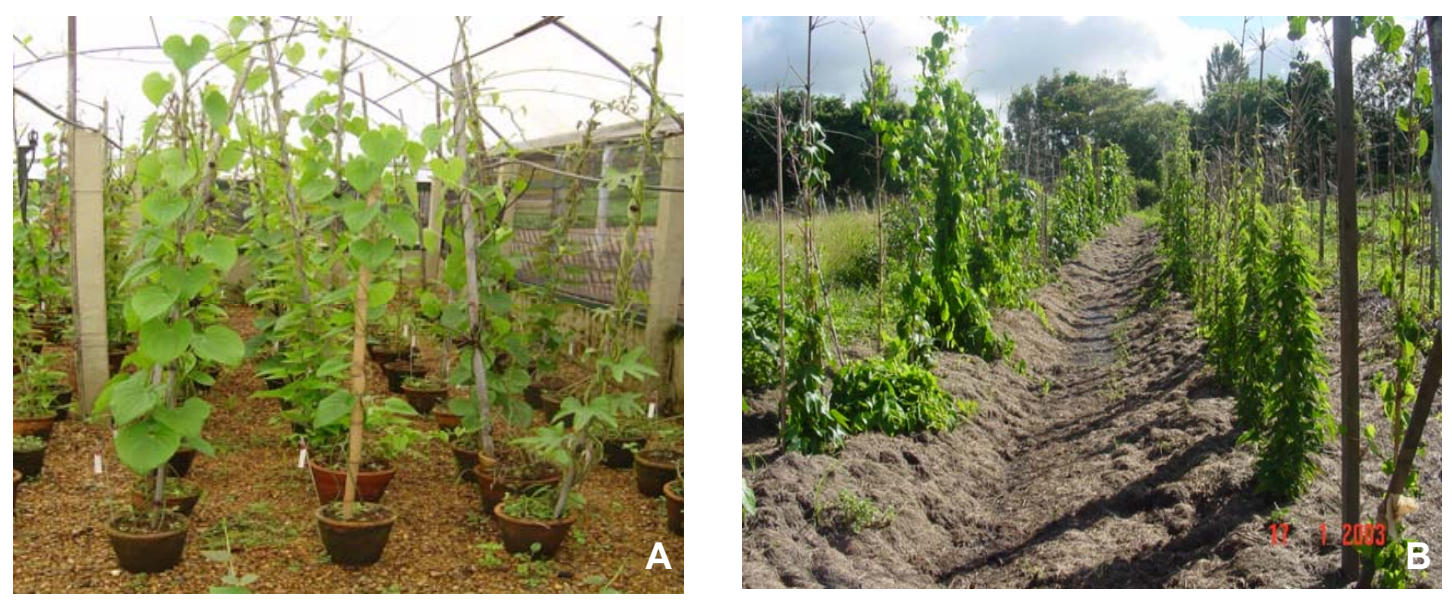

Figura 6 - Plantas de inhame multiplicadas em casa-de-vegetação (A) e em área experimental da ESALQ/USP (B). Piracicaba-SP, 2005 
Tabela 2. Acessos de inhame da espécie D. trifida coletados, com sua respectiva identificação, origem, nomes populares e coordenadas geográficas. Piracicaba-SP, 2005

\begin{tabular}{|c|c|c|c|c|c|c|}
\hline Acessos & Município & Comunidade & Roça & Nome vulgar & \multicolumn{2}{|c|}{ Localização } \\
\hline 1 & Iguape & Icapara & 1 & Cará roxo & $24^{\circ} 40^{\prime} \mathrm{S}$ & $47^{\circ} 27^{\prime} \mathrm{W}$ \\
\hline 2 & Iguape & Icapara & 1 & Cará roxo & $24^{\circ} 40^{\prime} \mathrm{S}$ & $47^{\circ} 27^{\prime} \mathrm{W}$ \\
\hline 3 & Iguape & Icapara & 2 & Cará una & $24^{\circ} 40^{\prime} \mathrm{S}$ & $47^{\circ} 27^{\prime} \mathrm{W}$ \\
\hline 4 & Iguape & Icapara & 2 & Cará roxo & $24^{\circ} 40^{\prime} \mathrm{S}$ & $47^{\circ} 27^{\prime} \mathrm{W}$ \\
\hline 5 & Iguape & Icapara & 2 & Cará branco & $24^{\circ} 40^{\prime} \mathrm{S}$ & $47^{\circ} 27^{\prime} \mathrm{W}$ \\
\hline 6 & Iguape & Icapara & 2 & Cará branco & $24^{\circ} 40^{\prime} \mathrm{S}$ & $47^{\circ} 27^{\prime} \mathrm{W}$ \\
\hline 7 & Iguape & Momuna & 3 & Cará roxo & $24^{\circ} 42^{\prime} \mathrm{S}$ & $47^{\circ} 40^{\prime} W$ \\
\hline 8 & Iguape & Momuna & 3 & Cará roxo & $24^{\circ} 42^{\prime} \mathrm{S}$ & $47^{\circ} 40^{\prime} \mathrm{W}$ \\
\hline 9 & Iguape & Momuna & 4 & Cará S. João & $24^{\circ} 42^{\prime} \mathrm{S}$ & $47^{\circ} 40^{\prime} \mathrm{W}$ \\
\hline 10 & Iguape & Momuna & 5 & Cará S. J. roxo & $24^{\circ} 42^{\prime} \mathrm{S}$ & $47^{\circ} 40^{\prime} \mathrm{W}$ \\
\hline 11 & Iguape & Momuna & 6 & Cará branco & $24^{\circ} 42^{\prime} \mathrm{S}$ & $47^{\circ} 40^{\prime} \mathrm{W}$ \\
\hline 12 & Iguape & Momuna & 7 & Cará peludinho & $24^{\circ} 42^{\prime} \mathrm{S}$ & $47^{\circ} 40^{\prime} \mathrm{W}$ \\
\hline 13 & Iguape & Momuna & 8 & Cará branco & $24^{\circ} 42^{\prime} \mathrm{S}$ & $47^{\circ} 40^{\prime} \mathrm{W}$ \\
\hline 14 & Iguape & Momuna & 9 & Cará S. J. roxo & $24^{\circ} 42^{\prime} \mathrm{S}$ & $47^{\circ} 40^{\prime} \mathrm{W}$ \\
\hline 15 & Iguape & Cavalcanti & 10 & Cará indaiá & $24^{\circ} 42^{\prime} \mathrm{S}$ & $47^{\circ} 41^{\prime} \mathrm{W}$ \\
\hline 16 & Iguape & Arataca & 11 & Cará indaiá & $24^{\circ} 43^{\prime} \mathrm{S}$ & $47^{\circ} 45^{\prime} W$ \\
\hline 17 & Cananéia & Itapitangui & 12 & Cará branco & $24^{\circ} 56^{\prime} \mathrm{S}$ & $47^{\circ} 57^{\prime} \mathrm{W}$ \\
\hline 18 & Cananéia & Rio Branco & 13 & Cará branco & $24^{\circ} 54^{\prime} \mathrm{S}$ & $48^{\circ} 00^{\prime} W$ \\
\hline 19 & Cananéia & Ex-Colônia & 14 & Cará roxo & $24^{\circ} 52^{\prime} \mathrm{S}$ & $48^{\circ} 00^{\prime} \mathrm{W}$ \\
\hline 20 & Cananéia & Palmeiras & 15 & Cará roxo & $24^{\circ} 54^{\prime} \mathrm{S}$ & $48^{\circ} 01^{\prime} W$ \\
\hline 21 & Cananéia & Palmeiras & 15 & Cará branco & $24^{\circ} 54^{\prime} \mathrm{S}$ & $48^{\circ} 01^{\prime} W$ \\
\hline 22 & Cananéia & Palmeiras & 15 & Cará roxo & $24^{\circ} 54^{\prime} \mathrm{S}$ & $48^{\circ} 01^{\prime} W$ \\
\hline 23 & Cananéia & Mandira & 16 & Cará roxo & $24^{\circ} 59^{\prime} \mathrm{S}$ & $48^{\circ} 51^{\prime} W$ \\
\hline 24 & Cananéia & Santa Maria & 17 & Cará pipa & $25^{\circ} 04^{\prime} \mathrm{S}$ & $48^{\circ} 08^{\prime} W$ \\
\hline 25 & Cananéia & Santa Maria & 17 & Cará roxo & $25^{\circ} 04^{\prime} \mathrm{S}$ & $48^{\circ} 08^{\prime} W$ \\
\hline
\end{tabular}


Tabela 3. Acessos de inhame da espécie $D$. bulbifera coletados, com sua respectiva identificação, origem, nomes populares e coordenadas geográficas. Piracicaba-SP, 2005

\begin{tabular}{|c|c|c|c|c|c|c|}
\hline Acessos & Município & Comunidade & Roça & Nome vulgar & \multicolumn{2}{|c|}{ Localização } \\
\hline 1 & Iguape & Momuna & 1 & Cará moela & $24^{\circ} 42^{\prime} \mathrm{S}$ & $47^{\circ} 40^{\prime} \mathrm{W}$ \\
\hline 2 & Iguape & Momuna & 2 & Cará moela & $24^{\circ} 42^{\prime} \mathrm{S}$ & $47^{\circ} 40^{\prime} \mathrm{W}$ \\
\hline 3 & Iguape & Momuna & 3 & Cará moela & $24^{\circ} 42^{\prime} \mathrm{S}$ & $47^{\circ} 40^{\prime} \mathrm{W}$ \\
\hline 4 & Iguape & Cavalcanti & 4 & Cará moela & $24^{\circ} 42^{\prime} \mathrm{S}$ & $47^{\circ} 41^{\prime} \mathrm{W}$ \\
\hline 5 & Iguape & Peropava & 5 & Cará moela & $24^{\circ} 36^{\prime} \mathrm{S}$ & $47^{\circ} 35^{\prime} \mathrm{W}$ \\
\hline 6 & Iguape & Peropava & 5 & Cará moela & $24^{\circ} 36^{\prime} \mathrm{S}$ & $47^{\circ} 35^{\prime} \mathrm{W}$ \\
\hline 7 & Iguape & Peropava & 5 & Cará moela & $24^{\circ} 36^{\prime} \mathrm{S}$ & $47^{\circ} 35^{\prime} \mathrm{W}$ \\
\hline 8 & Iguape & Peropava & 5 & Cará moela & $24^{\circ} 36^{\prime} \mathrm{S}$ & $47^{\circ} 35^{\prime} \mathrm{W}$ \\
\hline 9 & Iguape & Peropava & 5 & Cará moela & $24^{\circ} 36^{\prime} \mathrm{S}$ & $47^{\circ} 35^{\prime} \mathrm{W}$ \\
\hline 10 & Iguape & Peropava & 5 & Cará moela & $24^{\circ} 36^{\prime} \mathrm{S}$ & $47^{\circ} 35^{\prime} \mathrm{W}$ \\
\hline 11 & Iguape & Peropava & 5 & Cará moela & $24^{\circ} 36^{\prime} \mathrm{S}$ & $47^{\circ} 35^{\prime} \mathrm{W}$ \\
\hline 12 & Iguape & Peropava & 6 & Cará (CEASA) & $24^{\circ} 36^{\prime} \mathrm{S}$ & $47^{\circ} 35^{\prime} \mathrm{W}$ \\
\hline 13 & Campinas (IAC) & ** & 7 & Híbrido & $22^{\circ} 53^{\prime} \mathrm{S}$ & $47^{\circ} 04^{\prime} \mathrm{W}$ \\
\hline 14 & Campinas (IAC) & ** & 7 & Híbrido & $22^{\circ} 53^{\prime} \mathrm{S}$ & $47^{\circ} 04^{\prime} \mathrm{W}$ \\
\hline 15 & Campinas (IAC) & ** & 7 & Híbrido & $22^{\circ} 53^{\prime} \mathrm{S}$ & $47^{\circ} 04^{\prime} \mathrm{W}$ \\
\hline 16 & Campinas (IAC) & ** & 7 & Áspero normal & $22^{\circ} 53^{\prime} \mathrm{S}$ & $47^{\circ} 04^{\prime} \mathrm{W}$ \\
\hline 17 & Campinas (IAC) & ** & 7 & Áspero normal & $22^{\circ} 53^{\prime} \mathrm{S}$ & $47^{\circ} 04^{\prime} \mathrm{W}$ \\
\hline 18 & S. João del Rei & ** & 8 & Cará moela & $21^{\circ} 08^{\prime} \mathrm{S}$ & $44^{\circ} 15^{\prime} \mathrm{W}$ \\
\hline 19 & Cananéia & Agrossolar & 9 & Cará paquera & $24^{\circ} 58^{\prime} \mathrm{S}$ & $47^{\circ} 54^{\prime} \mathrm{W}$ \\
\hline 20 & Cananéia & Aroeira & 10 & Cará moela & $24^{\circ} 52^{\prime} \mathrm{S}$ & $47^{\circ} 52^{\prime} \mathrm{W}$ \\
\hline 21 & Cananéia & P. Cubatão & 11 & Cará moela & $24^{\circ} 58^{\prime} \mathrm{S}$ & $47^{\circ} 56^{\prime} \mathrm{W}$ \\
\hline 22 & Cananéia & Prainha & 12 & Cará moela & $25^{\circ} 00^{\prime} \mathrm{S}$ & $47^{\circ} 56^{\prime} \mathrm{W}$ \\
\hline 23 & Cananéia & Prainha & 12 & Cará preto & $25^{\circ} 00^{\prime} \mathrm{S}$ & $47^{\circ} 56^{\prime} \mathrm{W}$ \\
\hline
\end{tabular}

${ }^{* *}$ Materiais comerciais.

O campo de conservação ex situ foi instalado com os materiais da primeira expedição de coleta no mês de setembro de 2003. Após a colheita dos tubérculos, formaram-se novas mudas que foram mantidas novamente em casa-de-vegetação e em seguida plantadas em novo campo, em novembro de 2003 , juntamente com o material coletado durante a segunda expedição de coleta em Cananéia em setembro de 2003. O terceiro campo de conservação foi instalado em novembro de 2004 com os materiais das três coletas seguindo os mesmos procedimentos dos anos anteriores. 
Tabela 4. Acessos de inhame da espécie $D$. alata coletados, com sua respectiva identificação, origem, nomes populares e coordenadas geográficas. Piracicaba-SP, 2005

\begin{tabular}{|c|c|c|c|c|c|c|}
\hline Acessos & Município & Comunidade & Roça & Nome vulgar & \multicolumn{2}{|c|}{ Localização } \\
\hline 1 & Iguape & Icapara & 1 & Cará guaçu & $24^{\circ} 40^{\prime} \mathrm{S}$ & $47^{\circ} 27^{\prime} \mathrm{W}$ \\
\hline 2 & Iguape & Icapara & 2 & Cará aipim & $24^{\circ} 41^{\prime} \mathrm{S}$ & $47^{\circ} 27^{\prime} \mathrm{W}$ \\
\hline 3 & Iguape & Momuna & 3 & Cará branco & $24^{\circ} 42^{\prime} \mathrm{S}$ & $47^{\circ} 40^{\prime} \mathrm{W}$ \\
\hline 4 & Iguape & Momuna & 4 & Cará aipim & $24^{\circ} 42^{\prime} \mathrm{S}$ & $47^{\circ} 40^{\prime} \mathrm{W}$ \\
\hline 5 & Iguape & Arataca & 5 & Cará guaçu & $24^{\circ} 43^{\prime} \mathrm{S}$ & $47^{\circ} 45^{\prime} \mathrm{W}$ \\
\hline 6 & Iguape & Peropava & 6 & Cará (Ceasa) & $24^{\circ} 36^{\prime} \mathrm{S}$ & $47^{\circ} 35^{\prime} \mathrm{W}$ \\
\hline 7 & Iguape & $* *$ & 7 & ** & $24^{\circ} 42^{\prime} \mathrm{S}$ & $47^{\circ} 33^{\prime} \mathrm{W}$ \\
\hline 8 & Iguape & ** & 7 & ** & $24^{\circ} 42^{\prime} \mathrm{S}$ & $47^{\circ} 33^{\prime} \mathrm{W}$ \\
\hline 9 & Iguape & ** & 7 & ** & $24^{\circ} 42^{\prime} \mathrm{S}$ & $47^{\circ} 33^{\prime} \mathrm{W}$ \\
\hline 10 & Iguape & ** & 7 & ** & $24^{\circ} 42^{\prime} \mathrm{S}$ & $47^{\circ} 33^{\prime} \mathrm{W}$ \\
\hline 11 & $\mathrm{St}^{\mathrm{a}}$ Rosa & ** & 8 & ** & $21^{\circ} 28^{\prime} \mathrm{S}$ & $47^{\circ} 21^{\prime} \mathrm{W}$ \\
\hline 12 & St ${ }^{a}$ Rosa & ** & 8 & ** & $21^{\circ} 28^{\prime} \mathrm{S}$ & $47^{\circ} 21^{\prime} \mathrm{W}$ \\
\hline 13 & St ${ }^{a}$ Rosa & ** & 8 & ** & $21^{\circ} 28^{\prime} \mathrm{S}$ & $47^{\circ} 21^{\prime} \mathrm{W}$ \\
\hline 14 & St ${ }^{a}$ Rosa & ** & 8 & ** & $21^{\circ} 28^{\prime} \mathrm{S}$ & $47^{\circ} 21^{\prime} \mathrm{W}$ \\
\hline 15 & Araras & ** & 9 & ** & $22^{\circ} 21^{\prime} \mathrm{S}$ & $47^{\circ} 23^{\prime} \mathrm{W}$ \\
\hline 16 & Araras & ** & 9 & ** & $22^{\circ} 21^{\prime} \mathrm{S}$ & $47^{\circ} 23^{\prime} \mathrm{W}$ \\
\hline 17 & Piracicaba 1 & ** & 10 & ** & $22^{\circ} 42^{\prime} \mathrm{S}$ & $47^{\circ} 38^{\prime} \mathrm{W}$ \\
\hline 18 & Piracicaba 1 & ** & 10 & ** & $22^{\circ} 42^{\prime} \mathrm{S}$ & $47^{\circ} 38^{\prime} \mathrm{W}$ \\
\hline 19 & Matão & ** & 11 & ** & $21^{\circ} 36^{\prime} \mathrm{S}$ & $48^{\circ} 22^{\prime} \mathrm{W}$ \\
\hline 20 & Matão & ** & 11 & ** & $21^{\circ} 36^{\prime} \mathrm{S}$ & $48^{\circ} 22^{\prime} \mathrm{W}$ \\
\hline 21 & Campinas (IAC) & ** & 12 & ** & $22^{\circ} 53^{\prime} \mathrm{S}$ & $47^{\circ} 04^{\prime} \mathrm{W}$ \\
\hline 22 & Campinas (IAC) & ** & 12 & ** & $22^{\circ} 53^{\prime} \mathrm{S}$ & $47^{\circ} 04^{\prime} \mathrm{W}$ \\
\hline 23 & Piracicaba 2 & ** & 13 & ** & $22^{\circ} 42^{\prime} \mathrm{S}$ & $47^{\circ} 38^{\prime} \mathrm{W}$ \\
\hline 24 & Piracicaba 2 & ** & 13 & ** & $22^{\circ} 42^{\prime} \mathrm{S}$ & $47^{\circ} 38^{\prime} \mathrm{W}$ \\
\hline 25 & Cruz das Almas (EMBRAPA) & $* *$ & 14 & Jibóia & $12^{\circ} 40^{\prime} \mathrm{S}$ & $39^{\circ} 06^{\prime} \mathrm{W}$ \\
\hline 26 & Cananéia & Aroeira & 15 & São João & $24^{\circ} 52^{\prime} \mathrm{S}$ & $47^{\circ} 52^{\prime} \mathrm{W}$ \\
\hline 27 & Cananéia & Aroeira & 15 & São J. roxo & $24^{\circ} 52^{\prime} \mathrm{S}$ & $47^{\circ} 52^{\prime} \mathrm{W}$ \\
\hline 28 & Cananéia & P. Cubatão & 16 & Cará (Varejão) & $24^{\circ} 58^{\prime} \mathrm{S}$ & $47^{\circ} 56^{\prime} \mathrm{W}$ \\
\hline 29 & Cananéia & Rio Branco & 17 & São J. roxo & $24^{\circ} 54^{\prime} \mathrm{S}$ & $48^{\circ} 00^{\prime} \mathrm{W}$ \\
\hline 30 & Cananéia & Rio Branco & 17 & São J. branco & $24^{\circ} 54^{\prime} \mathrm{S}$ & $48^{\circ} 00^{\prime} \mathrm{W}$ \\
\hline 31 & Cananéia & Mandira & 18 & Bolo & $24^{\circ} 59^{\prime} \mathrm{S}$ & $48^{\circ} 51^{\prime} \mathrm{W}$ \\
\hline 32 & Cananéia & P. do Meio & 19 & Bolo & $25^{\circ} 00^{\prime} \mathrm{S}$ & $48^{\circ} 04^{\prime} \mathrm{W}$ \\
\hline 33 & Cananéia & $\mathrm{St}^{\mathrm{a}}$ Maria & 20 & Côco & $22^{\circ} 04^{\prime} \mathrm{S}$ & $48^{\circ} 08^{\prime} \mathrm{W}$ \\
\hline 34 & Eldorado & Sapatu & 21 & Cará roxo & $24^{\circ} 36^{\prime} \mathrm{S}$ & $48^{\circ} 22^{\prime} \mathrm{W}$ \\
\hline 35 & Eldorado & Sapatu & 21 & Cará branco & $24^{\circ} 36^{\prime} \mathrm{S}$ & $48^{\circ} 22^{\prime} \mathrm{W}$ \\
\hline
\end{tabular}

** Materiais comerciais. 
Tabela 5. Acessos de inhame da espécie $D$. cayenensis coletados, com sua respectiva identificação, origem, nomes populares e coordenadas geográficas. Piracicaba-SP, 2005

\begin{tabular}{|c|c|c|c|c|c|c|}
\hline Acessos & Município & Comunidade & Roça & Nome vulgar & \multicolumn{2}{|c|}{ Localização } \\
\hline 1 & Iguape & Icapara & 1 & Cará espinho & $24^{\circ} 40^{\prime} \mathrm{S}$ & $47^{\circ} 27^{\prime} \mathrm{W}$ \\
\hline 2 & Iguape & Praia do Leste & 2 & Cará espinho & $24^{\circ} 41^{\prime} \mathrm{S}$ & $47^{\circ} 27^{\prime} \mathrm{W}$ \\
\hline 3 & Iguape & Vila Nova & 3 & Cará espinho & $24^{\circ} 42^{\prime} \mathrm{S}$ & $47^{\circ} 40^{\prime} \mathrm{W}$ \\
\hline 4 & Iguape & Momuna & 4 & Cará espinho & $24^{\circ} 42^{\prime} \mathrm{S}$ & $47^{\circ} 40^{\prime} \mathrm{W}$ \\
\hline 5 & Iguape & Momuna & 4 & Cará espinho & $24^{\circ} 42^{\prime} \mathrm{S}$ & $47^{\circ} 41^{\prime} \mathrm{W}$ \\
\hline 6 & Iguape & Momuna & 5 & Cará espinho & $24^{\circ} 36^{\prime} \mathrm{S}$ & $47^{\circ} 35^{\prime} \mathrm{W}$ \\
\hline 7 & Iguape & Momuna & 6 & Cará espinho & $24^{\circ} 42^{\prime} \mathrm{S}$ & $47^{\circ} 33^{\prime} \mathrm{W}$ \\
\hline 8 & Iguape & Peropava & 7 & Cará espinho & $24^{\circ} 42^{\prime} \mathrm{S}$ & $47^{\circ} 33^{\prime} \mathrm{W}$ \\
\hline 9 & Cananéia & S. P. Bagre & 8 & Cará espinho & $24^{\circ} 57^{\prime} \mathrm{S}$ & $47^{\circ} 53^{\prime} \mathrm{W}$ \\
\hline 10 & Cananéia & S. P. Bagre & 8 & Cará d'angola & $24^{\circ} 57^{\prime} \mathrm{S}$ & $47^{\circ} 53^{\prime} \mathrm{W}$ \\
\hline 11 & Cananéia & Aroeira & 9 & Cará espinho & $24^{\circ} 52^{\prime} \mathrm{S}$ & $47^{\circ} 52^{\prime} \mathrm{W}$ \\
\hline 12 & Cananéia & Rio Branco & 10 & Cará guaçu & $24^{\circ} 54^{\prime} \mathrm{S}$ & $48^{\circ} 00^{\prime} \mathrm{W}$ \\
\hline 13 & Cananéia & Ex-Colônia & 11 & Cará espinho & $24^{\circ} 52^{\prime} \mathrm{S}$ & $48^{\circ} 00^{\prime} W$ \\
\hline 14 & Cananéia & Palmeiras & 12 & Cará espinho & $24^{\circ} 54^{\prime} \mathrm{S}$ & $48^{\circ} 01^{\prime} \mathrm{W}$ \\
\hline 15 & Cananéia & Santa Maria & 13 & Cará guaçu & $25^{\circ} 04^{\prime} \mathrm{S}$ & $48^{\circ} 08^{\prime} \mathrm{W}$ \\
\hline 16 & Ilha Comprida & Pedrinhas & 14 & Cará espinho & $24^{\circ} 53^{\prime} \mathrm{S}$ & $47^{\circ} 40^{\prime} \mathrm{W}$ \\
\hline 17 & Ilha Comprida & Pedrinhas & 14 & Cará espinho & $24^{\circ} 53^{\prime} \mathrm{S}$ & $47^{\circ} 40^{\prime} \mathrm{W}$ \\
\hline 18 & Ilha Comprida & Pedrinhas & 14 & Cará espinho & $24^{\circ} 53^{\prime} \mathrm{S}$ & $47^{\circ} 40^{\prime} \mathrm{W}$ \\
\hline 19 & Iporanga & Nhunguara & 15 & Cará espinho & $24^{\circ} 34^{\prime} \mathrm{S}$ & $48^{\circ} 24^{\prime} \mathrm{W}$ \\
\hline 20 & Eldorado Paulista & Sapatu & 16 & Cará espinho & $24^{\circ} 36^{\prime} \mathrm{S}$ & $48^{\circ} 22^{\prime} \mathrm{W}$ \\
\hline 21 & Eldorado Paulista & Sapatu & 17 & Cará espinho & $24^{\circ} 36^{\prime} \mathrm{S}$ & $48^{\circ} 22^{\prime} \mathrm{W}$ \\
\hline 22 & Cruz das Amas (EMBRAPA) & ** & 18 & exportação & $12^{\circ} 40^{\prime} \mathrm{S}$ & $39^{\circ} 06^{\prime} \mathrm{W}$ \\
\hline 23 & Piracicaba & ** & 19 & Cará do norte & $22^{\circ} 42^{\prime} \mathrm{S}$ & $47^{\circ} 38^{\prime} \mathrm{W}$ \\
\hline
\end{tabular}

Após as introduções no campo de conservação ex situ os acessos foram examinados pela chave de identificação contidas na publicação dos descritores do IPGRI (IPGRI/IITA, 1997) onde verificou-se a presença de cinco espécies. Além disso, os materiais foram caracterizados e avaliados morfologicamente e por marcadores isoenzimáticos visando, conhecer a diversidade mantida e manejada pelos agricultores tradicionais do Vale do Ribeira.

\subsection{Resultados e Discussão}

Quatro espécies de inhame foram coletadas e identificadas nas roças e quintais dos agricultores tradicionais do Vale do Ribeira (Figura 7): D. trifida com os seguintes nomes comuns: cará São João, cará roxo, cará mirim-roxo, cará mirim, cará roxo Indaiá, cará São João roxo, cará São João branco, cará peludinho, cará pipa, cará prato e cará una; $D$. alata (cará guaçu, cará aipim, cará de bolo, cará coco, cará guaçu médio simboá e cará São João mimoso); $D$. bulbifera, que produz tubérculos aéreos e 
é conhecida na região de estudo como "cará moela", "cará paquera" e "cará preto"; e D. cayenensis (cará de espinho, cará guaçu e cará D’angola). A espécie mais cultivada na região é a $D$. trifida, nativa das Américas estando muitas vezes associada à cultura indígena. O nome comum "cará" dado às espécies de Dioscorea spp. pelos agricultores tradicionais da região é originário da língua Tupi-Guarani. Os índios guaranis possuem diversas aldeias no Vale do Ribeira, influenciando desta forma, a cultura local.
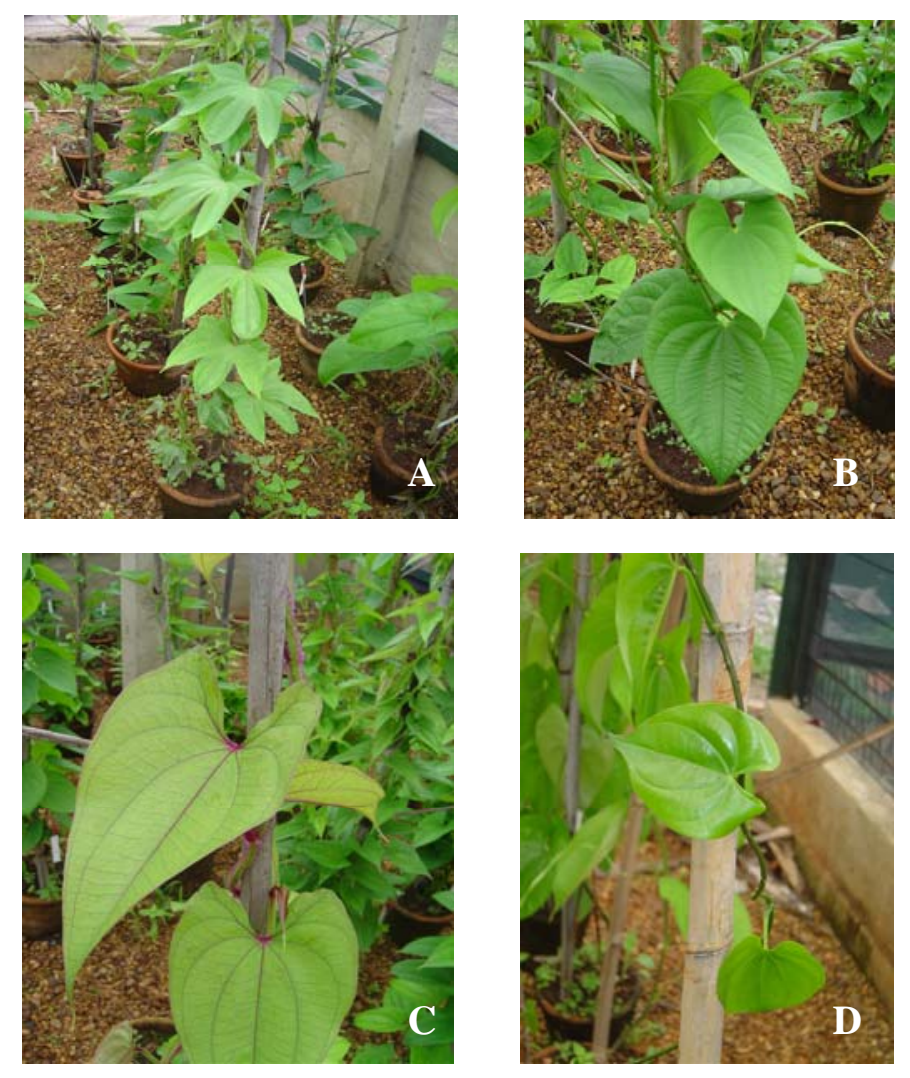

Figura 7 - Espécies de inhame [D. trifida (A), D. bulbifera (B), D. alata (C) e D.cayenensis (D)] coletadas nas roças e quintais dos agricultores tradicionais do Vale do Ribeira. Piracicaba-SP, 2005 
Os nomes comuns para cada espécie estão ligados à classificação e identificação dos agricultores tradicionais, pois é a unidade reconhecida durante o manejo da agrobiodiversidade. Desta forma, o nome atribuído a uma variedade dá sentido ao objeto e permite sua inserção no universo das referências culturais. Contudo, a noção de "variedade" pode encobrir diversos níveis de diversidade biológica dentro de uma mesma comunidade ou região. Outro ponto que chama a atenção é que essa taxonomia é difundida oralmente pelos agricultores durante as trocas de materiais (Mourão \& Nordi, 2002).

A primeira coleta foi realizada em setembro de 2002 nas seguintes comunidades do município de Iguape: Arataca, Cavalcante, Peropava, Momuna, Icapara, Pontal de Icapara, Praia do Leste e Vila Nova. Nesta expedição coletou-se germoplasmas das quatro espécies cultivadas na região: D. trifida $(37,5 \%), D$. alata (16,5\%), D. bulbifera $(18,7 \%)$ e D. cayenensis $(27,3 \%)$.

A segunda viagem de coleta foi realizada em setembro de 2003 nas seguintes comunidades do município de Cananéia: Agrossolar, São Paulo Bagre, Aroeira, Itapitangui, Porto Cubatão, Cananéia (Prainha), Rio Branco, Ex-Colônia, Palmeiras, Mandira, Porto do Meio, Santa Maria e Pedrinhas no município de Ilha Comprida. Na segunda expedição também coletou-se germoplasmas das quatro espécies cultivadas na região: D. trifida $(24,2 \%)$, D. alata $(27,5 \%)$, D. bulbifera $(17,3 \%)$ e $D$. cayenensis $(31,0 \%)$.

$\mathrm{Na}$ comunidade de Prainha observou-se uma agricultora cultivando uma espécie de $D$. bulbifera utilizada para fins medicinais como o controle de diabetes. Este material foi encontrado em um quintal e apresenta tubérculo escuro e córtex amarelo (Figura 8).

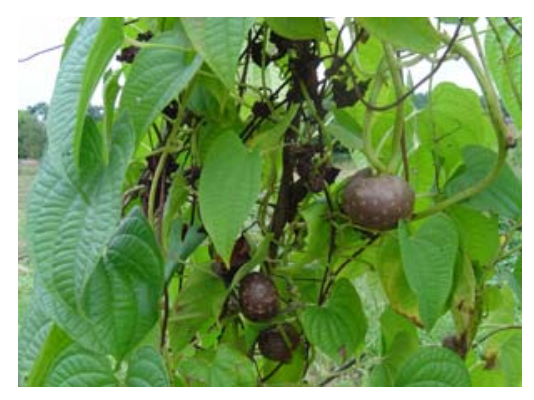

Figura 8 - Tubérculos de D. bulbifera de uso medicinal, coletados em Cananéia Piracicaba-SP, 2005 
A terceira viagem de coleta foi realizada em fevereiro de 2004 nas seguintes comunidades: Nhunguara, no município de Iporanga, e Sapatu no município de Eldorado Paulista. Nesta terceira viagem de coleta visitaram-se roças-de-toco e quintais de agricultores tradicionais quilombolas. Nesta expedição coletou-se germoplasmas das duas principais espécies cultivadas: $D$. alata $(40,0 \%)$ e $D$. cayenensis $(60,0 \%)$.

Visitou-se novamente o município de Iguape em 2004 com o objetivo de buscar as coordenadas das roças e quintais visitados na primeira expedição de coleta na comunidade de Peropava. Observou-se a ausência de parte dos agricultores visitados em 2002 devido às cheias sucessivas no rio Peropava, que causou o abandono gradativo da agricultura tradicional, o que acarretou possivelmente em grandes perdas de germoplasma na região.

O inhame é cultivado pelos agricultores tradicionais nas chamadas "roças-detoco", onde, após a derrubada e queima da mata, os tubérculos são enterrados no solo. Outro local onde os agricultores cultivam o inhame é nos quintais, sendo que em ambos os locais o cultivo se inicia no período das chuvas, aproveitando as condições hídricas da área.

Após a colheita, os inhames são armazenados pelos agricultores tradicionais em suas casas e em leiras no solo, dos quais são retirados aos poucos, segundo suas necessidades alimentares e farmacêuticas. Esses tubérculos também são aproveitados, na época adequada, para o plantio nas roças ou quintais, inteiros ou em pedaços.

O inhame apresenta-se como um material rústico não havendo a necessidade de adubação de cobertura ou mesmo aplicação de produtos químicos para o controle de pragas e doenças. Os únicos tratos culturais exigidos no campo de conservação ex situ foram o preparo dos camalhões, estaqueamento (tutoramento) e capinas freqüentes.

Dos 91 agricultores tradicionais que praticam a agricultura tradicional no Vale do Ribeira, apenas 45 cultivavam o inhame (49,5\%) (Tabela 6). Durante a coleta dos materiais nos roçados, muitos agricultores relataram que outras etnovariedades de inhame eram cultivadas no passado, mas por diversas razões deixaram de ser cultivadas. 
O número médio de etnovariedades por roça coletados para a espécie $D$. trifida foi de 1,5 , para $D$. bulbifera 1,7, para $D$. alata e $D$. cayenensis 1,2. Desta forma, a grande maioria dos agricultores tradicionais do Vale do Ribeira possuem apenas uma etnovariedade de cada espécie. Para todas as espécies juntas o número médio de etnovariedades por roça foi 2,0, ou seja, os agricultores tradicionais cultivam mais de uma espécie mesmo sem fazer esta distinção. Pela Tabela 6 , observa-se que o número médio de espécies por comunidades é 2,0, variando de zero (Pontal de Icapara) a quatro espécies (Momuna).

A coleção de inhame da ESALQ/USP hoje conta com 115 acessos, sendo 85 etnovariedades coletadas no Vale do Ribeira, 20 materiais comerciais adquiridos em varejões, feiras e 10 acessos de instituições de pesquisas como o Instituto Agronômico de Campinas (IAC) e Embrapa Mandioca e Fruticultura de Cruz das Almas (BA) para fins de comparação com as etnovariedades do Vale do Ribeira.

O cultivo do inhame possui a seguinte distribuição nas comunidades do Vale do Ribeirade acordo com a amostragem realizada (Tabela 6); 31\% dos agricultores cultivam o inhame em roças itinerantes e $69 \%$ em quintais. O menor plantio nas roças se deve, provavelmente, à estrutura fundiária da região e à criação das APA's que têm forçado os agricultores a abandonarem as atividades itinerantes. Pois, 60,8\% das comunidades visitadas encontram-se nas APA's Federal e da Serra do Mar sujeitas às determinações da legislação ambiental. Desta forma, a agricultura tradicional passou a ser praticada de modo encoberto na tentativa de evitar possíveis repressões legais. Esses problemas são gerados pela falta de titulação legal das áreas de cultivo, pelas restrições à prática de agricultura como o corte e a queima da vegetação da Floresta Atlântica pela legislação ambiental, além de outros fatores como o êxodo rural e o envelhecimento dos agricultores tradicionais, pois os jovens buscam se engajar no mercado de trabalho das cidades. Nos anos de 1994 e 1995 a idade média dos agricultores tradicionais no Vale do Ribeira levantada por Peroni \& Martins (2000) era de 59 anos. Em um levantamento recente feito por Peroni \& Felipim ${ }^{1}$, os agricultores da mesma região apresentaram idade média de 65 anos.

\footnotetext{
${ }^{1}$ Peroni, N.; Felipim, A. (Departamento de Genética da Escola Superior de Agricultura “Luiz de Queiroz"). Comunicação pessoal.
} 
O inhame é utilizado na alimentação (subsistência) pelos agricultores. Apenas $27 \%$ dos agricultores relataram que o inhame é cultivado com propósito comercial nas feiras e mercados locais e $9 \%$ o utilizam com o propósito medicinal como o controle de diabetes e combate à desnutrição de crianças e idosos.

Tabela 6. Municípios, comunidades, número de agricultores tradicionais visitados (ATV), número de agricultores que cultivam o inhame $(\mathrm{ACl})$, número de etnovariedades de inhame cultivados nas roças (CR) e em quintais (CQ), número de espécies de inhame $(E I)$ e usos do inhame no Vale do Ribeira. Piracicaba-SP, 2005

\begin{tabular}{|c|c|c|c|c|c|c|c|}
\hline Municípios & Comunidades & ATV & $\mathrm{ACl}$ & CR & $\mathrm{CQ}$ & El & Usos $^{1}$ \\
\hline Iguape & Icapara & 11 & 5 & 2 & 3 & 3 & $\mathrm{~S}, \mathrm{C}, \mathrm{M}$ \\
\hline " & Praia do Leste & 3 & 1 & - & 1 & 1 & $S$ \\
\hline “ & Pontal de Icapara & 2 & 0 & - & - & 0 & - \\
\hline “ & Vila Nova & 2 & 1 & - & 1 & 1 & S \\
\hline “ & Momuna & 13 & 8 & 2 & 6 & 4 & $\mathrm{~S}$ \\
\hline “ & Cavalcanti & 3 & 1 & - & 1 & 2 & S \\
\hline “ & Arataca & 3 & 1 & 1 & - & 2 & S, C \\
\hline “ & Peropava & 6 & 3 & 1 & 2 & 3 & S,C \\
\hline Ilha Comprida & Pedrinhas & 4 & 3 & - & 3 & 1 & S \\
\hline Cananéia & Agrossolar & 3 & 1 & 1 & - & 2 & $S$ \\
\hline “ & São Paulo Bagre & 3 & 2 & - & 2 & 1 & S \\
\hline “ & Aroeira & 3 & 3 & - & 3 & 3 & $S$ \\
\hline “ & Itapitangui & 2 & 1 & - & 1 & 1 & S,C \\
\hline “ & Porto Cubatão & 2 & 2 & 1 & 1 & 2 & $\mathrm{~S}$ \\
\hline “ & Prainha & 3 & 1 & - & 1 & 1 & S,M \\
\hline “ & Rio Branco & 4 & 2 & 1 & 1 & 3 & S,C \\
\hline “ & Ex-colônia & 2 & 1 & 1 & - & 2 & $S$ \\
\hline “ & Palmeiras & 2 & 1 & 1 & - & 3 & S,C \\
\hline “ & Mandira & 3 & 2 & - & 2 & 3 & $S$ \\
\hline “ & Porto do Meio & 1 & 1 & - & 1 & 1 & S \\
\hline “ & Santa Maria & 2 & 1 & 1 & - & 3 & $S$ \\
\hline Iporanga & Nhunguara & 6 & 1 & 1 & - & 2 & $S$ \\
\hline Eldorado & Sapatu & 8 & 3 & 1 & 2 & 2 & $S$ \\
\hline Total & 23 & 91 & 45 & 14 & 31 & - & - \\
\hline
\end{tabular}

${ }^{1}$ C - comercial; S - subsistência; M - medicinal. 


\subsection{Conclusões}

Verificou-se nas comunidades do Vale do Ribeira a existência de grande diversidade de etnovariedades e espécies de Dioscorea sob o cultivo dos agricultores tradicionais, os quais possuem grande conhecimento a respeito das peculiaridades de manejo desta diversidade, observando-se também grande variedade de nomes populares atribuídos aos mesmos, bem como diferentes usos na alimentação e medicinal. Contudo, em grande parte das roças visitadas o inhame é cultivado para subsistência dos agricultores.

Observou-se também uma redução na dimensão das áreas de plantio devido, em grande parte, as limitações impostas pela legislação vigente, o que dificulta a oportunidade dos agricultores de manejar e selecionar os materiais vegetais. 


\section{DIVERSIDADE ISOENZIMÁTICA E MORFOLÓGICA DE Dioscorea trifida EM ROÇAS DE AGRICULTURA TRADICIONAL DO VALE DO RIBEIRA - SP}

\section{Resumo}

Os agricultores tradicionais têm se mostrado mantenedores e geradores de diversidade genética de plantas cultivadas como o inhame (Dioscorea spp.) e espécies nativas. O presente estudo teve como objetivo avaliar a diversidade genética de 25 etnovariedades de Dioscorea trifida, por meio de marcadores isoenzimáticos e morfológicos, verificando como esta se distribui nos diferentes níveis de organização, como roças e comunidades do Vale do Ribeira. As etnovariedades foram caracterizadas por meio de marcadores isoenzimáticos utilizando géis de poliacrilamida (seis sistemas) e amido (um sistema) e por marcadores morfológicos (24 caracteres). Devido à natureza poliplóide do inhame os materiais foram genotipados gerando dados binários. Os dados morfológicos também foram analisados por meio de notas transformados em uma matriz binária. Para ambos os dados foi calculado o índice de similaridade de Jaccard entre pares de indivíduos. A partir dos índices médios de similaridade de Jaccard para variedades, roças e comunidades foram feitos dendrogramas pelo critério de agrupamento UPGMA. Pelas análises de agrupamento houve a formação de dois grandes grupos, sendo que o primeiro agrupou as etnovariedades do município de Iguape e o segundo as de Cananéia para as análises isoenzimáticas. Outro parâmetro analisado foi a correlação entre as matrizes de distância genética e geográfica, verificando-se um valor nulo ( $r=-0,09)$ para isoenzimas, sugerindo que não existe correlação entre esses dois parâmetros e que a distribuição das etnovariedades está ligada a fatores antrópicos. Foi também realizada a análise de variância molecular (AMOVA) e pôde-se verificar que a maior parte da variabilidade isoenzimática encontrava-se entre roças dentro de comunidades $(47,9 \%)$. Para a análise morfológica, os agrupamentos indicaram a formação de três grupos 
onde o resultado mostra a grande influência das unidades culturais sobre os caracteres morfológicos. A correlação entre as distâncias morfológicas e geográficas também indicou que a diversidade não estava estruturada no espaço $(r=0,01)$. De acordo com a AMOVA, a maior parte da variabilidade morfológica encontrava-se dentro de roças dentro de comunidades $(39,0 \%)$. Correlacionando-se as estimativas isoenzimáticas e morfológicas chegou-se a uma correlação positiva $(r=0,21)$, mas não significativa estatisticamente. Em suma, os agricultores tradicionais do Vale do Ribeira manejam grande variabilidade genética em seu sistema agrícola para a cultura do inhame $(D$. trifida), porém em coletas futuras recomenda-se a não estruturação geográfica da mesma, dando-se uma atenção especial para a coleta entre e dentro das roças. 
ISOENZYMATIC AND MORPHOLOGICAL DIVERSITY OF Dioscorea trifida IN SWIDDENS OF TRADITIONAL AGRICULTURE OF THE RIBEIRA RIVER VALLEYSP

\section{Summary}

Traditional agriculturists have been maintainers and generators of genetic diversity of cultivated plants such as the yam (Dioscorea spp.) and other native species. The present study aimed at evaluating the genetic diversity of 25 ethnovarieties of $D$. trifida, using isoenzymatic and morphological markers, verifying how this diversity is distributed in the different levels of organization, such as swiddens and communities of the Ribeira River Valley. For the isozyme analyses, polyacrilamide gel were used for six enzyme systems and starch gels for one system, while for the morphological analyses, 24 characters were evaluated. Due to the polyploid nature of yam, the materials were genotyped by the presence or absence of a band, generating binary data. Morphological data were also transformed into a binary matrix. For both sets of data, the Jaccard similarity indices were obtained between pairs of individuals. From the average Jaccard similarity indices for varieties, swiddens and communities, dendrograms were made by the clustering criterion of UPGMA. Two great groups could be identified in the cluster analyses for the isoenzymatic data, the first one grouping together the ethnovarieties of Iguape municipality and the second the ones of Cananéia. Another parameter analyzed was the correlation between the genetic and geographic distance matrices, with a null value $(r=-0,09)$ identified for the isozymes, indicating the inexistence of correlation between these two parameters and that the distribution of the ethnovarieties was most likely due to anthropic factors. Also, the analysis of molecular variance (AMOVA) showed that most of the isoenzymatic variability occurs among swiddens within communities (47,9\%). For the morphological analyses, the clustering showed the formation of three groups where the results indicate the great influence of the cultural units (communities) on the morphological characters. The correlation between morphological and geographic distances also indicated that the diversity is not structured in space $(r=0.01)$. In accordance to AMOVA, most of the morphological variability was concentrated within swiddens within communities $(39,0 \%)$. Correlating the isoenzymatic and morphological estimates, a positive but not significant value was obtained $(r=0.21)$. Summarizing, traditional 
agriculturists of the Ribeira River Valley manage a great genetic variability in their agricultural system for the yam culture (D. trifida). However, in future collections the non-geographic structuring is recommended, with a special attention given to the collection between and within the swiddens of a few communities. 


\subsection{Introdução}

A história da domesticação das plantas remota a antiguidade onde historicamente o homem nômade consumia plantas silvestres, porém quando este passou a ser sedentário deu início à domesticação dessas espécies, desenvolvendo formas cultivadas particulares nas distintas regiões geográficas, cujas condições favoreciam a diversidade, especiação, gerando culturas típicas da culinária da região. As migrações e explorações das diversas partes do mundo pelo homem trouxeram como conseqüência a disseminação e assimilação das espécies cultivadas por outras etnias, resultando em uma distribuição bastante generalizada das distintas espécies.

Algumas plantas nativas das terras baixas da América do Sul como a mandioca (Manihot esculenta), batata doce (Ipomoea batatas), taioba ou taiá (Xanthosoma sp.), araruta (Maranta arundinacea), cupá (Cissus gongylodes), amendoim (Arachis sp.) e o inhame (Dioscorea trifida) foram domesticadas pelas populações indígenas que também desenvolveram sua culinária baseada nestes produtos.

No Brasil, algumas espécies de inhame foram introduzidas por intermédio dos portugueses, espanhóis e africanos (escravos) entre os séculos 16 e 18. Mas a espécie $D$. trifida foi domesticada pelos povos indígenas que aqui habitavam. No início do século 20, a Comissão Rondon localizou no extremo noroeste do Mato Grosso tribos sem contato com a civilização cultivando o "cará" ( $D$. trifida), onde também o denominavam de "cará mimoso", "cará roxo" e "cará bola". Esses inhames apresentavam coloração de polpa variável, além de serem volumosos e bonitos (Silva, 1971; Abramo, 1990).

No Vale do Ribeira encontramos agricultores tradicionais cultivando esta espécie. Esta região possui uma particularidade, ou seja, a existência de corredores semi-intactos de Mata Atlântica coexistindo com a agricultura tradicional. Esse tipo de agricultura é praticado há milênios e hoje pode ser considerado como parte integrante do ecossistema, pois encontramos diferentes estágios sucessionais na floresta, ou seja, a formação de mosaicos promovendo, desta forma, heterogeneidade das espécies. Esses agricultores possuem uma habilidade de combinação ecológica o que permite manter e gerar diversidade genética de plantas cultivadas como a espécie $D$. trifida. Este tipo de agricultura sobreviveu aos diversos ciclos econômicos que vieram a 
se estabelecer na região, pois o modelo de cultivo está baseado na subsistência, além de ser caracterizado por baixo dispêndio de energia e intenso trabalho familiar.

A análise de isoenzimas vem sendo utilizada desde 1950 com muita eficiência para estimar e avaliar o grau de variabilidade genética em populações naturais e cultivadas, o fluxo gênico, hibridação, relação filogenética, e empregada nos estudos da distribuição da variabilidade genética entre e dentro de roças de etnovariedades de mandioca (Peroni, 1998; Faraldo, 1994, 1999; Sambatti et al, 2001). Desta forma, a análise isoenzimática constitui numa maneira rápida, simples e de alto valor informativo de avaliar genotipicamente muitos locos em um grande número de indivíduos (Smithies, 1955, Faraldo, 1999; Silva, 2000; Faraldo et al, 2002). Mesmo havendo na atualidade técnicas suplementares que ampliam o poder de detecção dos efeitos das mutações ao nível de DNA, a isoenzima continua apresentando um potencial enorme para a genética de plantas (Torggler et al., 1995).

Para a cultura do inhame, observa-se na literatura a caracterização isoenzimática no estudo genético em acessos do complexo $D$. cayenensis-rotundata (Hamon \& Toure, 1990; Zoundjihekpon et al., 1994; Dansi et al., 2000). Os resultados obtidos por Hamon \& Toure (1990) mostraram boa concordância entre o polimorfismo isoenzimático e a variação morfológica para 453 acessos do complexo $D$. cayenensisrotundata. Diferentes padrões de bandas de sete sistemas enzimáticos levaram à identificação de 227 diferentes cultivares, de um total de 467 acessos analisados deste complexo da República de Benin (Dansi et al., 2000). Zoundjihekpon et al. (1994) analisaram progênies obtidas a partir do cruzamento de variedades tetraplóides do complexo $D$. cayenensis-rotundata, observando diversos padrões de segregação para seis sistemas enzimáticos, trazendo informações sobre a genética dos sistemas analisados.

A caracterização morfológica também tem sido utilizada para descrever a variabilidade genética expressa através de descritores qualitativos e quantitativos. Existe uma extensa lista de descritores, preconizados pelo IPGRI e International Institute of Tropical Agriculture (IITA), em Ibadan, Nigéria, tanto morfológicos como agronômicos que podem ser empregados para a caracterização da diversidade das espécies de inhame (IPGRI/IITA, 1997). Onyilagha (1986) avaliou 14 acessos de D. rotundata utilizando 40 caracteres morfológicos, sendo que a análise de componentes principais mostrou que os caracteres com maior poder discriminatório foram: tamanho 
da folha, tamanho do tubérculo, cor do tubérculo, número de espiguetas florais por nó, e comprimento da espigueta. Rhodes \& Martin (1972) utilizaram 100 caracteres para estudar a variação em 30 cultivares de $D$. alata, concluindo que apenas 28 foram úteis para a classificação dos cultivares.

Com o objetivo de estimar a diversidade genética, por meio de marcadores isoenzimáticos e morfológicos, em etnovariedades de $D$. trifida cultivadas por agricultores tradicionais no Vale do Ribeira, buscou-se responder as seguintes questões: (1) existe variabilidade genética entre as etnovariedades para marcadores isoenzimáticos?; (2) existe variabilidade genética entre as etnovariedades para descritores morfológicos? (3) se afirmativas ambas as questões (1) e (2), como esta se distribui nos diferentes níveis de organização, como roças e comunidades do Vale do Ribeira?; (4) existe correlação entre as distâncias genéticas, tanto para marcadores isoenzimáticos como morfológicos, e as distâncias geográficas?; (5) existe correlação entre as distâncias genéticas baseadas em dados isoenzimáticos e morfológicos?

\subsection{Material e Métodos}

Foram coletadas 25 etnovariedades de $D$. trifida junto aos municípios de

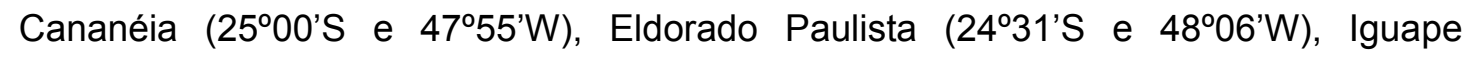

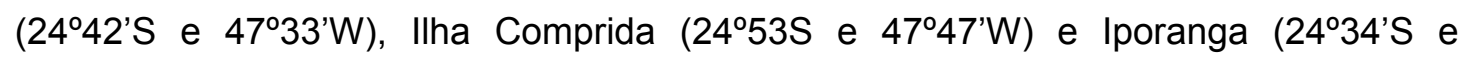
$48^{\circ} 24 \mathrm{~W}$ ) (Tabela 2; Figura 5), provenientes de roças e quintais cultivados por agricultores tradicionais do Vale do Ribeira.

Convencionou-se para as análises que as unidades básicas evolutivas roças e quintais serão analisadas apenas como "roça", pois em ambos os locais são as famílias que manejam os materiais biológicos.

Coletou-se um tubérculo de cada roça, com exceção das roças 1 e 2 da comunidade de Icapara, roça 3 em Momuna, roça 15 em Palmeiras e roça 17 em Santa Maria que possuíam mais de uma etnovariedade identificada como diferente pelo agricultor. Desta forma, o número médio de etnovariedades coletadas por roça foi de 1,5. Esses materiais foram trazidos para o Departamento de Genética da Escola Superior de Agricultura "Luiz de Queiroz" da Universidade de São Paulo, em Piracicaba-SP $\left(22^{\circ} 43^{\prime} \mathrm{S}\right.$ e $\left.47^{\circ} 43^{\prime} \mathrm{W}\right)$ e plantados em vasos e mantidos em casa-devegetação em uma primeira etapa de brotação e quarentena. Dois meses após, as 
mudas foram transplantadas para um campo experimental em camalhões, sem repetição. O espaçamento entre fileiras e entre plantas foi de 1,50 m. Para a condução das plantas utilizaram-se varas de bambu de aproximadamente $1,80 \mathrm{~m}$, visando orientar o crescimento das plantas. Foi originado, desta forma, o banco de germoplasma de conservação ex situ de D. trifida do Laboratório de Ecologia Evolutiva e Genética Aplicada (LEEGA).

Esses acessos foram analisados por meio de marcadores isoenzimáticos e morfológicos, visando verificar como se distribui a diversidade genética nos diferentes níveis hierárquicos: dentro de roças e quintais (unidade básica evolutiva), entre roças e quintais dentro de comunidades (unidade cultural) e entre comunidades.

\subsubsection{Análise isoenzimática}

Para a caracterização e avaliação da diversidade isoenzimática de $D$. trifida, cultivada pelos agricultores tradicionais, foi utilizada a técnica de eletroforese que é baseada na migração de formas alternativas de uma mesma enzima (Soltis \& Soltis, 1990; Silva, 2000) (Figura 9).

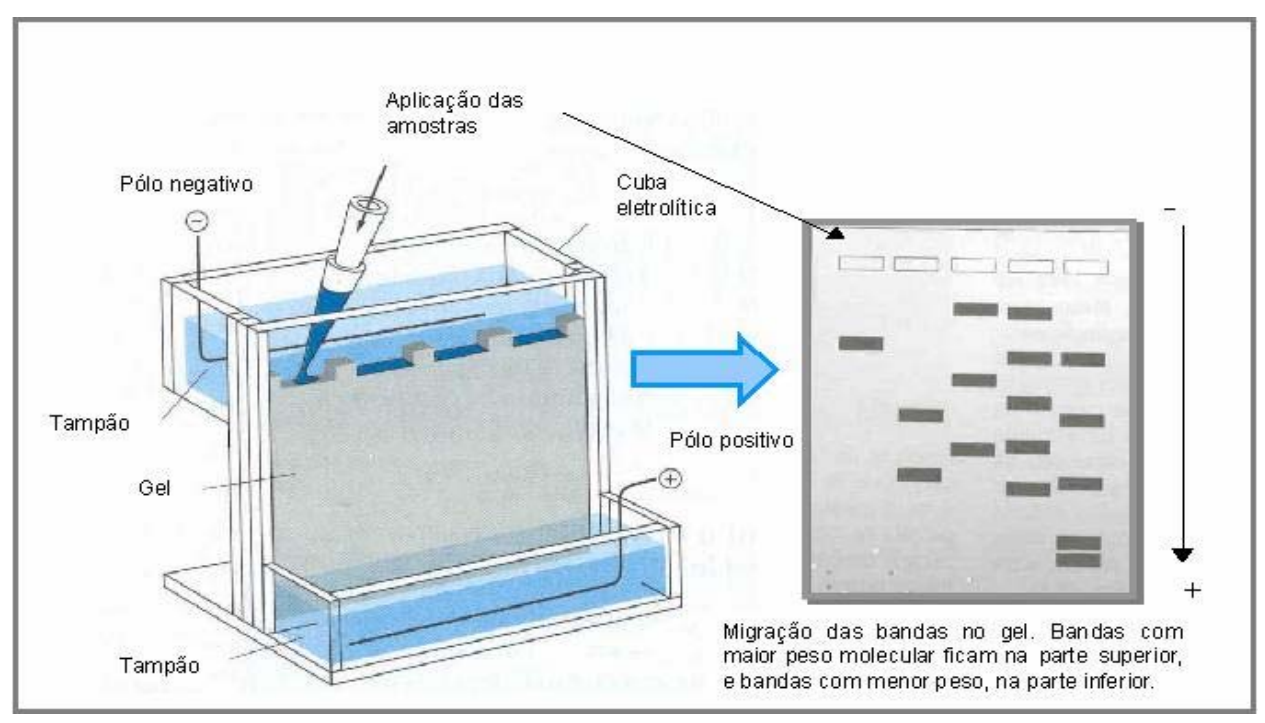

Fonte: EMBRAPA (2004).

Figura 9 - Técnica de eletroforese de isoenzimas 
Em uma etapa preliminar buscou-se adaptar o protocolo de eletroforese de isoenzimas em gel de poliacrilamida (sistema descontínuo) e gel de amido (Mignouna et al., 2002; Alfenas et al., 1991) para a cultura do inhame (Figura 10). Após a adaptação da metodologia, procedeu-se a avaliação genética com base nos padrões isoenzimáticos.

\subsubsection{Extração das enzimas}

As enzimas foram extraídas a partir de amostras de folhas jovens (recém expandidas) de plantas adultas (6-8 meses) (Figura 11A) do banco de germoplasma da USP/ESALQ, as quais foram pesadas $(0,2 \mathrm{~g})$ e maceradas em nitrogênio líquido $\left(-96^{\circ} \mathrm{C}\right)$ em microtubos de 1,5 mL (Ferreira \& Grattapaglia, 1998). Foi utilizado $1 \mathrm{~mL}$ de solução extratora, descrita por Mignouna et al. (2002) acrescida de $3 \%$ de mercaptoetanol, visando minimizar os danos da oxidação (Figura 11B).

Mesmo com a utilização de substâncias como o mercaptoetanol que reduzem a reação dos compostos fenólicos com as enzimas, estes são rapidamente oxidados pela ação de fenoloxidases, muito ativas nos tecidos do inhame. Oliveira et al. (2002), trabalhando com tecidos foliares de batata-doce, também sofreu com os processos de oxidação do material pela ação das fenoloxidases. O macerado resultante foi centrifugado a $15.000 \mathrm{rpm}(23.000 \mathrm{~g})$ por 20 minutos em centrifuga refrigerada a $4^{\circ} \mathrm{C}$ (Figura 12). 

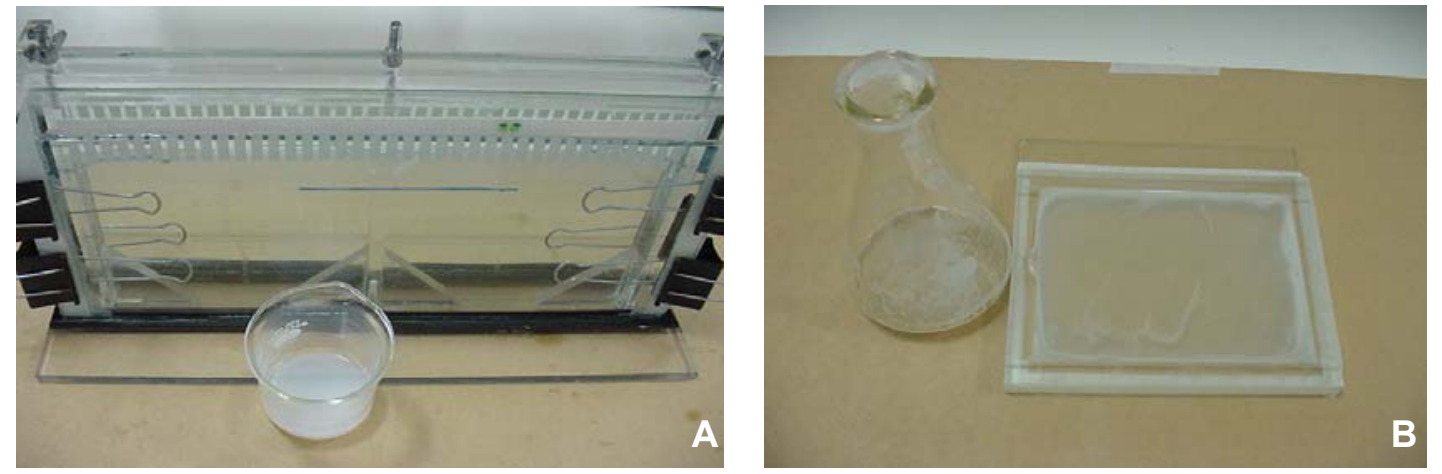

Figura 10 - Placas de geis de poliacrilamida (sistema descontínuo) (A) e amido (B). Piracicaba-SP, 2005
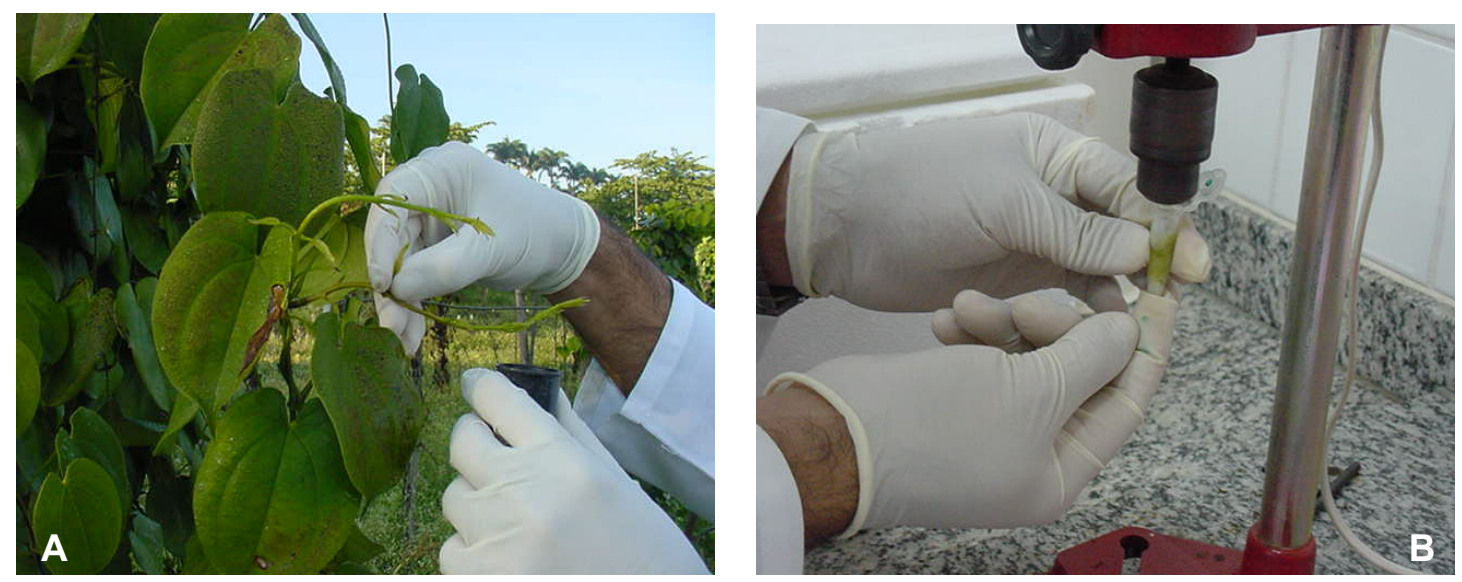

Figura 11 - Coleta de folhas jovens (A) e processo de extração de enzimas (B), em inhame (Dioscorea spp.). Piracicaba-SP, 2005

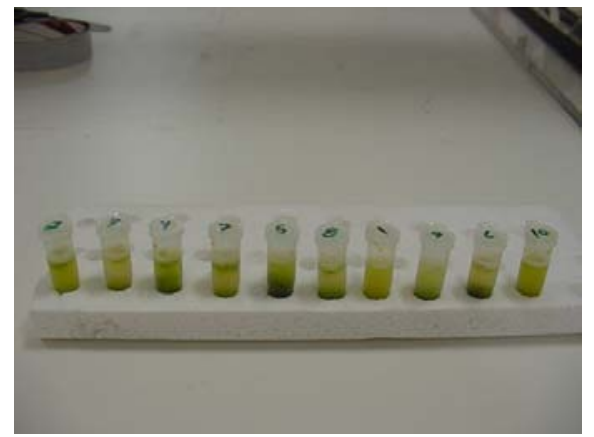

Figura 12 - Extratos enzimáticos de inhame (Dioscorea spp.) obtidos após a centrifugação. Piracicaba-SP, 2005 
Para o gel de poliacrilamida, foi utilizado nas canaletas do gel polimerizado, uma alíquota de $25 \mu \mathrm{L}$ do extrato bruto (sobrenadante) misturado com $250 \mu \mathrm{L}$ de solução de azul de bromofenol $\left(0,01 \mathrm{~g}\right.$ de azul de bromofenol/1.000mL de $\mathrm{H}_{2} \mathrm{O}$ destilada), o qual serviu como parâmetro para a avaliação da migração das proteínas no gel. No caso do gel de amido, o sobrenadante era absorvido por pedaços de papel de filtro Whatmann $\mathrm{n}^{\circ} 3$, com dimensões de $4 \mathrm{~mm}$ por $1,7 \mathrm{~mm}$. Estes papéis foram colocados verticalmente no gel (lado a lado). Nas extremidades foram colocados papéis embebidos na solução de azul de bromofenol $(0,01 \mathrm{~g}$ de azul de bromofenol/1.000mL de $\mathrm{H}_{2} \mathrm{O}$ destilada), o qual também serviu como parâmetro para a avaliação da migração das proteínas no gel. O restante do sobrenadante foi descartado devido à rápida degradação das enzimas do inhame, mesmo quando o sobrenadante era congelado e armazenado em freezer $\left(-20^{\circ} \mathrm{C}\right)$.

\subsubsection{Preparação dos géis}

Os géis de amido foram preparados com uma mistura de Sacarose (12g), Penetrose $30(25,72 \mathrm{~g})$ e Amido Sigma $(13,72 \mathrm{~g})$. O melhor tampão gel/eletrodo para o gel de amido foi o sistema Tris-citrato para o sistema enzimático utilizado (Soltis et al., 1983). O gel era preparado aquecendo-se a mistura de sacarose, penetrose, amido e tampão Tris-citrato em um kitassato por cinco minutos em forno microondas. A cada 30 segundos o aquecimento era interrompido para agitação visando a homogeneização da mistura. Após três fervuras a mistura era colocada numa placa de vidro com barras de acrílico formando uma moldura de $15,5 \times 13 \times 1,3 \mathrm{~cm}$ (Figura 10B) e resfriado a temperatura ambiente por cerca de uma hora antes de ser coberto com filme plástico e levado a geladeira por oito horas.

Para os géis de poliacrilamida em sistema descontínuo a migração das enzimas ocorre devido a influência de um campo elétrico através de dois géis, o concentrador e o separador. Os géis, separador e concentrador, apresentam diferentes composições quanto ao $\mathrm{pH}$ e concentração de acrilamida. O gel separador foi preparado em um $\mathrm{pH}$ de 8,9 e $7 \%$ de acrilamida; já o concentrador com um pH de 6,9 e $2 \%$ de acrilamida. $\mathrm{O}$ primeiro gel a ser vertido na placa era o separador o qual ocupava dois terços do volume total. Adicionava-se, em seguida, $2,0 \mathrm{~mL}$ de álcool isopropílico, cujo objetivo é evitar o contato entre o ar atmosférico e o gel separador, formando uma linha uniforme 
ao longo do gel facilitando, desta forma, o contato com o gel concentrador. A polimerização do gel separador ocorria em 15 minutos. O gel concentrador tem a função de organizar as proteínas conforme o tamanho da carga, pois apresenta os poros maiores que o gel separador. Neste gel a eletroforese é realizada em menor voltagem.

Para a migração das enzimas, o gel de amido era mantido em um balcão frigorífico $\left(4^{\circ} \mathrm{C}\right)$ com corrente constante de $20 \mathrm{~mA}$ durante os primeiros 30 minutos, quando os papeis de filtro eram retirados. Após esse período a corrente era alterada para $40 \mathrm{~mA}$ por 7 horas.

Durante a migração das enzimas o gel de poliacrilamida era também mantido em um balcão frigorífico $\left(4^{\circ} \mathrm{C}\right)$, com corrente constante de 60 Volts durante os primeiros 30 minutos, 120 Volts por mais 30 minutos e 240 Volts por 4 horas.

\subsubsection{Composição dos tampões}

Para o gênero Dioscorea a definição dos protocolos de extração e preparação dos géis foi muito difícil, desta forma a composição dos tampões merece destaque, pois gastou-se meses na definição dos mesmos.

A solução extratora foi constituída da seguinte forma:

$\begin{array}{cl}\text { Tris-HCl 0,1 M pH 7,8 } & 0,242 \mathrm{~g} / \mathrm{L} \\ \mathrm{KCl} 0,1 \mathrm{M} & 0,149 \mathrm{~g} / \mathrm{L} \\ \text { EDTA 0,005 M } & 0,042 \mathrm{~g} / \mathrm{L} \\ \text { Sacarose } & 20 \% \\ \text { Mercaptoetanol } & 3 \%\end{array}$

Os tampões utilizados na confecção do gel de amido e na cuba de corrida tinham a seguinte composição:

\section{- Tampão Tris Citrato (TC) pH 7,0 (eletrodo)}

$$
\begin{array}{cl}
\text { Tris }(0,135 \mathrm{M}) & 16,35 \mathrm{~g} / \mathrm{L} \\
\text { Ácido Cítrico }(0,043 \mathrm{M}) & 9,04 \mathrm{~g} / \mathrm{L}
\end{array}
$$

\section{- Tampão Tris Citrato (TC) pH 7,0 (gel)}

Diluir uma parte do tampão do eletrodo para 14 partes de água destilada.

$\mathrm{Na}$ confecção e durante a corrida dos géis de poliacrilamida foram utilizados os seguintes tampões: 
- Tampão do gel separador

$\begin{array}{cl}\text { Solução A } & 20 \mathrm{~mL} \\ \text { Solução C } & 40 \mathrm{~mL} \\ \mathrm{H}_{2} \mathrm{O} & 100 \mathrm{~mL} \\ \text { Solução E } & 1,1 \mathrm{~mL} \\ \text { Temed } & 50 \mu \mathrm{L}\end{array}$

- Tampão do gel concentrador

$\begin{array}{cl}\text { Solução B } & 2,5 \mathrm{~mL} \\ \text { Solução D } & 5,0 \mathrm{~mL} \\ \mathrm{H}_{2} \mathrm{O} & 12,5 \mathrm{~mL} \\ \text { Solução E } & 60,0 \mu \mathrm{L} \\ \text { Temed } & 24,0 \mu \mathrm{L}\end{array}$

- Solução Estoque A

\begin{tabular}{|c|c|}
\hline Tris & $36,6 \mathrm{~g}$ \\
\hline $\mathrm{H}_{2} \mathrm{O}$ & $90,0 \mathrm{~mL}$ \\
\hline
\end{tabular}

- Solução Estoque B

$\begin{array}{ll}\text { Tris } & 5,0 \mathrm{~g} \\ \mathrm{H}_{2} \mathrm{O} & 90,0 \mathrm{~mL}\end{array}$

Acertar para $\mathrm{pH}$ 6,9 com $\mathrm{HCl}$

- Solução Estoque C

$\begin{array}{cl}\text { Acrilamida } & 28,0 \mathrm{~g} \\ \text { Bis-acrilamida } & 0,73 \mathrm{~mL} \\ \mathrm{H}_{2} \mathrm{O} & 100,0 \mathrm{~mL}\end{array}$

- Solução Estoque D

Acrilamida

Bis-acrilamida

$\mathrm{H}_{2} \mathrm{O}$

- Solução Estoque E

Persulfato de amônio

$\mathrm{H}_{2} \mathrm{O}$
$10,0 \mathrm{~g}$

$2,5 \mathrm{~mL}$

$100,0 \mathrm{~mL}$

$10,0 \mathrm{~g}$

$100,0 \mathrm{~mL}$ 
- Tampão de corrida e do reservatório

$\begin{array}{cc}\text { Tris } & 0,5 \mathrm{~g} / \mathrm{L} \\ \text { Glycine } & 2,8 \mathrm{~g} / \mathrm{L}\end{array}$

\subsubsection{Avaliação dos sistemas isoenzimáticos}

Foram testados no total 18 sistemas isoenzimáticos (Tabela 7). Os principais critérios para a escolha dos sistemas que seriam utilizados foram a resolução, presença de polimorfismo, repetibilidade e interpretabilidade.

Tabela 7. Enzimas testadas e utilizadas com seus respectivos códigos e siglas

\begin{tabular}{ccc}
\hline Enzima & Código* $^{*}$ & Sigla \\
\hline Aconitase hydratase & E.C.4.2.1.3 & ACO \\
Álcool desidrogenase & E.C.1.1.1.1 & ADH \\
Catalase & E.C.1.11.1.6 & CAT \\
Alfa Esterase & E.C.3.1.1.1 & a-EST \\
Fosfatase ácida & E.C.3.1.3.2 & ACP \\
Fosfoglucomutase & E.C.2.7.5.1 & PGM \\
Glucose-6-fosfato desidrogenase & E.C.1.1.1.49 & G6PDH \\
Fosfoglucose isomerase & E.C.5.3.1.9 & PGI \\
Glutamato desidrogenase & E.C.1.4.1.3 & GTDH \\
Glutamato oxaloacetato transaminase & E.C.2.6.1.1 & ATT \\
Isocitrato desidrogenase & E.C.1.1.1.42 & IDH \\
Leucina aminopeptidase & E.C.3.4.11.1 & LAP \\
Malato desidrogenase & E.C.1.1.1.37 & MDH \\
Manitol desidrogenase & E.C.1.1.1.67 & MADH \\
Peroxidase & E.C.1.11.1.7 & PRX \\
Sorbitol desidrogenase & E.C.1.1.1.14 & SDH \\
Superóxido dismutase & E.C.1.15.1.1 & SOD \\
Xiquimato desidrogenase & E.C.1.1.1.25 & SKDH
\end{tabular}

${ }^{*}$ Código E.C. da "Enzime Commission of the International Union of Biochemistry" obtido a partir de Alfenas et al. (1991). 


\subsubsection{Revelação das enzimas}

Após a migração das enzimas através dos géis de amido e poliacrilamida sob a ação de um campo elétrico, foi realizada a revelação histoquímica das enzimas. Estas ficam distribuídas no gel de acordo com seu peso molecular (decrescente) em direção ao pólo positivo. A detecção das enzimas ou bandas são obtidas através do reconhecimento dessa proteína pelo substrato específico colocado na solução reveladora.

Essas reações histoquímicas foram realizadas conforme Alfenas et al. (1991) modificadas e aperfeiçoadas no Laboratório de Ecologia Evolutiva e Genética Aplicada (LEEGA) do Departamento de Genética, USP/ESALQ.

No presente estudo os sistemas enzimáticos selecionados nos testes preliminares para análise foram: para o gel de amido apenas o sistema malato desidrogenase $(\mathrm{MDH})$ e para o gel de poliacrilamida selecionaram-se seis sistemas: fosfoglucomutase (PGM), glucose-6-fosfato desidrogenase $\left(\mathrm{G}_{6} \mathrm{PDH}\right)$, glucose-6-fosfato isomerase (GPI), superóxido dismutase (SOD), xiquimato desidrogenase (SKDH) e glutamato oxaloacetato transaminase (ATT) (Figura 13; Apêndice 1). Os demais sistemas foram eliminados das análises em razão da baixa atividade, evidenciada por bandas fracas no gel.
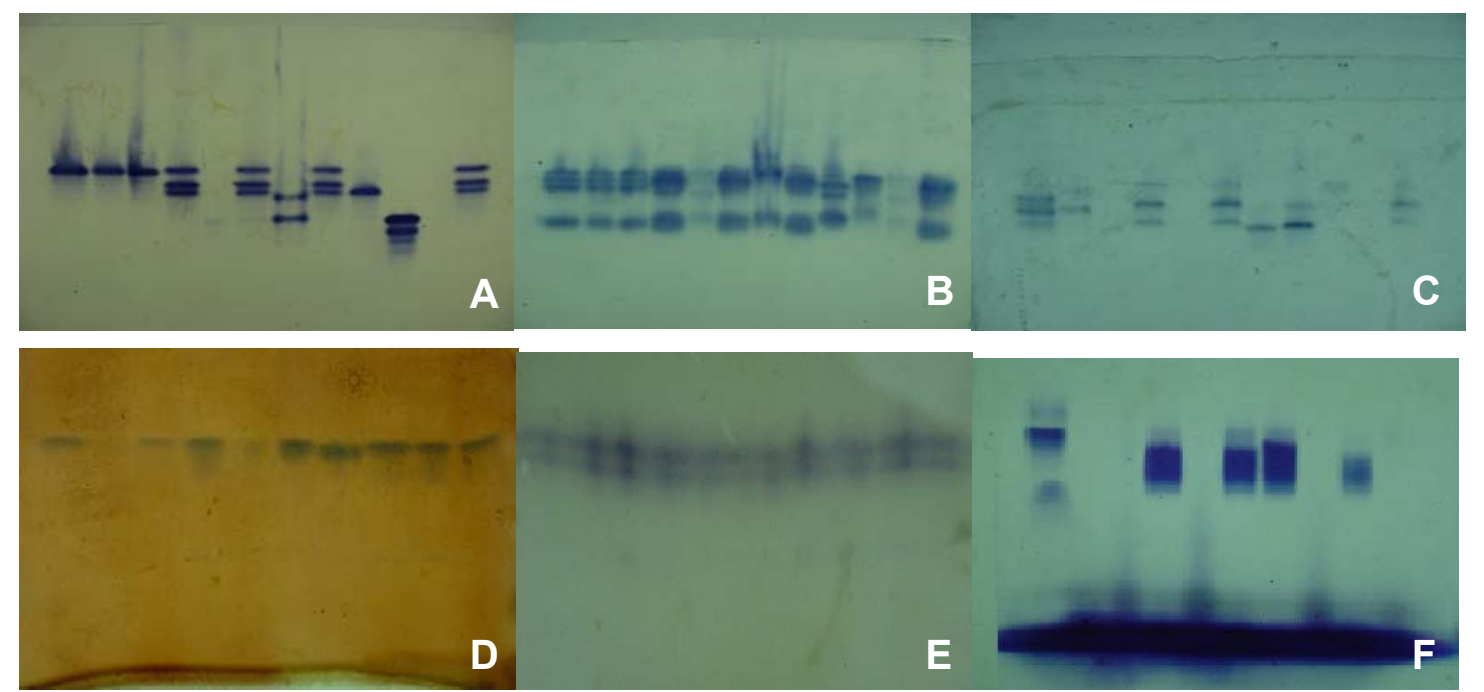

Figura 13 - Sistemas isoenzimáticos utilizados para as espécies de inhame: SKDH (A),

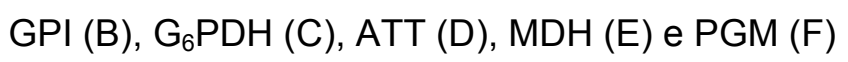




\subsubsection{Análise morfológica}

As avaliações morfológicas foram realizadas no campo experimental do Departamento de Genética da ESALQ/USP. Essa decisão foi tomada pelo fato de que em Piracicaba todos os acessos estariam nas mesmas condições bióticas e abióticas o que não seria possível nas roças dos agricultores tradicionais no Vale do Ribeira. Entretanto, foi necessário tomar alguns cuidados para viabilizar a avaliação morfológica como a escolha dos caracteres e estágio fenológico, pois o caráter morfológico possui classes fenotípicas, as quais servem de referência para classificar determinado indivíduo (Sambatti, 1998).

Os descritores utilizados na caracterização morfológica foram selecionados a partir de uma lista preconizada pelo IPGRI e International Institute of Tropical Agriculture (IITA), em Ibadan, Nigéria, descritos com suas respectivas escalas de notas em IPGRI/IITA (1997).

Nem todos os descritores preconizados para as espécies de Dioscorea spp. foram utilizados para avaliação morfológica das espécies de inhame cultivadas pelos agricultores tradicionais do Vale do Ribeira, pois não foram encontrados nas espécies brasileiras, já que esses descritores foram preconizados para as espécies africanas. Como exemplo cita-se o descarte do descritor intensidade de pilosidade do caule não encontrado para as variedades brasileiras.

Para a caracterização das 25 etnovariedades de D. trifida foram avaliados 24 descritores morfológicos, sendo nove associados a características de folha, seis para 0 caule, oito para tubérculos e um para o florescimento (Tabelas 8, 9 e 10).

As avaliações morfológicas foram realizadas em duas etapas, sendo a primeira aos seis meses após o transplantio dos acessos no campo, pois nesta época havia disponibilidade suficiente de tecidos (folhas jovens, adultas e ramos) e a segunda ocorreu durante a colheita quando os tubérculos foram avaliados, pois nesta fase os tubérculos estão formados. 
Tabela 8. Descritores utilizados para avaliação morfológica do caule do inhame (Dioscorea spp.). Piracicaba - SP, 2005

\begin{tabular}{|c|c|}
\hline Características & Classes (códigos) \\
\hline Cor do caule & $\begin{array}{l}\text { 1. Verde } \\
\text { 2. Verde com faixas roxas } \\
\text { 3. Verde com faixas marrons } \\
\text { 4. Roxo }\end{array}$ \\
\hline Asas & $\begin{array}{l}\text { 1. Presente } \\
\text { 2. Ausente }\end{array}$ \\
\hline Espinhos & $\begin{array}{l}\text { 1. Presente } \\
\text { 2. Ausente }\end{array}$ \\
\hline Direção de crescimento & $\begin{array}{l}\text { 1. Horário } \\
\text { 2. Anti-horário }\end{array}$ \\
\hline Diâmetro do caule ( $15 \mathrm{~cm}$ da base da planta) & $\begin{array}{l}\text { 1. }<0,4 \mathrm{~cm} \\
\text { 2. } 0,4-0,6 \mathrm{~cm} \\
\text { 3. }>0,6 \mathrm{~cm}\end{array}$ \\
\hline Formato do caule (corte transversal) & $\begin{array}{l}\text { 1. Poligonal } \\
\text { 2. Redondo }\end{array}$ \\
\hline
\end{tabular}


Tabela 9. Descritores utilizados para avaliação morfológica das folhas e florescimento do inhame (Dioscorea spp.). Piracicaba - SP, 2005

\begin{tabular}{|c|c|}
\hline Características & Classes (códigos) \\
\hline Posição das folhas & $\begin{array}{l}\text { 1. Alternada } \\
\text { 2. Oposta }\end{array}$ \\
\hline Forma das folhas & $\begin{array}{l}\text { 1. Cordata } \\
\text { 2. Sagitata }\end{array}$ \\
\hline Número de lóbulos da folha & $\begin{array}{l}\text { 1. Um } \\
\text { 2. Três }\end{array}$ \\
\hline Comprimento do pecíolo & $\begin{array}{l}\text { 1. }<5 \mathrm{~cm} \\
\text { 2. } 5-10 \mathrm{~cm} \\
\text { 3. }>10 \mathrm{~cm}\end{array}$ \\
\hline Cor do pecíolo & $\begin{array}{l}\text { 1. Verde } \\
\text { 2. Verde com marrom } \\
\text { 3. Roxo }\end{array}$ \\
\hline $\begin{array}{l}\text { L3 -Distância entre a inserção do pecíolo na } \\
\text { folha à extremidade superior da folha } \\
\text { (folhas adultas) }\end{array}$ & $\begin{array}{l}\text { 1. }<2 \mathrm{~cm} \\
\text { 2. } 2-4 \mathrm{~cm} \\
\text { 3. }>2 \mathrm{~cm}\end{array}$ \\
\hline $\begin{array}{l}\text { L2 - Distância entre a inserção do pecíolo } \\
\text { na folha à extremidade inferior da folha } \\
\text { (folhas adultas) }\end{array}$ & $\begin{array}{l}\text { 1. }<10 \mathrm{~cm} \\
\text { 2. } 10-15 \mathrm{~cm} \\
\text { 3. }>15 \mathrm{~cm}\end{array}$ \\
\hline $\begin{array}{l}\text { W1 - Largura da folha na maior porção } \\
\text { (folhas adultas) }\end{array}$ & $\begin{array}{l}\text { 1. }<10 \mathrm{~cm} \\
\text { 2. } 10-15 \mathrm{~cm} \\
\text { 3. }>15 \mathrm{~cm}\end{array}$ \\
\hline $\begin{array}{l}\text { W2 - Largura entre os lóbulos } \\
\text { (folhas adultas) }\end{array}$ & $\begin{array}{l}\text { 1. }<6 \mathrm{~cm} \\
\text { 2. } 6-10 \mathrm{~cm} \\
\text { 3. }>10 \mathrm{~cm}\end{array}$ \\
\hline Florescimento & $\begin{array}{l}\text { 1. Presente } \\
\text { 2. Ausente }\end{array}$ \\
\hline
\end{tabular}

Segundo relato dos agricultores as espécies $D$. trifida, $D$. bulbifera e $D$. alata não florescem naturalmente nas condições ambientais do Vale do Ribeira. Porém, nas condições de Piracicaba ocorreu florescimento espontâneo para essas espécies. Desta forma, analisou-se o florescimento apenas como caráter qualitativo binário (presença ou ausência). 
Tabela 10. Descritores utilizados para avaliação morfológica dos tubérculos do inhame (Dioscorea spp.). Piracicaba - SP, 2005

\begin{tabular}{|c|c|}
\hline Características & Classes (códigos) \\
\hline Tubérculos subterrâneos & $\begin{array}{l}\text { 1. Presente } \\
\text { 2. Ausente }\end{array}$ \\
\hline Número de tubérculos & $\begin{array}{l}\text { 1. Um } \\
\text { 2. Alguns } \\
\text { 3. Muitos }\end{array}$ \\
\hline Forma do tubérculo & $\begin{array}{l}\text { 1. Alongado } \\
\text { 2. Irregular }\end{array}$ \\
\hline Posição de junção entre os tubérculos & $\begin{array}{l}\text { 1. Todo } \\
\text { 2. Superior }\end{array}$ \\
\hline Comprimento do tubérculo & $\begin{array}{l}\text { 1. }<20 \mathrm{~cm} \\
\text { 2. } 20-40 \mathrm{~cm} \\
\text { 3. }>40 \mathrm{~cm}\end{array}$ \\
\hline Largura do tubérculo (eixo maior) & $\begin{array}{l}\text { 1. }<7 \mathrm{~cm} \\
\text { 2. } 7-12 \mathrm{~cm} \\
\text { 3. }>12 \mathrm{~cm}\end{array}$ \\
\hline Cor da casca & $\begin{array}{l}\text { 1. Marrom } \\
\text { 2. Amarela }\end{array}$ \\
\hline Cor da polpa & $\begin{array}{ll}\text { 1. } & \text { Branca } \\
\text { 2. Amarela } \\
\text { 3. Roxa } \\
\text { 4. Roxo com branco } \\
\text { 5. Branco com roxo }\end{array}$ \\
\hline
\end{tabular}

As avaliações permitiram construir uma tabela descritiva de todas as características morfológicas analisadas para as etnovariedades permitindo, desta forma, a análise estatística dos dados.

Optou-se pela transformação das observações obtidas dos caracteres em dados binários, pois $67 \%$ dos dados são qualitativos, muitos deles apresentando-se em classes e somente $33 \%$ são quantitativos. Os dados quantitativos foram obtidos a partir da média de 10 medidas para todos os caracteres, em cada planta do campo de conservação ex situ da ESALQ/USP. 


\subsubsection{Análise estatística}

Devido à natureza poliplóide das espécies de inhame, apresentando padrões de bandas muito complexos, não foi possível avaliar o material em termos de locos e alelos, para isoenzimas, não sendo possível, portanto, a avaliação de freqüências alélicas e genotípicas. Os materiais foram, portanto, genotipados como dados binários (presença $=1$ e ausência $=0$ ), gerando uma matriz binária. Os dados morfológicos também foram analisados por meio de notas, transformadas em dados binários de presença e ausência, gerando também uma matriz binária. Para as análises isoenzimáticas foram calculados o número de bandas por sistema, número total de bandas e porcentagem de bandas polimórficas.

Para ambos os dados foram calculados o índice de similaridade de Jaccard entre pares de indivíduos com base nas matrizes binárias dos dados isoenzimáticos e morfológicos. A estimação da variabilidade foi visualizada a partir dos índices médios de similaridade para variedades, roças e comunidades e dos dendrogramas baseados no método de agrupamento unweighted pair-group method with arithmetic averages (UPGMA), utilizando o programa NTSYSpc (Rohlf, 1992). O agrupamento das variedades, acessos e cultivares é importante para sumarizar as informações contidas nas matrizes (Dias, 1998).

O critério para a formação dos grupos foi adotar o limite mínimo de $50 \%$ de similaridade para os dados isoenzimáticos e $70 \%$ para os dados morfológicos entre as variedades, roças e comunidades para que fossem incluídas no mesmo grupo.

A avaliação da estabilidade dos agrupamentos dos dendrogramas foi baseada em estimativas de dissimilaridades genéticas através do procedimento de reamostragens com 1.000 bootstraps empregando o programa BOOD versão 2.0 e BOOD-P (Coelho, 2001, 2003). Neste programa, os valores superiores a $50 \%$ nos "nós", que unem os grupos, indicam que as distâncias genéticas entre as unidades biológicas de um mesmo grupo são estáveis.

Com o objetivo de simplificar a análise, foi realizada uma comparação apenas entre as roças e outra apenas para comunidades. As roças foram analisadas através da média da matriz de similaridade de Jaccard das etnovariedades dando origem a uma matriz, utilizada para estudar a variabilidade das roças a partir dos agrupamentos 
formados (Apêndices 2 e 3). Da mesma forma, as comunidades foram analisadas através da média da matriz de similaridade gerada para roças.

Contudo, a análise de agrupamento traz como conseqüência a perda de informações unitárias (acessos) restando apenas as informações sobre os grupos similares. Dessa forma, as informações foram complementadas com ferramentas como a análise de variância molecular (AMOVA) e a correlação de Pearson (r).

Desta forma, a matriz binária foi utilizada para a análise de variância molecular (AMOVA) que deve ser entendida como uma sumarização da diversidade molecular e morfológica, além de ajudar a entender a distribuição da diversidade, de acordo com os níveis hierárquicos.

A AMOVA foi utilizada somente para os materiais coletados nas roças dos agricultores tradicionais do Vale do Ribeira. Para tanto, utilizaram-se as distâncias ao quadrado, conforme descrito por Excoffier et al. (1992) com o auxílio do programa Arlequin (Schneider et al., 2004).

Com a finalidade de analisar os padrões de variação espacial, buscou-se correlacionar a diversidade genética (isoenzimática e morfológica) com a estrutura espacial, para tentar entender a dinâmica evolutiva da cultura dentro dos sistemas agrícolas tradicionais do Vale do Ribeira, pois as espécies sofrem pressão de forças evolutivas como a seleção, deriva genética, fluxo gênico, segregação, entre outros fatores que podem atuar conjunta ou isoladamente em diferentes intensidades determinando, desta forma, a existência ou não de um paralelismo entre as distâncias genéticas e geográficas. O coeficiente utilizado foi a correlação de Pearson ( $r$ ) através das matrizes de distâncias genéticas calculadas pelo índice de similaridade de Jaccard e as distâncias geográficas entre as espécies. A distância geográfica foi estimada a partir das coordenadas originais das roças e quintais utilizando o programa TrackMaker versão 12.3 (Ferreira Junior, 2004).

A correlação de Pearson ( $r$ ) também foi utilizada para verificar a associação entre a diversidade molecular (dados isoenzimáticos) e diversidade morfológica.

O nível de significância das correlações foi testado pelo método estatístico de Mantel (Z), utilizando 1.000 permutações aleatórias (Zucchi, 2002). Para a construção da matriz de similaridade e aplicação do teste de Mantel utilizou-se o programa NTSYSpc versão 2.0 (Rohlf, 1992). 


\subsection{Resultados e Discussão}

\subsubsection{Avaliação isoenzimática}

O sistema MDH apresentou o maior número de bandas (13) seguido pelo SOD com 12, GOT com 10, SKDH e PGI com 8, G ${ }_{6}$ PDH com 7 e PGM com 6, num total de 64 bandas para todos os sistemas. Observou-se $100 \%$ de bandas polimórficas, ou seja, nenhuma banda mostrou-se presente em todas as etnovariedades ao mesmo tempo. A combinação das diferentes bandas isoenzimáticas de todas as enzimas avaliadas nos dois tipos de géis (amido e poliacrilamida) possibilitou ainda a discriminação de 22 etnovariedades das 25 analisadas.

Esta técnica permitiu, portanto, a detecção de polimorfismo entre as etnovariedades de $D$. trifida coletadas nas roças dos agricultores tradicionais do Vale do Ribeira em todos os sistemas isoenzimáticos selecionados, permitindo desta forma, a discriminação da variabilidade genética entre as unidades evolutivas (roças e comunidades).

A análise de agrupamento das 25 etnovariedades de $D$. trifida revelou a formação de dez grupos ( $\mathrm{l}$ a $\mathrm{X}$ ), nos quais as etnovariedades foram distribuídas da seguinte forma: I (1,2); II (3, 4, 5, 6, 7, 8, 9, 10); III (15); IV (11, 12, 13); V (14); VI (16); VII (17); VIII (18), IX (19, 22, 23, 21, 20) e X (24, 25) (Figura 14; Tabela 2).

O coeficiente de similaridade de Jaccard entre os indivíduos 1 e 2 da roça 1 , indivíduos 5 e 6 da roça 2, ambas da comunidade de Icapara, e os indivíduos 7 e 8 da roça 3 da comunidade de Momuna no município de Iguape foram iguais a 1 . Portanto, em três roças observaram-se dois acessos que representam duplicatas, pois apresentaram o mesmo fenótipo isoenzimático dentro de cada roça, embora os agricultores os tenham identificado como materiais diferentes, apesar de apresentarem o mesmo nome comum (Tabela 2).

Pela análise de agrupamento das etnovariedades, também foi verificado a formação de dois grandes grupos, sendo que o primeiro grupo abriga as etnovariedades do município de Iguape (I, II, III, IV, V e VI) e o segundo as de Cananéia (VII, VIII, IX e X), observando-se assim a separação entre os materiais desses dois municípios. 


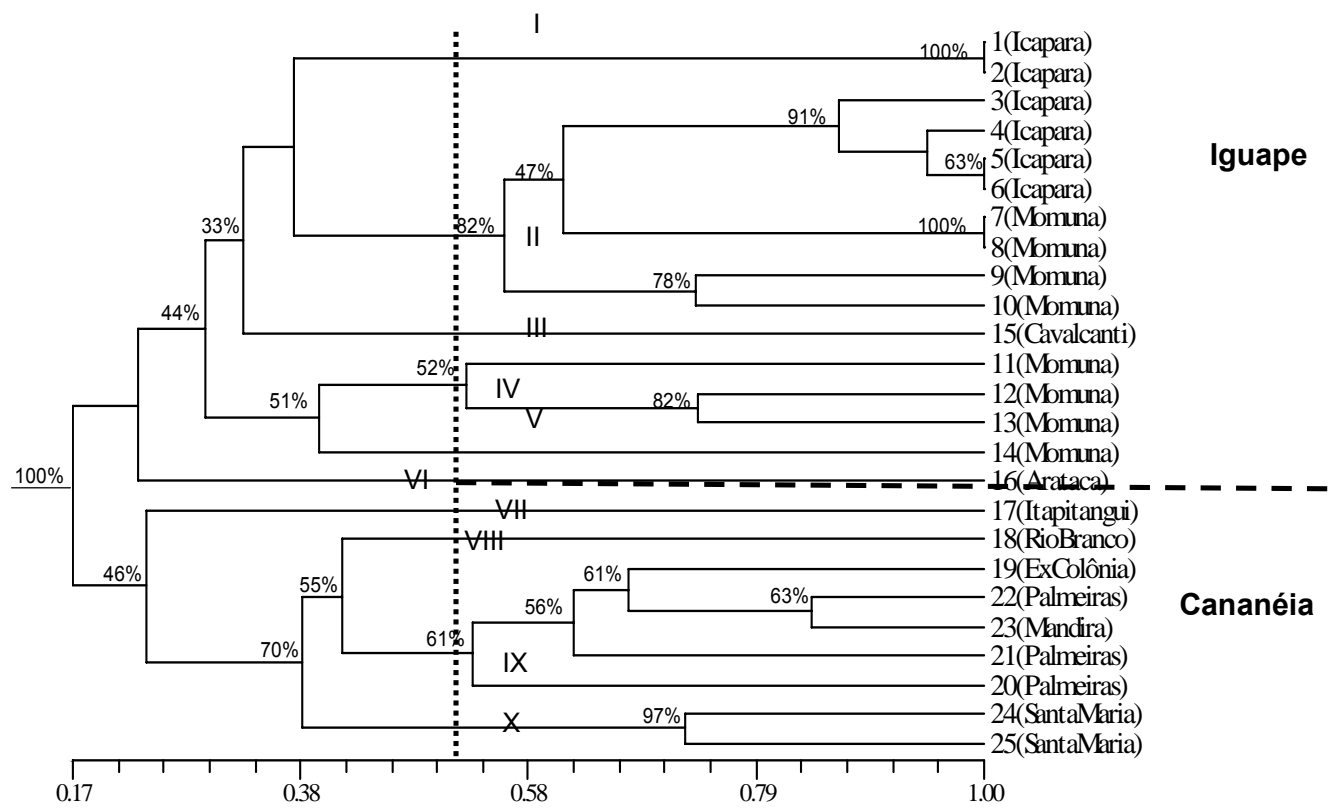

Figura 14 - Análise de agrupamento pelo método aglomerativo UPGMA relativo a 25 etnovariedades de $D$. trifida, com base em 64 bandas isoenzimáticas, de acordo com a similaridade do índice de Jaccard. Piracicaba-SP, 2005

Dos dendrogramas também é possível obter as amplitudes de similaridades para as etnovariedades. A amplitude de similaridade variou de 1,00 a 0,17 (Figura 14) indicando, desta forma, que as etnovariedades possuem uma variação de similaridade de $83 \%$, ou seja, existe grande diversidade entre os acessos de $D$. trifida coletados nas roças dos agricultores tradicionais do Vale do Ribeira.

Para a análise de agrupamento entre as comunidades (unidade evolutiva cultural) que cultivam $D$. trifida, observou-se a formação de nove grupos (I a IX), nos quais as comunidades foram distribuídas da seguinte forma: I (Icapara); II (Momuna); III (Cavalcanti); IV (Arataca); V (Itapitangui); VI (Rio Branco); VII (Ex-Colônia e Mandira); VIII (Palmeiras) e IX (Santa Maria) (Figura 15). Também se verifica a formação dos grandes grupos que separam as comunidades de Iguape (grupos I, II, III e IV) e Cananéia (grupos V, VI, VII, VIII e IX) através da análise como ocorreu para as análises de etnovariedades e das unidades biológicas (Figura 14 e Apêndice 2). 


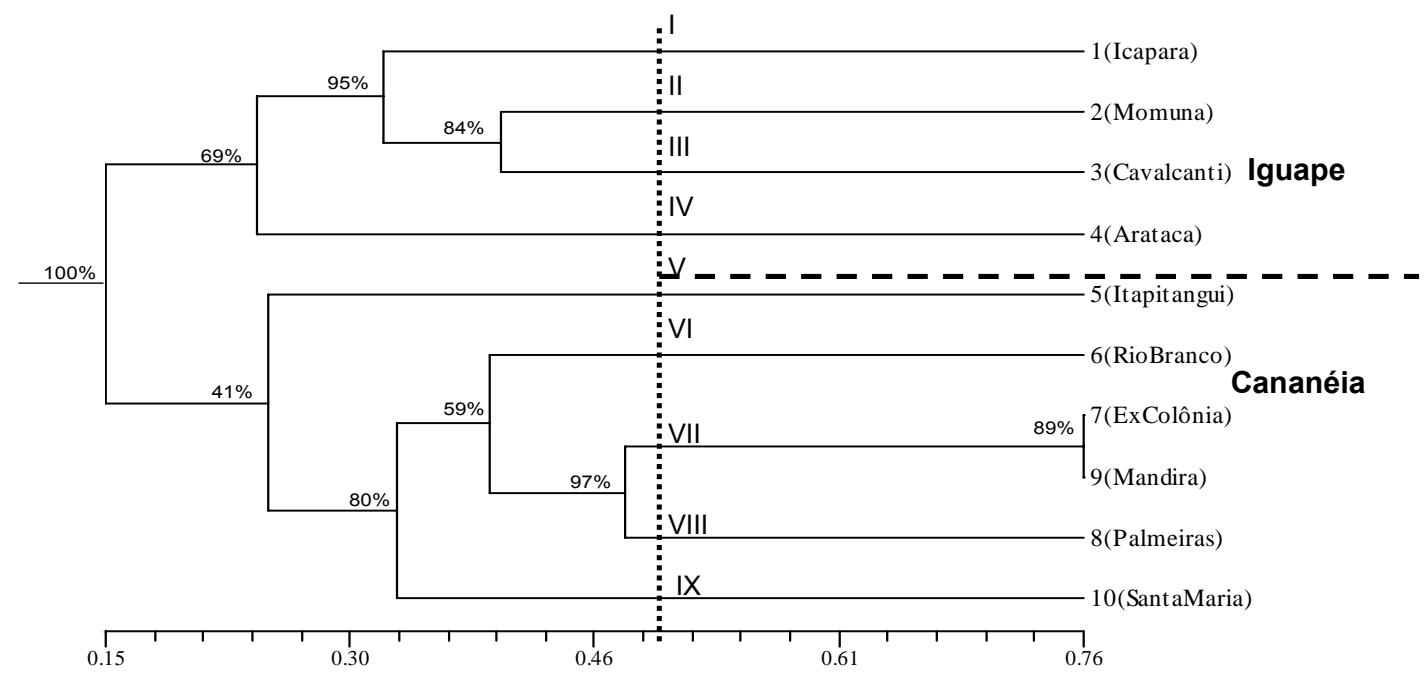

Figura 15 - Análise de agrupamento pelo método aglomerativo UPGMA relativo a 10 comunidades que cultivam D. trifida, com base em 64 bandas isoenzimáticas, de acordo com a similaridade do índice de Jaccard. Piracicaba-SP, 2005

Para as comunidades que cultivam $D$. trifida foram encontradas duas unidades culturais (Ex-Colônia e Mandira) que apresentam $76 \%$ de similaridade nos materiais cultivados.

As amplitudes de similaridade de Jaccard variaram em $61 \%$, ou seja, existe grande diversidade entre as unidades culturais. Este resultado é muito similar ao encontrado para as unidades biológicas (roças e quintais) mostrando, desta forma, que os resultados são muito congruentes.

Para $D$. trifida, este seria o primeiro relato na literatura sobre a estimação da diversidade isoenzimática observada entre etnovariedades cultivadas por agricultores tradicionais do Vale do Ribeira. Dansi et al. (2000) na República de Benin na África analisou 467 acessos do complexo D. cayenensis-rotundata e identificou 227 diferentes cultivares baseados nos padrões de bandas de sete sistemas isoenzimáticos: esterase (EST), AAT, $\mathrm{G}_{6} \mathrm{PDH}, \mathrm{IDH}, \mathrm{PGM}, \mathrm{GPI}$ e SKDH.

Os métodos hierárquicos aglomerativos são corriqueiramente utilizados na análise de dados biológicos. O método das médias das distâncias (UPGMA) é considerado por vários autores como um dos mais eficientes como conclui Dias (1998). 
Este método foi utilizado, com sucesso, para estudar a variabilidade genética através de polimorfismos em Sesbania sp. (Veasey, 1998), cagaiteira (Telles, 2001), cupuaçuzeiro (Alves, 2002), cagaiteira (Zucchi, 2002) e bromeliaceae (Cavallari, 2004).

O coeficiente de correlação de Pearson obtido foi nulo $(r=-0,09)$ e não significativo, sugerindo que não existe correlação entre esses dois parâmetros e que, provavelmente, a distribuição das etnovariedades está ligada a fatores antrópicos.

Alves (2002), trabalhando com populações de cupuaçuzeiro, obteve um resultado semelhante, ou seja, um coeficiente de correlação negativo $(r=-0,13)$ e não significativo também indicando que as distâncias genéticas não podem ser explicadas pelas distâncias geográficas. Estes resultados diferiram do obtido por Telles et al. (2001) e Zucchi (2002), onde a distribuição geográfica foi responsável pela divergência genética em cagaiteira, indicando que o modelo de isolamento por distância explicaria a divergência genética. Os resultados de Zucchi (2002) mostram uma relação positiva $(r=0,87)$ e significativa a $1 \%$ de probabilidade.

A provável razão da discordância do presente trabalho com os supra citados decorre do fato de que existem trocas de materiais que não estão estruturadas no espaço, ou seja, a ação humana estaria interferindo nos processos evolutivos da espécie de inhame (D. trifida).

Com base nos dados de 64 bandas polimórficas utilizando a análise de variância molecular (AMOVA) verificou-se que 59,21\% da variabilidade encontra-se entre roças dentro de comunidades e $24,75 \%$ entre as comunidades (Tabela 11 ).

Tabela 11. Resultados da análise de variância molecular (AMOVA) para etnovariedades de Dioscorea trifida. Piracicaba-SP, 2005

\begin{tabular}{cccc}
\hline Fonte de variação & GL & SQ & $\begin{array}{c}\text { Porcentagem da variação } \\
\text { total }\end{array}$ \\
\hline Entre comunidades & 9 & 160,31 & 24,75 \\
Entre roças dentro de comunidades & 7 & 73,95 & 59,21 \\
Dentro de roças dentro de & 8 & 14,16 & 16,04 \\
comunidades & & & \\
Total & 24 & 248,44 & \\
\hline
\end{tabular}


O conhecimento da distribuição da variabilidade genética entre e dentro das unidades evolutivas é essencial para sugerir que a grande divergência entre roças (unidade biológica) dentro de comunidades (unidade cultural) é devida a ação de fatores evolutivos como a deriva genética (perda de genótipos) e a seleção antrópica atuando sobre os caracteres de interesse.

Estudos similares realizados com etnovariedades de mandioca, também com marcadores isoenzimáticos, indicaram para esta cultura que a maior parte da variabilidade encontra-se dentro de roças, bem como dentro de regiões (Peroni, 1998; Sambatti et al., 2001; Faraldo, 1999), concordando com o sistema reprodutivo da espécie por alogamia (Silva et al., 2003). Sambatti et al. (2001) avaliaram etnovariedades de mandioca provenientes de quatro roças de agricultura tradicional do município de Ubatuba, SP, utilizando quatro sistemas enzimáticos, concluíram que a diversidade isoenzimática concentrava-se basicamente dentro das roças, sugerindo grande fluxo gênico entre os agricultores estudados.

No caso do inhame avaliado neste estudo, também considerado planta alógama, apresentando dioicia (Zoundjihekpon et al., 1997), como apenas uma etnovariedade era cultivada em grande parte das roças amostradas, não foi possível detectar a variabilidade dentro de roças, sendo que a maior parte desta concentrou-se entre roças dentro de comunidades e dentro de municípios. Esta grande diversidade entre roças pode ser explicada pelo interesse dos agricultores tradicionais em manterem materiais diferentes em suas comunidades, sendo que cada agricultor estaria mantendo etnovariedades diferentes das cultivadas pelos vizinhos, havendo possibilidade de trocas entre materiais. O surgimento de plantas variantes decorrentes de sementes, resultado de recombinação genética é improvável na região, uma vez que não nenhuma vez foi relatado pelos agricultores durante a coleta deste material, a ocorrência de florescimento ou frutificação em $D$. trifida. Resta, portanto, a possibilidade da ocorrência de mutação, que ocorre em baixa freqüência, e das demais forças evolutivas como deriva genética, seleção natural e a própria seleção humana praticada pelos agricultores. A manutenção da diversidade na agricultura de subsistência requer algum tipo de intervenção humana, o que em espécies autógamas ou propagadas vegetativamente, que é o caso do inhame, pode ser obtida pela seleção de tipos particulares para o próximo plantio por ocasião da colheita (Ladizinsky, 1998). Além disso, plantas de propagação vegetativa são, em geral, altamente 
heterozigóticas, preservando a diversidade alélica em nível do indivíduo (Frankel et al., 1995).

\subsubsection{Avaliação morfológica}

Uma extensa lista de descritores morfológicos pode ser empregada para a caracterização da diversidade das espécies de inhame. Onyilagha (1986) avaliou acessos de $\mathrm{D}$. rotundata utilizando 40 caracteres morfológicos como tamanho da folha, do tubérculo, cor do tubérculo, número de espiguetas florais por nó, e comprimento da espigueta. Rhodes \& Martin (1972) utilizaram 100 caracteres para estudar a variação em 30 cultivares de D. alata, concluindo que apenas 28 foram úteis para a classificação dos cultivares, pois os outros descritores foram pouco informativos ou redundantes.

No presente estudo os descritores morfológicos selecionados foram os mais representativos para as espécies cultivadas pelos agricultores tradicionais do Vale do Ribeira. Os demais descritores foram eliminados das análises em razão da baixa informação fornecida e pela redundância dos resultados. Esses descritores permitiram descriminar a variabilidade genética existente entre as etnovariedades e entre as unidades evolutivas (roças e comunidades) que cultivam a espécie $D$. trifida no Vale do Ribeira.

Segundo Cury (1993), os métodos hierárquicos de agrupamento caracterizamse pela determinação dos pares de unidades taxonômicas operacionais (OTU's) onde os mais similares formarão os primeiros grupos. Na etapa seguinte ocorrerá a substituição das OTU's por um novo elemento resultante da união dos anteriores onde ocorrerá o cálculo dos coeficientes de semelhança entre os novos elementos (novos agrupamentos). O final do processo ocorre quando as OTU's estiverem reunidas em um só grupo, com posterior emissão do fenograma. Portanto, no método UPGMA o coeficiente de similaridade é dado pela média aritmética das distâncias entre as OTU's dos diferentes agrupamentos. Desta forma, os materiais mais divergentes geneticamente são alocados em grupos distintos e, conseqüentemente, os indivíduos mais similares são componentes de um mesmo grupo.

A análise de agrupamento das 25 etnovariedades de $D$. trifida revelou a formação de três grandes grupos (A, B e C) e seis grupos ( $\mathrm{a}$ VI), nos quais as 
etnovariedades foram distribuídas da seguinte forma: I (1,2, 4, 5, 6); II (3); III (20, 21 , 22, 23, 25); IV $(17,18,19,24) ; \mathrm{V}(7,8,10,15)$ e VI $(9,16,11,13,14,12)$ (Figura 16).

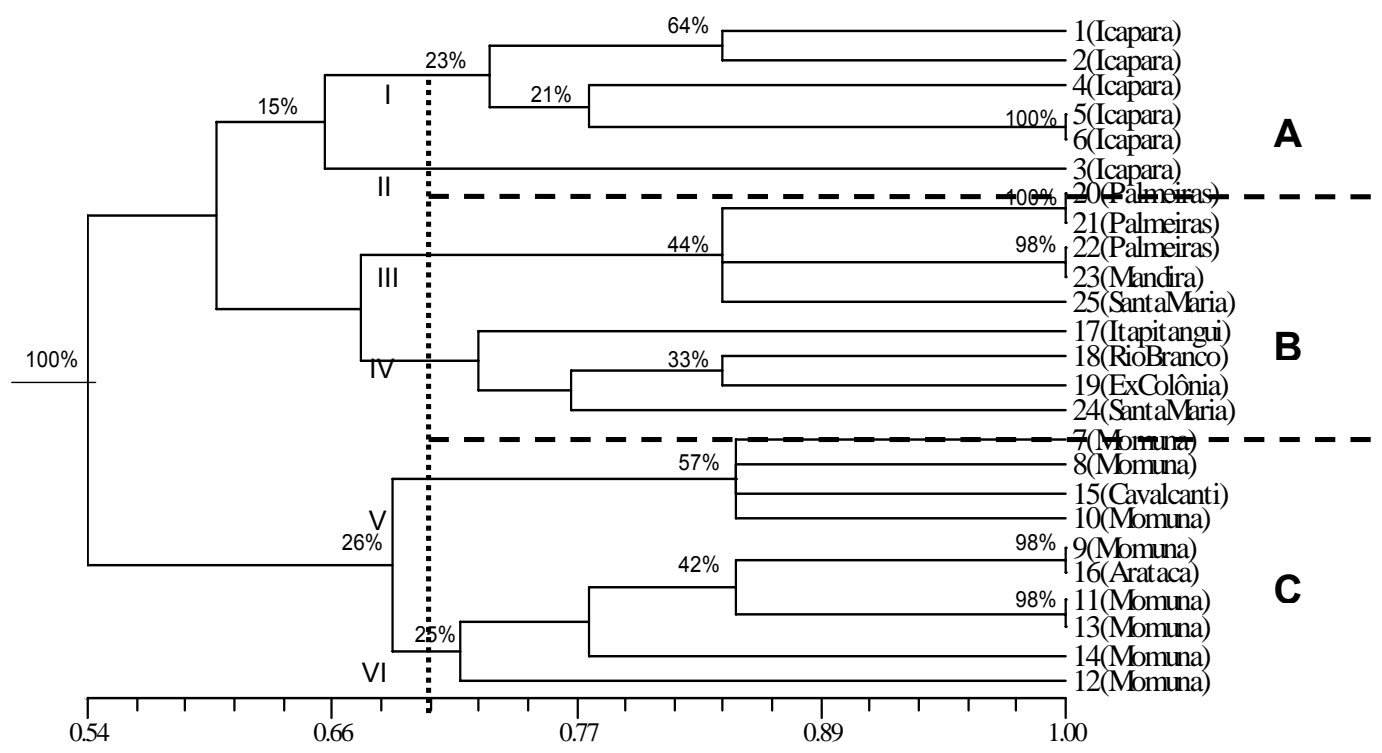

Figura 16 - Análise de agrupamento pelo método aglomerativo UPGMA relativo a 25 etnovariedades de $D$. trifida, com base em 24 caracteres morfológicos, de acordo com a similaridade do índice de Jaccard. Piracicaba-SP, 2005

O primeiro grande grupo (A) abriga as etnovariedades da comunidade de Icapara no município de Iguape (I, II) que cultivam variedades de inhame (D. trifida) com tubérculo alongado diferenciando-se das demais comunidades que cultivam a forma irregular; o segundo (B) compreende as etnovariedades de Cananéia (III e IV) de todas as comunidades, que cultivam variedades com caule verde com faixas marrons $\mathrm{e}$ pecíolo com cor verde e roxo; e o terceiro (C) envolvendo as comunidades de Momuna, Cavalcanti e Arataca ( $\mathrm{V}$ e $\mathrm{VI})$ no município de Iguape que não fazem parte da Área de Preservação Ambiental (APA) e que estão muito próximas (Figura 5) as roças dessas comunidades cultivam variedades com pecíolos com comprimento maior que $10 \mathrm{~cm}$ e distância entre a inserção do pecíolo na folha à extremidade superior da folha (L3) de 2 a $4 \mathrm{~cm}$, enquanto que os outros grupos ( $\mathrm{A}$ e $B$ ) apresentam medidas inferiores a $2 \mathrm{~cm}$. Desta forma, observou-se que as unidades culturais têm grande 
influência sobre os caracteres morfológicos, pois os agricultores cultivam materiais com aspectos morfológicos muito parecidos.

O coeficiente de similaridade de Jaccard entre os indivíduos 5 e 6 da roça 2, indivíduos 20 e 21 da roça 15, foram iguais a 1. Esses indivíduos apresentam, portanto, o mesmo fenótipo morfológico dentro de cada roça, embora os agricultores os tenham identificado como materiais diferentes, apesar de apresentarem o mesmo nome comum (Tabela 2).

Os acessos 22 e 23 (ambos denominados cará roxo) das roças 15 e 16 respectivamente, 9 (cará S. João) e 16 (cará Indaiá) das roças 4 e 11 e os indivíduos 11 e 13 (ambos cará branco) das roças 6 e 8 também apresentaram o mesmo fenótipo morfológico, embora sejam de unidades biológicas (roças) diferentes. Observou-se que mesmo sendo morfologicamente idênticos, os acessos 9 e 16 receberam nomes populares diferentes pelos agricultores, talvez pelo fato de estarem sendo cultivados em comunidades diferentes: Momuna e Arataca. No entanto, os acessos 22 e 34, com o mesmo nome comum, pertencem também a comunidades diferentes: Palmeiras e Mandira (Tabela 2). Isto estaria indicando que o mesmo nome comum pode estar sendo dado a etnovariedades diferentes, bem como etnovariedades idênticas morfologicamente podem estar recebendo nomes populares diferentes.

A identificação e classificação através dos nomes comuns pelos agricultores tradicionais para $D$. trifida, como cará São João, cará roxo, cará mirim-roxo, cará mirim, cará roxo Indaiá, cará São João roxo, cará São João branco, cará peludinho, cará pipa, cará prato e cará una, também pode encobrir diversos níveis de diversidade biológica, intra e interespecífica, entre e dentro das unidades evolutivas (biológica e cultural) do Vale do Ribeira. Os nomes comuns são freqüentemente associados aos aspectos morfológicos das plantas ou ao ciclo de vida de cada etnovariedade, pois os nomes "cará São João", "cará São João branco" e "cará São João roxo" são também atribuídos a etnovariedades de $D$. alata, mostrando que os agricultores não estão atentos às diferenças morfológicas entre as espécies, mas sim a cor do tubérculo (branco ou roxo) e a características culturais como o período de colheita, no mês de junho, durante as festas de São João.

Dos dendrogramas também pode-se obter as amplitudes de similaridades para as etnovariedades. A amplitude de similaridade variou de 1,00 a 0,54 indicando, desta 
forma, que as etnovariedades possuem uma variação de similaridade de $46 \%$, para os caracteres morfológicos.

Com o objetivo de simplificar a análise, foi realizada uma comparação apenas entre as roças (Apêndice 3) e outra apenas para comunidades (Figura 17).

Para a análise de agrupamento entre as comunidades que cultivam $D$. trifida, observa-se a formação de seis grupos ( $\mathrm{l}$ a $\mathrm{VI}$ ), nos quais as comunidades foram distribuídas da seguinte forma: I (Icapara); II (Momuna, Arataca, Palmeiras, Santa Maria e Rio Branco); III (Mandira); IV (Ex-Colônia); V (Itapitangui) e VI (Cavalcanti).

O critério para a formação dos grupos neste caso foi adotar o limite mínimo de $50 \%$ de similaridade entre as comunidades para que as mesmas fossem incluídas no mesmo grupo, pois a amplitude de similaridade de Jaccard variou no máximo em $65 \%$.

Observou-se a grande influência dos agricultores tradicionais na seleção e manutenção da diversidade genética do inhame ( $D$. trifida) no Vale do Ribeira, pois os caracteres morfológicos que separam os grupos A, B e C estão ligadas ao tipo de tubérculo, folhas e caule. Notou-se também o inter-relacionamento das unidades evolutivas (roças e comunidades) na formação dos grupos A, B e C, pois determinados caracteres morfológicos são encontrados em uma mesma unidade cultural (comunidade) apesar de que os agricultores manejam o nível biológico "roça".

Martins (2001) comenta que os agricultores tradicionais possuem grande sensibilidade para identificar as variedades manejadas por eles. Os caracteres usados na identificação das etnovariedades são a estrutura e coloração das folhas, a forma dos folíolos, a forma dos pecíolos, a coloração e o comprimento dos pecíolos, a forma e a coloração dos brotos e a coloração dos tubérculos. Contudo, a preferência cultural da comunidade pode ter forte influência na escolha de um material biológico. Dessa forma, pode-se verificar as principais preferências morfológicas das comunidades dos municípios de Iguape e Cananéia (A, B e C). 


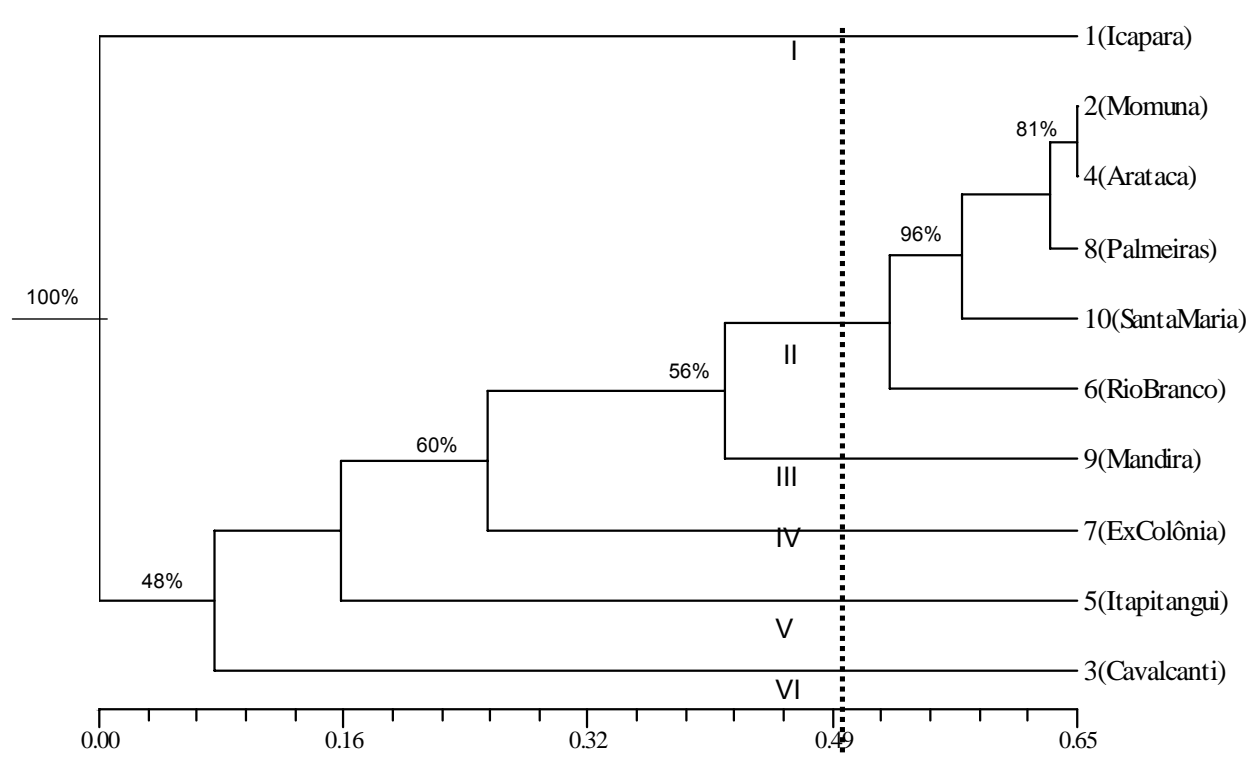

Figura 17 - Análise de agrupamento pelo método aglomerativo UPGMA relativo a 10 comunidades que cultivam $D$. trifida, com base em 24 caracteres morfológicos, de acordo com a similaridade do índice de Jaccard. Piracicaba-SP, 2005

A maior parte da diversidade fenotípica concentrada dentro das unidades evolutivas são relacionados com caracteres perceptivos. Para Sambatti (1998), a diversidade fenotípica para os agricultores tradicionais do litoral norte do Estado de São Paulo também está relacionada aos caracteres ligados à pigmentação, ou seja, são caracteres que o homem consegue selecionar. Outro ponto abordado é que o agricultor seleciona suas variedades para os diferentes ambientes de solo, clima e vegetação. Assim, pode-se verificar nas Figuras 16 e 17 que houve uma separação da diversidade morfológica quanto aos ambientes de produção agrícola, ou seja, as comunidades mais próximas agruparam-se.

Segundo Sambatti (1998), os agricultores tradicionais também estão sempre avaliando a performance de etnovariedades introduzidas, determinando o material que será cultivado no próximo ano. 
O coeficiente entre as correlações de distâncias morfológicas e as distâncias geográficas foi nulo $(r=0,01)$ e não significativo. Presume-se, desta forma, que a diversidade morfológica não estava estruturada no espaço, da mesma forma que o observado para isoenzimas.

Para o sistema agrícola tradicional do Vale do Ribeira a roça é a unidade geradora de variabilidade. Já a comunidade funciona como um sistema onde as trocas de materiais são constantes suprimindo as perdas dos agricultores. Este fato também é confirmado para a cultura da mandioca desta região e do litoral norte do Estado de São Paulo, pois os agricultores que perdem seu material biológico procuram com os vizinhos suprimindo desta forma, suas perdas (Peroni, 1998; Sambatti, 1998).

Com base nos dados de 24 caracteres morfológicos e 63 classes fenotípicas utilizando a análise de variância molecular (AMOVA), verificou-se que 39,0\% da variabilidade encontra-se dentro de roças dentro de comunidades e $37,12 \%$ entre as comunidades (Tabela 12).

Tabela 12. Resultados da análise de variância molecular (AMOVA) para os dados morfológicos de Dioscorea trifida. Piracicaba-SP, 2005

\begin{tabular}{cccc}
\hline Fonte de variação & GL & SQ & $\begin{array}{c}\text { Porcentagem da variação } \\
\text { total }\end{array}$ \\
\hline Entre comunidades & 9 & 87,69 & 37,12 \\
Entre roças dentro de comunidades & 7 & 30,58 & 23,88 \\
Dentro de roças dentro de & 8 & 19,17 & 39,00 \\
$\begin{array}{c}\text { comunidades } \\
\text { Total }\end{array}$ & 24 & 137,44 & \\
\hline
\end{tabular}

A diversidade morfológica está distribuída entre e dentro das unidades evolutivas (roças e comunidades), portanto, o fato das roças representarem grande parte da diversidade genética da região pode conduzir à afirmação de que a deriva genética é o fator evolutivo que terá maior pressão de seleção na variabilidade genética da cultura do inhame (D. trifida) no Vale do Ribeira, seguida pela seleção praticada pelos agricultores.

Para a cultura da mandioca no litoral norte do Estado de São Paulo a maior parte da diversidade genética está distribuída dentro das roças dos agricultores 
tradicionais, portanto a manutenção da dinâmica evolutiva está ligada a pressão de seleção humana, sendo que desta forma a conservação in situ é muito importante na região (Sambatti, 1998). Além da seleção perceptiva dos agricultores, outros fatores como a seleção natural e a deriva genética estão agindo sobre a variabilidade genética discriminada na forma de etnovariedades, como na variabilidade subestimada pelos agricultores (Peroni, 1998).

Em síntese, a amplificação da variabilidade existente na cultura do inhame ( $D$. trifida) está ligada essencialmente ao manejo empregado pelos agricultores tradicionais, através da introdução ou troca de etnovariedades dentro da comunidade e entre comunidades como descrito por Martins (2001) para a cultura da mandioca. Dessa forma, a agricultura tradicional tem um papel mais importante que mantenedor da diversidade genética (banco de reserva gênica), ela também gera e amplifica a variabilidade em um processo contínuo de acordo com suas necessidades culturais.

Quando essas populações tradicionais forem obrigadas a interromper ou mesmo diminuir suas atividades itinerantes que vão desde a falta de titulação legal das áreas de cultivo até as restrições à prática de agricultura (corte e queima) pela legislação ambiental, poderá ocorrer no futuro não só a perda de variabilidade, mas também dos processos evolutivos. Dessa forma, as políticas de conservação têm que levar em consideração o papel dos agricultores na conservação in situ de diversas espécies da Mata Atlântica.

\subsubsection{Correlação entre estimativas isoenzimáticas e morfológicas}

Para D. trifida, o coeficiente de correlação entre distâncias isoenzimáticas e morfológicas foi positivo $(r=0,21)$, mas não significativo ( $p=0,99)$, sugerindo que estatisticamente não existe correlação entre esses parâmetros. Detectaram-se cinco pares de acessos morfologicamente idênticos pela análise de agrupamento entre etnovariedades (Figura 16), e destes apenas um par (acessos 5 e 6) também foi idêntico para os padrões isoenzimáticos (Figura 14), ou seja, mesmo apresentando a mesma morfologia, os demais pares de acessos diferem em nível enzimático. Da mesma forma, os acessos 1 e 2 que se apresentaram idênticos nas análises isoenzimáticas diferiram morfologicamente, embora em pequena magnitude. Dessa 
forma, fica claro que o agricultor depara-se com algumas variações morfológicas que não refletem as diferenças isoenzimáticas, pois a espécie $D$. trifida sofre no Vale do Ribeira a ação de duas forças evolutivas como a deriva genética e a seleção humana para caracteres como a forma do tubérculo e a arquitetura da planta (caule e folha).

A ausência de correlação entre as distâncias moleculares e morfológicas é devido a fraca cobertura genômica conseguida com os marcadores isoenzimáticos.

Colombo (1997) encontrou um valor de $r=0,32$ e $p<0,001$ entre as matrizes de similaridade obtidas a partir de dados moleculares e botânicos resultantes de dados de RAPD em mandioca, indicando a existência de correlação entre os dois tipos de dados. Já Quiros et al. (1990), estudando o cultivo de batata "inglesa" (Solanum tuberosum) nos Andes peruanos conseguiram observar evidências da subestimação da variabilidade genética intra-roça em agricultura autóctone, pois os agricultores podem repetir nomes comuns para variedades genotipicamente diferentes. No litoral sul do Estado de São Paulo (Vale do Ribeira), para a cultura da mandioca, os agricultores tradicionais conseguem identificar a "família" de genótipos de acordo com as características morfológicas, mas não conseguem distinguir indivíduos geneticamente diferentes dentro das variedades que apresentam semelhança morfológica (Peroni, 1998).

Pode-se notar, no entanto, que existe certa congruência em ambos os dados genéticos, morfológicos e isoenzimáticos, ou seja, a formação de grupos separando os municípios de Iguape e Cananéia.

\subsection{Conclusões}

Os marcadores morfológicos e moleculares revelaram que os agricultores tradicionais mantêm na região do Vale do Ribeira grande diversidade genética para $D$. trifida. Porém, nas AMOVAS verificou-se divergência entre os marcadores isoenzimáticos e morfológicos quanto à distribuição da variabilidade, pois, o primeiro concentra a distribuição entre roças dentro de comunidades, já o segundo dentro de roças, ressaltando-se para os marcadores morfológicos, a importância da seleção humana para os caracteres visuais.

Pelo fato de não ter havido correlação entre a distância genética e geográfica recomenda-se para atividades futuras de coleta de germoplasma desta espécie 
manejada pelos agricultores tradicionais do Vale do Ribeira a não estruturação geográfica da mesma, pois existe grande interferência antropogênica na distribuição dessa variabilidade.

Verificou-se também que nomes comuns ("cará roxo", "cará una", "cará branco", “cará São João”, “cará São João roxo”, “cará peludinho”, "cará indaiá”, “cará pipa” entre outros), empregados pelos agricultores tradicionais podem, além de encobrir níveis de diversidade intraespecífica, gerar uma certa confusão, pois alguns desses nomes são também utilizados para outra espécie como $D$. alata. Isto se deve ao fato de que os nomes populares são as únicas unidades de classificação e identificação reconhecidas pelo agricultor.

Em suma, recomendam-se estudos mais detalhados para esta espécie, pois, ela tem seu centro de origem nas Américas. 


\section{DIVERSIDADE ISOENZIMÁTICA E MORFOLÓGICA DE Dioscorea bulbifera EM ROÇAS DE AGRICULTURA TRADICIONAL DO VALE DO RIBEIRA - SP}

\section{Resumo}

Na região sul do Estado de São Paulo encontra-se a agricultura autóctone coexistindo com corredores semi-intactos de Floresta Atlântica. Esses agricultores tradicionais têm se mostrado mantenedores e geradores de diversidade genética de plantas cultivadas como o inhame (Dioscorea spp). O presente estudo teve como objetivo avaliar a diversidade genética de 17 etnovariedades e 6 variedades comerciais de $D$. bulbifera, por meio de marcadores isoenzimáticos e morfológicos, verificando como esta se distribui nos diferentes níveis de organização, como roças e comunidades do Vale do Ribeira. Para as análises isoenzimáticas, foram utilizados géis de poliacrilamida (seis sistemas enzimáticos) e amido (um sistema) e para os marcadores morfológicos foram avaliados 24 caracteres. Devido à natureza poliplóide do inhame os materiais foram genotipados gerando dados binários. Os dados morfológicos também foram analisados por meio de notas transformados em uma matriz binária. Para ambos os dados foi calculado o índice de similaridade de Jaccard entre pares de indivíduos. A partir dos índices médios de similaridade de Jaccard para variedades, roças e comunidades foram feitos dendrogramas pelo critério de agrupamento UPGMA. Pelas análises de agrupamento houve a formação de três grandes grupos, sendo que o primeiro agrupou as etnovariedades do município de Iguape, o segundo os acessos do IAC (Instituto Agronômico de Campinas) e Peropava e o terceiro as etnovariedades de Cananéia e São João Del Rei para as análises isoenzimáticas. Outro parâmetro analisado foi a correlação entre as matrizes de distância genética e geográfica, verificando-se um valor positivo $(r=0,41)$, mas não significativo para isoenzimas, sugerindo que não existe correlação entre esses dois parâmetros. Foi também realizada a análise de variância molecular (AMOVA) onde 
pôde-se verificar que a maior parte da variabilidade isoenzimática encontrava-se entre roças dentro de comunidades (64,76\%). Para a análise morfológica, os agrupamentos indicaram a formação de dois grupos (Iguape e Cananéia), mostrando a grande influência das unidades culturais sobre os caracteres morfológicos. A correlação entre as distâncias morfológicas e geográficas também indicou que a diversidade não estava estruturada no espaço $(r=0,17)$. De acordo com a AMOVA, a maior parte da variabilidade morfológica encontrava-se dentro de roças dentro de comunidades $(44,27 \%)$. Correlacionando-se as estimativas isoenzimáticas e morfológicas chegou-se a uma correlação positiva $(r=0,19)$, mas não significativa estatisticamente. Os marcadores isoenzimáticos e morfológicos revelaram que, além da grande diversidade genética das etnovariedades de $D$. bulbifera, os agricultores tradicionais cultivam alguns materiais que se assemelham aos comerciais avaliados. 


\section{ISOENZYMATIC AND MORPHOLOGICAL DIVERSITY OF Dioscorea bulbifera IN SWIDDENS OF TRADITIONAL AGRICULTURE OF THE RIBEIRA RIVER VALLEY- SP}

\section{Summary}

In the south region of the State of São Paulo authoctone agriculture coexists with semi-intact corridors of the Atlantic Forest. These traditional agriculturists have been maintainers and generators of genetic diversity of cultivated plants such as yam (Dioscorea spp). The objective of this study was to evaluate, using isoenzyme and morphological markers, the genetic diversity of 17 ethnovarieties and six commercial varieties of $D$. bulbifera, verifying how this diversity is distributed in the different organization levels, such as swiddens and communities of the Ribeira River Valley. The isozyme analysis were conducted with polyacrylamide (six enzyme systems) and starch gels (one enzyme system) and morphological markers (24 characters). Due to the polyploid nature of yams the material was scored as binary data. The morphological data were also transformed into a binary matrix. Cluster analyses were conducted for ethnovarieties, swiddens and communities using the Jaccard similarity index among pairs of individuals and the UPGMA clustering method. Three great groups were observed in the cluster analyses of isozyme markers, the first classifying the ethnovarieties of Iguape municipality, the second the accessions from IAC (Instituto Agronômico) and Peropava, and the third the ethnovarieties of Cananéia and São João del Rei. Another parameter analyzed was the correlation between the genetic and geographic distances matrices for isozyme data, where a positive value was obtained $(r$ $=0.41$ ), but not significant, suggesting the non existence of correlation between these two parameters. The molecular analysis of variance (AMOVA) was also conducted, indicating that most of the isozymic variability was concentrated between swiddens within communities (64.76\%). The cluster analyses for the morphological data indicated the presence of two groups (Iguape and Cananéia), which showed the great influence of the cultural units on the morphological characters. The correlation between the geographic and the genetic distances also indicated that the morphological diversity was not structured in space $(r=0.17)$. According to the AMOVA, most of the morphological variability was concentrated within swiddens within communities $(44.27 \%)$. When correlating the isozymic and the morphological markers, a positive 
correlation ( $r=0.19$ ) was found, but statistically not significant. The isozymic and morphological markers revealed that, besides the high genetic diversity observed for $D$. bulbifera ethnovarieties, the traditional agriculturists also cultivate in their swiddens some varieties closely related to the commercial accessions evaluated. 


\subsection{Introdução}

O gênero Dioscorea é conhecido universalmente por suas propriedades alimentícias e farmacológicas. Este gênero é grande, aproximadamente 600 espécies, e possui representantes em várias partes do mundo, de modo que sua origem e distribuição são muito discutidas. No entanto, as espécies que possuem valor alimentício são de origem tropical. Pedralli (1988) cita que a espécie $D$. bulbifera é originária da Ásia, porém, Monteiro \& Peressim (2002) afirmam que a África seria o berço das espécies $D$. bulbifera L., $D$. cayenensis Lam. e $D$. rotundata Poir..

Os inhames africanos $(D$. bulbifera e $D$. rotundata) foram domesticados em áreas florestadas, possivelmente nas zonas de contato entre floresta/savana e, posteriormente, penetraram para o interior da floresta. Isto é evidenciado pela presença do tubérculo de produção anual. Durante a estação chuvosa, a parte vegetativa cresce em detrimento ao tubérculo, sendo que ao final da estação chuvosa o crescimento da planta é revertido para o tubérculo. As tribos africanas da floresta possuem um grande sentimento religioso reservado para com o inhame, porém os estudos sobre as origens e as crenças da agricultura africana são muito negligenciados pela falta de pesquisa sistemática (Harlan, 1992). Ainda hoje os inhames são utilizados por comunidades nativas que desenvolveram o conceito de proteção às plantas silvestres por meio de rituais (Pedralli, 1988).

No entanto, é sabido que estas espécies foram introduzidas durante a colonização do Brasil pelos portugueses e escravos africanos (Monteiro \& Peressim, 2002). No Brasil, a importância desses cultivos alcançam três aspectos: cultivos de subsistência, cultivos de importância étnica ou cultural e os cultivos de importância econômica (Cereda, 2002a).

Em algumas regiões do Brasil (Sudeste e áreas de influencia técnica) esta hortaliça é conhecida pelo nome popular de cará, enquanto em outras é denominado de inhame (Norte e Nordeste).

A espécie $D$. bulbifera produz tubérculos aéreos se diferenciando das demais que produzem tubérculos subterrâneos. São conhecidos vulgarmente como cará do ar na região Sudeste, cará moela no Vale do Ribeira - SP, ou como inhame de sapateiro na região Nordeste do Brasil. Esses tubérculos integram a dieta humana, pois são ricos em carboidratos, contendo ainda apreciáveis teores de tiamina (vitamina $B_{1}$ ), 
riboflavina (vitamina $B_{2}$ ), niacina (vitamina $B_{5}$ ), além de vitamina $A$ e ácido ascórbico (vitamina C) (Mascarenhas \& Resende, 2002).

Na região sul do Estado de São Paulo encontramos corredores semi-intactos de Mata Atlântica coexistindo com roças de agricultura tradicional. Os agricultores tradicionais dessa região praticam uma agricultura de subsistência baseada no intenso trabalho familiar e baixo consumo de energia e têm se mostrado como grandes mantenedores e geradores de diversidade genética de espécies de inhame, além de outras espécies domesticadas, semi-domesticadas e nativas. Além disso, possuem grande conhecimento a respeito desta diversidade manejada.

Estudos feitos nesta região para a cultura da mandioca (Manihot esculenta Crantz) através de dados morfológicos e isoenzimáticos, revelaram a importância dos agricultores tradicionais para o cultivo desta espécie e na manutenção da variabilidade estabelecendo-se, inclusive, um modelo de dinâmica evolutiva para esta cultura (Martins, 1994; Cury, 1993 e 1998; Faraldo,1994 e 1999; Peroni, 1998; Sambatti, 1998; Silva, 2000). Outras espécies de propagação vegetativa como o inhame e a batatadoce cultivados pelos agricultores tradicionais estão agora sendo estudadas seguindo o mesmo modelo evolutivo da mandioca.

Análises isoenzimáticas e morfológicas também têm sido utilizadas na África visando caracterizar a diversidade de acessos de inhame (Hamon \& Toure, 1990; Zoundjihekpon et al., 1994; Mignouna et al., 2002).

Neste trabalho, propôs-se estimar a diversidade genética das etnovariedades de $D$. bulbifera cultivadas pelos agricultores tradicionais do Vale do Ribeira por intermédio do polimorfismo isoenzimático e morfológico. Buscou-se também verificar de que forma esta diversidade se distribui nos diferentes níveis de organização como roças e comunidades, além de verificar a existência de correlação entre as distâncias geográficas e as distâncias genéticas (isoenzima e morfologia) e entre ambos os marcadores utilizados.

\subsection{Material e Métodos}

Coletou-se 17 etnovariedades de $D$. bulbifera junto às comunidades que praticam a agricultura tradicional nos municípios de Cananéia $\left(25^{\circ} 00^{\prime} \mathrm{S}\right.$ e $\left.47^{\circ} 55^{\prime} \mathrm{W}\right)$ e Iguape $\left(24^{\circ} 42^{\prime} S\right.$ e $47^{\circ} 33^{\prime} \mathrm{W}$ ) (Figura 5). Além disso, utilizaram-se cinco materiais 
provenientes da coleção do Instituto Agronômico de Campinas (IAC) localizado na cidade de Campinas ( $22^{\circ} 53^{\prime} \mathrm{S}$ e $47^{\circ} 04^{\prime} \mathrm{W}$ ) e um material comercial proveniente de um varejão do município de São João Del Rei $\left(21^{\circ} 08^{\prime}\right.$ ' e $\left.44^{\circ} 15^{\prime} \mathrm{W}\right)$ no Estado de Minas Gerais para comparar com a diversidade manejada pelos agricultores tradicionais do Vale do Ribeira (Tabela 3).

Coletou-se um tubérculo aéreo de cada roça, com exceção do agricultor $5 \mathrm{da}$ comunidade de Peropava que possuía uma roça comercial onde coletaram-se sete tubérculos de diferentes pontos. Desta forma, o número médio de etnovariedades coletadas por roça foi de 1,7. Esses materiais foram trazidos para o Departamento de Genética da Escola Superior de Agricultura "Luiz de Queiroz" da Universidade de São Paulo, em Piracicaba-SP ( $22^{\circ} 43^{\prime} S$ e $47^{\circ} 43^{\prime} \mathrm{W}$ ) e plantados em vasos e mantidos em casa-de-vegetação em uma primeira etapa de brotação e quarentena. Dois meses após, as mudas foram transplantadas para um campo experimental preparado com fileiras em camalhões, sem repetição. O espaçamento entre fileiras e entre plantas foi de $1,50 \mathrm{~m}$. Para a condução das plantas utilizaram-se varas de bambu de aproximadamente $1,80 \mathrm{~m}$, visando orientar o crescimento das plantas. Foi originado, desta forma, o banco de germoplasma de conservação ex situ de $D$. bulbifera do Laboratório de Ecologia Evolutiva e Genética Aplicada (LEEGA).

Esses acessos foram analisados por meio de marcadores isoenzimáticos (Soltis \& Soltis, 1990; Silva, 2000) e morfológicos, visando verificar como se distribui a diversidade genética nos diferentes níveis hierárquicos: dentro de roças e quintais (unidade básica evolutiva), entre roças e quintais dentro de comunidades (unidade cultural) e entre comunidades do Vale do Ribeira. Além disso, buscou-se comparar as etnovariedades com os acessos provenientes do IAC e comercial, visando verificar se os agricultores tradicionais cultivam materiais comerciais em suas roças.

Nesta pesquisa convencionou-se que as unidades básicas evolutivas (roça e quintal) serão analisadas apenas como "roça", pois em ambos os locais são as famílias que manejam os materiais biológicos. 


\subsubsection{Análise isoenzimática}

O protocolo para extração e visualização das formas moleculares de uma mesma enzima foi adaptado de Mignouna et al. (2002) e utilizado na avaliação genética com base nos padrões isoenzimáticos dos acessos estudados. As enzimas foram extraídas a partir de amostras de folhas jovens (recém expandidas) de plantas adultas (6-8 meses) conforme o item 4.2.1.1 (Figuras 12; 13). Foram utilizados ambos géis de amido e poliacrilamida.

Para o gel de poliacrilamida, foi utilizado nas canaletas do gel polimerizado, uma alíquota de $25 \mu \mathrm{L}$ do extrato bruto (sobrenadante) misturado com $250 \mu \mathrm{L}$ de solução de azul de bromofenol, o qual serviu como parâmetro para a avaliação da migração das proteínas no gel. No caso do gel de amido, o sobrenadante era absorvido por pedaços de papel de filtro. Estes papéis foram colocados verticalmente no gel (lado a lado). Nas extremidades foram colocados papéis embebidos na solução de azul de bromofenol, o qual também serviu como parâmetro para a avaliação da migração das proteínas no gel. O restante do sobrenadante foi descartado devido à rápida degradação das enzimas do inhame. Os géis tanto de amido como poliacrilamida foram preparados de acordo com os itens 4.2.1.2 e 4.2.1.3.

Testou-se 18 sistemas isoenzimáticos (Tabela 7), sendo que os principais critérios para a escolha dos sistemas que seriam utilizados foram a resolução, presença de polimorfismo, repetibilidade e interpretabilidade.

Após a migração das enzimas através dos géis de amido e poliacrilamida sob a ação de um campo elétrico, foi realizada a revelação histoquímica das enzimas. Essas reações histoquímicas foram baseadas em Alfenas et al. (1991) com algumas adaptações.

Para a diversidade isoenzimática da espécie $D$. bulbifera foram selecionados os seguintes sistemas enzimáticos: gel de amido apenas o sistema MDH e para o gel de poliacrilamida os sistemas PGM, G 6 PDH, GPI, SOD, SKDH e ATT (Apêndice 1). Os demais sistemas foram eliminados das análises em razão da baixa atividade, evidenciada por bandas fracas no gel. 


\subsubsection{Análise morfológica}

As avaliações morfológicas foram realizadas no campo experimental do Departamento de Genética da ESALQ/USP, visando manter as mesmas condições bióticas e abióticas para os acessos o que não seria possível nas roças dos agricultores tradicionais no Vale do Ribeira.

Utilizou-se na caracterização morfológica os descritores preconizados pelo International Plant Genetic Resources Institute (IPGRI) e International Institute of Tropical Agriculture (IITA), em Ibadan, Nigéria, descritos com suas respectivas escalas de notas em IPGRI/IITA (1997).

Nem todos os descritores preconizados para as espécies de Dioscorea spp. foram utilizados para a avaliação morfológica das etnovariedades de $D$. bulbifera cultivadas pelos agricultores tradicionais do Vale do Ribeira, pois para alguns descritores não se observou variação entre os acessos. Como exemplo, cita-se o descarte do descritor intensidade de pilosidade do caule, não encontrado para as variedades brasileiras, o mesmo ocorrendo com a cor das folhas que o IPGRI/IITA cita como amarelo, verde pálido, verde escuro, verde arroxeado, roxo e outros e para $D$. bulbifera encontrou-se apenas a cor verde.

Foram, portanto, avaliados 24 descritores morfológicos, sendo nove associados a caracteres de folha, seis para o caule, sete para tubérculos e um para o florescimento (Tabelas 8, 9 e 10).

As avaliações morfológicas foram realizadas em duas etapas, sendo a primeira aos seis meses após o transplantio dos acessos no campo, pois nesta época havia disponibilidade suficiente de tecidos (folhas jovens, adultas e ramos) e a segunda ocorreu durante a colheita quando os tubérculos foram avaliados, pois nesta fase os tubérculos estão formados.

As observações foram baseadas na média fenotípica de 10 medições dos descritores quantitativos para folhas, caules e tubérculos de cada planta individual. No total foram avaliados nove descritores quantitativos e 15 qualitativos, atribuindo-se notas conforme o caráter. 


\subsubsection{Análise estatística}

Os padrões de bandas da espécie $D$. bulbifera apresentaram-se muito complexos, devido à natureza poliplóide das espécies, não sendo possível a avaliação do material em termos de locos e alelos ou por freqüências alélicas e genotípicas. Os materiais foram, portanto, genotipados como dados binários (presença $=1$ e ausência $=0$ ), gerando uma matriz binária. Os dados morfológicos também foram analisados por meio de notas, transformados em dados binários, gerando também uma matriz binária. Para as análises isoenzimáticas foram calculados o número de bandas por sistema, número total de bandas e porcentagem de bandas polimórficas.

Para ambos os dados foram calculados o índice de similaridade de Jaccard entre pares de indivíduos com base nas matrizes binárias dos dados isoenzimáticos e morfológicos. A estimação da variabilidade foi visualizada a partir dos índices médios de similaridade para variedades, roças e comunidades e dos dendrogramas baseados no método de agrupamento UPGMA, utilizando o programa NTSYSpc (Rohlf, 1992).

O critério para a formação dos grupos foi adotar o limite mínimo de $50 \%$ de similaridade para os dados isoenzimáticos e $70 \%$ para os dados morfológicos entre as variedades, roças e comunidades para que fossem incluídas no mesmo grupo.

A avaliação da estabilidade dos agrupamentos dos dendrogramas foi baseada em estimativas de dissimilaridades genéticas através do procedimento de reamostragens com 1.000 bootstraps empregando o programa BOOD versão 2.0 e BOOD-P (Coelho, 2001, 2003). Neste programa os valores superiores a $50 \%$ nos "nós", que unem os grupos, indicam que as distâncias genéticas entre as unidades biológicas de um mesmo grupo são estáveis.

Com o objetivo de simplificar a análise, foi realizada uma comparação apenas entre as roças e outra apenas para comunidades. As roças foram analisadas através da média da matriz de similaridade de Jaccard das etnovariedades dando origem a uma matriz, utilizada para estudar a variabilidade das roças a partir dos agrupamentos formados (Apêndices 4 e 5). Da mesma forma, as comunidades foram analisadas através da média da matriz de similaridade gerada para roças.

Contudo, a análise de agrupamento traz como conseqüência a perda de informações unitárias (acessos) restando apenas as informações sobre os grupos 
similares. Dessa forma, as informações foram complementadas com ferramentas como a análise de variância molecular (AMOVA) e a correlação de Pearson (r).

Desta forma, a matriz binária foi utilizada para a análise de variância molecular (AMOVA) que deve ser entendida como uma sumarização da diversidade molecular e morfológica, além de ajudar entender a distribuição da diversidade, de acordo com os níveis hierárquicos.

A AMOVA foi utilizada somente para os materiais coletados nas roças dos agricultores tradicionais do Vale do Ribeira. Para tanto, utilizaram-se as distâncias ao quadrado, conforme descrito por Excoffier et al. (1992) com o auxílio do programa Arlequin (Schneider et al., 2004).

Com a finalidade de analisar os padrões de variação espacial, buscou-se correlacionar a diversidade genética (isoenzimática e morfológica) com a estrutura espacial, para tentar entender a dinâmica evolutiva da cultura dentro dos sistemas agrícolas tradicionais do Vale do Ribeira, pois as espécies sofrem pressão de forças evolutivas como a seleção, deriva genética, fluxo gênico, segregação, entre outros fatores que podem atuar conjunta ou isoladamente em diferentes intensidades determinando, desta forma, a existência ou não de um paralelismo entre as distâncias genéticas e geográficas. O coeficiente utilizado foi a correlação de Pearson $(r)$ através das matrizes de distâncias genéticas calculadas pelo índice de similaridade de Jaccard e as distâncias geográficas entre as espécies. A distância geográfica foi estimada a partir das coordenadas originais das roças e quintais utilizando o programa TrackMaker versão 12.3 (Ferreira Junior, 2004).

A correlação de Pearson ( $r$ ) também foi utilizada para verificar a associação entre a diversidade molecular (dados isoenzimáticos) e diversidade morfológica.

O nível de significância das correlações foi testada pelo método estatístico de Mantel (Z), utilizando 1.000 permutações aleatórias (Zucchi, 2002). Para a construção da matriz de similaridade e aplicação do teste de Mantel utilizou-se o programa NTSYSpc versão 2.0 (Rohlf, 1992). 


\subsection{Resultados e Discussão}

\subsubsection{Avaliação isoenzimática}

Este é o primeiro relato sobre a estimação da diversidade isoenzimática observada entre etnovariedades de $D$. bulbifera cultivadas por agricultores tradicionais do Vale do Ribeira.

Diversos trabalhos como Hamon \& Toure (1990), Dansi et al. (2000), Mignouna et al. (2002), entre outros, relatam a utilização de sistemas isoenzimáticos para análise de acessos do complexo $D$. cayenensis-rotundata, porém, na literatura não encontra-se o emprego desta tecnologia para analisar a espécie $D$. bulbifera. Contudo, a combinação das diferentes bandas isoenzimáticas de todas as enzimas avaliadas nos dois tipos de géis (amido e poliacrilamida) possibilitou a discriminação de 10 etnovariedades das 17 analisadas, além dos acessos do IAC e de São João Del Rei.

O sistema MDH apresentou o maior número de bandas (14) seguido pelo GOT com 13, SOD com 10, PGM, SKDH e PGI com 8 e G ${ }_{6}$ PDH com 6, num total de 67 bandas para todos os sistemas. Observou-se $100 \%$ de bandas polimórficas, ou seja, nenhuma banda mostrou-se presente em todas as etnovariedades e materiais comerciais ao mesmo tempo.

A análise de agrupamento revelou a formação de sete grupos (I a VII), nos quais as etnovariedades foram distribuídas da seguinte forma: I (1); II (2); III (3 e 4); IV $(5,6,7,8,9,10,11,12,13,14,15,16$ e 17); V (21); VI $(18,19,20$ e 22) e VII (23) (Figura 18).

Pela análise de agrupamento para as etnovariedades e demais acessos, também foi verificado a formação de três grandes grupos que merecem comentários $(A, B$ e $C)$.

O grupo A é formado por quatro etnovariedades cultivadas pelos agricultores tradicionais do município de Iguape das comunidades de Momuna e Cavalcanti, que são próximas. 


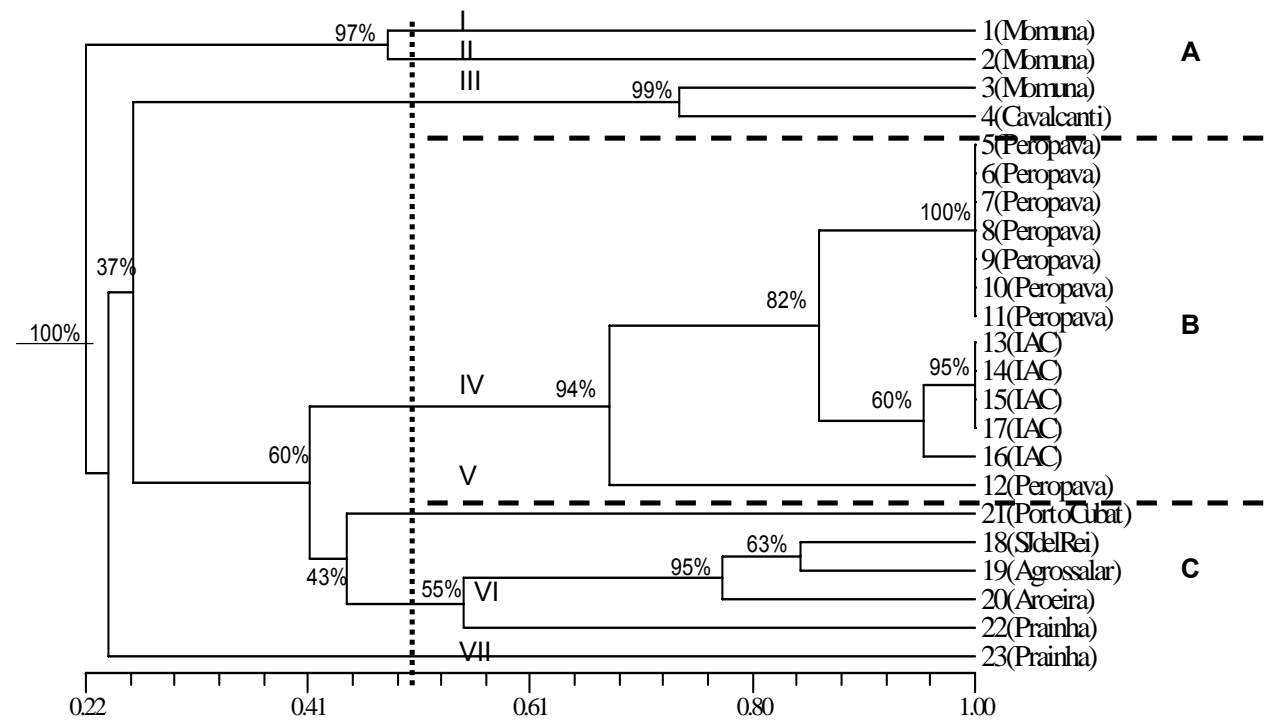

Figura 18 - Análise de agrupamento pelo método aglomerativo UPGMA relativo a 17 etnovariedades e seis acessos de $D$. bulbifera, com base em 67 bandas isoenzimáticas, de acordo com a similaridade do índice de Jaccard. Piracicaba-SP, 2005

O grupo B é formado por acessos provenientes de roças comerciais da comunidade de Peropava e do IAC. Os agricultores desta comunidade relataram que seus materiais eram provenientes das Centrais de Abastecimento de São Paulo S/A (CEASA); neste caso é possível que sejam materiais comerciais de outras regiões do Brasil. Dentro deste grande grupo (IV) o coeficiente de similaridade de Jaccard entre os indivíduos 5, 6, 7, 8, 9, 10 e 11 da roça 5 da comunidade de Peropava no município de Iguape, grupo IV, e os indivíduos 13, 14, 15 e 17 do IAC foram iguais a 1. Verificou-se desta forma, que na roça 5 da comunidade de Peropava o agricultor cultivava materiais geneticamente idênticos (clones), os quais eram geneticamente próximos aos acessos obtidos junto ao IAC (Tabela 3). Quanto aos materiais cedidos pelo IAC para fins de comparação verificou-se que houve um erro na separação dos materiais, pois o acesso 17 que foi caracterizado com o nome comum de Áspero normal, é um híbrido, pois apresentou o mesmo fenótipo que os acessos 13, 14 e 15. Esta técnica permitiu, 
portanto, observar a existência de clones, possibilitando, desta forma, a exclusão de duplicatas no banco de germoplasma.

Já o grupo $\mathrm{C}$ é constituído pelas etnovariedades cultivadas pelos agricultores tradicionais do município de Cananéia nas comunidades de Porto Cubatão, Agrossolar, Aroeira e Prainha. Além disso, verificou-se a presença do acesso de São João Del Rei, isto é possível porque esta espécie foi introduzida no Brasil nas diferentes regiões. Neste grupo nota-se também a presença de uma etnovariedade de $D$. bulbifera utilizada somente para fins medicinais, como o controle de diabetes. Esta etnovariedade (23) apresentou similaridade de diversidade isoenzimática de apenas $25 \%$ quando comparada com os outros materiais, ou seja, mostrou-se distante geneticamente das demais.

A amplitude de similaridade variou de 1,00 a 0,22 (Figura 18) indicando, desta forma, que as etnovariedades possuem uma variação de similaridade de $78 \%$. Pode-se afirmar, portanto, que existe grande diversidade entre os acessos de $D$. bulbifera coletados nas roças e quintais dos agricultores tradicionais dos municípios de lguape e Cananéia no Vale do Ribeira.

Para a análise de agrupamento entre as comunidades (unidade evolutiva cultural) e dois locais fora do Vale do Ribeira que cultivam D. bulbifera, observou-se a formação de seis grupos ( a VI) que foram distribuídos da seguinte forma: I (Momuna); II (Cavalcanti); III (Peropava e IAC); IV (Agrossolar, Aroeira e São João Del Rei/MG); V (Porto Cubatão) e VI (Prainha) (Figura 19).

O que mais chama a atenção na formação dos grupos é a presença constante dos materiais de Peropava com os acessos do IAC. Outro fato verificado foi a similaridade de $85 \%$ entre os materiais de Agrossolar e São João Del Rei, que continuam similares mesmo com a grande distância geográfica entre os locais. Não se conhece a procedência exata da variedade adquirida no varejão de São João Del Rei, mas imagina-se que seja proveniente da própria região.

A amplitude de similaridade de Jaccard variou para esta análise de agrupamento em $40 \%$ existindo, desta forma, grande diversidade entre as unidades culturais do Vale do Ribeira que cultivam $D$. bulbifera. 


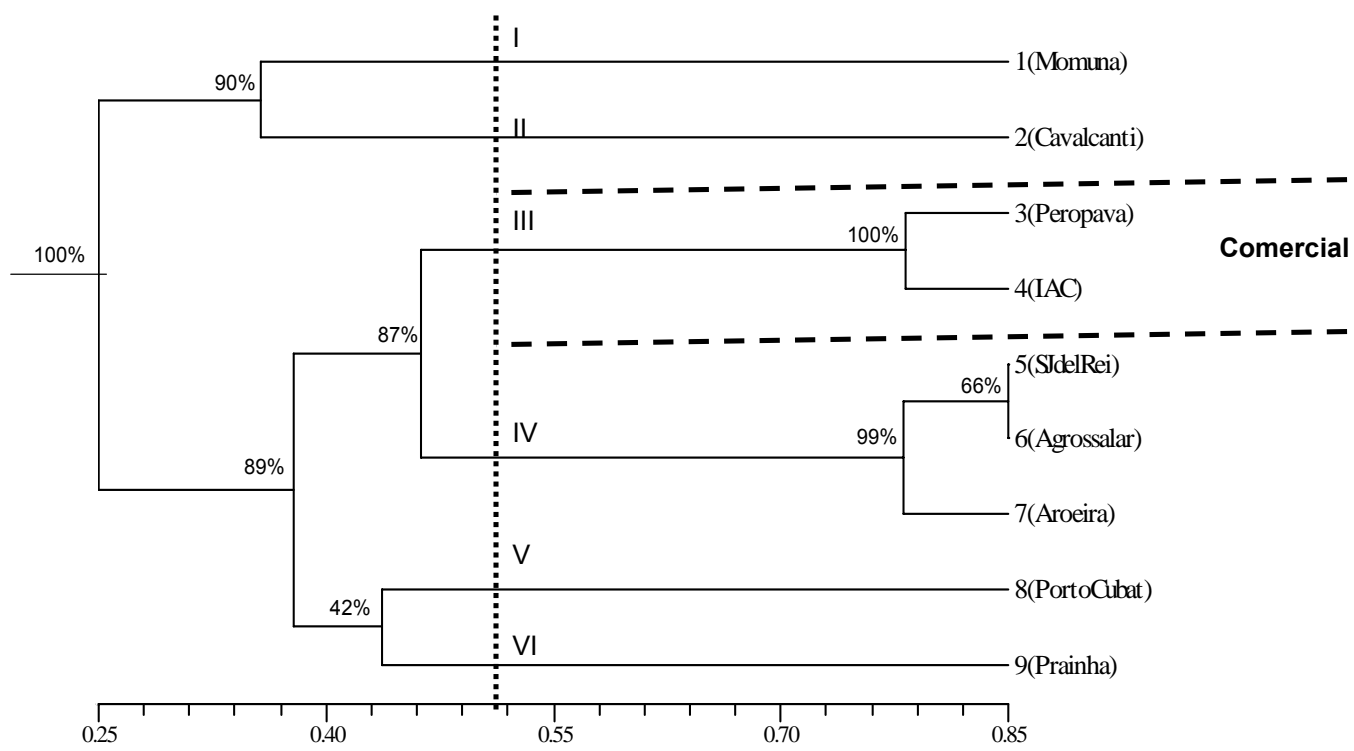

Figura 19 - Análise de agrupamento pelo método aglomerativo UPGMA relativo a sete comunidades e dois locais que cultivam a espécie $D$. bulbifera, com base em 67 bandas isoenzimáticas, de acordo com a similaridade do índice de Jaccard. Piracicaba-SP, 2005

O coeficiente obtido pela correlação entre distância genética e distância geográfica foi positivo $(r=0,41)$, mas não significativo $(p=1,00)$, mostrando que a diversidade não está estruturada no espaço. Esses resultados, quando comparados com os obtidos para $D$. trifida, demonstram que os agricultores tradicionais do Vale do Ribeira são elementos importantes na distribuição da variabilidade das duas espécies de inhame pela região.

Para a análise de variância molecular (AMOVA), os dados dos acessos do IAC e São João Del Rei formam retirados, pois o objetivo desta pesquisa era analisar somente a distribuição da diversidade isoenzimática das etnovariedades originárias no Vale do Ribeira. Com base nos dados de 67 bandas polimórficas esta análise, verificou-se que a variabilidade encontra-se distribuída em sua maior parte entre as roças dentro de comunidades $(64,76 \%)$ e entre comunidades $(20,51)$, ressaltando, desta forma, a importância das unidades biológicas (roças) na distribuição da diversidade genética (Tabela 13). 
Tabela 13. Resultados da análise de variância molecular (AMOVA) para D. bulbifera. Piracicaba-SP, 2005

\begin{tabular}{cccc}
\hline Fonte de variação & GL & SQ & $\begin{array}{c}\text { Porcentagem da variação } \\
\text { total }\end{array}$ \\
\hline Entre comunidades & 6 & 112,35 & 20,51 \\
Entre roças dentro de comunidades & 3 & 33,42 & 64,76 \\
Dentro de roças dentro de & 7 & 12,00 & 14,73 \\
comunidades & & & \\
Total & 16 & 157,77 & \\
\hline
\end{tabular}

A distribuição da variabilidade entre e dentro das unidades evolutivas sugere quais fatores podem interferir na distribuição geográfica de $D$. bulbifera, visando a formulação de hipóteses genético-evolutivas nas roças de agricultura tradicional do Vale do Ribeira. Trabalhos similares forma realizados com a cultura da mandioca em roças de agricultores tradicionais do litoral do Estado de São Paulo (Peroni, 1998; Sambatti et al., 2001), onde se observou que a maior parte da diversidade encontra-se dentro de roças. Este resultado era esperado para $D$. bulbifera, pois, em geral, apenas uma etnovariedade era encontrada em cada roça, de onde coletou-se apenas um tubérculo.

\subsubsection{Avaliação morfológica}

A utilização de descritores morfológicos na caracterização da variabilidade genética de acessos de inhame tem trazido bons resultados como informam os estudos de Rhodes \& Martin (1972) e Onyilagha (1986).

Os métodos hierárquicos de agrupamento relativo a 17 etnovariedades, seis acessos do IAC e um acesso de São João Del Rei de $D$. bulbifera, com base em 24 caracteres morfológicos, revelou a formação de sete grupos (I a VII), nos quais os acessos foram distribuídos da seguinte forma: I (1, 3, 5, 6, 7, 8, 9, 10, 11, 12, 13, 14 , 15, e 16); II (4); III (7); IV (18); V (19, 20, 21 e 22); VI (23) e VII (2) (Figura 20). 


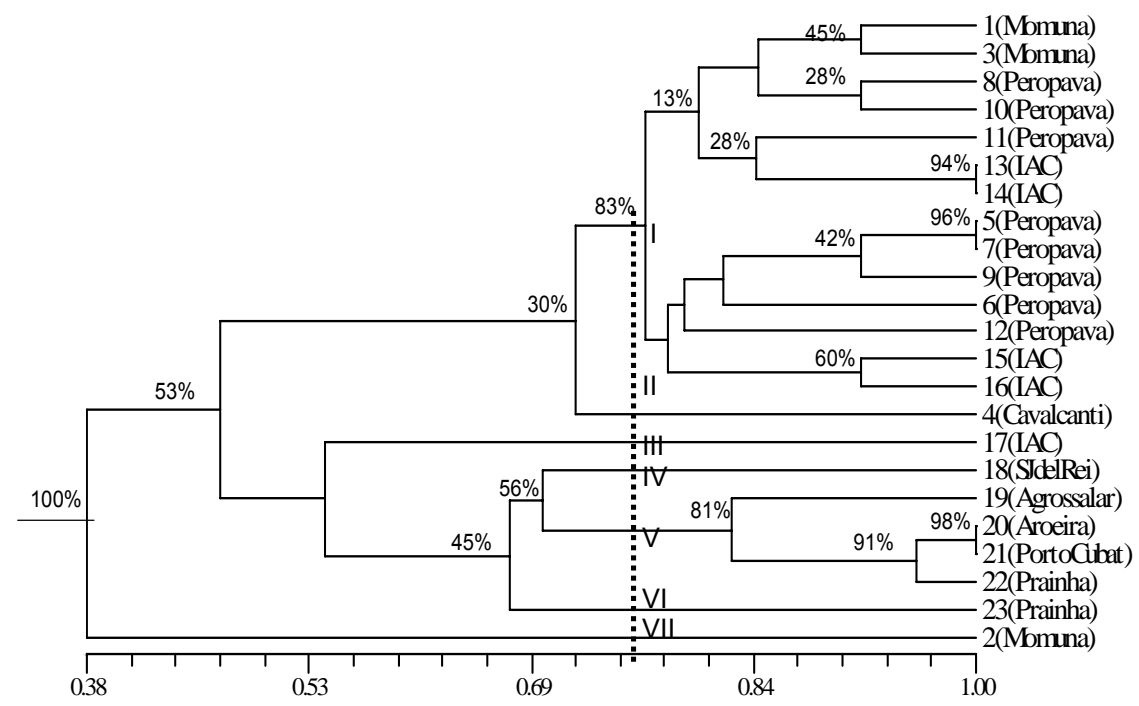

Figura 20 - Análise de agrupamento pelo método aglomerativo UPGMA relativo a 17 etnovariedades, seis acessos do IAC e um acesso de São João Del Rei de $D$. bulbifera, com base em 24 caracteres morfológicos, de acordo com a similaridade do índice de Jaccard. Piracicaba-SP, 2005

O coeficiente de similaridade de Jaccard para os dados morfológicos entre os indivíduos 13 e 14 do IAC, 5 e 7 da roça 5 na comunidade de Peropava e 20 e 21 das comunidades de Aroeira e Porto Cubatão foram iguais a 1. Esses indivíduos apresentaram, portanto, o mesmo fenótipo morfológico (Tabela 5; Figura 20).

Pelas análises de agrupamento das etnovariedades e acessos comerciais, verificou-se a não separação dos materiais como ocorreu na avaliação isoenzimática. Nas análises morfológicas também não verificou-se a distinção das etnovariedades por unidades culturais (comunidades) como ocorreu nas análises isoenzimáticas em $D$. bulbifera e para a espécie $D$. trifida.

Dos dendrogramas pode-se retirar também as amplitudes de similaridades para os materiais. A amplitude de similaridade variou de 1,00 a 0,38, indicando, desta forma, que as etnovariedades possuem uma variação de similaridade de $62 \%$, para os caracteres morfológicos. 
$\mathrm{Na}$ análise de agrupamento entre as comunidades que cultivam $D$. bulbifera observou-se a formação de quatro grupos (I a IV), nos quais as comunidades foram distribuídas da seguinte forma: I (Momuna); II (Cavalcanti, Peropava, IAC e São João Del Rei); III (Agrossolar e Prainha) e IV (Aroeira e Porto Cubatão) (Figura 21).

As amplitudes de similaridade de Jaccard variaram para esta análise de agrupamento de 1,00 a 0,52 indicando, desta forma, que estas possuem uma variação de similaridade de $48 \%$, ou seja, existe grande diversidade entre as unidades culturais quanto à morfologia.

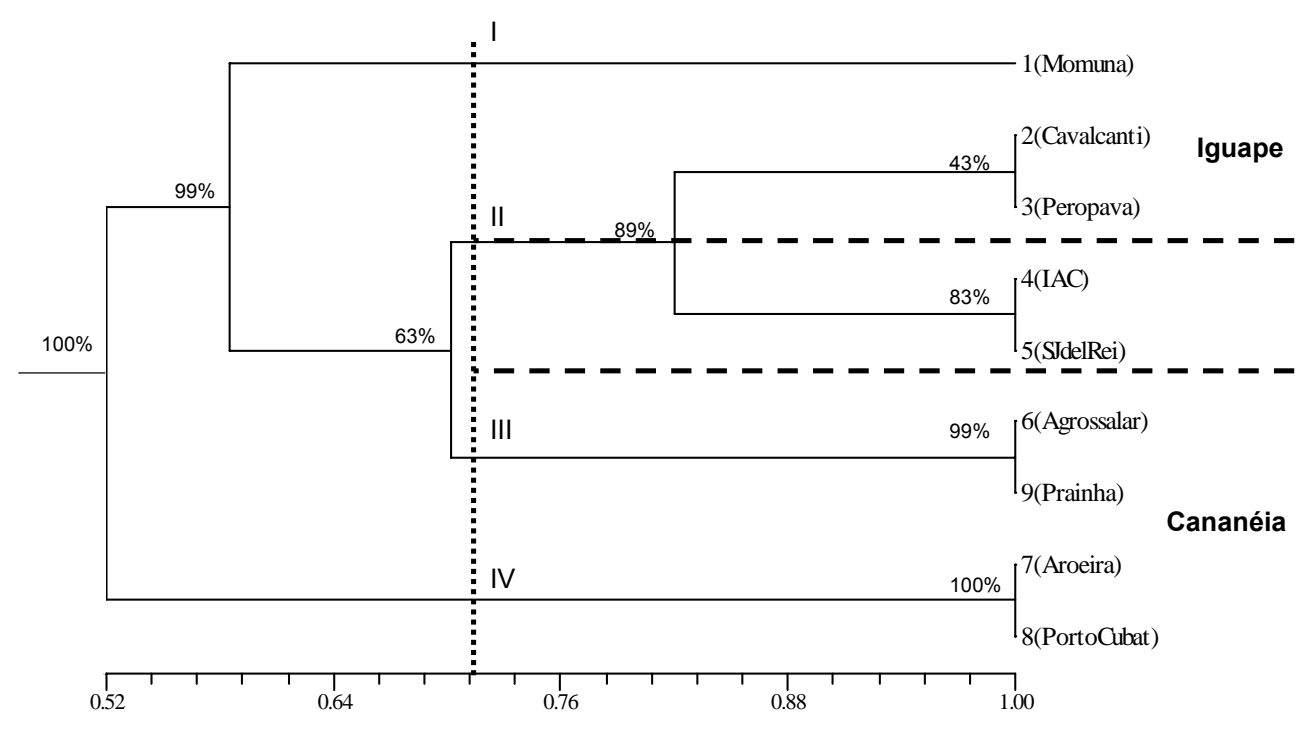

Figura 21 - Análise de agrupamento pelo método aglomerativo UPGMA relativo a 9 comunidades e dois locais que cultivam $D$. bulbifera, com base em 24 características morfológicas, de acordo com a similaridade do índice de Jaccard. Piracicaba-SP, 2005

Verificou-se também a separação das comunidades dos municípios de Iguape e Cananéia devido ao inter-relacionamento das unidades evolutivas, pois os agricultores do primeiro município selecionam os materiais vegetais para características como comprimento do pecíolo $(>10 \mathrm{~cm}$ ) e cor do pecíolo (verde), enquanto que os de Cananéia preferem pecíolos com 5 a $10 \mathrm{~cm}$ e distância entre a inserção do pecíolo na folha à extremidade superior da folha (L2) de 10 a $15 \mathrm{~cm}$, ou seja, observou-se a separação das etnovariedades de acordo com o conhecimento cultural dos agricultores 
de ambos os municípios. Contudo, o nome comum "cará moela" utilizado pelos agricultores encobre a diversidade existente de acordo com suas preferências culturais.

O coeficiente obtido pela correlação entre distância genética e distância geográfica foi positivo $(r=0,17)$, mas não significativo $(p=0,99)$, sugerindo a inexistência de relação entre esses dois parâmetros analisados. Desta forma, a divergência morfológica para a espécie não pode ser explicada pela distribuição geográfica mesmo que tenha ocorrido a separação das comunidades de Cananéia por questões de conhecimento cultural dos agricultores.

Com base nos dados de 24 caracteres morfológicos utilizando a análise de variância molecular (AMOVA) verificou-se que a maior parte da variabilidade encontrase distribuída entre as roças dentro de comunidades $(44,27 \%)$ bem como dentro de roças $(38,87 \%)$ (Tabela 14$)$. Esta grande variação dentro de roças se deve a diferenças morfológicas observadas entre os acesso de Peropava, todos coletados em uma mesma roça. Já para isoenzimas, apenas um acesso se diferenciou dos demais em Peropava.

Tabela 14. Resultados da análise de variância molecular (AMOVA) para os dados morfológicos para D. bulbifera. Piracicaba-SP, 2005

\begin{tabular}{cccc}
\hline Fonte de variação & GL & SQ & $\begin{array}{c}\text { Porcentagem da variação } \\
\text { total }\end{array}$ \\
\hline Entre comunidades & 6 & 56,41 & 15,86 \\
Entre roças dentro de comunidades & 3 & 18,71 & 44,27 \\
Dentro de roças dentro de & 7 & 18,29 & 38,87 \\
comunidades & & & \\
Total & 16 & 93,41 & \\
\hline
\end{tabular}

A percepção humana local exerce grande influencia na diversidade morfológica para a espécie $D$. bulbifera, uma vez que o agricultor seleciona principalmente as características qualitativas como a cor da polpa do tubérculo, formato, tipo de folha, etc. Portanto, os agricultores adaptam as culturas agrícolas aos seus usos e valores culturais. Peroni (1998) também cita a seleção perceptiva dos agricultores tradicionais do Vale do Ribeira sobre a variabilidade genética de etnovariedades de mandioca. 


\subsubsection{Correlação entre estimativas isoenzimáticas e morfológicas}

Estimou-se a correlação entre distância isoenzimática e morfológica que foi pequena $(r=0,19)$, mas não significativa $(p=0,96)$, indicando que não existe correlação entre esses dois parâmetros.

Dos acessos contendo o mesmo fenótipo isoenzimático, apenas dois pares de acessos também mostraram-se idênticos morfologicamente, ou seja, os acessos 13 e 14 do IAC e 5 e 7 da roça 5 na comunidade de Peropava. Já os acessos 20 e 21 das comunidades de Aroeira e Porto Cubatão, que mostraram-se idênticos morfologicamente, apresentam padrões fenotípicos diferentes e foram classificados em grupos distintos no dendrograma para análises isoenzimáticas.

\subsection{Conclusões}

Os marcadores isoenzimáticos e morfológicos revelaram que, além da grande diversidade genética das etnovariedades, os agricultores tradicionais cultivam alguns materiais comerciais em suas roças. Isto pode estar ligado ao fato de que alguns agricultores os cultivam com o intuito de comercializar sua produção.

Os marcadores isoenzimáticos foram mais informativos que os morfológicos, pois ficou claro a separação entre as etnovariedades e os materiais comerciais de $D$. bulbifera.

O nome comum "cará moela" encobre grandes níveis de diversidade entre e dentro de roças, comunidades e municípios.

A maior parte da diversidade, mesmo não estruturada no espaço, encontra-se entre roças dentro de comunidades do Vale do Ribeira.

Recomenda-se, para estudos futuros, o detalhamento do conhecimento popular sobre uma etnovariedade denominada "cará preto" como produto medicinal. 


\section{DIVERSIDADE ISOENZIMÁTICA E MORFOLÓGICA DE Dioscorea alata EM ROÇAS DE AGRICULTURA TRADICIONAL DO VALE DO RIBEIRA - SP}

\section{Resumo}

O inhame (Dioscorea spp.) é uma hortaliça com expressivo consumo mundial principalmente em países em desenvolvimento. Os agricultores tradicionais do Vale do Ribeira da região sul do Estado de São Paulo cultivam diversas etnovariedades de $D$. alata. O presente estudo teve como objetivo avaliar a diversidade genética, por meio de marcadores isoenzimáticos e morfológicos, de 16 etnovariedades e 19 materiais comerciais de $D$. alata, verificando como esta se distribui nos diferentes níveis de organização, como roças e comunidades do Vale do Ribeira. Para as análises isoenzimáticas, foram utilizados géis de poliacrilamida (seis sistemas enzimáticos) e amido (um sistema) e para os marcadores morfológicos foram avaliados 24 caracteres. Devido à natureza poliplóide do inhame os materiais foram genotipados gerando dados binários. Os dados morfológicos também foram analisados por meio de notas transformados em uma matriz binária. Para ambos os dados foi calculado o índice médio de similaridade de Jaccard entre pares de indivíduos e obtidos dendrogramas pelo critério de agrupamento UPGMA para variedades, roças e comunidades. Pelas análises de agrupamento houve a separação dos materiais comerciais das etnovariedades coletadas nas roças tradicionais do Vale do Ribeira para ambos os marcadores. A correlação entre as matrizes de distância genética e geográfica foi negativa $(r=-0,11)$, mas não significativa estatisticamente para isoenzimas, sugerindo que não existe correlação entre esses dois parâmetros. Foi também realizada a análise de variância molecular (AMOVA) e pôde-se verificar que a maior parte da variabilidade isoenzimática encontrava-se dentro de roças dentro de comunidades $(53,99 \%)$. A correlação entre as distâncias morfológicas e geográficas também indicou que a diversidade não está estruturada no espaço $(r=0,03)$. De acordo com a AMOVA, a 
maior parte da variabilidade morfológica encontrava-se dentro de roças dentro de comunidades $(70,11 \%)$. Correlacionando-se as estimativas isoenzimáticas e morfológicas chegou-se a uma correlação positiva $(r=0,27)$, mas não significativa estatisticamente. Os marcadores isoenzimáticos e morfológicos revelaram que os agricultores tradicionais cultivam grande diversidade de $D$. alata em suas roças. A maior parte da diversidade, mesmo não estruturada no espaço, encontra-se dentro das roças dos agricultores tradicionais. 


\section{ISOENZYMATIC AND MORPHOLOGICAL DIVERSITY OF Dioscorea alata IN SWIDDENS OF TRADITIONAL AGRICULTURE OF THE RIBEIRA RIVER VALLEY- SP}

\section{Summary}

Yam (Dioscorea spp.) is a vegetable of expressive world consumption mainly in developing countries. Traditional agriculturists of the Ribeira River Valley in the south region of the State of São Paulo cultivate several $D$. alata ethnovarieties. The objective of this study was to evaluate the genetic diversity of 16 ethnovarieties and 19 commercial varieties of $D$. alata, through isozymic and morphological markers, assessing its distribution in the different levels of organization, such as swiddens and communities of the Ribeira River Valley. The isozyme analyses were conducted with polyacrylamide (six enzyme systems) and starch gels (one enzyme system), and the morphological analyses were carried out with 24 characters. Due to the polyploid nature of yams the material was scored as binary data. The morphological data were also transformed into a binary matrix. Cluster analyses were conducted for ethnovarieties, swiddens and communities using the Jaccard similarity index among pairs of individuals and the UPGMA clustering method. The cluster analyses for both markers classified in separate groups the commercial accessions from the ethnovarieties collected in the traditional swiddens of the Ribeira River Valley. The correlation between the genetic and geographical distance matrices was negative $(r=-0.11)$ and non statistically significant for the isozyme markers, suggesting that both parameters are not correlated. The analysis of molecular variance (AMOVA) indicated that most of the isozymic variability was concentrated within swiddens within communities (53.99\%). The correlation between the geographical and the morphological genetic distances $(r=$ 0,03 ) indicated that the morphological diversity was not structured in space. According to the AMOVA, most of the morphological variability was concentrated within swiddens within communities $(70.11 \%)$. The correlation between isozymic and morphological markers was positive $(r=0.27)$ but not statistically significant. The isozymic and morphological markers revealed that the traditional agriculturists cultivate high diversity of $D$. alata ethnovarieties in their swiddens. Most of the diversity, although not structured in space, was found within swiddens of the traditional agriculturists. 


\subsection{Introdução}

O inhame (Dioscorea spp.) é uma hortaliça com expressivo consumo mundial principalmente nos países em desenvolvimento. É um alimento rico em carboidratos, proteínas, fósforo, cálcio, ferro e vitaminas $B_{1}$ e $B_{2}$ (Abramo, 1990).

A espécie $D$. alata L. (cará alado ou cará d'água), é originária do sudeste asiático, onde foi domesticada pelos Semang, pigmeus que habitavam a Birmânia e Indonésia. Esses povos difundiram os inhames para grande parte da Oceania. Posteriormente, esta espécie foi difundida também para a África entre os séculos VI e $X$ e daí levada para a América no século XVI, através do tráfico negreiro. No Brasil, acredita-se que a maior expansão do plantio processou-se do litoral em direção ao interior (Pedralli, 1988).

D. alata é a espécie mais conhecida para o cultivo no Estado de São Paulo, cujas variedades são classificadas vulgarmente como cará-Mimoso (tubérculos com polpa amarela, casca lisa e alongados), cará-Flórida (tubérculos cilíndricos, casca marrom-claro e polpa granulosa) e caipira (tubérculos de má aparência, pequenos e casca escura). No Estado de São Paulo essas variedades são cultivadas comercialmente por agricultores convencionais (Murayama, 1999).

Os agricultores tradicionais da região sul do Estado de São Paulo, que praticam a agricultura de coivara, cultivam diversas etnovariedades desta espécie, utilizados em grande parte para sua subsistência. Algumas roças tradicionais também cultivam etnovariedades de $D$. alata para o comércio local seguindo o mesmo modelo do cultivo de subsistência, ou seja, caracterizado por baixo dispêndio de energia e intenso trabalho familiar.

Esse sistema de produção agrícola que coexiste com a Mata Atlântica chamou atenção do Prof. Dr. Paulo Sodero Martins (in memorian) do Departamento de Genética da Escola Superior de Agricultura "Luiz de Queiroz" que durante a década de 90 iniciou os estudos de evolução de plantas cultivadas pelos agricultores tradicionais do Vale do Ribeira. A primeira espécie estudada através de análises morfológicas e isoenzimáticas foi a mandioca (Manihot esculenta Crantz) destacando-se os trabalhos de Cury (1993, 1998), Peroni (1998), Faraldo (1994, 1999), Silva (2000), Sambatti et al. (2001) e Silva et al. (2003). 
A mandioca possui grande importância na alimentação dos agricultores tradicionais, confirmado por Peroni \& Hanazaki (2002) que estudaram a contribuição das etnovariedades nas roças que empregam o sistema de coivara. Das 261 variedades de 53 espécies cultivadas pelos agricultores tradicionais do Vale do Ribeira, a mandioca apresentou 62 variedades seguidas pelo inhame (Dioscorea spp.) e batatadoce (Ipomoea batatas) com 29 variedades.

Para a cultura do inhame, a caracterização isoenzimática visando o estudo genético foi realizada na África com sucesso destacando-se os trabalhos do complexo D. cayenensis/rotundata de Hamon \& Toure (1990), Zoundjihekpon et al. (1994) e Dansi et al. (2000). A espécie $D$. alata foi estudada através da técnica de isoenzimas por Twyford (1990). Já para a caracterização morfológica baseada na lista de descritores preconizados pelo IPGRI e IITA na Nigéria, destacam-se os trabalhos de Onyilagha (1986) com D. rotundata e Rodhes \& Martin (1972) para a espécie D. alata. Utilizando ambos marcadores isoenzimáticos e morfológicos para cultivares de inhame (D. cayenensis/rotundata), destaca-se o trabalho de Mignouna et al. (2002).

Este estudo visa dar continuidade ao trabalho proposto pelo Prof. Sodero Martins estendendo as hipóteses do modelo de dinâmica evolutiva proposto para mandioca para espécies de reprodução vegetativa como o inhame (Dioscorea spp). Portanto, o presente trabalho teve como objetivo avaliar a diversidade genética, por meio de marcadores isoenzimáticos e morfológicos, de variedades de $D$. alata, além de verificar de que forma esta diversidade se distribui nos diferentes níveis de organização como roças e comunidades do Vale do Ribeira, verificando-se a existência de correlação entre as distâncias geográficas e as distâncias genéticas (isoenzimas e morfologia) e entre as distâncias genéticas dos dois marcadores.

\subsection{Material e Métodos}

Foram coletadas 16 etnovariedades de $D$. alata junto às comunidades que praticam a agricultura tradicional nos municípios de Cananéia $\left(25^{\circ} 00^{\prime} \mathrm{S}\right.$ e $\left.47^{\circ} 55^{\prime} \mathrm{W}\right)$,

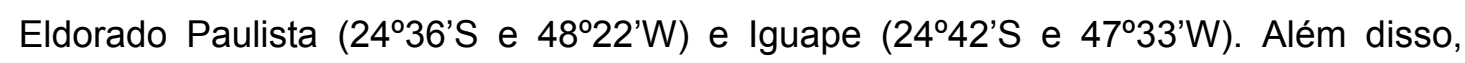
utilizaram-se dois materiais provenientes da coleção do Instituto Agronômico de

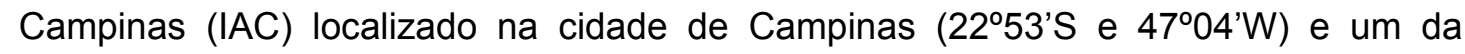
Embrapa Mandioca e Fruticultura Tropical. Utilizou-se também 16 materiais comerciais 
provenientes de varejões dos municípios de Iguape (244ㄴ 'S e $\left.47^{\circ} 33^{\prime} \mathrm{W}\right)$, Santa Rosa

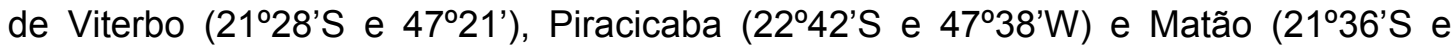
$\left.48^{\circ} 22^{\prime} \mathrm{W}\right)$, além de uma fazenda produtora no município de Araras $\left(22^{\circ} 21 \mathrm{~S}\right.$ e $\left.47^{\circ} 23^{\prime} \mathrm{W}\right)$ para comparar com a diversidade manejada pelos agricultores tradicionais do Vale do Ribeira (Tabela 4).

Coletou-se um tubérculo de cada roça, com exceção das roças 15, 17 e 21 nas comunidades de Aroeira e Rio Branco no município de Cananéia e Sapatu em Eldorado Paulista, respectivamente, que possuíam mais de uma etnovariedade identificada como diferente pelo agricultor. O número médio de etnovariedades por roça foi 1,2. Esses materiais foram trazidos para o Departamento de Genética da Escola Superior de Agricultura "Luiz de Queiroz" da Universidade de São Paulo, em Piracicaba-SP $\left(22^{\circ} 43^{\prime} S\right.$ e $\left.47^{\circ} 43^{\prime} \mathrm{W}\right)$ e plantados em vasos e mantidos em casa-devegetação em uma primeira etapa de brotação e quarentena. Dois meses após, as mudas foram transplantadas para um campo experimental em camalhões. O espaçamento entre fileiras e entre plantas foi de $1,50 \mathrm{~m}$. Para a condução das plantas utilizaram-se varas de bambu de aproximadamente $1,80 \mathrm{~m}$, visando orientar o crescimento das plantas.

Esses acessos foram analisados por meio de marcadores isoenzimáticos e morfológicos, visando verificar como se distribui a diversidade genética nos diferentes níveis hierárquicos: dentro de roças e quintais (unidade básica evolutiva), entre roças e quintais dentro de comunidades (unidade cultural) e entre comunidades do Vale do Ribeira. Além disso, buscou-se comparar as etnovariedades com os acessos dos bancos de conservação ex situ do IAC, Embrapa e materiais comerciais. Para esta pesquisa convencionou-se que as unidades básicas evolutivas roças e quintais serão analisadas apenas como "roças".

\subsubsection{Análise isoenzimática}

A estimação da diversidade para $D$. alata, do banco de conservação ex situ da ESALQ/USP, foi realizada através da técnica de eletroforese de isoenzimas (Soltis \& Soltis, 1990). O protocolo para extração e visualização das formas moleculares de uma mesma enzima foi adaptado e utilizado na avaliação genética com base nos padrões isoenzimáticos dos acessos estudados. 
As enzimas foram extraídas a partir de amostras de folhas jovens (recém expandidas) de plantas adultas (6-8 meses), as quais foram pesadas $(0,2 \mathrm{~g})$ e maceradas em nitrogênio líquido $\left(-96^{\circ} \mathrm{C}\right)$ em microtubos de 1,5 . Foi utilizado $1 \mathrm{~mL}$ de solução extratora acrescida de $3 \%$ de mercaptoetanol, visando minimizar os danos da oxidação. O macerado resultante foi centrifugado a $15.000 \mathrm{rpm}(23.000 \mathrm{~g})$ por 20 minutos em uma centrifuga refrigerada a $4^{\circ} \mathrm{C}$ (Figuras 12; 13).

Foram utilizados géis de amido e poliacrilamida. No caso do gel de poliacrilamida, foi utilizado nas canaletas do gel polimerizado, uma alíquota de $25 \mu \mathrm{L}$ do extrato bruto (sobrenadante) misturado com $250 \mu \mathrm{L}$ de solução de azul de bromofenol, o qual serviu como parâmetro para a avaliação da migração das proteínas no gel. No caso do gel de amido, o sobrenadante era absorvido por pedaços de papel de filtro. Estes papéis foram colocados verticalmente no gel (lado a lado). Nas extremidades foram colocados papéis embebidos na solução de azul de bromofenol, o qual também serviu como parâmetro para a avaliação da migração das proteínas no gel. O restante do sobrenadante foi descartado devido à rápida degradação das enzimas do inhame. Os géis tanto de amido como poliacrilamida foram preparados de acordo com os itens 4.2.1.2 e 4.2.1.3.

Dezoito sistemas isoenzimáticos foram testados (Tabela 7), sendo que os principais critérios para a escolha dos sistemas que seriam utilizados foram a resolução, presença de polimorfismo, repetibilidade e interpretabilidade. Selecionaramse os seguintes sistemas enzimáticos: $\mathrm{MDH}$ para o gel de amido e para o gel de poliacrilamida PGM, G ${ }_{6} \mathrm{PDH}, \mathrm{GPI}, \mathrm{SOD}, \mathrm{SKDH}$ e ATT (Apêndice 1).

Após a migração das enzimas através dos géis de amido e poliacrilamida foi realizada a revelação histoquímica das enzimas, conforme o protocolo do Laboratório de Ecologia Evolutiva e Genética Aplicada (LEEGA) do Departamento de Genética, USP/ESALQ.

\subsubsection{Análise morfológica}

As avaliações morfológicas foram realizadas no campo experimental do Departamento de Genética da ESALQ/USP, visando manter as mesmas condições bióticas e abióticas o que não seria possível nas roças dos agricultores tradicionais no Vale do Ribeira. 
Utilizou-se na caracterização morfológica os descritores preconizados pelo International Plant Genetic Resources Institute (IPGRI) e International Institute of Tropical Agriculture (IITA), em Ibadan, Nigéria, descritos com suas respectivas escalas, em IPGRI/IITA (1997). Nem todos os descritores preconizados para as espécies de Dioscorea foram utilizados para avaliação morfológica de $D$. alata.

Para a caracterização das 16 etnovariedades e 19 acessos de $D$. alata do banco de germoplasma da ESALQ/USP, foram avaliados 24 descritores morfológicos, sendo nove associados a características de folha, seis para o caule, sete para tubérculos e um para o florescimento (Tabelas 8, 9 e 10). Essas observações foram baseadas na média fenotípica de 10 medições dos descritores quantitativos para folhas, caules e tubérculos de cada planta individual. Estes foram transformados em notas, conforme descritos nas Tabelas 8, 9 e 10. Os dados qualitativos foram também avaliados atribuindo-se notas. No total foram avaliados nove descritores quantitativos e 15 qualitativos.

As avaliações morfológicas foram realizadas em duas etapas, sendo a primeira aos seis meses após o transplantio dos acessos no campo, pois nesta época havia disponibilidade suficiente de tecidos (folhas jovens, adultas e ramos) e a segunda durante a colheita quando os tubérculos, já formados, foram avaliados.

\subsubsection{Análise estatística}

Devido a natureza poliplóide da espécie $D$. alata não foi possível a avaliação dos materiais em termos de locos e alelos ou mesmo por freqüências alélicas e genotípicas. Os materiais foram, portanto, genotipados como dados binários (presença = 1 e ausência $=0$ ), gerando uma matriz binária. Os dados morfológicos também foram analisados por meio de notas, transformados em dados binários. Para as análises isoenzimáticas foram calculados os números de bandas por sistema, número total de bandas e porcentagem de bandas polimórficas.

Para ambos os marcadores foram calculados os índices de similaridade de Jaccard entre pares de indivíduos com base nas matrizes binárias dos dados isoenzimáticos e morfológicos. A estimação da variabilidade foi visualizada a partir dos 
índices médios de similaridade e dos dendrogramas baseados no método de agrupamento UPGMA para variedades, roças (Apêndices $6 ; 7$ ) e comunidades.

Adotou-se para a formação dos grupos o limite mínimo de $50 \%$ de similaridade para os marcadores isoenzimáticos e $70 \%$ para os marcadores morfológicos entre as variedades, roças e comunidades para que fossem incluídas no mesmo grupo.

A avaliação da estabilidade dos agrupamentos dos dendrogramas foi baseada em estimativas de dissimilaridades genéticas através do procedimento de reamostragens com 1.000 bootstraps empregando o programa BOOD versão $2.0 \mathrm{e}$ BOOD-P (Coelho, 2001, 2003). Neste programa, os valores superiores a $50 \%$ nos "nós", que unem os grupos, indicam que as distâncias genéticas entre as unidades biológicas de um mesmo grupo são estáveis.

Com o objetivo de simplificar a análise, foi realizada uma comparação apenas entre as roças e outra apenas para comunidades. As roças foram analisadas através da média da matriz de similaridade de Jaccard das etnovariedades dando origem a uma matriz, utilizada para estudar a variabilidade das roças a partir dos agrupamentos formados. Da mesma forma, as comunidades foram analisadas através da média da matriz de similaridade gerada para roças.

Contudo, a análise de agrupamento traz como conseqüência a perda de informações unitárias (acessos) restando apenas as informações sobre os grupos similares. Dessa forma, as informações foram complementadas com ferramentas como a análise de variância molecular (AMOVA) e a correlação de Pearson (r).

As matrizes binárias dos dados isoenzimáticos e morfológicos foram utilizadas para a análise de variância molecular (AMOVA) que deve ser entendida como uma sumarização da diversidade molecular e morfológica, visando entender como se situa a distribuição da diversidade, de acordo com os níveis hierárquicos. A AMOVA foi utilizada somente para os materiais coletados nas roças dos agricultores tradicionais do Vale do Ribeira. Para tanto, utilizaram-se as distâncias ao quadrado, conforme descrito por Excoffier et al. (1992) com o auxílio do programa Arlequin (Schneider et al., 2004).

Com a finalidade de analisar os padrões de variação espacial, buscou-se correlacionar a diversidade genética (isoenzimática e morfológica) com a estrutura espacial, para tentar entender a dinâmica evolutiva da cultura dentro dos sistemas agrícolas tradicionais do Vale do Ribeira, pois as espécies sofrem pressão de forças 
evolutivas que podem atuar conjunta ou isoladamente em diferentes intensidades determinando, desta forma, a existência ou não de um paralelismo entre as distâncias genéticas e geográficas. O coeficiente utilizado foi a correlação de Pearson $(r)$ através das matrizes de distâncias genéticas calculadas pelo índice de similaridade de Jaccard e as distâncias geográficas entre as espécies. A distância geográfica foi estimada a partir das coordenadas originais das roças e quintais utilizando o programa TrackMaker versão 12.3 (Ferreira Junior, 2004).

A correlação de Pearson ( $r$ ) também foi utilizada para verificar a associação entre a diversidade molecular (dados isoenzimáticos) e a diversidade morfológica. $O$ nível de significância das correlações foi testada pelo método estatístico de Mantel ( $Z$ ), utilizando 1.000 permutações aleatórias (Zucchi, 2002). Para a construção da matriz de similaridade e aplicação do teste de Mantel utilizou-se o programa NTSYSpc versão 2.0 (Rohlf, 1992).

\subsection{Resultados e Discussão}

\subsubsection{Análise isoenzimática}

O sistema SOD apresentou o maior número de bandas (13) seguido pelo PGI e MDH com 12, GOT com 10, G 6 PDH com 9, SKDH com 8 e PGM com 7, num total de 71 bandas para todos os sistemas. Além disso, observou-se que $100 \%$ das bandas eram polimórficas. A combinação das diferentes bandas isoenzimáticas de todas as enzimas avaliadas nos dois tipos de géis (amido e poliacrilamida) discriminou as 16 etnovariedades e 13 materiais comerciais (padrões) dos 19 analisados.

A espécie $D$. alata foi estudada através da técnica de isoenzimas por Twyford (1990), que permitiu a identificação de materiais provenientes de cultura de tecidos das espécies $D$. alata, $D$. cayenensis/rotundata, $D$. esculenta e $D$. bulbifera. Asiedu et al. (2005) estudaram 3.000 acessos (etnovariedades) de 10 países africanos do inhame branco ( $D$. rotundata Poir.) utilizando marcadores moleculares (isoenzimas, Amplified Fragment Length Polymorphism - AFLP, Random Amplification of Polymorphic DNA RAPD e microssatélites - SSR) em sincronia com marcadores morfológicos, visando identificar materiais tolerantes à seca. 
No Brasil, este é o primeiro relato sobre a estimação da diversidade isoenzimática observada entre etnovariedades de $D$. alata cultivadas por agricultores tradicionais do Vale do Ribeira. O dendrograma relativo aos 35 acessos de $D$. alata do banco de conservação ex situ do ESALQ/USP revelou a formação de treze grupos (I a XIII), nos quais os acessos foram distribuídos da seguinte forma: I (1 e 2); II (3); III (4); IV (31, 32 e 33); V (5); VI (34); VII (27), VIII (25), IX (6, 23, 24 e 28), X (7, 8, 9, 10, 11, $12,13,14,15,16,17,18,19,20,21$ e 22), XI (26), XII (29 e 30) e XIII (35) (Figura 22).

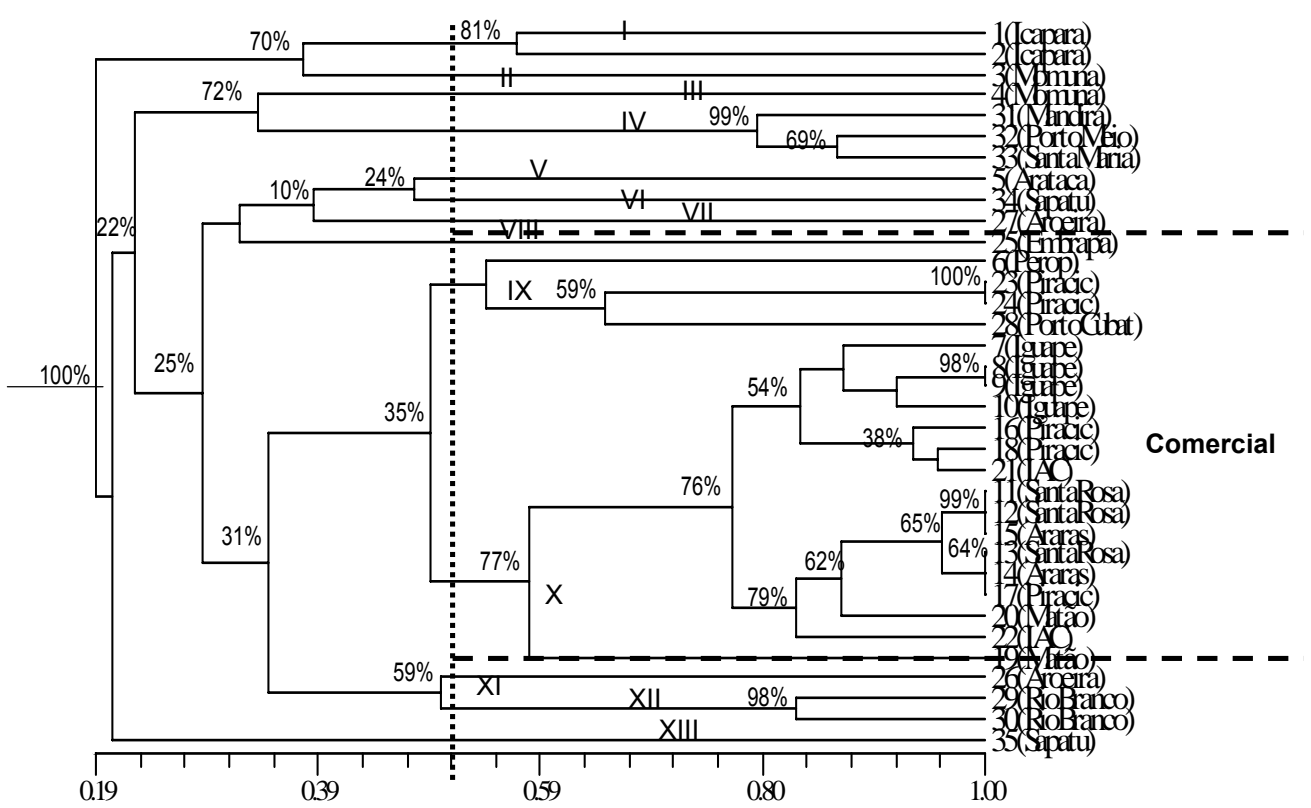

Figura 22 - Análise de agrupamento pelo método aglomerativo UPGMA relativo a 16 etnovariedades e 19 acessos de $D$. alata, com base em 71 bandas isoenzimáticas, de acordo com a similaridade do índice de Jaccard. Piracicaba-SP, 2005

O coeficiente de similaridade de Jaccard entre os materiais comerciais 23 e 24 de Piracicaba apresentou coeficiente de similaridade igual a 1, ou seja, apresentaram o mesmo fenótipo isoenzimático. O mesmo ocorreu para os indivíduos 8 e 9 do varejão de Iguape, 11, 12 e 15 do varejão de Santa Rosa de Viterbo e da Fazenda Pastre no município de Araras e entre os indivíduos 13, 14 e 17 dos municípios de Santa Rosa 
de Viterbo, Araras e Piracicaba (Tabela 5). Esses materiais apresentam o mesmo fenótipo, pois são materiais comercializados nas feiras, varejões e supermercados do Estado de São Paulo através do CEASA.

Observa-se na Figura 23 uma separação nítida entre as etnovariedades (grupos I a VII e XI a XIII) e os materiais comerciais (grupos VIII a X), incluindo os acessos originados da Embrapa e do IAC e de duas etnovariedades de Peropava e Porto Cubatão. O agricultor de Peropava relatou, por ocasião da coleta, que adquiria suas variedades no CEASA, no município de São Paulo, o que explica sua proximidade ao grupo das variedades comerciais. Os materiais comerciais possuem menor diversidade entre si (amplitude de similaridade de 55\%), enquanto que as etnovariedades apresentam maior diversidade $(71 \%)$. Já a amplitude de similaridade total variou de 1,00 a 0,19 indicando, desta forma, que os acessos avaliados possuem $81 \%$ de variabilidade, ou seja, existe grande diversidade entre os acessos de $D$. alata.

A análise realizada em nível de comunidades, os agrupamentos revelaram a formação de dez grupos ( $\mathrm{I}$ a X), nos quais as comunidades e os pontos de coleta foram distribuídos da seguinte forma: I (Icapara); II (Momuna); III (Arataca); IV (Aroeira); V (Rio Branco); VI (Sapatu); VII (Peropava, IAC, Iguape, Santa Rosa, Araras, Piracicaba 1, Matão, Piracicaba 2 e Porto Cubatão); VIII (EMBRAPA); IX (Mandira) e X (Porto do Meio e Santa Maria) (Figura 23).

Para as comunidades tradicionais que cultivam $D$. alata encontrou-se grande diversidade isoenzimática (56\%). As comunidades que cultivam etnovariedades com menor diversidade entre si são Porto do Meio e Santa Maria, que estão próximas geograficamente. Não se verificou para esta espécie uma separação entre os municípios do Vale do Ribeira, como ocorreu para a espécie $D$. trifida. Além disso, a comunidade de Peropava no município de Iguape cultiva materiais com $80 \%$ de similaridade ao material do IAC (comercial) e Porto Cubatão no município de Cananéia também cultiva um material com $65 \%$ de similaridade ao material comercial encontrado no município de Piracicaba, indicando, desta forma, que alguns agricultores cultivavam materiais comerciais em suas roças. 


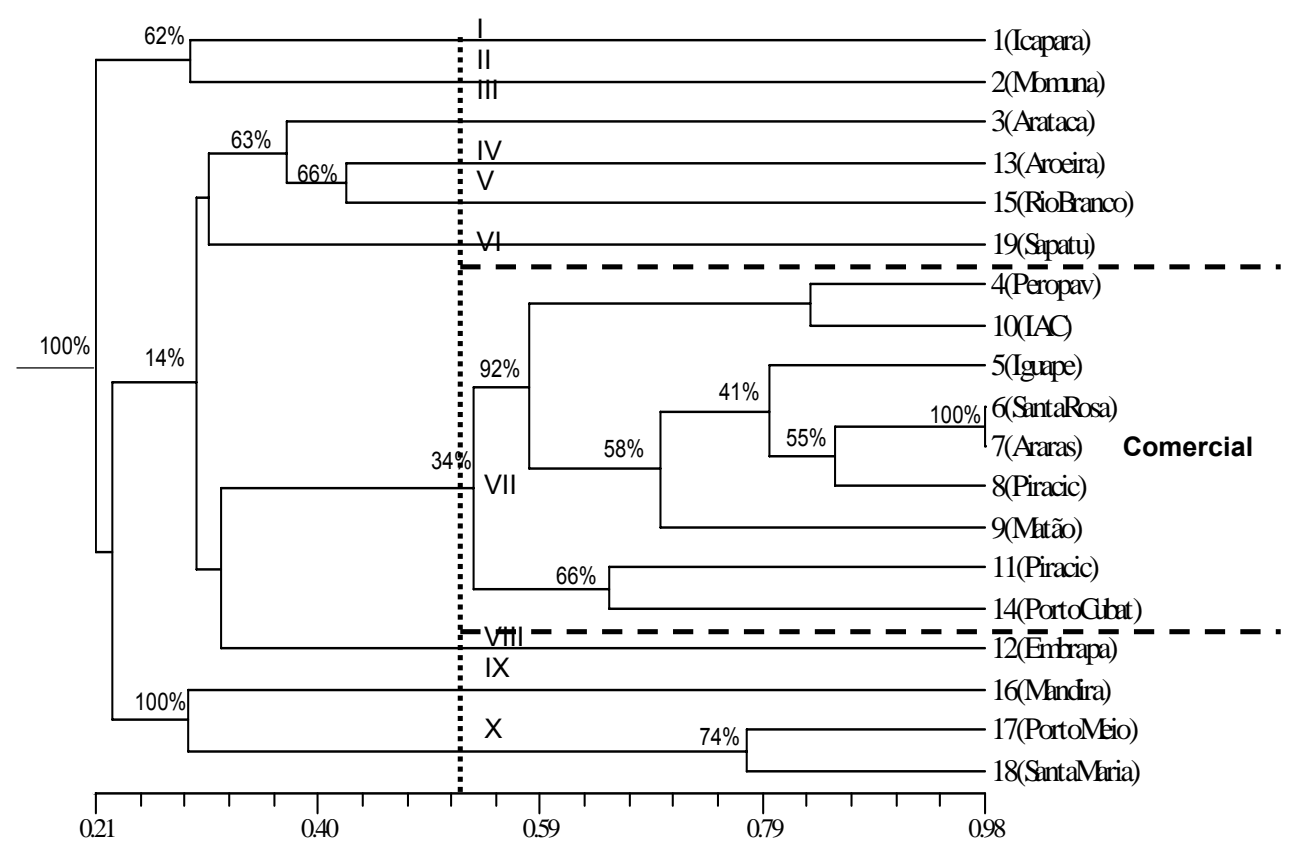

Figura 23 - Análise de agrupamento pelo método aglomerativo UPGMA relativo a 11 comunidades e 8 pontos de coleta de $D$. alata, com base em 71 bandas isoenzimáticas, de acordo com a similaridade do índice de Jaccard. Piracicaba-SP, 2005

Quanto aos materiais comerciais, foram encontrados dois pontos dentro do Estado de São Paulo (Santa Rosa de Viterbo e Araras) que cultivam materiais com 98\% de similaridade. Buscou-se, desta forma, correlacionar as distâncias genéticas e as distâncias geográficas, porém esta foi nula $(r=-0,11)$, mas significativa estatisticamente $(p=0,01)$, sugerindo que não existe correlação entre esses dois parâmetros e que a distribuição das etnovariedades e dos materiais comerciais estão ligados a fatores antrópicos, pois esta espécie é a mais comercializada no Estado de São Paulo.

Com base nos dados de 71 bandas polimórficas utilizando a análise de variância molecular (AMOVA) somente para as etnovariedades cultivadas pelos agricultores tradicionais do Vale do Ribeira, pôde-se verificar que a maior parte da variabilidade isoenzimática encontra-se distribuída dentro de roças dentro de 
comunidades $(53,99 \%)$, ressaltando-se, desta forma, a importância das unidades básicas evolutivas (roças e comunidades) na distribuição da diversidade genética (Tabela 15).

Tabela 15. Resultados da análise de variância molecular (AMOVA) para D. alata. Piracicaba - SP, 2005

\begin{tabular}{cccc}
\hline Fonte de variação & GL & SQ & $\begin{array}{c}\text { Porcentagem da variação } \\
\text { total }\end{array}$ \\
\hline Entre comunidades & 10 & 118,87 & 26,38 \\
Entre roças dentro de comunidades & 2 & 15,00 & 19,63 \\
Dentro de roças dentro de & 3 & 16,50 & 53,99 \\
$\quad \begin{array}{c}\text { comunidades } \\
\text { Total }\end{array}$ & & & \\
\hline
\end{tabular}

Dansi et al. (2005) avaliaram a diversidade de espécies de inhame ( $D$. cayenensis/rotundata) cultivadas pelos agricultores da República de Benin na África em 70 vilas distribuídas em 18 distritos de 13 zonas étnicas. Das 560 etnovariedades apontadas pelos agricultores, somente 343 foram encontradas. A principal causa apontada para a perda de diversidade foi a erosão genética devida a fatores bióticos e econômicos.

Os resultados aqui apresentados mostram que os agricultores tradicionais do Vale do Ribeira mantêm e manejam grande diversidade genética da espécie $D$. alata em suas roças. Quando essas populações forem obrigadas a interromper suas atividades agrícolas, por motivos diversos, poderá ocorrer no futuro problemas como Dansi et al. (2005) encontraram nas roças africanas, ou seja, perda de diversidade genética.

\subsubsection{Análise morfológica}

Rhodes \& Martins (1972) utilizaram 100 caracteres para estudar a variação em 30 cultivares de $D$. alata, concluindo que apenas $28 \%$ dos caracteres utilizados foram úteis para a classificação dos cultivares. Nesta pesquisa utilizaram-se 24 caracteres, 
pois estes foram os mais representativos para as espécies do banco de conservação ex situ da ESALQ/USP.

A análise de agrupamento das 16 etnovariedades e dos 19 materiais comerciais de $D$. alata, obtidas por este método, revelou a formação de vinte e seis grupos (I a XXVI) (Figura 24), seguindo o critério adotado de corte a $70 \%$ de similaridade para os caracteres morfológicos.

O coeficiente de similaridade de Jaccard entre o indivíduo 6 da comunidade de Peropava e do indivíduo 7 do varejão no município de Iguape apresentou coeficiente de similaridade igual a 1 , o que significa que os indivíduos apresentam o mesmo fenótipo morfológico, comprovando-se mais uma vez a proximidade do material de Peropava, com os materiais comerciais.

Pela análise de agrupamento para as etnovariedades e acessos comerciais, verificou-se que não houve separação entre os acessos comerciais e as etnovariedades como ocorreu na avaliação isoenzimática. Nesta análise também não se verifica a distinção das etnovariedades por unidades culturais como ocorreu na espécie $D$. trifida.

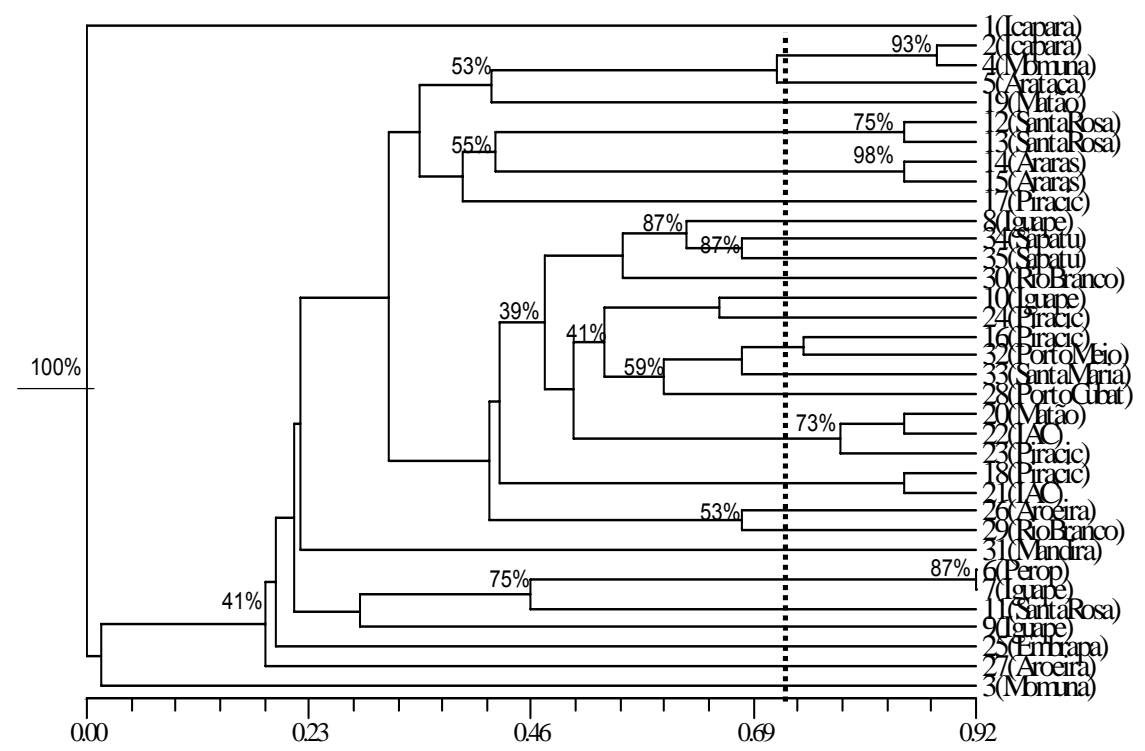

Figura 24 - Análise de agrupamento pelo método aglomerativo UPGMA relativo a 16 etnovariedades e 19 acessos comerciais de $D$. alata, com base em 24 caracteres morfológicos, de acordo com a similaridade do índice de Jaccard. Piracicaba-SP, 2005 
Retirou-se também dos dendrogramas as amplitudes de similaridades para as etnovariedades. A amplitude de similaridade variou de 0,92 a 0,00 indicando, desta forma, que as etnovariedades possuem uma grande variação (92\%) para os caracteres morfológicos.

A análise de agrupamento entre as comunidades e os locais de coleta para espécie D. alata, revelou a formação de sete grupos (I a VII), nos quais as comunidades e os locais de coleta foram distribuídos da seguinte forma: I (Icapara); II (Momuna, Peropava e Iguape); III (Arataca, Santa Rosa, Araras, Piracicaba 1, Matão, IAC, Piracicaba 2, EMBRAPA e Aroeira); IV (Porto Cubatão); V (Rio Branco); VI (Mandira e Porto do Meio) e VII (Santa Maria e Sapatu) (Figura 25).

As amplitudes de similaridade de Jaccard variaram para esta análise de agrupamento de 1,00 a 0,51 indicando, desta forma, que as comunidades variaram em $49 \%$, ou seja, existe grande diversidade entre as unidades culturais e os locais de coleta quanto a morfologia.

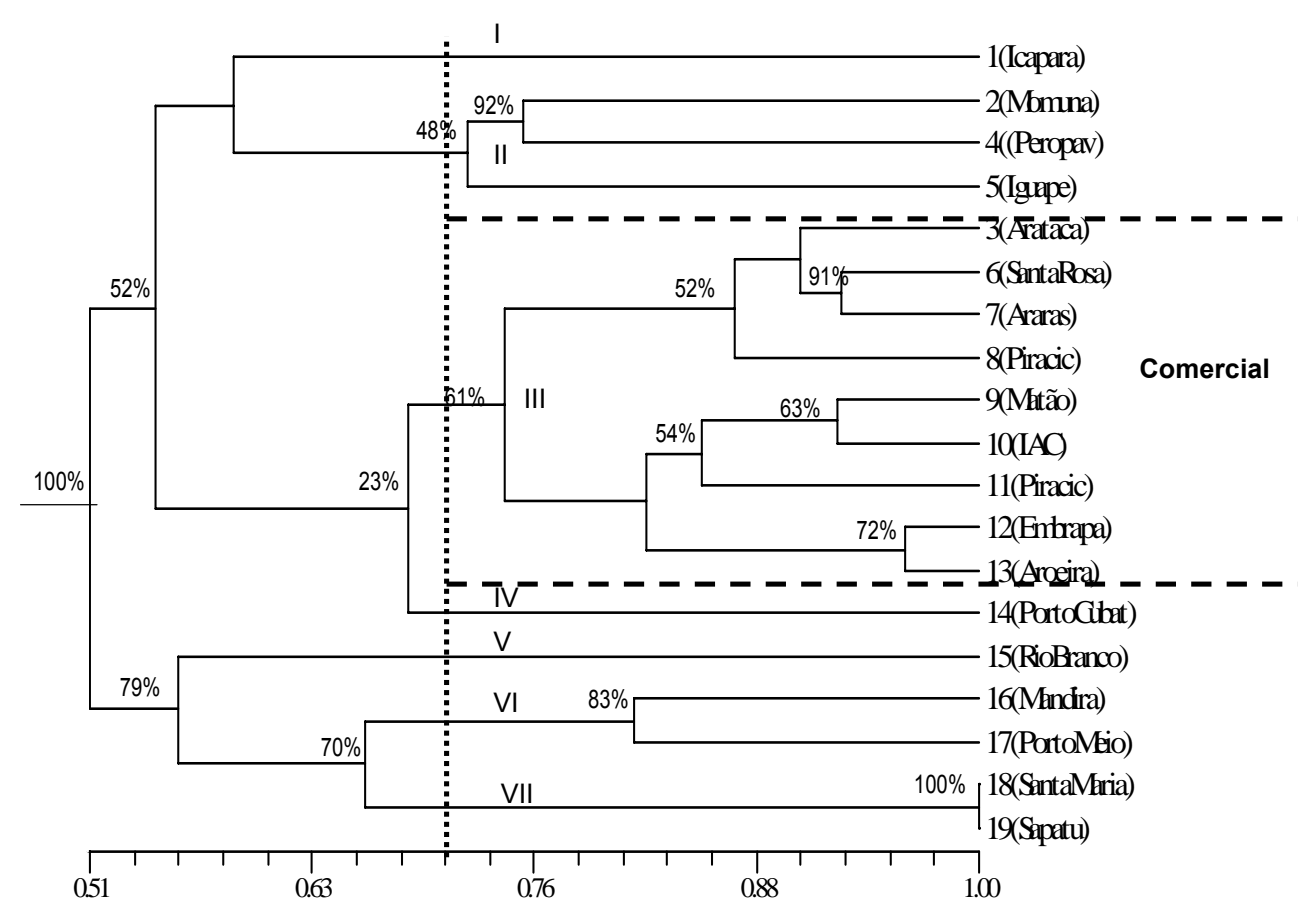

Figura 25 - Análise de agrupamento pelo método aglomerativo UPGMA relativo a 11 comunidades e 8 pontos de coleta de $D$. alata, com base em 24 caracteres morfológicos, de acordo com a similaridade do índice de Jaccard. Piracicaba-SP, 2005 
Os grupos I e II reúnem as etnovariedades coletadas nas comunidades do município de Iguape, já o grupo III concentra os pontos de coleta de materiais comerciais e uma comunidade próxima ao centro comercial de Cananéia (Aroeira) e uma comunidade (Arataca) que se dedica à produção de inhames para o comércio nas feiras e varejões de Iguape. Encontraram-se também comunidades que cultivam etnovariedades com $100 \%$ de similaridade quanto aos caracteres morfológicos em Santa Maria (Cananéia) e Sapatu (Eldorado Paulista) no grupo VII.

A correlação entre a morfologia e a distância geográfica foi nula $(r=0,03)$, sugerindo que a diversidade morfológica não está estruturada no espaço.

Com base nos marcadores morfológicos (24 caracteres) utilizando a análise de variância molecular (AMOVA), verificou-se que $70,11 \%$ da variabilidade encontra-se dentro de roças dentro de comunidades (Tabela 16), indicando a ação dos agricultores tradicionais na seleção dos materiais dentro das unidades evolutivas (roças).

Tabela 16. Resultados da análise de variância molecular (AMOVA) para os dados morfológicos de D. alata. Piracicaba - SP, 2005

\begin{tabular}{cccc}
\hline Fonte de variação & GL & SQ & $\begin{array}{c}\text { Porcentagem da variação } \\
\text { total }\end{array}$ \\
\hline Entre comunidades & 10 & 70,31 & 0,00 \\
Entre roças dentro de comunidades & 2 & 15,00 & 29,89 \\
Dentro de roças dentro de & 3 & 14,00 & 70,11 \\
comunidades & & & \\
Total & 15 & 99,31 & \\
\hline
\end{tabular}

A diversidade morfológica está distribuida em grande parte dentro nas unidades evolutivas básicas e culturais (roças e comunidades). Este resultado difere das duas espécies encontradas nas roças dos agricultores tradicionais do Vale do Ribeira $(D$. trifida e $D$. bulbifera) avaliadas pelos marcadores morfológicos e vem ao encontro dos resultados obtidos por Peroni (1998) e Sambatti (1998) com a cultura da mandioca nas roças autóctones do litoral paulista. Sambatti (1998) demonstrou em sua pesquisa que a maior parte da variabilidade para a cultura da mandioca está distribuída dentro das roças. Já Peroni (1998) cita que a seleção perceptiva dos agricultores como outros fatores microevolutivos facilitados pelo manejo das roças agem no aumento da 
variabilidade das plantas. Neste caso, cita-se o grande número de nomes populares ("cará guaçu", "cará aipim", "cará branco", "cará são João", "cará São João branco", "cará São João roxo", "cará bolo", "cará coco", "cará roxo" e "cará branco"), utilizados pelos agricultores tradicionais, podendo encobrindo níveis de diversidade não reconhecidos por esses. Por exemplo, o nome cará guaçu foi atribuído as etnovariedades número 1 (grupo I) e $\mathrm{n}^{\circ} 5$ (grupo III), distantes geneticamente, bem como o nome cará branco ao $n^{\circ} 3$ do grupo XXVI e $n^{\circ} 35$, grupo $X$ (Figura 24).

\subsubsection{Correlação entre as estimativas isoenzimáticas e morfológicas}

Para esta espécie o coeficiente entre as distâncias genéticas isoenzimáticas e morfológicas foi positivo $(r=0,27)$, mas não significativo $(p=0,99)$, sugerindo que não existe correlação entre esses dois parâmetros, desta forma, os agricultores tradicionais deparam-se com algumas variações morfológicas que não refletem as diferenças isoenzimáticas. A ausência de correlação entre as distâncias genéticas moleculares e morfológicas é devido a fraca cobertura genômica conseguida com os locos isoenzimáticos, pois poucos locos são vasculhados geralmente, segundo Vencovsky ${ }^{2}$. Faleiro et al. (2005) relataram em seu trabalho que mesmo para a distância genética entre marcadores moleculares (RAPD e microssatélites) no estudo da diversidade genética do cacaueiro, a correlação foi baixa e não significativa estatisticamente. Já Telles et al. (2001) demonstraram na sua pesquisa com cagaiteira (Eugenia dysenterica) um coeficiente de correlação entre as matrizes de distâncias genéticas (isoenzimas e morfologia) positivo $(r=0,289)$ e estatisticamente significativo a $(p<0,05)$ para populações naturais.

\footnotetext{
${ }^{2}$ Vencovsky, R. (Departamento de Genética da Escola Superior de Agricultura "Luiz de Queiroz"). Comunicação pessoal.
} 


\subsection{Conclusões}

Os marcadores isoenzimáticos e morfológicos revelaram a existência de grande diversidade genética entre as etnovariedades cultivadas pelos agricultores tradicionais. Além disso, os marcadores isoenzimáticos separaram os materiais comerciais que apresentam maior similaridade entre si quando comparados com as etnovariedades sendo, portanto, mais informativos que os morfológicos. Os nomes populares "cará guaçu”, "cará aipim”, “cará branco", "cará são João”, “cará São João branco”, "cará São João roxo", "cará bolo", "cará coco", "cará roxo" e "cará branco", empregados pelos agricultores tradicionais podem encobrir níveis de diversidade não reconhecidos por esses.

A maior parte da diversidade em $D$. alata, mesmo que não estruturada no espaço, encontra-se dentro de roças dos agricultores tradicionais do Vale do Ribeira. Isto se deve à grande variabilidade encontrada para esta espécie. 


\section{DIVERSIDADE ISOENZIMÁTICA E MORFOLÓGICA DE Dioscorea cayenensis EM ROÇAS DE AGRICULTURA TRADICIONAL DO VALE DO RIBEIRA - SP}

\section{Resumo}

Os inhames (Dioscorea spp.) são cultivados em regiões quentes, sendo que aproximadamente $95 \%$ da produção mundial está concentrada no continente africano. Das 600 espécies de inhame conhecidas, apenas seis são utilizadas como alimento e a espécie $D$. cayenensis é uma das mais cultivadas. No Brasil, esta espécie é cultivada comercialmente no Nordeste e, na região Sudeste, é cultivada por agricultores tradicionais do Vale do Ribeira. O presente estudo teve como objetivo avaliar a diversidade genética de 21 etnovariedades de $D$. cayenensis e dois acessos de $D$. rotundata, por meio de marcadores isoenzimáticos e morfológicos, verificando como esta se distribui nos diferentes níveis de organização, como roças e comunidades do Vale do Ribeira. As etnovariedades e os dois acessos de D. rotundata foram caracterizados por meio de marcadores isoenzimáticos utilizando géis de poliacrilamida (seis sistemas enzimáticos) e amido (um sistema) e por marcadores morfológicos (24 caracteres). Devido à natureza poliplóide do inhame os materiais foram genotipados gerando dados binários. Os dados morfológicos também foram analisados por meio de notas transformados em uma matriz binária. Para ambos os dados foi calculado o índice de similaridade de Jaccard entre pares de indivíduos. A partir dos índices médios de similaridade de Jaccard para variedades, roças e comunidades foram feitos dendrogramas pelo critério de agrupamento UPGMA. Pelas análises de agrupamento houve a separação entre os dois acessos de $D$. rotundata e as etnovariedades coletadas nas roças tradicionais do Vale do Ribeira. Outro parâmetro analisado foi a correlação entre as matrizes de distância genética e geográfica, verificando-se um valor negativo $(r=-0,13)$ para isoenzimas, sugerindo que não existe correlação entre esses dois parâmetros. Foi também realizada a análise de variância molecular 
(AMOVA) e pôde-se verificar que a variabilidade isoenzimática encontrava-se entre roças dentro de comunidades $(42,54 \%)$ e entre comunidades $(40,26 \%)$. Pela análise de agrupamento para os descritores morfológicos, verificou-se que não houve uma separação das espécies do complexo $D$. cayenensis/D. rotundata como ocorreu na avaliação isoenzimática. A correlação entre as distâncias morfológicas e geográficas também indicou que a diversidade não estava estruturada no espaço $(r=0,05)$. De acordo com a AMOVA, a maior parte da variabilidade morfológica encontrava-se entre roças dentro de comunidades $(44,81 \%)$. Correlacionando-se as estimativas isoenzimáticas e morfológicas chegou-se a uma correlação negativa $(r=-0,05)$. As informações obtidas com a diversidade genética (isoenzimática e morfológica) revelaram que os agricultores tradicionais mantêm e manejam grande variabilidade de D. cayenensis em suas comunidades, portanto, ambos os marcadores foram adequados para o estudo da diversidade do inhame. Porém, não houve concordância entre o sistema de taxonomia "folk" e os marcadores genéticos. 
ISOENZYMATIC AND MORPHOLOGICAL DIVERSITY OF Dioscorea cayenensis IN SWIDDENS OF TRADITIONAL AGRICULTURE OF THE RIBEIRA RIVER VALLEYSP

\section{Summary}

Yams (Dioscorea spp.) are cultivated in hot tropical regions, with 95\% of its world production concentrated in the African continent. Of the 600 known yam species, only six are utilized as food and $D$. cayenensis is one of the most cultivated species. In Brazil, this species is commercially cultivated in the northeast region and, in the southeast region, is cultivated by traditional agriculturists of the Ribeira River Valley. This study had the aim of evaluating the genetic diversity of 21 ethnovarieties of $D$. cayenensis and two $D$. rotundata accessions, using isozymic and morphological markers, verifying how this diversity is distributed in the different levels of organization, such as swiddens and communities of the Ribeira River Valley. The isozyme analyses were conducted with polyacrylamide (six enzyme systems) and starch gels (one enzyme system) and the morphological analyses were carried out with 24 characters. Due to the polyploid nature of yams the material was scored as binary data. The morphological data were also transformed into a binary matrix. Cluster analyses were conducted for ethnovarieties, swiddens and communities using the Jaccard similarity index among pairs of individuals and the UPGMA clustering method. The cluster analyses for the isozymic data separated the two $D$. rotundata accessions from $D$. cayenensis ethnovarieties collected in the traditional swiddens of the Ribeira River Valley. Another parameter evaluated was the correlation between the genetic and geographic distances matrices, where a negative value was obtained $(r=-0.13)$ for the isozyme data, suggesting the non existence of correlation between these two parameters. The molecular analysis of variance (AMOVA) was also conducted, indicating that most of the isozymic variability was concentrated among swiddens within communities (42.54\%) and within communities (40.26\%). The cluster analyses for the morphological data indicated the presence of two groups (Iguape and Cananéia), which showed the great influence of the cultural units on the morphological characters. The correlation between the geographic and the genetic distances also indicated that the morphological diversity was not structured in space $(r=0.17)$. The cluster analyses for the morphological characters did not show a clear separation between the species of 
the $D$. cayenensis/D. rotundata complex, as occurred with the isozyme analyses. The correlation between the morphological and geographical distances also indicated that the morphological diversity was not structured in space. According to the AMOVA, most of the morphological variability was concentrated between swiddens within communities (44.81\%). When correlating the isozymic and the morphological markers, a negative correlation ( $r=-0.05$ ) was found. The information obtained with the genetic diversity (isozymic and morphological) showed that the traditional agriculturists maintain and manage great variability of $D$. cayenensis in their communities, therefore, both markers were adequate for the study of yam diversity. However, there was no agreement between the folk taxonomy and the genetic markers. 


\subsection{Introdução}

Os inhames (Dioscorea spp.) são cultivados em regiões quentes, sendo que aproximadamente $95 \%$ da produção mundial está concentrada no continente africano. As demais regiões produtoras situam-se na Ásia e América. Das 600 espécies de inhame conhecidas, apenas seis são utilizadas como alimento e a espécie Dioscorea cayenensis é uma das mais cultivadas (Coelho, 2002).

A produção mundial de inhame no ano de 2000 foi de 37,5 milhões de toneladas, sendo que $90 \%$ está concentrada nos países da África como Cameroon, Nigéria, República de Benin, Togo e Gana (IITA, 2002).

A história da agricultura do continente americano sofreu profunda mudança entre os séculos 16 e 18 devido a trocas de saberes entre as sociedades. Nesta troca de conhecimentos e espécies o continente africano contribuiu para o continente americano com o inhame (D. cayenensis), quiabo (Abelmoschus esculentus), milheto (Pennisetum glaucum), sorgo (Sorghum bicolor), entre outras espécies (Carney \& Marin, 2004). No Brasil, os escravos vindos da África detinham o conhecimento sobre o cultivo do inhame, pois se alimentavam deste tubérculo em suas regiões de origem. Assim, esta espécie foi introduzida na América como um cultivo de subsistência e por motivos culturais.

Os principais Estados brasileiros produtores de inhame situam-se na região Nordeste, onde predomina o cultivo da espécie comestível $D$. cayenensis (cará da costa, cará de espinho ou cará d' angola) (Coelho, 2002). Já na região Sudeste do Brasil encontra-se agricultores tradicionais do Vale do Ribeira cultivando esta espécie em roças de toco ou corte e queima. Esta espécie é cultivada nas roças abandonadas, ou seja, em pousio onde a vegetação da Mata Atlântica encontra-se em estágio de regeneração.

Os agricultores tradicionais costumam utilizar as roças em pousio como "banco de germoplasma", para a abertura de novas roças e local de caça, pois os animais são atraídos pelas espécies e variedades de plantas abandonadas como os tubérculos de mandioca, cará, ramas de batata-doce, bananas, etc. Desta forma, o agricultor tradicional favorece a amplificação da diversidade de espécies através de mecanismos como o arranjamento espacial das plantas, introdução de novas variedades, fonte de alimento para animais e o sistema de agricultura (corte e queima). A grande maioria 
das roças tradicionais do Vale do Ribeira destina-se à produção de alimentos para subsistência dos agricultores, sendo constante a prática do policultivo.

Para estudar a variabilidade genética das etnovariedades cultivadas pelos agricultores tradicionais do Vale do Ribeira, alguns trabalhos foram desenvolvidos utilizando a morfologia e análise isoenzimática da mandioca (Manihot esculenta Crantz) destacando-se os de Cury (1993; 1998), Faraldo (1994; 1999), Peroni (1998), Sambatti (1998) e Silva (2000) que explicitavam a dinâmica evolutiva da cultura nas roças de toco desta região. Porém, existem mais espécies de propagação vegetativa, como o inhame e a batata-doce, que também são manejadas pelos agricultores tradicionais no vale do rio Ribeira de Iguape que ainda não foram estudadas.

Internacionalmente, alguns trabalhos foram produzidos com a caracterização isoenzimática e morfológica de acessos inhame do complexo $D$. cayenensis-rotundata, como Hamon \& Toure (1990), Zoundjihekpon et al. (1994) e Mignouna et al. (2002).

Com o objetivo de estimar a diversidade genética das etnovariedades de $D$. cayenensis cultivadas pelos agricultores tradicionais do Vale do Ribeira, SP, formados pela mescla etno-cultural de indígenas, portugueses (colonizadores) e escravos africanos (quilombolas) que possuem sua forma de vida baseada na agricultura itinerante, pesca, extrativismo vegetal e artesanato, foram avaliados marcadores isoenzimáticos e morfológicos, verificando de que forma esta diversidade se distribui nos diferentes níveis hierárquicos: dentro de roças e quintais (unidade básica evolutiva), entre roças e quintais dentro de comunidades (unidade cultural) e entre comunidades tradicionais do Vale do Ribeira. Verificou-se também, a existência de correlação entre as distâncias geográficas e genéticas (isoenzima e morfologia) e entre as distâncias genéticas de ambos os marcadores. Além disso, buscou-se comparar as etnovariedades com os dois acessos de $D$. rotundata, pois a chave de identificação das espécies de inhame do IPGRI/IITA (1997) gerava dúvidas durante a identificação da espécie coletada nas roças de agricultura tradicional do Vale do Ribeira. 


\subsection{Material e Métodos}

Coletou-se 21 etnovariedades de $D$. cayenensis junto as comunidades que praticam a agricultura tradicional nos municípios de Cananéia $\left(25^{\circ} 00^{\prime} \mathrm{S}\right.$ e $\left.47^{\circ} 55^{\prime} \mathrm{W}\right)$,

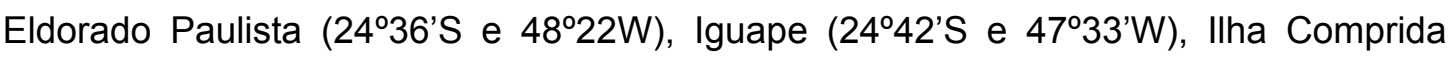

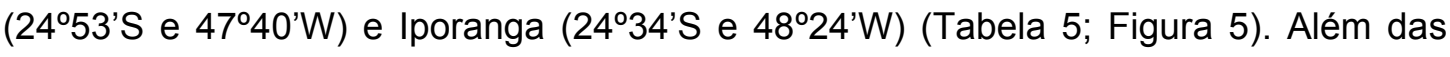
etnovariedades do Vale do Ribeira foram avaliados também dois acessos da espécie D. rotundata (acessos 22 e 23), provenientes da Embrapa Mandioca e Fruticultura

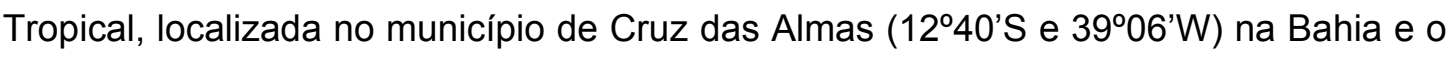
outro acesso é proveniente de um supermercado da cidade de Piracicaba - SP

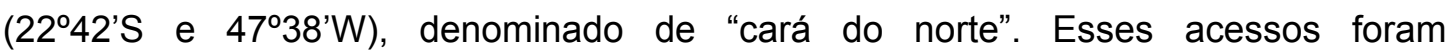
introduzidos na coleção visando comparar as duas espécies, já que fazem parte de um complexo cuja identificação morfológica é complicada.

Coletou-se um tubérculo de cada roça, com exceção dos agricultores 4, 8 e 14 das comunidades de Momuna (Iguape) São Paulo Bagre (Cananéia) e Pedrihas (Ilha Comprida), respectivamente, onde foram coletados dois tubérculos nas duas primeiras roças e três na última. Desta forma, o número médio de etnovariedades coletadas por roça foi de 1,2. Esses materiais foram trazidos para o Departamento de Genética da Escola Superior de Agricultura "Luiz de Queiroz" da Universidade de São Paulo, em Piracicaba e plantados em vasos e mantidos em casa-de-vegetação em uma primeira etapa de brotação e quarentena. Dois meses após as mudas foram transplantadas para um campo experimental em leiras preparadas na forma de camalhões, sem repetição. O espaçamento entre fileiras e entre plantas foi de 1,50 m. Para a condução das plantas utilizaram-se varas de bambu de aproximadamente $1,80 \mathrm{~m}$, visando orientar o crescimento das plantas. Foi originado, desta forma, o banco de germoplasma de conservação ex situ de $D$. cayenensis e $D$. rotundata do Laboratório de Ecologia Evolutiva e Genética Aplicada (LEEGA).

Observou-se também o florescimento e a frutificação desta espécie, pois alguns agricultores tradicionais relataram durante a doação dos materiais a presença de flores pequenas e brancas no "cará de espinho" ou "cará d'angola", nomes populares atribuídos à $D$. cayenensis no Vale do Ribeira.

Para esta pesquisa convencionou-se que as unidades básicas evolutivas (roça e quintal) serão analisadas apenas como "roça". 


\subsubsection{Análise isoenzimática}

A caracterização e avaliação da diversidade da espécie $D$. cayenensis, cultivada pelos agricultores tradicionais e os acessos de $D$. rotundata foram avaliados através da técnica de eletroforese de isoenzimas (Soltis \& Soltis, 1990).

O protocolo para extração e visualização das formas moleculares de uma mesma enzima foi adaptado e utilizado na avaliação genética com base nos padrões isoenzimáticos dos acessos estudados conforme os itens 4.2.1.1, 4.2.1.2 e 4.2.1.3 (Figuras 12; 13), utilizando géis de amido e poliacrilamida.

Testaram-se 18 sistemas isoenzimáticos (Tabela 7), sendo que os principais critérios para a escolha dos sistemas que seriam utilizados foram a resolução, presença de polimorfismo, repetibilidade e interpretabilidade. Foram selecionados os seguintes sistemas: MDH para o gel de amido e os sistemas PGM, ${ }_{6} P D H, G P I, S O D$, SKDH e ATT para poliacrilamida.

\subsubsection{Análise morfológica}

As avaliações morfológicas foram realizadas em plantas individuais no campo experimental do Departamento de Genética da ESALQ/USP, onde os acessos foram multiplicados, sem repetições.

Utilizou-se na caracterização morfológica os descritores preconizados pelo International Plant Genetic Resources Institute (IPGRI) e International Institute of Tropical Agriculture (IITA), em Ibadan, Nigéria, descritos com suas respectivas escalas de notas em IPGRI/IITA (1997). Além dos descritores, utilizou-se também a chave de identificação de espécies de Dioscorea spp. (IPGRI/IITA, 1997) para separar os acessos de $D$. cayenensis e $D$. rotundata, consultando-se também Martin \& Rhodes (1978).

Para a caracterização das 21 etnovariedades cultivadas pelos agricultores do Vale do Ribeira e dos dois acessos de $D$. rotundata foram avaliados 24 descritores morfológicos, associados a caracteres de folha, caule, tubérculos e florescimento (Tabelas 8, 9 e 10).

As avaliações morfológicas foram realizadas em duas etapas, sendo a primeira aos seis meses após o transplantio dos acessos no campo, pois nesta época havia 
disponibilidade suficiente de tecidos (folhas jovens, adultas e ramos) e a segunda ocorreu durante a colheita quando os tubérculos foram avaliados.

As observações foram baseadas na média fenotípica de 10 medições dos descritores quantitativos para as folhas, caules e tubérculos de cada planta do banco de germoplasma. Já os dados qualitativos foram avaliados por meio de notas.

A partir das avaliações construiu-se uma tabela descritiva de todos os caracteres morfológicos analisados para as etnovariedades permitindo desta forma, a análise estatística.

\subsubsection{Análise estatística}

Os padrões de bandas do complexo $D$. cayenensis/D. rotundata, devido à natureza poliplóide, apresentaram alta complexidade, não sendo possível a avaliação do material em termos de locos e alelos ou por freqüências alélicas e genotípicas. Os materiais foram, portanto, genotipados como dados binários, gerando uma matriz binária. Os dados morfológicos também foram analisados por meio de notas, transformados em dados binários. Para as análises isoenzimáticas foram calculados os números de bandas por sistema, número total de bandas e porcentagem de bandas polimórficas.

Para ambos os dados foram calculados o índice de similaridade de Jaccard entre pares de indivíduos com base nas matrizes binárias dos dados isoenzimáticos e morfológicos. A estimação da variabilidade foi visualizada a partir dos índices médios de similaridade para variedades, roças e comunidades e dos dendrogramas baseados no método de agrupamento UPGMA (Rohlf, 1992).

O critério para a formação dos grupos foi adotar o limite mínimo de $50 \%$ de similaridade para os dados isoenzimáticos e $70 \%$ para os dados morfológicos entre as variedades, roças e comunidades para que fossem incluídas no mesmo grupo.

A avaliação da estabilidade dos agrupamentos dos dendrogramas foi baseada em estimativas de dissimilaridades genéticas através do procedimento de reamostragens com 1.000 bootstraps empregando o programa BOOD versão $2.0 \mathrm{e}$ BOOD-P (Coelho, 2001; 2003). Neste programa os valores superiores a $50 \%$ nos 
"nós", que unem os grupos, indicam que as distâncias genéticas entre as unidades biológicas de um mesmo grupo são estáveis.

Com o objetivo de simplificar a análise, foi realizada uma comparação apenas entre as roças e outra apenas para comunidades. As roças foram analisadas através da média da matriz de similaridade de Jaccard das etnovariedades dando origem a uma matriz, utilizada para estudar a variabilidade das roças a partir dos agrupamentos formados. Da mesma forma, as comunidades foram analisadas através da média da matriz de similaridade gerada para roças.

Foi realizada uma análise de variância molecular (AMOVA) somente para os materiais coletados nas roças dos agricultores tradicionais do Vale do Ribeira. Para tanto, utilizaram-se as distâncias ao quadrado, conforme descrito por Excoffier et al. (1992) com o auxílio do programa Arlequin (Schneider et al., 2004).

Com a finalidade de analisar os padrões de variação espacial, buscou-se correlacionar a diversidade genética (isoenzimática e morfológica) com a estrutura espacial, para tentar entender a dinâmica evolutiva da cultura dentro dos sistemas agrícolas tradicionais do Vale do Ribeira, pois as espécies sofrem pressão de forças evolutivas que podem atuar conjunta ou isoladamente em diferentes intensidades determinando, desta forma, a existência ou não de um paralelismo entre as distâncias genéticas e geográficas. O coeficiente utilizado foi a correlação de Pearson ( $r$ ) através das matrizes de distâncias genéticas calculadas pelo índice de similaridade de Jaccard e as distâncias geográficas entre as espécies. A distância geográfica foi estimada a partir das coordenadas originais das roças e quintais utilizando o programa TrackMaker versão 12.3 (Ferreira Junior, 2004).

A correlação de Pearson ( $r$ ) também foi utilizada para verificar a associação entre a diversidade molecular (dados isoenzimáticos) e a diversidade morfológica.

O nível de significância das correlações foi testado pelo método estatístico de Mantel (Z), utilizando 1.000 permutações aleatórias (Zucchi, 2002). 


\subsection{Resultados e Discussão}

\subsubsection{Avaliação isoenzimática}

O sistema SOD apresentou o maior número de bandas (13) seguido pelo SKDH com 12, GOT, G 6 PDH e PGI com 9, MDH com 7 e PGM com 6, num total de 65 bandas para todos os sistemas. Observou-se $100 \%$ de bandas polimórficas. A combinação das diferentes bandas isoenzimáticas de todas as enzimas avaliadas nos dois tipos de géis (amido e poliacrilamida) possibilitou ainda a discriminação de 17 etnovariedades das 21 analisadas, além dos dois acessos de $D$. rotundata.

Esse polimorfismo detectado permitiu a discriminação da variabilidade genética entre as etnovariedades de $D$. cayenensis coletadas nas roças dos agricultores tradicionais e os acessos de $D$. rotundata. Dansi et al. (2000) também utilizaram a técnica de eletroforese de isoenzimas para analisar 467 acessos do complexo D. cayenensis/rotundata onde identificou 227 cultivares.

A análise de agrupamento relativa às 21 etnovariedades de $D$. cayenensis e aos dois acessos de $D$. rotundata, revelou a formação de dez grupos (I a X), nos quais as etnovariedades foram distribuídas da seguinte forma: I (1, 2, 3, 4, 5, 7, 15, 16 e 18); II (9 e 10); III (6); IV (8); V (13, 19, 20 e 21); VI (12 e 14); VII (13) e VIII (11). Os dois acessos de $D$. rotundata foram distribuídos nos grupos IX (22) e X (23) (Figura 26).

O coeficiente de similaridade de Jaccard entre os indivíduos 4 e 5 da roça 4 da comunidade de Momuna no município de Iguape e os indivíduos 15 (cará guaçu) e 16 (cará de espinho) das roças 13 e 14 das comunidades de Santa Maria em Cananéia e Pedrinhas no município de Ilha Comprida apresentaram coeficiente de similaridade igual a 1. Portanto, na roça 4 da comunidade de Momuna observaram-se dois acessos que representam duplicatas, pois apresentaram o mesmo fenótipo isoenzimático dentro da roça, embora o agricultor os tenha identificado como materiais diferentes, apesar de apresentarem o mesmo nome comum (Tabela 5).

Nas roças 13 e 14 das comunidades de Santa Maria e Pedrinhas, respectivamente, observa-se que os acessos 15 e 16 representam duplicatas, pois apresentam o mesmo fenótipo isoenzimático. Embora os agricultores os tenham identificado com nome comum diferente, esses apresentam a mesma origem, pois 0 
agricultor de Pedrinhas é amigo do agricultor de Santa Maria e o primeiro buscou as mudas de $D$. cayenensis com o amigo em Santa Maria, segundo informações do próprio agricultor.

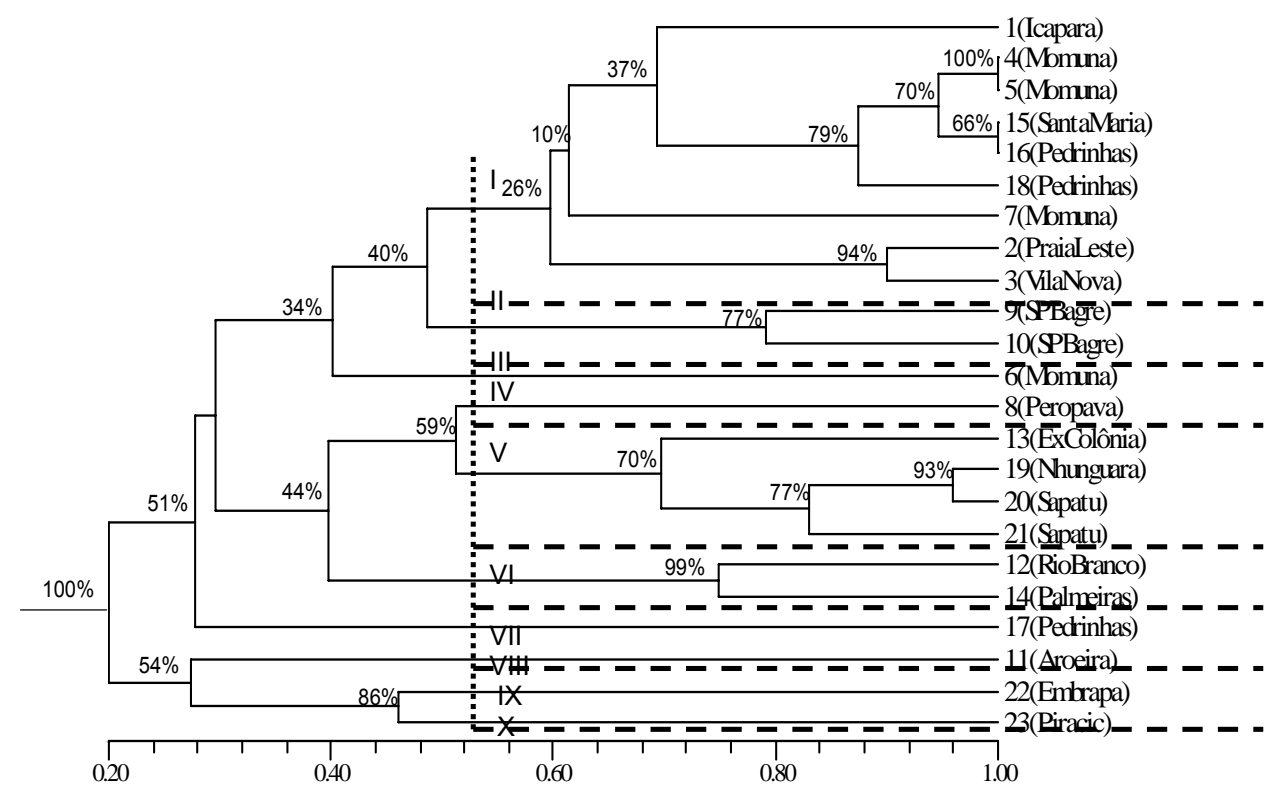

Figura 26 - Análise de agrupamento pelo método aglomerativo UPGMA relativo a 21 etnovariedades de $D$. cayenensis e dois acessos de $D$. rotundata, com base em 65 bandas isoenzimáticas, de acordo com a similaridade do índice de Jaccard. Piracicaba-SP, 2005

Pelas análises de agrupamento das etnovariedades, observa-se cinco grupos (II, V, VI, IX e X) que merecem comentários.

O grupo II é formado por duas etnovariedades que eram cultivadas em quintais por mãe e filho na comunidade de São Paulo Bagre. Esta comunidade está localizada na Área de Proteção Ambiental (APA) do município de Cananéia onde os agricultores são proibidos por lei de abrirem roças; desta forma, a espécie está sendo cultivada nos quintais das casas.

$\mathrm{O}$ grupo $\mathrm{V}$ é formado por quatro etnovariedades das comunidades de ExColônia (Cananéia), Nhunguara (Iporanga) e Sapatu (Eldorado). Os acessos das duas 
últimas comunidades são semelhantes em aproximadamente $85 \%$, o que provavelmente se deve à proximidade entre essas comunidades.

O grupo VI abriga as etnovariedades das comunidades de Rio Branco e Palmeiras no município de Cananéia, onde os agricultores declararam trocar materiais entre si. Além disso, as comunidades são próximas geograficamente.

Já os grupos IX e X são formados pelos dois acessos de $D$. rotundata de diferentes regiões do Brasil, mas que apresentam $45 \%$ de similaridade, mostrando, desta forma, que os indivíduos apresentam certa similaridade genética, mesmo sendo cultivados em Estados diferentes do Brasil.

O coeficiente de Jaccard variou de 0,20 a 1,00 de similaridade, indicando que as etnovariedades possuem uma variação de similaridade de $80 \%$, ou seja, existe grande diversidade entre os acessos de $D$. cayenensis coletados nas roças dos agricultores tradicionais do Vale do Ribeira.

Entre as comunidades (unidade evolutiva cultural) que cultivam D. cayenensis, observa-se a formação de sete grupos (I a VII), nos quais as comunidades foram distribuídas da seguinte forma: I (Icapara, Praia do Leste, Vila Nova, Momuna, Santa Maria e Pedrinhas); II (São Paulo Bagre); III (Peropava, Ex-Colônia, Nhunguara e Sapatu); IV (Rio Branco e Palmeiras); V (Aroeira); VI (Embrapa) e VII (Piracicaba) (Figura 27). Também se verifica a formação dos mesmos grupos que separam as etnovariedades e comunidades (grupos I, II, III, IV e V), além dos dois acessos de $D$. rotundata (grupos VI e VII).

Para as comunidades que cultivam $D$. cayenensis foram encontradas duas unidades culturais (Praia do Leste e Vila Nova) que apresentam 90\% de similaridade nos materiais cultivados, o que se deve à proximidade geográfica entre essas comunidades.

A correlação entre as distâncias genéticas e geográficas foi nula $(r=-0,13)$ e não significativa estatisticamente. A provável razão é a existência de trocas aletórias de materiais entre as unidades culturais e mesmo o acréscimo de variabilidade genética via reprodução sexual. Essas plantas são também consumidas por animais nas roças em pousio. 


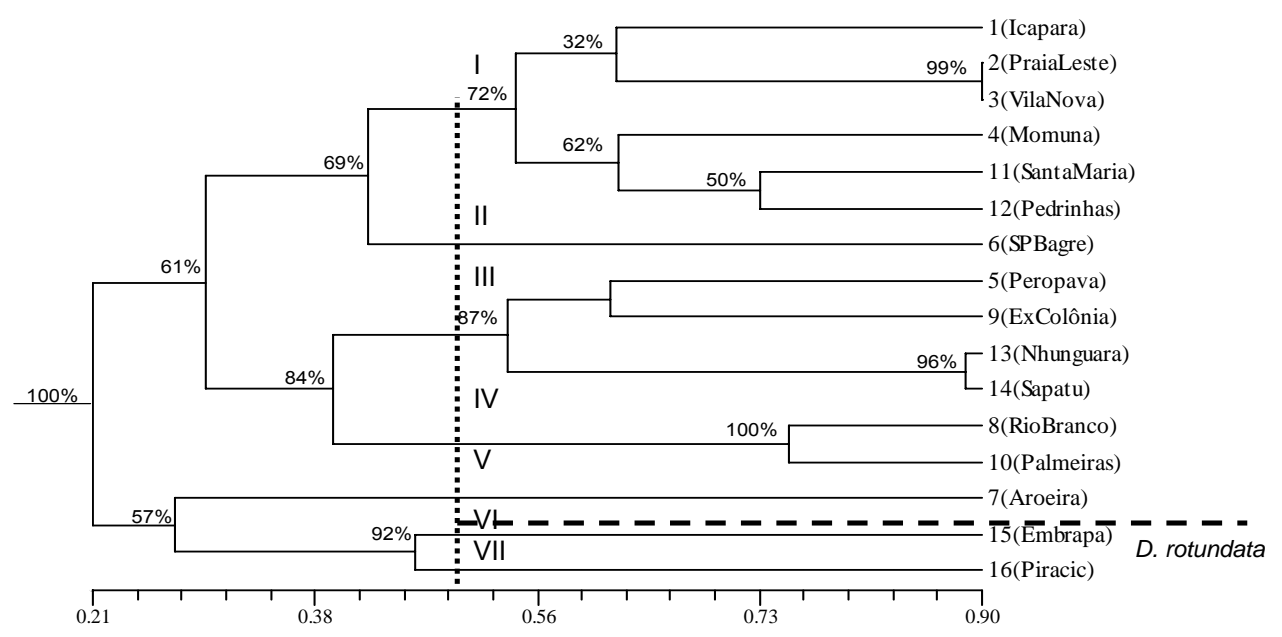

Figura 27 - Análise de agrupamento pelo método aglomerativo UPGMA relativo a 14 comunidades que cultivam a espécie $D$. cayenensis e dois locais que cultivam a espécie $D$. rotundata, com base em 65 bandas isoenzimáticas, de acordo com a similaridade do índice de Jaccard. Piracicaba-SP, 2005

Com base nos dados de 65 bandas polimórficas utilizando a análise de variância molecular (AMOVA) verificou-se que a variabilidade encontra-se distribuída em equilíbrio entre roças dentro das comunidades (42,54\%), e entre as comunidades $(40,26 \%)$, ressaltando, desta forma, a importância das unidades evolutivas (roças e comunidades) na distribuição da diversidade genética (Tabela 17).

Tabela 17. Resultados da análise de variância molecular (AMOVA) de D. cayenensis. Piracicaba - SP, 2005

\begin{tabular}{cccc}
\hline Fonte de variação & GL & SQ & $\begin{array}{c}\text { Porcentagem da variação } \\
\text { total }\end{array}$ \\
\hline Entre comunidades & 13 & 141,45 & 40,26 \\
Entre roças dentro de comunidades & 3 & 17,00 & 42,54 \\
Dentro de roças dentro de & 4 & 5,83 & 17,20 \\
comunidades & & & \\
Total & 20 & 164,29 & \\
\hline
\end{tabular}


A distribuição da variabilidade está relacionada à recombinação gênica, pois o sistema sexual desta espécie permaneceu ativo. Aliado a este fator existe todo manejo inconsciente do agricultor tradicional que favorece o aumento de diversidade genética.

Peroni (1998) demonstra as relações do manejo agrícola com os componentes de história vital da mandioca nas roças de agricultura tradicional do Vale do Ribeira, pois a perturbação humana favorece os processos microevolutivos e, conseqüentemente, a manutenção da variabilidade genética mantida pelos agricultores.

\subsubsection{Avaliação morfológica}

A análise de agrupamento para as 21 etnovariedades de $D$. cayenensis e dois acessos de $D$. rotundata, obtidas por este método, revelou a formação de seis grupos ( I a VI), nos quais os acessos foram distribuídos da seguinte forma: I (1,2 e 3); II (4, 5 e 8); III (6, 7, 9, 10 e 11); IV (12, 14, 15, 16, 17, 18, 19, 20 e 21$)$; V (13 e 22) e VI (23) (Figura 28).

O coeficiente de similaridade de Jaccard entre os indivíduos $16,17,18$ da roça 14 em Pedrinhas, 19 da roça 15 em Nhunguara, 20 da roça 16 e 21 da roça 17, ambas de Sapatu, apresentou coeficiente de similaridade igual a 1. Esses indivíduos apresentam, portanto, o mesmo fenótipo morfológico, embora tenham sido coletados em comunidades diferentes do Vale do Ribeira (Tabela 5 e Figura 5). No entanto, Nhunguara e Sapatu são mais próximas geograficamente, sendo ambas comunidades quilombolas dos municípios de Iporanga e Eldorado Paulista.

Pela análise de agrupamento para descritores morfológicos, verificamos que não houve uma separação das espécies do complexo $D$. cayenensis/D.rotundata como ocorreu na avaliação isoenzimática. Este complexo foi estudado através das técnicas de isoenzimas e análises morfológicas por Hamon \& Toure (1990) que avaliaram 453 acessos cujo resultado mostrou boa concordância entre ambas as técnicas. Mignouna et al. (2002) também empregaram estas técnicas com sucesso na identificação de cultivares de inhame do complexo $D$. cayenensis/rotundata em Camarões no Oeste da África. 


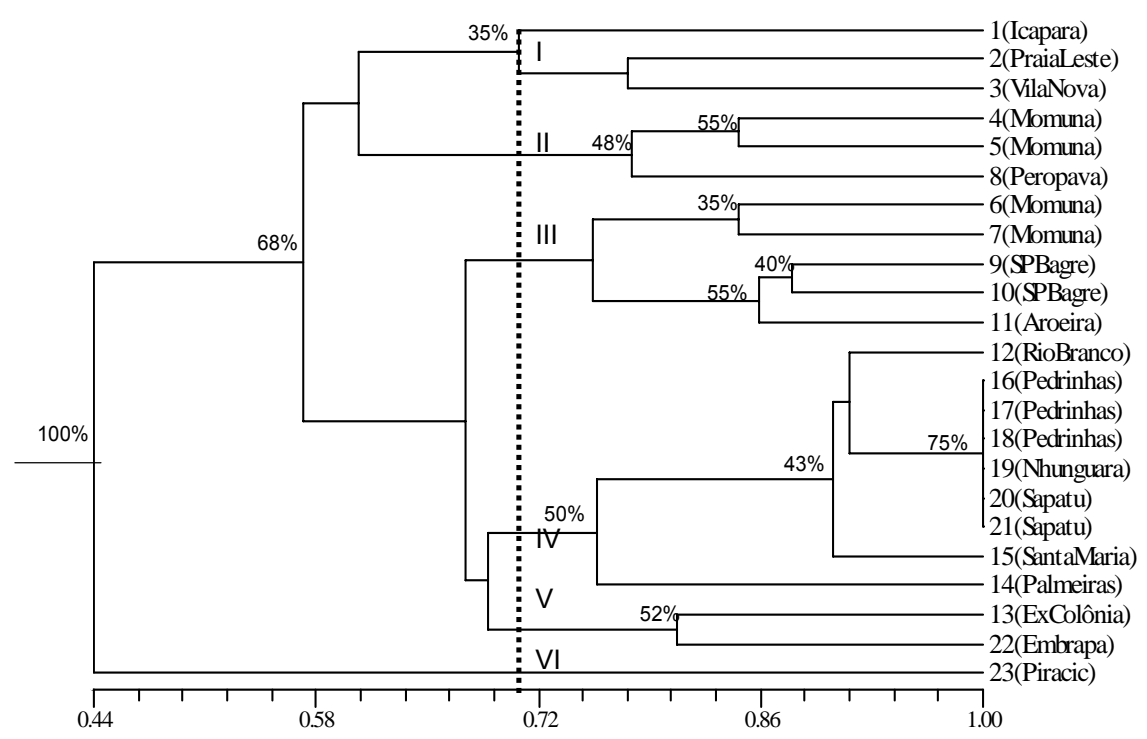

Figura 28 - Análise de agrupamento pelo método aglomerativo UPGMA relativo a 21 etnovariedades de $D$. cayenensis e dois acessos de $D$. rotundata, com base em 24 caracteres morfológicos, de acordo com a similaridade do índice de Jaccard. Piracicaba-SP, 2005

No caso brasileiro as etnovariedades cultivadas pelos agricultores tradicionais possuem uma variação de similaridade de $56 \%$, para os caracteres morfológicos.

Entre as comunidades que cultivam $D$. cayenensis e os locais de coleta de $D$. rotundata, observaram-se a formação de cinco grupos ( $\mathrm{a} V$ ), nos quais as comunidades foram distribuídas da seguinte forma: I (Icapara); II (Praia do Leste e Vila Nova); III (Momuna); IV (Peropava, São Paulo Bagre, Aroeira, Rio Branco e Piracicaba) e V (Ex-Colônia, Palmeiras, Santa Maria, Pedrinhas, Nhunguara, Sapatu e Embrapa) (Figura 29).

Existe grande diversidade entre as unidades culturais quanto a morfologia, pois encontrou-se $42 \%$ de similaridade entre as comunidades 


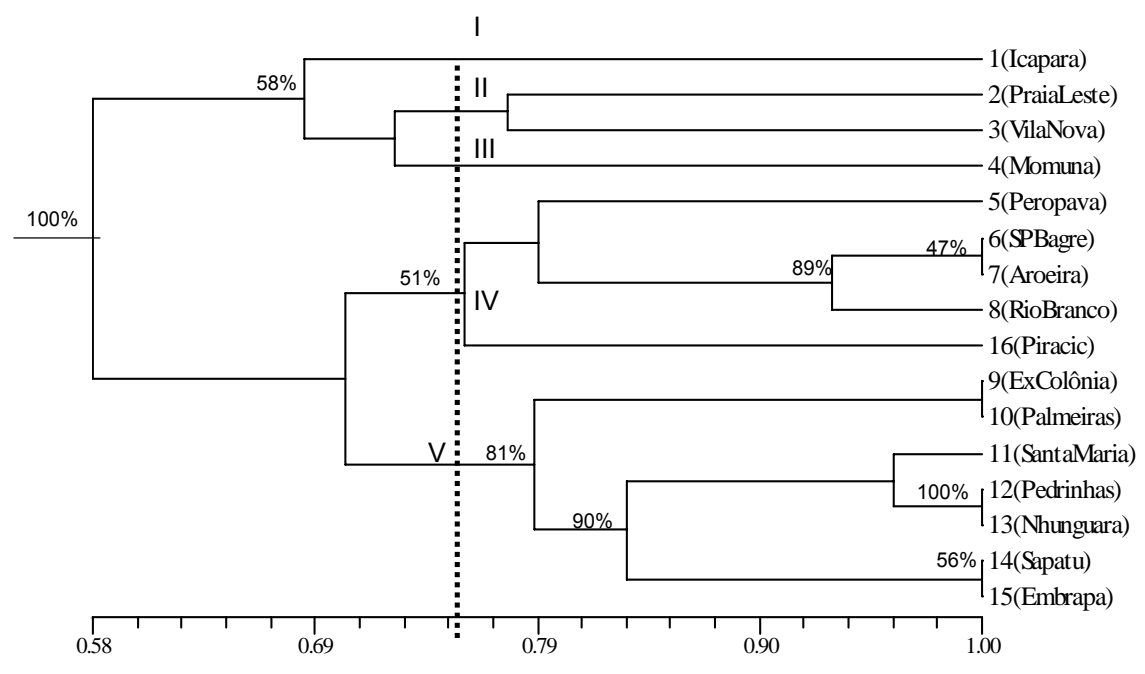

Figura 29 - Análise de agrupamento pelo método aglomerativo UPGMA relativo a 14 comunidades que cultivam $D$. cayenensis e dois locais de $D$. rotundata, com base em 24 caracteres morfológicos, de acordo com a similaridade do índice de Jaccard. Piracicaba-SP, 2005

Os nomes comuns dados pelos agricultores tradicionais do Vale do Ribeira para D. cayenensis ("cará de espinho", "cará d'angola" e "cará guaçu") encobriu a diversidade genética dentro das comunidades e municípios. A maioria dos agricultores denomina esta espécie de "cará de espinho", embora os resultados tenham demostrado grandes divergências genéticas entre as etnovariedades. "Cará guaçu" e "Cará d'angola" foram dados por dois e um agricultores, respectivamente, sendo que o nome "cará guaçu" foi também atribuído a outra espécie de inhame (D. alata).

Não observou-se correlação entre as distâncias genéticas e geográficas ( $r=$ 0,05), sugerindo que a distribuição das etnovariedades está ligada a fatores antrópicos, como os hábitos culturais de cada comunidade e geração de diversidade via sistema reprodutivo sexual.

Através da análise de variância molecular (AMOVA), verificou-se que 44,81\% da variabilidade encontra-se entre roças dentro de comunidades (Tabela 18), seguida de $36,58 \%$ entre as comunidades. 
Tabela 18. Resultados da análise de variância molecular (AMOVA)

\begin{tabular}{cccc}
\hline Fonte de variação & GL & SQ & $\begin{array}{c}\text { Porcentagem total de } \\
\text { variação }\end{array}$ \\
\hline Entre comunidades & 13 & 77,74 & 36,58 \\
Entre roças dentro de comunidades & 3 & 10,00 & 44,81 \\
Dentro de roças dentro de & 4 & 3,50 & 18,61 \\
comunidades & & & \\
Total & 20 & 91,24 & \\
\hline
\end{tabular}

A maior parte da diversidade morfológica está distribuída entre roças dentro de comunidades. Desta forma, a diversidade está sendo gerada, pela reprodução sexual ou por outros fatores evolutivos, além da seleção humana através de características morfológicas de interesse tendo como parâmetro os hábitos culturais de sua comunidade. Martins (2001) cita que o agricultor não seleciona as sementes para a perda de dormência como é o caso das gramíneas e leguminosas domesticadas, porque a propagação do inhame ( $D$. cayenensis) é feita através dos tubérculos, o que possibilita a formação de bancos de sementes no solo.

Esta espécie foi introduzida no Brasil pelos escravos. Na região do Vale do Ribeira encontramos muitas comunidades quilombolas como Mandira, Porto do Meio, Nhunguara, Sapatu que conservam a diversidade de seus povos. Além disso, esta espécie é cultivada em roças de pousio, onde os agricultores utilizam como "banco de germoplasma" para a abertura de novas roças e local de caça, pois, os animais buscam alimentos nas roças abandonadas pelo homem. Aliado a estes fatores alguns agricultores relatam a presença de flores e frutos para esta espécie.

Os descritores morfológicos selecionados permitiram descriminação da variabilidade genética existente entre as etnovariedades e entre as unidades evolutivas (roças e comunidades) que cultivam a espécie $D$. cayenensis no Vale do Ribeira e os dois acessos de $D$. rotundata. O florescimento foi o descritor mais importante para a espécie $D$. cayenensis. Observou-se que nas condições bióticas e abióticas do banco de germoplasma em Piracicaba somente $17 \%$ das etnovariedades produziram flores, frutificações e sementes. Esse dado é importante, pois, existe para essa espécie a possibilidade de geração de variabilidade genética através de cruzamentos. Embora o agricultor ignore a reprodução sexual do "cará de espinho" e o propague 
vegetativamente, o sistema sexual desta espécie permaneceu ativo, pois, alguns agricultores relataram a presença de flores e frutos para esta espécie. Outro ponto que chama a atenção é a manutenção desta espécie em roças abandonadas (pousio). Durante um levantamento em uma comunidade caiçara (Pedrinhas) na llha Comprida, e em uma comunidade quilombola, Ivaporunduva, que foram encontradas sementes de inhame (Dioscorea spp.) na camada superficial do solo $(10 \mathrm{~cm}$ de profundidade) reforçando, desta forma, a possibilidade de amplificação da variabilidade genética através da reprodução sexual (Martins, 2001).

\subsubsection{Correlação entre estimativas isoenzimáticas e morfológicas}

Para D. cayenensis, o coeficiente obtido entre as estimativas isoenzimáticas e morfológicas foi nula $(r=-0,05)$ e não significativa estatisticamente ( $p=0,99$ ), sugerindo que esses dois parâmetros não estão corelacionados. Os indivíduos que se apresentaram idênticos para os padrões isoenzimáticos (4-5 e 15-16) (Figura 23), mostraram-se diferentes morfológicamente (Figura 25), embora com diferenças de pequena magnitude.

Desta forma, fica claro que o agricultor depara-se com algumas variações morfológicas que não refletem as diferenças isoenzimáticas, pois para a espécie $D$. cayenensis no Vale do Ribeira a ação da reprodução sexual e dos processos microevolutivos em conjunto com as habilidades do agricultor de seleção agem na variabilidade "observada" claramente discriminada pela morfologia das plantas, como sobre a variabilidade "oculta" que o agricultor não conhece (genes).

Quiros et al. (1990) demonstram em seu trabalho com batatas nos Andes peruanos a subestimação da variabilidade genética na agricultura autóctone.

\subsection{Conclusões}

As informações obtidas com a estimação da diversidade genética (isoenzimática e morfológica) revelaram que os agricultores tradicionais mantêm e manejam grande variabilidade em suas comunidades, portanto, ambos os marcadores foram adequados para o estudo da diversidade de $D$. cayenensis. Porém, não existe 
concordância entre o sistema de taxonomia "folk" e os marcadores genéticos, pois, a noção de "variedade" do agricultor encobre grandes níveis de diversidade dentro de uma mesma comunidade ou município.

Contudo, os marcadores isoenzimáticos foram mais informativos que os morfológicos, pois os agrupamentos formados mostraram a separação das espécies do complexo $D$. cayenensis/rotundata do banco de germoplasma do LEEGA/ESALQ/USP, além da separação das etnovariedades.

A maior parte da diversidade, mesmo não estando estruturada no espaço, encontra-se para $D$. cayenensis entre roças tradicionais dentro de comunidades do Vale do Ribeira.

Finalmente, recomenda-se maior detalhamento sobre a reprodução sexual e suas contribuições para amplificação da diversidade desta espécie. 


\section{CONCLUSÕES GERAIS}

Os resultados obtidos a partir das hipóteses levantadas e dos objetivos desta pesquisa, geraram as seguintes conclusões:

- Quatro espécies de Dioscorea foram encontradas nas roças e quintais dos agricultores tradicionais do Vale do Ribeira: $D$. alata, $D$. bulbifera, $D$. cayenensis e $D$. trifida;

- A maior parte das etnovariedades de inhame são mantidas nos quintais pelos agricultores tradicionais do Vale do Ribeira;

- Os marcadores isoenzimáticos e morfológicos detectaram grande variabilidade genética para as espécies de Dioscorea, portanto, ambos os marcadores são adequados para o estudo da diversidade da cultura do inhame;

- Não existe correlação entre os marcadores genéticos para as quatro espécies;

- Contudo, os marcadores isoenzimáticos foram mais informativos que os morfológicos, pois, verificou-se um melhor agrupamento entre as etnovariedades e os materiais comerciais;

- Os marcadores utilizados para esta pesquisa demonstraram que a variabilidade genética para as espécies de inhame (Dioscorea spp.), coletadas nas roças e quintais dos agricultores tradicionais do Vale do Ribeira, não estavam estruturadas no espaço;

- A maior parte da variabilidade isoenzimática encontra-se, para as espécies $D$. trifida, $D$. bulbifera e $D$. cayenensis, entre roças dentro de comunidades, enquanto que para $D$. alata concentra-se dentro de roças. Para os marcadores morfológicos, a maior parte da variabilidade concentra-se entre roças dentro de comunidades para $D$. bulbifera e $D$. cayenensis e dentro de roças para $D$. alata e $D$. trifida;

- As informações revelaram que as restrições às áreas de plantio devido a questões como a legislação ambiental vigente para a Floresta Atlântica não causou até 
o momento redução na diversidade genética das espécies cultivadas na agricultura autóctone do Vale do Ribeira.

Os resultados obtidos neste estudo também indicaram que outras questões devem ser aprofundadas:

- Estudos mais detalhados sobre as pressões sofridas pela agricultura autóctone no Vale do Ribeira e suas possíveis alterações nos níveis de diversidade manejada pelos agricultores tradicionais do Vale do Ribeira;

- Novos estudos são necessários para se conhecer com mais detalhes a dinâmica evolutiva da cultura do inhame (Dioscorea spp.) in situ no Vale do Ribeira;

- Pesquisas mais detalhadas sobre a reprodução sexual e suas contribuições para a amplificação da diversidade das espécies de inhame, em especial $D$. cayenensis;

- Em suma, recomendam-se estudos mais detalhados a respeito do conhecimento e peculiaridades da agricultura tradicional no Vale do Ribeira, observando-se a grande variedade de nomes populares atribuídos as etnovariedades, bem como diferentes usos na alimentação e farmacêutico, tendo em vista as tendências observadas na presente pesquisa. 


\section{REFERÊNCIAS BIBLIOGRÁFICAS}

ABRAMO, M.A. Taioba, cará e inhame. São Paulo: Ícone, 1990. p. 65-80.

ALFENAS, A.C.; PETERS, I.; BRUNE, W. et al. Eletroforese de proteínas e isoenzimas de fungos e essências florestais. Viçosa: UFV, 1991. 242p.

ALFENAS, A.C. Eletroforese de isoenzimas e proteínas afins; fundamentos e aplicações em plantas e microrganismos. 2.ed. Viçosa: UFV, 1998. 370p.

ALTIERI, M.A.; MERRICK, L.C. "In situ" conservation of crop genetic resources through maintenance of traditional farming systems. Economic Botany, v.4, n.1, p.86-96, 1987.

ALTIERI, M.A. ?Por que estudiar la agricultura tradicional? http://www. clades.org/r1-art2.htm (5 May 2002)

ALVES, R.M. Caracterização genética de populações de cupuaçuzeiro, Theobroma grandiflorum (Willd ex. Spreng) Shum., por marcadores microssatélites e descritores botânico-agronômicos. Piracicaba, 2002. 146p. Tese (Doutorado) Escola Superior de Agricultura "Luiz de Queiroz", Universidade de São Paulo.

ASIEDU, R.; MAHALAKSHMI, V.; CHAIR, H. Assessment of genetic diversity of West African Dioscorea sp. collection.

http://www.generationcp.org/vw/Download/CommissionedResearch2005/pdf (4 May 2005)

BALLÉ, W "Indigenous history and Amazonian biodiversity". In: STEEN, H.; TUCKER, K. (Ed.). Changing tropical forest: historical perspectives on today's challenges in Central and South America. Durham: Forest History Society, 1992. p.185-197.

BALLÉ, W. Footprints of the forest: Ka'apor ethnobotany the historical ecology of plant utilization by Amazonian people. New York: Columbia University Press, 1993. v.2, p.47-56.

BRASIL. Código Florestal. Lei $n^{\circ} 4.771$ de 15 de setembro de 1965. http://www.dji.com.br/leis_ordinarias/1965-004771/004771-1965.htm (19 ago. 2004) 
BRESSAN, E.A.; VEASEY, E.A.; ZUCCHI, M.I.; VENCOVSKY, R. Caracterização da diversidade isoenzimática de Dioscorea trifida em roças de agricultura tradicional do Vale do Ribeira - SP (Compact disk). In: SIMPÓSIO SOBRE CONHECIMENTO TRADICIONAL E CONSERVAÇÃO DA AGROBIODIVERSIDADE, Piracicaba, 2004. Anais. Piracicaba: ESALQ - IPEF, 2004.

BRINER-NETO, T.; BRESSAN, E.A.; PERONI, N.; MELO, P.C.T.; VEASEY, E.A. Caracterização morfológica de etnovariedades de inhame (Dioscorea spp.) do município de Iguape, Vale do Ribeira, SP (Compact disk). In: CONGRESSO DA SOCIEDADE BOTÂNICA DE SÃO PAULO, 15., Ubatuba, 2004. Anais. Ubatuba: Sociedade de Botânica de São Paulo, 2004.

BRUSH, S.B. "In situ" conservation of landraces in centers of crop diversity. Crop Science, v.35, n.2, p.346-354, 1995.

BRUSH, S.B. The issues of in situ conservation of crop genetic resources. In: BRUSH, S.B. (Ed.). Genes in the field: on-farm conservation of crop diversity. Betherda: Lewis Publishers, 2000. 288p.

BUSO, G.S.C.; RANGEL, P.H.; FERREIRA, M.E. Analysis of genetic variability of South American wild rice populations (Oryza glumaepatula) with isozymes and RAPD markers. Molecular Ecology, v.7, p.107-117, 1998.

CARNEY, J.A.; MARIN, R.A. Saberes agrícolas dos escravos africanos no Novo Mundo. Ciência Hoje, v. 35, n. 205, p. 26-33, 2004.

CAVALLARI, M.M. Estrutura genética de populações de Encholirium (Bromeliaceae) e implicações para sua conservação. Piracicaba, 2004. 92p. Tese (Mestrado) Escola Superior de Agricultura "Luiz de Queiroz", Universidade de São Paulo.

CEREDA, M.P. Importância das tuberosas tropicais. In: CEREDA, M.P. (Ed.). Agricultura: tuberosas amiláceas Latino Americanas. São Paulo: Fundação Cargill. 2002a. p.13-25.

CEREDA, M.P. Justificativa para padronização dos nomes vulgares de Colocasia.e Dioscorea sp. no Brasil In: SIMPOSIO NACIONAL SOBRE AS CULTURAS DO INHAME E DO TARO, 2., João Pessoa, 2002. Anais. João Pessoa: EMEPA - PB, 2002b. p.306-307.

CLAWSON, L. Harvest security and intraspecific diversity in traditional tropical agriculture. Economic Botany, v.39, p.56-67, 1985. 
CLEVELAND, D.A.; SOLERI, D.; SMITH, E.S. Do folk crop varieties have a role in sustainable agriculture? BioScience, v.44, p.740-751, 1994.

COELHO, A.S.G. BOOD: Avaliação de dendrogramas baseados em estimativas de distâncias/similaridades genéticas através do procedimento de bootstrap (sofware). Goiânia: Universidade Federal de Goiás, Instituto de Ciências Biológicas, Laboratório de Genética Vegetal, 2001. 1 v.

COELHO, R.S.B. Resistência genética a doenças na cultura do inhame (Dioscorea spp.) In: SIMPOSIO NACIONAL SOBRE AS CULTURAS DO INHAME E DO TARO, 2., João Pessoa, 2002. Anais. João Pessoa: EMEPA - PB, 2002. v.2, p.111-121.

COELHO, A.S.G. BOOD-P: Avaliação de dendrogramas baseados em estimativas de distâncias/similaridades genéticas através do procedimento de bootstrap (sofware). Goiânia: Universidade Federal de Goiás, Instituto de Ciências Biológicas, Laboratório de Genética Vegetal, 2003. 1 v.

COLCHESTER, M. Salvaging nature: indigenous peoples and protected areas. In: GHIMIRE, K. PIMBERT, M. (Ed.). Social change and conservation: environmental politics and impacts of national parks and protected areas. Londres: Unrisd/Earthcan, 1997. p.78-95.

COLOMBO, C. A. Étude de la diversité génétique de maniocs américains (Manihot esculenta, Crantz) par lês marqueurs moléculaires (RAPD et AFLP). Montpellier, 1997. 145p. Thèse (Doctorat) - École Nationale Superieure Agronomique de Montpellier.

COURSEY, D.G. Yams. An account of the nature, origins, cultivation and utilization of the useful members of Dioscoreaceae. Londres: Longmans Green, 1967. p.78-91.

CURY, R. Dinâmica evolutiva e caracterização de germoplasma de mandioca (Manihot esculenta, Crantz) na agricultura autóctone. Piracicaba, 1993. 103 p. Tese (Mestrado) - Escola Superior de Agricultura "Luiz de Queiroz", Universidade de São Paulo.

CURY, R. Distribuição da diversidade genética e correlações de caracteres em etnovariedades de mandioca (Manihot esculenta, Crantz) provenientes da agricultura tradicional do Brasil. Piracicaba, 1998. 163 p. Tese (Doutorado) - Escola Superior de Agricultura "Luiz de Queiroz", Universidade de São Paulo. 
CHANG, J.H. Tropical agriculture: Crop diversity and crop yields. Economic Geographic, v. 53, p.241-254, 1977.

CHU, E. P. FIGUEIREDO, R. C. L. Native and exotic species of Dioscorea used as food in Brazil. Economic Botany, v.45, n.4, p.467-479, 1991.

DANSI, A.; ADOUKONOU, H.; MOUTAÏROUS, K. et al. The cultivated yams (Dioscorea cayenensis/Dioscorea rotundata complex) and their wild relatives in Benin Republic: diversity, evolutionary dynamic and in situ conservation. http://www.unu.edu/env/plec/cbd/Montreal/abstracts/Dansi.pdf (3 Feb. 2005)

DANSI, A.; PILLAY, M.; MIGNOUNA, H.D. et al. Ploidy level of the cultivated yams (Dioscorea cayenensis/D. rotundata complex) from Benin Republic as determined by chromosome counting and flow cytometry. African Crop Science Journal, v. 8, n. 4, p. 365-374, 2000.

DIAS, L.A.S. Divergência genética e fenética multivariada na predição de híbridos e preservação de germoplasma de cacau (Theobroma cação L.). Piracicaba, 1994. 94 p. Tese (Doutorado) - Escola Superior de Agricultura "Luiz de Queiroz", Universidade de São Paulo.

DIAS, L.A.S. Análises multidimensionais. In: ALFENAS, A.C. (Ed.). Eletroforese de isoenzimas e proteínas afins: fundamentos e aplicações em plantas e microorganismos. Viçosa: UFV, 1998. p. 401-475.

DIEGUES, A.C.S. O mito moderno da natureza intocada. São Paulo: Hucitec, 1996. $169 p$.

DIEGUES, A.C.S. 0 mito da natureza intocada. 3 ed. São Paulo: Hucitec, 2000a. $273 p$.

DIEGUES, A.C. S. Agregação de saberes tradicionais e etnoconservação. In: DIEGUES, A.C.; VIANA, V.M. (Ed.). Comunidades tradicionais e manejo dos recursos naturais da mata atlântica. São Paulo: NUPAUB/LABSTROPESALQ/USP, 2000b. p. 9-22.

DIEGUES, A.C.S.; ARRUDA, R.S. Saberes tradicionais e biodiversidade no Brasil. Brasília: Ministério do Meio Ambiente, 2001. 176 p. 
DI STATI, L. C. et al. Agregação de valor a produtos florestais manejados: 1 Espinheira -Santa e as suas adulterações; 2 Pariparoba e outras Piperaceae como novos produtos para comercialização. In: DIEGUES, A.C.; VIANA, V.M. (Ed.). Comunidades tradicionais e manejo dos recursos naturais da mata atlântica. São Paulo: NUPAUB/LABSTROP-ESALQ/USP, 2000. p. 65-94.

EMPERAIRE, L. O extrativismo, um componente de sistemas de produção complexos. In: MANEJO INTEGRADO DE FLORESTAS ÚMIDAS NEOTROPICAIS POR INDÚSTRIAS E COMUNIDADES, Belém, 2002. Anais. Belém: Museu Paraense Emilio Goeldi, 2002. p.298-306.

EMPRESA BRASILEIRA DE PESQUISA AGROPECUÁRIA. Princípios da técnica de eletroforese. http://www.cnpt.embrapa.br/biblio/p_do06f1.htm (12 maio 2004).

EXCOFFIER, L.; SMOUSES, P.E.; QUATTRO, J.M. Analysis of molecular variance inferred from metric distance among DNA haplotypes: application to human mitochondrial DNA restriction data. Genetics, v.131, p.479-491, 1992.

FALEIRO, F.G.; LOPES, U.V.; PIRES, J.L. et al. Comparação entre marcadores RAPD e microssatélites no estudo da diversidade genética no cacaueiro (Theobroma cacao I.). http://www.ceplac . gov.br/laboratórios/resumos 17.htm. (12 maio 2005)

FARALDO, M.I.F. Caracterização isoenzimática e diversidade de etnovariedades de mandioca (Manihot esculenta Crantz). Piracicaba, 1994. 91 p. Tese (Mestrado) Escola Superior de Agricultura "Luiz de Queiroz", Universidade de São Paulo.

FARALDO, M.I.F. Distribuição da variabilidade genética e caracterização isoenzimática de etnovariedades em roças de mandioca (Manihot esculenta Crantz) do Brasil. Piracicaba, 1999. 117 p. Tese (Doutorado) - Escola Superior de Agricultura "Luiz de Queiroz", Universidade de São Paulo.

FARALDO, M.I.F.; SILVA, R.M.; ANDO, A.; VEASEY, E. A. Marcadores moleculares em mandioca. In: CEREDA, M.P. (Ed.). Agricultura: tuberosas amiláceas Latino Americanas. São Paulo - Fundação Cargill. 2002. p. 36-48.

FELIPIM, A; RESENDE, R.; RIBEIRO, R.J. Agricultura de pousio e controle ambiental. In: DIEGUES, A.C.; VIANA, V.M. (Ed.). Comunidades tradicionais e manejo dos recursos naturais da mata atlântica. São Paulo: NUPAUB/LABSTROPESALQ/USP, 2000. p. 112-119. 
FERREIRA, M. E.; GRATTAPLAGLIA, D. Introdução ao uso de marcadores moleculares em análise genética. 3. ed. Brasília: EMBRAPA-CENARGEM, 1998. $220 p$.

FERREIRA JUNIOR, O. TrackMaker. http://www. www.gpstm.com/port/ (12 nov. 2004)

FISCHER, M.; HUSI, R.; PRATI, D. et al. RAPD variation among and within small and large populations of the rare clonal plant Ranunculus reptans (Ranunculaceae). American Journal of Botany, v.87, p.1128-1137, 2000.

FONSECA, G. Corredores de biodiversidade, uma solução para a vida ameaçada. www.biodiversidadebrasil.com.br (7 out. 2004)

FRANKEL, O.H. Genetic conservation in perspective. In: FRANKEL, O.H. (Ed.). Genetic resources in plants: their exploration and conservation. Oxford: Blackwell, 1970. p. 469-489.

FRANKEL, O.H.; BROWN, A.H.D.; BURDON, J.J. The conservation of plant biodiversity. Cambridge: Cambridge University Press, 1995. 299 p.

FRYER, J.H. Agreement between patterns of morphological variability and isozyme band phenotypes in pitch pine. Silvae Genetica, v. 36, n.5/6, p. 199-206, 1987.

FUNDAÇÃO SOS MATA ATLÂNTICA, INPE, ISA. Atlas da evolução dos remanescentes florestais e ecossistemas associados no domínio da Mata Atlântica no período 1990-1995. São Paulo: Fundação SOS Mata Atlântica, 1997.

GHIMIRE, K. Parques e populações: problemas de sobrevivência no manejo de parques nacionais na Tailândia e Madagascar. Trad. Cristina Adams. São Paulo: NUPAUB-USP/UNRISD, 1993. p. 113-145.

GILLIES, A.C.M.; NAVARRO, C.; LOWE, A.J., et al. Genetic diversity in Mesoamerican populations of mahogany (Swietenia macrophylla), assessed using RAPDs. Heredity, v.83, p.722-732, 1999.

GÓMEZ -POMPA, A. Possible papel de la vegetación secundária en la evolución de la flora tropical. Biotropica. v.3, p.125-135, 1971.

GÓMEZ -POMPA, A.; KAUS, A. Taming the wilderness myth. Bioscience, v.4, p.42, 1992.

HAMES, D.B. One-dimensional polyacrylamide gel electrophoresis. In: HAMES, D.B.; RICKWOOD, D. (Ed.). Gel electrophoresis of proteins: a practical approach. 2 ed. New York: Oxford University Press, 1996. p. 1-139. 
HAMON, J. R.; TOURE, B. Characterization of traditional yam varieties belonging to the Dioscorea cayensis-rotundata complex by their isozymic patterns. Euphytica, v. 46, n. 2, p. 101-107, 1990.

HANAZAKI, N.; LEITÃO-FILHO, H.F.; BEGOSSI, A. Uso de recursos na Mata Atlântica: o caso da Ponta Almada (Ubatuba, Brasil). Interciência, v.21, n.6, p.268-276, 1996.

HARLAN, J.R. Indigenous African agriculture. In: COWAN, C.W.; WATSON, P.J. (Ed.). The origins of agriculture. An international perspective. Washington D.C.: Smithsonian Institution Press, 1992. p. 59-70.

HARLAN, J.R. The living fields: our agricultural heritage. New York: Cambridge University Press, 1997. 217p.

HAWKES, J.G. Germplasm collection, preservation and use. In: FREY, K.J. (Ed.). Plant Breeding II. Ludhiana: Kaliany Publishers, 1982. p. 57-83.

HUFF, D.R.; PEAKALL, R.; SMOUSE, P.E. RAPD variation within and among natural populations of outcrossing buffalograss (Buchoe dactyloides (Nutt.) Elgen), Theoretical and Applied Genetics, v. 86, p.927-934, 1993.

IITA. International Institute of tropical agriculture. http://www.iita.org/search.htm (19 July 2002)

IPGRI/ITA. Descriptors for yam (Dioscorea spp.). Rome, Italy: International Institute of Tropical Agriculture, Ibadan, Nigeria/International Plant Genetic Resources Institute, 1997.61p.

JIMÉNEZ, J.F.; SANCHES-GÓMEZ, P.; GÜEMES, J. Genetic variability in a narrow endemic snapdragon (Antirrhinum subbaeticum, Scrophulariaceae) using RAPD markers. Heredity, v.89, p.387-393, 2002.

KLEE, G. A. World systems of traditional resource management. New York: Wiley, 1980. p. 95.

KNIGHT, C.G. Ethnoscience and the African farmer: rationale and strategy. In: BROKENSHAW, D. et al. (Ed.). Indigenous knowledge systems and development. Lanham: University Press of America, 1980. p. 203-229.

LADEIRA, M.I.; FELIPIM, A.P. Apoio à conservação ambiental de terras guarani e às atividades tradicionais de subsistência. In: DIEGUES, A.C.; VIANA, V.M. (Ed.). Comunidades tradicionais e manejo dos recursos naturais da mata atlântica. São Paulo: NUPAUB/LABSTROP-ESALQ/USP, 2000. p. 251-263. 
LADIZINSKY, G. Plant evolution under domestication. Dardrecht/Boston/London: Klurwer Academic Plublishers, 1998. 254p.

MAKI, M.; HORIE, S. Random amplified polymorphic DNA (RAPD) markers reveal less genetic variation in the endangered plant Cerastium fischerianum var. molle than in the widespread conspecific C. fischerianum var. fischerianum (Caryophyllaceae). Molecular Ecology, v.8, p.145-150, 1999.

MANLY, B.F.J. Randomization, bootstrap and Monte Carlo methods in biology. London: Chapman \& Hall, 1997. 281p.

MANTILA, J.E.; VARGAS, G. Propagación del name (Dioscorea alata L.) a partir de estacas herbáceas. Maracay: ALC,1984. v.33, p. 385-396.

MARIOT, A. REIS, M.S.; STASI, L.C.D. Fundamentos para o manejo de Piperáceas na Floresta Tropical Atlântica: demografia e fenologia reprodutiva. In: DIEGUES, A.C.; VIANA, V.M. (Ed.). Comunidades tradicionais e manejo dos recursos da mata atlântica. São Paulo: NUPAUB/LABSTROP-ESALQ/USP, 2000. p. 57-64.

MARTIN, A.; GALLO, J.T. Digestibilidad y energies digestibles y metabolizables del azúcar (Saccharum officinarum L.) y del name (Dioscorea alata) em cerdos. Colômbia: ICA, 1973. v. 2, p. 105-156.

MARTIN, F.W.; RHODES, A.M. The relationship of Dioscorea cayenensis and D. rotundata. Tropical Agriculture, v. 55, p.193-206, 1978.

MARTINS, P.S. Biodiversity and agriculture: patterns of domestication of Brazilian native plant species. Academia Brasileira de Ciências, v. 66, p. 119-226, 1994.

MARTINS, P.S. Dinâmica evolutiva em roças de caboclos amazônicos. In: VIEIRA, I.C. G. et al. (Org.). Diversidade biológica e cultural da Amazônia. Belém: Museu Paraense Emílio Goeldi, 2001. p. 369-384.

MASCARENHAS, M.H.T.; RESENDE, L.M.A. Situação atual e prospecção das culturas do inhame (Dioscorea alata) e do taro (Colocasia esculenta) no Sudeste do Brasil. In: SIMPOSIO NACIONAL SOBRE AS CULTURAS DO INHAME E DO TARO, 2., João Pessoa, 2002. Anais. João Pessoa: EMEPA - PB, 2002. p 33-51.

MELO, B. Inhame tem bom preço aqui e lá fora. Estado de São Paulo. Suplemento Agrícola, São Paulo. 22 set. 2004a. p. G4.

MELO, B. Assentados colhem primeira safra no RN. Estado de São Paulo. Suplemento Agrícola, São Paulo. 22 set. 2004b. p. G4. 
MIÈGE J. Nombre chromosomique et répartition géographique de quelques plantes tropicales et équatoriales. Revue Cytologie et Biologie Végétale. v.15, p.312-348, 1954.

MIGNOUNA H.D.; DANSI, A.; ZOK, S. Morphological and isozymic diversity of the cultivated yams (Dioscorea cayenensis/Dioscorea rotundata complex) of Cameroon. Genetic Resources and Crop Evolution, v.49, p.21-29, 2002.

MINISTÉRIO DO MEIO AMBIENTE. Diversidade brasileira.

http:// www. mma.gov.br/port/sbf/chm/biodiv/biodiv (15 ago. 2004)

MONTALDO, A. Cultivo de raíces y tubérculos tropicales. Lima: Instituto Interamericano de Ciências Agrícolas de la OEA, 1972. p. 24-50.

MONTALDO, A. Cultivo de raíces y tubérculos tropicales. Lima: Instituto Interamericano de Ciências Agrícolas de la OEA, 1991. p. 91-127.

MONTEIRO, D.A.; PERESSIM, V.A. Cultura do inhame. In: CEREDA, M.P. (Ed.). Agricultura: tuberosas amiláceas Latino Americanas. São Paulo: Fundação Cargill, 2002. p. 511-522

MORALES, E.A.V.; VALOIS, A.C.C. Recursos genéticos de vegetais autóctones e seus usos no desenvolvimento sustentável. Cadernos de Ciência \& Tecnologia, Brasília, v.17, n.2, p.11-42, 2000.

MORALES, E.A.V.; VALOIS, A.C.C.; NASS, L.L. Recursos genéticos vegetales. Brasília: EMBRAPA-SPI/EMBRAPA-CENARGEM, 1997. 78p.

MOURÃO, J.S.; NORDI, N. Comparações entre as taxonomias folk e científica para peixes do estuário do Rio Mamanguape, Paraíba-Brasil. Interciência, v. 27, n.12, p.664-668, 2002.

MURAYAMA, S. Horticultura. 2. ed. Campinas: Instituto Campineiro de Ensino Agrícola, 1999. p. 201-205.

NASS, L.L. Utilização de recursos genéticos vegetais no melhoramento. In: NASS, L.L.; VALOIS, A.C.C.; MELO, I.S.; VALDARES-INGLIS, M.C. (Ed.). Recursos genéticos e melhoramento - plantas. Rondonópolis: Fundação MT. 2001. p. 29-55.

NEIMAN, Z. Era verde?: ecossistemas brasileiros ameaçados. 10.ed. São Paulo: Atual, 1989. p. 35-48.

NOORGARD, R.B. Development betrayed. The end of progress and a coevolutionary revisioning of the future. Routledge, v. 8, n. 4, p. 72-95, 1994. 
NORMAN, M.J.T. Annual cropping systems in the tropics. Gainnesville: University Press of Florida, 1979. p. 75-82.

OLIVEIRA, A.C.B.; SEDIYAMA, M.A.N. SDIYAMA, T. et al. Variabilidade genética em batata-doce com base em marcadores isoenzimáticos. Horticultura Brasileira, v. 20, n. 4, p.576-582, 2002.

OLIVEIRA, R. R. LIMA, D.F.; SAMPAIO, P.D. et al. Roça Caiçara: um sistema autosustentável. Ciência Hoje, v. 18, n. 104, p. 44-51, 1994.

ONYILAGHA, J. C. Numerical analysis of variation among Nigerian Dioscorea rotundata accessions. Euphytica, v. 35, n. 2, p. 413-419, 1986.

PEDRALLI, G. O inhame, esse desconhecido. Ciência Hoje, v. 8, n. 46, p.58-62. 1988.

PEDRALLI, G. Collecting yam germplasm in Brazil. Plant Genetic Resources Newsletter, v. 22, p. 83-84, 1990.

PEDRALLI, G. Collecting wild relatives of yam (Dioscorea spp.) in the Espinhaço range, Brazil. Plant Genetic Resources Newsletter, v. 51, p.97, 1994.

PEDRALLI, G. Uso de nomes populares para as espécies de Araceae e Dioscoreaceae. In: SIMPOSIO NACIONAL SOBRE AS CULTURAS DO INHAME E DO TARO, 2., João Pessoa, 2002. Anais. João Pessoa: EMEPA - PB, 2002. p. 308-311.

PERONI, N. Taxonomia folk e diversidade intraespecífica de mandioca (Manihot esculentas Crantz) em roças de agricultura tradicional em áreas de Mata Atlântica do Sul do Estado de São Paulo. Piracicaba, 1998. 196 p. Tese (Mestrado) - Escola Superior de Agricultura "Luiz de Queiroz", Universidade de São Paulo.

PERONI, N.; MARTINS, P.S. Influência da dinâmica agrícola itinerante na geração de diversidade de etnovariedades cultivadas vegetativamente. Interciência, v.25, n.1, p.22-29, 2000.

PERONI, N.; HANAZAKI, N. Current and lost diversity of cultivated varieties, especially cassava, under swidden cultivation systems in the Brazilian Atlantic Forest. Agriculture, Ecosystems and Environment, v.92, n.2/3, p.171-183, 2002.

POSEY, D.A. Introdução - Etnobiologia: teoria e prática. In: RIBEIRO, D. (Ed.). Suma etnológica brasileira. 2 ed. Petrópolis: Vozes, 1987. p. 15-25.

QUEIRÓZ, M.A. Os recursos vegetais e os melhoristas de plantas. http://www.cpatsa.embrapa.br ( 28 julho 2004) 
QUEROL, D. Recursos genéticos, nosso tesouro esquecido: abordagem sócioeconômica. Rio de Janeiro: AS-PTA, 1993. 206p.

QUIROS, C.F; BRUSH, S.B.; DOUCHES, D.S. et al. Biochemical and folk assessment of variability of Andean cultivated potatoes. Economic Botany, v.44, n.2, p. 254-266, 1990.

RHODES, A.M.; MARTIN, F.W. Multivariate studies of variation in yams (Dioscorea alata L.). Journal of The American Society for Horticultural Science, v. 97, p. 685-688, 1972.

RHOADES, R.E. Breaking new ground: agricultural anthropology. Lima: International Potato Center, 1984. 85p.

ROHLF, J. NTSYS-pc: numerical taxonomy and multivariate analysis system, version 1.70 (software). New York: Stony Brook, 1992.

SAMBATTI, J.B.M. Erosão genética e conservação de germoplasma de mandioca na agricultura autóctone em Ubatuba-SP. Piracicaba, 1998. 165 p. Tese (Mestrado) Escola Superior de Agricultura "Luiz de Queiroz”, Universidade de São Paulo.

SAMBATTI, J.B.M.; MARTINS, P.S.; ANDO, A. Folk taxonomy and evolutionary dynamics of cassava: a case study in Ubatuba, Brazil. Economic Botany, v. 55, n. 1, p. 93-105, 2001.

SANTOS, E.S.; MACÊDO, L.S. Tendência e perspectiva da cultura do inhame (Dioscorea sp.) no Nordeste do Brasil. In: SIMPOSIO NACIONAL SOBRE AS CULTURAS DO INHAME E DO TARO, 2., João Pessoa, 2002. Anais. João Pessoa: EMEPA - PB, 2002, p 22-31.

SANTOS, E.S. Esclarecimentos sobre as denominações dos gêneros Dioscorea e Colocasia. In: SIMPOSIO NACIONAL SOBRE AS CULTURAS DO INHAME E DO TARO, 2., João Pessoa, 2002. Anais. João Pessoa: EMEPA - PB, 2002. p. 303-305.

SCHNEIDER, S.; ROESSLI, D.; EXCOFFIER, L. Arlequim ver. 2000: a software for population data analysis. (Software). Geneva: University of Geneva, Genetic and Biometry laboratory, 2000. http://anthropologie.unige.ch/arlequin (14 Oct. 2004)

SEAGRI. Cultura do cará. http://www. seagri.ba.gov.br/Cará.htm (21 nov. 2001)

SEGNOU, C.; FATOKUN, A.; AKORODA, M.O. et al. Studies on the reproductive biology of white yam (Dioscorea rotundata Poir). Euphytica, v. 64, n. 3, p. 197-203, 1992. 
SILVA, A.A. Cultura do Cará da Costa. Fortaleza: Instituto de Pesquisas Agronômicas da Secretaria de Agricultura de Pernambuco, 1971. 66p.

SILVA, R.M. Sistema reprodutivo, fluxo gênico e paternidade em roça de etnovariedades de mandioca. Piracicaba, 2000. 131 p. Tese (Doutorado) - Escola Superior de Agricultura "Luiz de Queiroz", Universidade de São Paulo.

SILVA, R.M.; BANDEL, G.; MARTINS, P.S. Mating system in an experimental garden composed of cassava (Manihot esculenta Crantz) ethnovarieties. Euphytica, v.134, p.127-135, 2003.

SOLTIS, D.E.; HAUFLER, C.H.; DARROW, D.C. et al. Starch gel electrophoresis of ferns: a compilation of grinding buffers, gel and electrode buffer, and staining schedules. American Fern Journal, v. 73, p. 9-27, 1983.

SOLTIS, D.E.; SOLTIS, P.E. Isozymes in plant biology. London: Chapman and Hall, 1990. 268p.

SMITHIES, O. Zone electrophoresis in starch gels. Biochemical Journal, v. 61, p. $629,1955$.

TELLES, M.P.C; SILVA, R.S.M.; CHAVES, L.J. et al. Divergência entre subpopulações de cagaiteira (Eugenia dysenterica) em resposta a padrões edáficos e distribuição espacial. Pesquisa Agropecuária Brasileira, v. 36, n. 11, p. 1387-1394, 2001.

TELLES, M.P.C; VALVA, F.D.; BANDEIRA, L.F. et al. Caracterização genética de populações naturais de araticunzeiro (Annona crassiflora Mart. - Annonaceae) no Estado de Goiás. Revista Brasileira de Botânica, v.26, n.1, p.123-129, 2003.

TORGGLER, M.G.F.; CONTEL, E.P.B.; TORGGLER, S.P. Isoenzimas: variabilidade genética em plantas. Ribeirão Preto: Sociedade Brasileira de genética, 1995.186p.

TRIP. Sistema agrícola Caiçara. http://www.trip.com.br/Caiçara/agri.htm (5 maio 2002)

TWYFORD , C.T.; VIANA, A.M.; JAMES, A.C. et al. Characterizaion of species and vegetative clones of Dioscorea food yams using isoelectric focusing of peroxidase and acid phosphatade isoenzymes. Tropical Agriculture, v. 67, n. 4, p. 337-341, 1990.

VEASEY, E.A. Variabilidade genética em acessos de espécies de Sesbania Scop. (Leguminosae): caracterização morfológica, agronômica e isoenzimática. Piracicaba, 1998. 141 p. Tese (Doutorado) - Escola Superior de Agricultura "Luiz de Queiroz", Universidade de São Paulo. 
VEASEY, E.A.; SANTOS, P.P.; ROSA, M.S.; BRESSAN, E.A.; PERONI, N. Diversidade genética baseada em caracteres morfológicos de etnovariedades de batata-doce (Ipomoea batatas (L.) Lam.) do Vale do Ribeira (compact disk). In: CONGRESSO DA SOCIEDADE BOTÂNICA DE SÃO PAULO, 15., Ubatuba, 2004. Anais. Ubatuba: Sociedade de Botânica de São Paulo, 2004.

ZERATE, N.A.H.; VIEIRA, M.C.; SIQUEIRA, J.G. Produção de quatro clones de cará em Dourados/MS. Horticultura Brasileira, v. 14, n. 1, p. 56-60, 1996.

ZEVEN, A.C. A review of definitions and classifications. Euphytica, v.104, n.2, p.127-139, 1998.

ZOUNDJIHEKPON, J.; HAMON, S.; TIO-TOURÉ, B. et al. First controlled progenies checked by isozymic markers in cultivated yams Dioscorea cayenensis-rotundata. Theoretical Applied Genetics, v. 88, n. 8, p. 1011-1016, 1994.

ZOUNDJIHEKPON, J.; HAMON, P.; NOIROT, M. et al. Flowering synchronization between male and female West African cultivated yams (Dioscorea cayenensisrotundata complex). Euphytica, v. 95, n. 1, p. 371-375, 1997.

ZUCCHI, M.I. Análise da estrutura genética de Eugenia dysenterica DC utilizando marcadores RAPD e SSR. Piracicaba, 2002. 130p. Tese (Doutorado) - Escola Superior de Agricultura "Luiz de Queiroz", Universidade de São Paulo. 


\section{APÊNDICES}


APÊNDICE 1. Protocolo das reações histoquímicas para os marcadores isoenzimáticos utilizados em espécies de Dioscorea

\section{- Fosfoglucomutase (PGM)}

$\begin{array}{ll}\text { Glucose-1-fosfato, } \mathrm{Na}_{2} & 0,125 \mathrm{~g} \\ \text { EDTA } & 0,025 \mathrm{~g} \\ \text { NADP } & 1 \mathrm{~mL}(10 \mathrm{mg} / \mathrm{mL}) \\ \text { MTT ou NBT } & 1 \mathrm{~mL}(10 \mathrm{mg} / \mathrm{mL}) \\ \text { PMS } & 1 \mathrm{~mL}(1 \mathrm{mg} / \mathrm{mL}) \\ \mathrm{MgCl}_{2}(1 \%) & 1 \mathrm{~mL}(10 \mathrm{mg} / \mathrm{mL}) \\ \text { Tris-HCl 0,1M pH8,5 } & 50 \mathrm{~mL} \\ \text { Glucose-6-fosfato desidrogenase } & 0,02 \mathrm{~mL}\end{array}$

Procedimento: $\mathrm{O}$ gel foi mergulhado na solução e incubado no escuro à $37^{\circ} \mathrm{C}$, até o aparecimento das bandas.

- Glucose-6-fosfato desidrogenase $\left(\mathrm{G}_{6} \mathrm{PDH}\right)$

Glucose-1-phosphate

NADP

$0,20 \mathrm{~g}$

MTT ou NBT

$0,38 \mathrm{~mL}(10 \mathrm{mg} / \mathrm{mL})$

PMS

$1 \mathrm{~mL}(10 \mathrm{mg} / \mathrm{mL})$

$\mathrm{MgCl}_{2}(1 \%)$

Tris- $\mathrm{HCl} 0,1 \mathrm{M} \mathrm{pH} 7,5$

$0,2 \mathrm{~mL}(1 \mathrm{mg} / \mathrm{mL})$

$0,5 \mathrm{~mL}(10 \mathrm{mg} / \mathrm{mL})$

$50 \mathrm{~mL}$

Procedimento: $\mathrm{O}$ gel foi mergulhado na solução e incubado no escuro à $37^{\circ} \mathrm{C}$, até o aparecimento das bandas.

\section{- Glucose-6-fosfato isomerase (GPI)}

Frutose-6-phosfato

NADP

MTT ou NBT

PMS

Tris- $\mathrm{HCl} 0,1 \mathrm{M} \mathrm{pH} 7,5$

Glucose-6-fosfato desidrogenase

$0,04 \mathrm{~g}$

$0,5 \mathrm{~mL}(10 \mathrm{mg} / \mathrm{mL})$

$1 \mathrm{~mL}(10 \mathrm{mg} / \mathrm{mL})$

$0,2 \mathrm{~mL}(10 \mathrm{mg} / \mathrm{mL})$

$50 \mathrm{~mL}$

$0,05 \mathrm{~mL}$

Procedimento: $\mathrm{O}$ gel foi mergulhado na solução e incubado no escuro à $37^{\circ} \mathrm{C}$, até o aparecimento das bandas.

\section{- Glutamato oxaloacetato transaminase (ATT)}

Fast Blue BB

Piridoxal - 5 - Fosfato

Ácido L-aspártico

Ácido a-cetoglutárico

Tampão C

Tampão D
$0,15 \mathrm{~g}$

$0,001 \mathrm{~g}$

$0,06 \mathrm{~g}$

$0,036 \mathrm{~g}$

$8,0 \mathrm{~mL}$

$42,0 \mathrm{~mL}$ 
Tampão C $(0,2 \mathrm{M} \mathrm{pH} \mathrm{4,3)}$

$\mathrm{NaH}_{2} \mathrm{PO}_{4}$

$\mathrm{H}_{2} \mathrm{O}$ destilada

Tampão D $(0,2 \mathrm{M} \mathrm{pH} \mathrm{9,2)}$

$\mathrm{Na}_{2} \mathrm{HPO}_{4}$

$\mathrm{H}_{2} \mathrm{O}$ destilada

$27,6 \mathrm{~g}$

$1000 \mathrm{~mL}$

$53,65 \mathrm{~g}$

$1000 \mathrm{~mL}$

Procedimento: $\mathrm{O}$ gel foi mergulhado na solução e incubado no escuro à $37^{\circ} \mathrm{C}$, até o aparecimento das bandas.

\section{- Malato desidrogenase (MDH)}

NAD

MTT ou NBT

$3,3 \mathrm{~mL}(10 \mathrm{mg} / \mathrm{mL})$

PMS

Tris-Ácido Málico 0,5M pH 8,5

$1,2 \mathrm{~mL}(10 \mathrm{mg} / \mathrm{mL})$

$1,5 \mathrm{~mL}(1 \mathrm{mg} / \mathrm{mL})$

$50 \mathrm{~mL}$

Procedimento: $\mathrm{O}$ gel foi mergulhado na solução e incubado no escuro à $37^{\circ} \mathrm{C}$, até o aparecimento das bandas.

- Superóxido dismutase (SOD)

Riboflavina

EDTA

MTT ou NBT

Tris- $\mathrm{HCl} 0,05 \mathrm{M} \mathrm{pH8,5}$

$0,002 \mathrm{~g}$

$0,15 \mathrm{~g}$

$1,0 \mathrm{~mL}(10 \mathrm{mg} / \mathrm{mL})$

$50 \mathrm{~mL}$

Procedimento: O gel foi mergulhado na solução e incubado exposto à luz à $37^{\circ} \mathrm{C}$, até o aparecimento das bandas acromáticas.

\section{- Xiquimato desidrogenase (SKDH)}

Ácido xiquímico

NADP

MTT ou NBT

PMS

Tris- $\mathrm{HCl} 0,1 \mathrm{M} \mathrm{pH} 8,5$

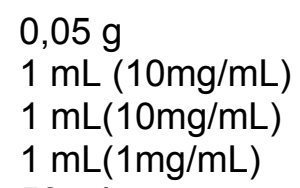

Procedimento: $\mathrm{O}$ gel foi mergulhado na solução e incubado no escuro à $37^{\circ} \mathrm{C}$, até o aparecimento das bandas. 


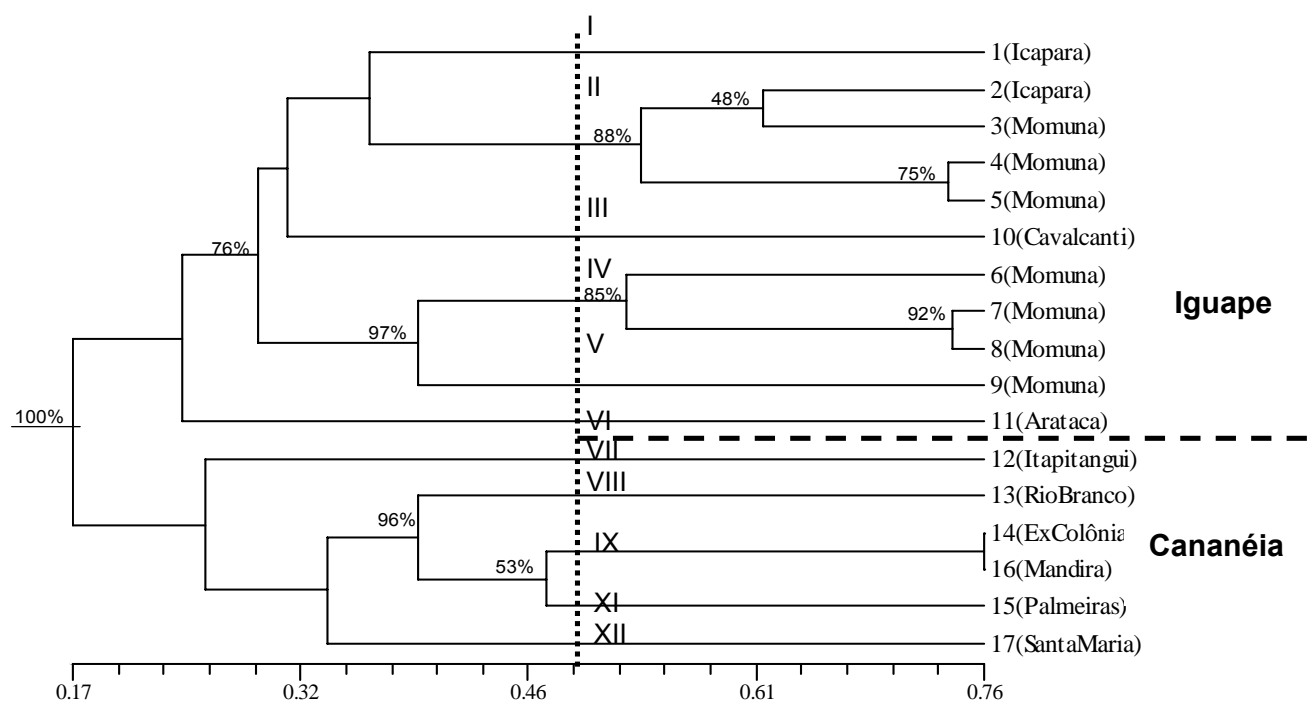

APÊNDICE 2 - Análise de agrupamento pelo método aglomerativo UPGMA relativo a 17 roças que cultivam $D$. trifida, com base em 64 bandas isoenzimáticas, de acordo com a similaridade do índice de Jaccard. Piracicaba - SP, 2005 


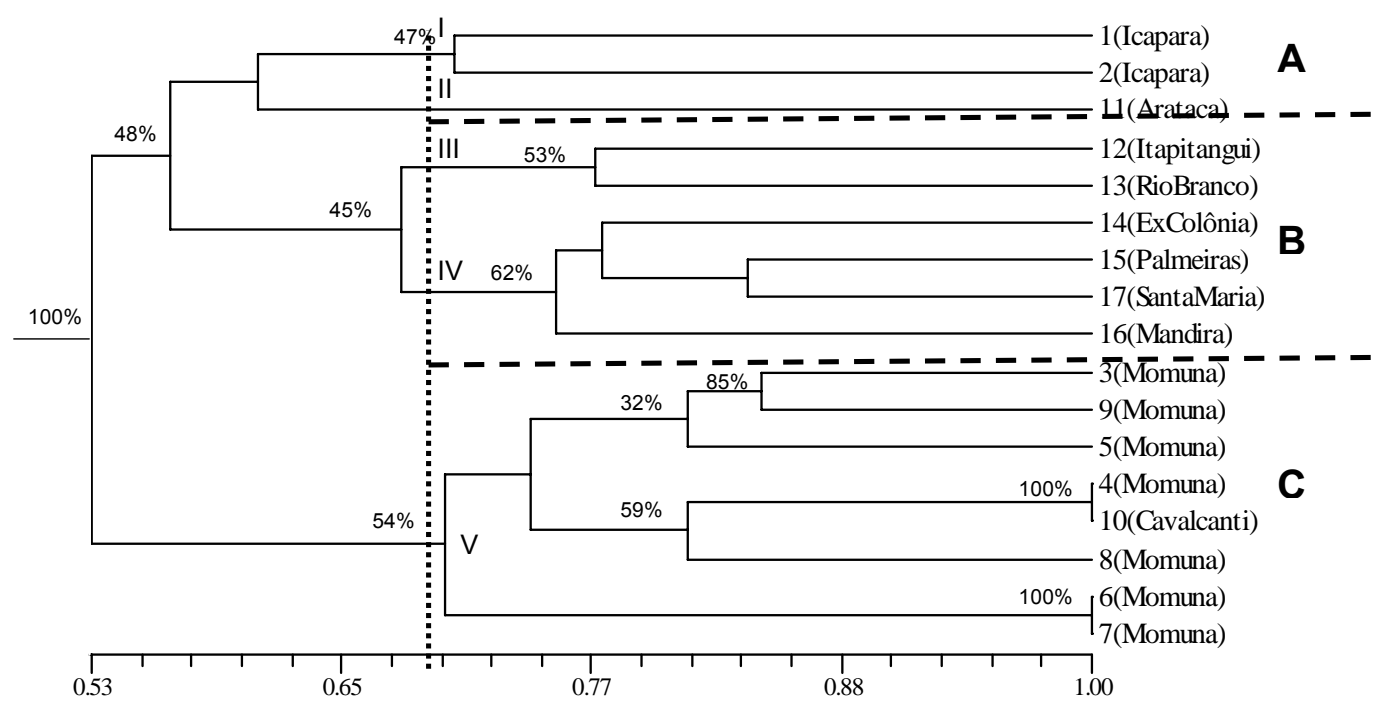

APÊNDICE 3 - Análise de agrupamento pelo método aglomerativo UPGMA relativo a 17 roças que cultivam $D$. trifida, com base em 24 caracteres morfológicos, de acordo com a similaridade do índice de Jaccard. Piracicaba - SP, 2005 


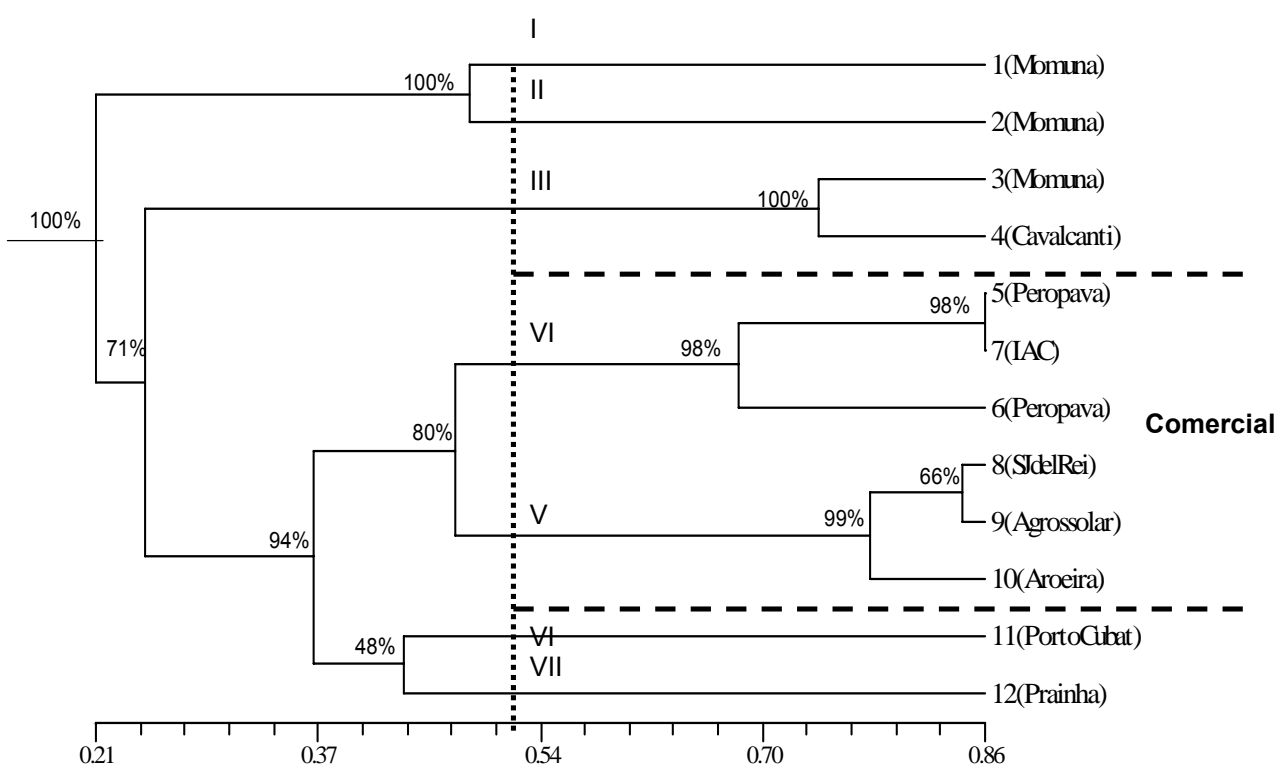

APÊNDICE 4 - Análise de agrupamento pelo método aglomerativo UPGMA relativo a 10 roças e duas localidades que cultivam a espécie $D$. bulbifera, com base em 67 bandas isoenzimáticas, de acordo com a similaridade do índice de Jaccard. Piracicaba - SP, 2005 


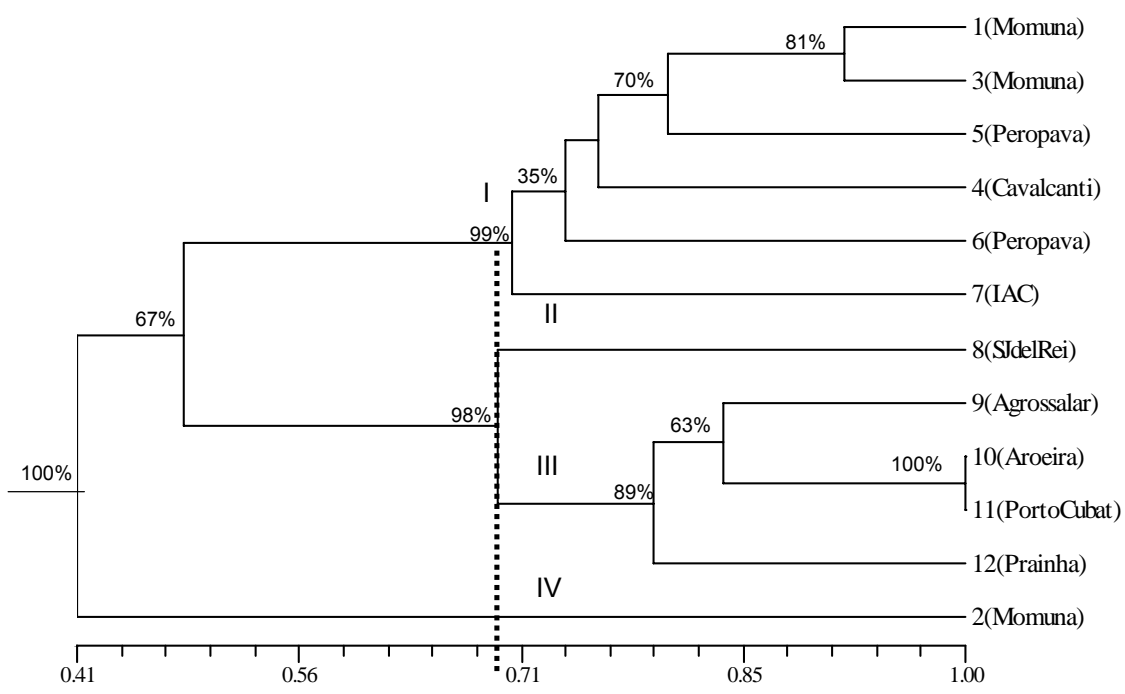

APÊNDICE 5 - Análise de agrupamento pelo método aglomerativo UPGMA relativo a 10 roças e duas localidades que cultivam $D$. bulbifera, com base em 24 caracteres morfológicos, de acordo com a similaridade do índice de Jaccard. Piracicaba - SP, 2005 


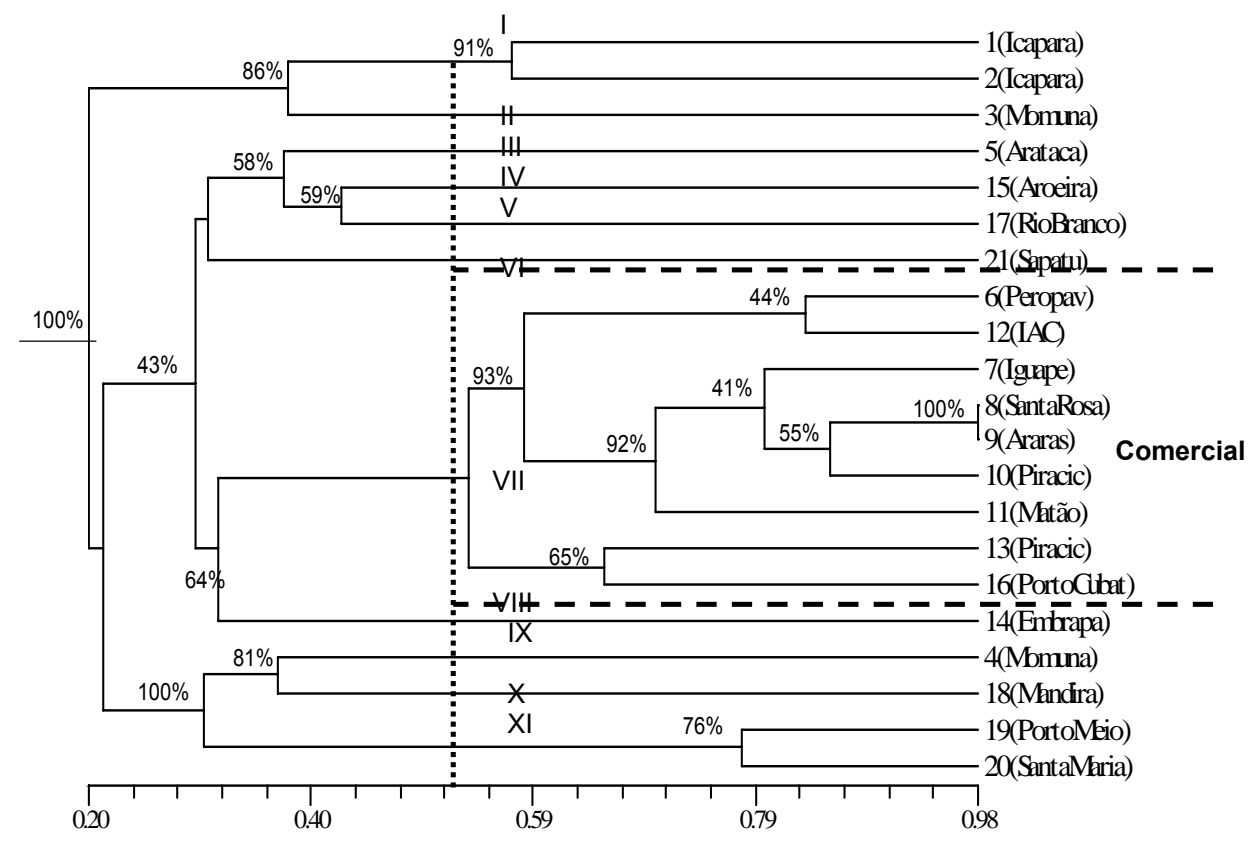

APÊNDICE 6 - Análise de agrupamento pelo método aglomerativo UPGMA relativo a 13 roças e 8 locais de coleta de $D$. alata, com base em 71 bandas isoenzimáticas, de acordo com a similaridade do índice de Jaccard. Piracicaba - SP, 2005 


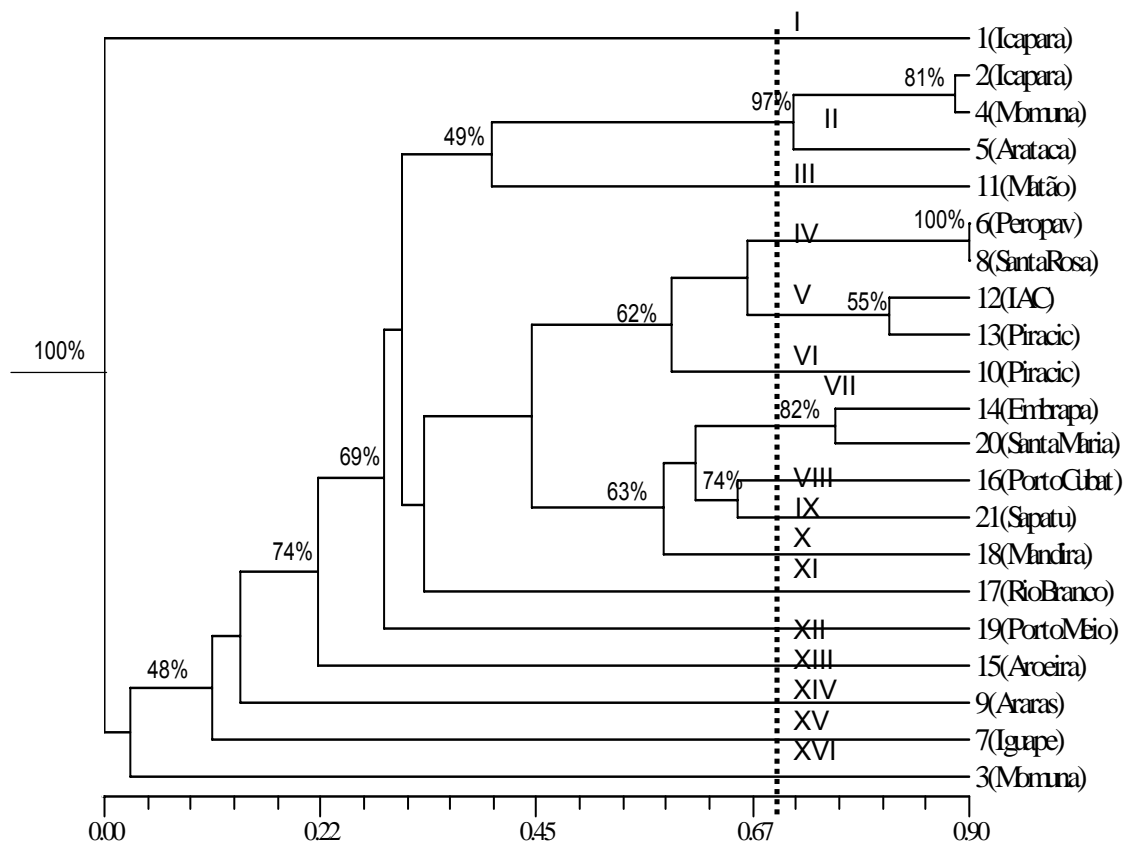

APÊNDICE 7 - Análise de agrupamento pelo método aglomerativo UPGMA relativo a relativo a 13 roças e 8 locais de coleta de $D$. alata, com base em 24 caracteres morfológicos, de acordo com a similaridade do índice de Jaccard. Piracicaba - SP, 2005 


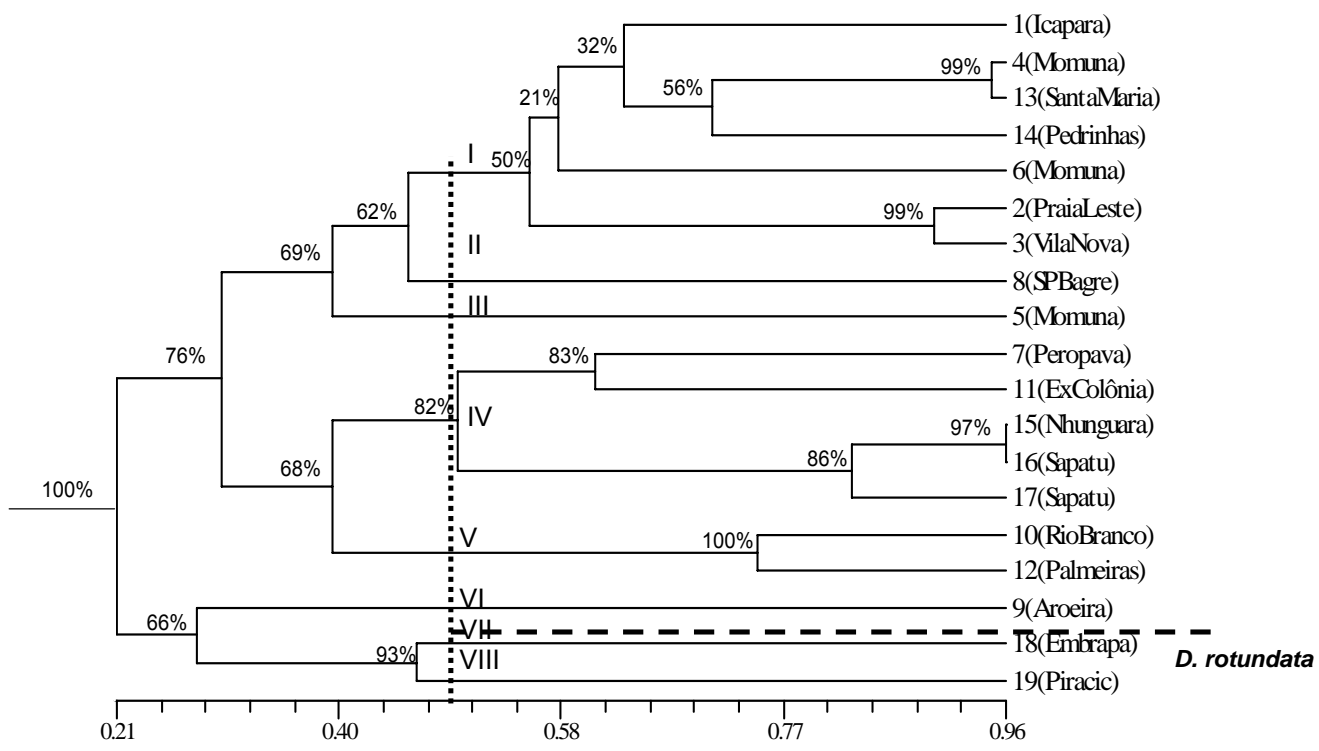

APÊNDICE 8 - Análise de agrupamento pelo método aglomerativo UPGMA relativo a 17 roças que cultivam a espécie $D$. cayenensis e duas locais que cultivam a espécie $D$. rotundata, com base em 65 bandas isoenzimáticas, de acordo com a similaridade do índice de Jaccard. Piracicaba - SP, 2005 


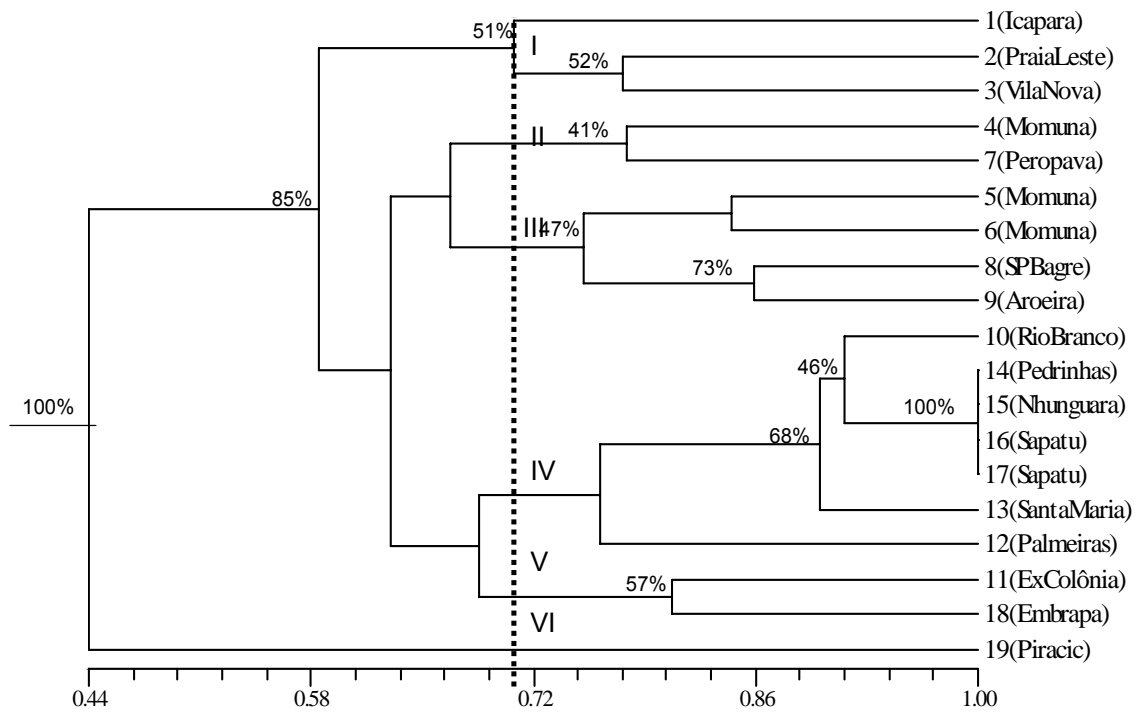

APÊNDICE 9 - Análise de agrupamento pelo método aglomerativo UPGMA relativo a 17 roças que cultivam $D$. cayenensis e duas localidades que cultivam $D$. rotundata, com base em 24 caracteres morfológicos, de acordo com a similaridade do índice de Jaccard. Piracicaba - SP, 2005 